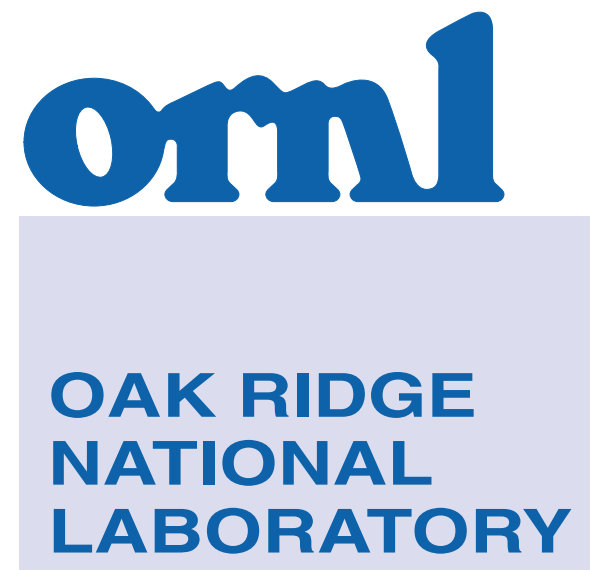

LOC K H EED MA RTIN/7
ORNL/TM-2000/10

\section{Depleted Uranium Storage and Disposal Trade Study: Summary Report}

\author{
J. R. Hightower \\ J. R. Trabalka
}


Chemical Technology Division

\title{
DEPLETED URANIUM STORAGE AND DISPOSAL TRADE STUDY: SUMMARY REPORT
}

\author{
Compilers:
}

J. R. Hightower

J. R. Trabalka

Other Contributors:

D. W. Lee, Energy Division, ORNL

R. L. Reid, Engineering Technology Division, ORNL

W. K. Duerksen

Development Division, Oak Ridge Y-12 Plant

B. M. Biwer, N. L. Ranek, M. Goldberg, and H. I. Avci Environmental Assessment Division Argonne National Laboratory, Argonne, Illinois

February 2000

Prepared by the OAK RIDGE NATIONAL LABORATORY

Oak Ridge, Tennessee 37831-6285

managed by

LOCKHEED MARTIN ENERGY RESEARCH CORP.

for the

U.S. DEPARTMENT OF ENERGY

under contract DE-AC05-96OR22464 


\section{CONTENTS}

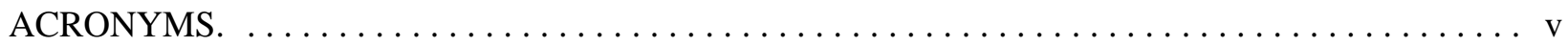

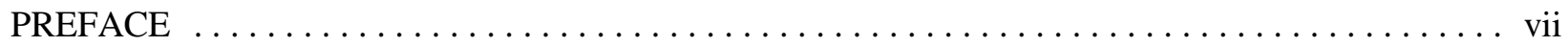

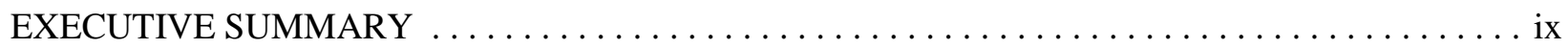

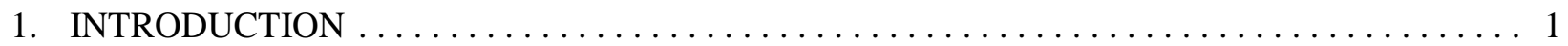

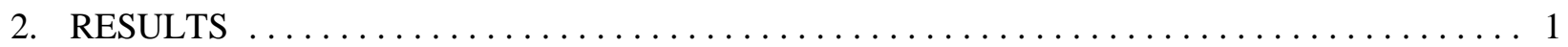

2.1 SIMPLIFIED LIFE-CYCLE COST ANALYSIS $\ldots \ldots \ldots \ldots \ldots \ldots \ldots \ldots \ldots \ldots \ldots$

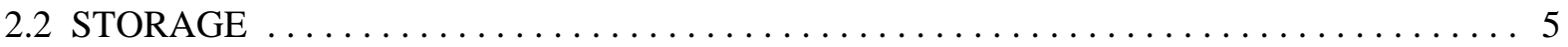

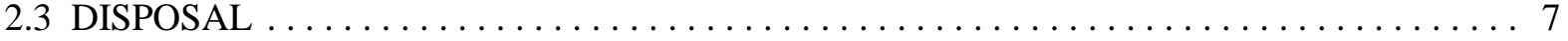

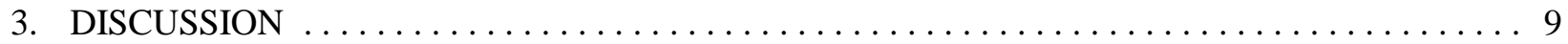

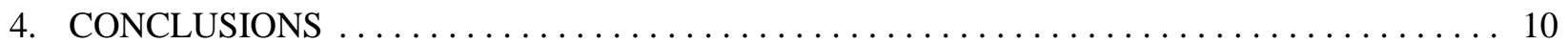

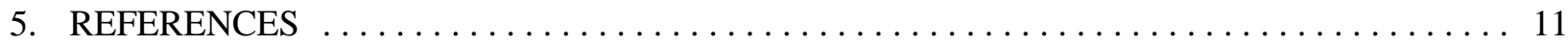

Appendix A. SIMPLIFIED LIFE CYCLE COSTS FOR SELECTED DUF CONVERSION AND MANAGEMENT OPTIONS . . . . . . . . . . . . . A A-1

Appendix B. SELECTION OF OPTIMUM STORAGE FORMS FOR DEPLETED

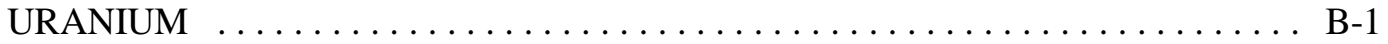

Appendix C. EVALUATION OF DEPLETED URANIUM DISPOSAL $\ldots \ldots \ldots \ldots \ldots \ldots$ C-1

Appendix D. DEPLETED URANIUM DISPOSAL FEASIBILITY ASSESSMENT $\ldots \ldots \ldots$ D-1 


\section{ACRONYMS}

DOE U.S. Department of Energy

DU depleted uranium

DUF $_{6} \quad$ depleted uranium hexafluoride

EIS Environmental Impact Statement

ES\&H environmental, safety, and health

LCC life-cycle cost

LLW low-level radioactive waste

MT metric tons

NEPA National Environmental Policy Act

NRC U.S. Nuclear Regulatory Commission

NTS Nevada Test Site

PEIS Programmatic Environmental Impact Statement

WAC waste acceptance criteria 


\section{PREFACE}

The appendixes to this report are presented substantially as they were submitted by the individual contributors who are identified at the beginning of each appendix.

This report was prepared as an account of work sponsored by an agency of the U.S. government. Neither the U.S. government, any agency thereof, nor any of their employees makes any warranty, express or implied, or assumes any liability or responsibility for the accuracy, completeness, or usefulness of the information, apparatus, product, or process disclosed or represents that its use would not infringe privately owned rights. Reference herein to any specific commercial product, process, or service by trade name, trademark, manufacturer, or otherwise does not necessarily constitute or imply its endorsement, recommendation, or favoring by the U.S. government or any agency thereof. The views and opinions of the authors expressed herein do not necessarily state or reflect those of the U.S. government or any agency thereof. 


\section{EXECUTIVE SUMMARY}

The objectives of this study were to

- identify the most desirable forms for conversion of depleted uranium hexafluoride $\left(\mathrm{DUF}_{6}\right)$ for extended storage,

- identify the most desirable forms for conversion of $\mathrm{DUF}_{6}$ for disposal,

- evaluate the comparative costs for extended storage or disposal of the various forms,

- review benefits of the proposed plasma conversion process,

- estimate simplified life-cycle costs (LCCs) for five scenarios that entail either disposal or beneficial reuse, and

- determine whether an overall optimal form for conversion of $\mathrm{DUF}_{6}$ can be selected given current uncertainty about the endpoints (specific disposal site/technology or reuse options).

\section{Storage}

The questions concerning the optimal forms for storage and disposal cannot be answered in isolation, ignoring the costs and consequences for producing the materials to be stored and disposed or for the ultimate use or disposition. The preferred form for storage of depleted uranium from the point of view of the manager of a storage facility who is looking to optimize his efforts in providing storage services was addressed by reviewing storage experience at operating DOE storage facilities with an emphasis on activities at Y-12. From that perspective, the most desirable forms for extended storage (in terms of storage cost, safety and health, and meeting regulatory issues) follow, in decreasing order of desirability:

\section{Form $\quad$ Comments}

Metal (billet or ingot) Most dense form; requires least floor space; no containment problem

$\mathrm{UO}_{2}$ sintered shapes $\quad$ Very dense stable oxide form; no containment problem

$\mathrm{UO}_{2}$ aggregate forms $\quad$ Dense stable oxide form; no containment problem

$\mathrm{U}_{3} \mathrm{O}_{8}$ powder

Most stable form; must take containment precautions with powders

$\mathrm{UF}_{4}$ powder

Relatively stable form with some reported corrosion problems; containment issues

$\mathrm{UO}_{3}$ powder $\quad$ Fairly dense oxide form, but hygroscopic

$\mathrm{UO}_{2}$ powder Converts to $\mathrm{U}_{3} \mathrm{O}_{8}$ in air with volume change; possibly pyrophoric

\section{Disposal}

Disposal at the Nevada Test Site (NTS) was determined to be the most likely option and, thus, was emphasized in this study. From the results of the analysis, a clear optimal form for disposal (in terms of disposal cost, safety and health, and environmental impact) was not apparent from disposal considerations alone. Most forms of the $\mathrm{DUF}_{6}$ conversion products considered have been disposed of at NTS as low-level waste, but in much smaller quantities than envisioned in this program.

Various difficulties with the disposal of large quantities of conversion products must be addressed. Statements of policy indicate that disposal sites will accept the total production in almost any form, but 
ambiguity exists about the need for further treatment in some cases. Some forms ( $\mathrm{UF}_{4}$ and metal) were not considered for disposal in the Programmatic Environmental Impact Statement (PEIS). In addition, pending National Environmental Policy Act (NEPA) actions for U.S. Department of Energy (DOE) waste management could impact the ability to dispose of such material at NTS.

The forms considered for disposal are as follows:

\begin{tabular}{|c|c|}
\hline Form & $\underline{\text { Comments }}$ \\
\hline $\mathrm{U}_{3} \mathrm{O}_{8}$ powder & $\begin{array}{l}\text { Most stable; meets NTS waste acceptance criteria (WAC) with no } \\
\text { treatment; analyzed in the PEIS }\end{array}$ \\
\hline $\mathrm{UF}_{4}$ powder & $\begin{array}{l}\text { Relatively stable; meets land disposal restrictions and NTS WAC with } \\
\text { no treatment; } 5000 \text { metric tons (MT) disposed of at NTS; not analyzed } \\
\text { in PEIS }\end{array}$ \\
\hline $\begin{array}{l}\mathrm{UO}_{2} \text { aggregate forms and } \\
\text { sintered shapes }\end{array}$ & $\begin{array}{l}\text { Very stable and low porosity; does not meet density WAC, but the U.S. } \\
\text { Nuclear Regulatory Commission prefers these forms due to low } \\
\text { permeability to water }\end{array}$ \\
\hline $\mathrm{UO}_{3}$ powder & 25 MT disposed of at NTS \\
\hline Metal & $\begin{array}{l}\text { Not analyzed in PEIS; some macroencapsulated metal shapes disposed } \\
\text { of at NTS }\end{array}$ \\
\hline $\mathrm{UO}_{2}$ powder & Potentially pyrophoric unless treated \\
\hline
\end{tabular}

The following actions must be completed before disposal at NTS can be accomplished:

1. Initiate negotiations with the Waste Management Organization at DOE/Nevada to

a. evaluate whether the depleted uranium (DU) should be targeted for Area 3 or Area 5 at NTS,

b. evaluate the need to increase NTS disposal capacity to accommodate the large quantities of DU forms to be disposed of, and

c. review waste streams (product forms) and characteristics and evaluate the ability to meet the WAC directly or to develop the necessary justification for exemptions.

2. Initiate the process to achieve approved shipper status to NTS.

3. Complete the existing NEPA documentation for the NTS and DOE Waste Management Environmental Impact Statement, and initiate the additional NEPA documentation required for disposal of all DUF 6 conversion alternatives.

\section{Overall}

A simplified LCC analysis was performed for several scenarios to help determine the most effective conversion form. The scenarios can be summarized as follows:

1. conversion to $\mathrm{U}_{3} \mathrm{O}_{8}$ and disposal in shallow-land burial trenches at the NTS;

2. conversion to metal, disposal as in scenario 1 ;

3. conversion to $\mathrm{UF}_{4}$, disposal as in scenario 1 ;

4. conversion to $\mathrm{U}_{3} \mathrm{O}_{8}$, secondary conversion to $\mathrm{UO}_{2}$ and metal, and beneficial reuse in the form of either storage casks $\left(\mathrm{UO}_{2}\right)$ or multipurpose shields (metal) for spent nuclear fuel; 
5. conversion to metal, secondary conversion of half of the metal to $\mathrm{UO}_{2}$, and beneficial reuse as in scenario 4;

6. conversion to $\mathrm{UF}_{4}$, secondary conversion to $\mathrm{UO}_{2}$ and metal, and beneficial reuse as in scenario 4; and

7. conversion to a mixture of $\mathrm{U}_{3} \mathrm{O}_{8}$ and metal, secondary conversion of the $\mathrm{U}_{3} \mathrm{O}_{8}$ to $\mathrm{UO}_{2}$, and beneficial reuse as in scenario 4.

The most significant observations from these cost analyses are as follows:

- Conversion to $\mathrm{UF}_{4}$ followed by disposal has the lowest LCC of all scenarios investigated.

- Conversion to $\mathrm{UF}_{4}$ followed by beneficial reuse as oxide and metal has the lowest LCC for converting to an intermediate form by using conventional technologies.

- The costs of conversion to $\mathrm{UF}_{4}$ followed by beneficial reuse as oxide and metal are comparable to those for direct conversion to a mixture of oxide and metal by using conventional technologies.

- Significant storage costs may be avoided by considering the potential for using dedicated shallowland trenches at a disposal site for both storage and disposal. The feasibility of doing this should be investigated.

In considering the preceding components of analysis, LCC is the most important determinant as long as the product is acceptable. Therefore, it is felt that the three most promising chemical forms of uranium into which to convert the depleted $\mathrm{UF}_{6}$ are the following (in order of preference):

- $\mathrm{UF}_{4}$

- Based on current experience, this form has acceptable stability and compatibility with extended storage.

- Conversion to $\mathrm{UF}_{4}$ has the lowest estimated LCC (for conversion, storage, and disposal).

- This form provides the highest flexibility in reuse (as an intermediate in conversion to either $\mathrm{UO}_{2}$ or metal).

- The environmental impacts of disposal of $\mathrm{UF}_{4}$ were not analyzed in the PEIS, however.

- $\mathrm{U}_{3} \mathrm{O}_{8}$

- This form has high stability and compatibility with long-term storage.

- The LCC (conversion, storage, and disposal) is about $80 \%$ higher than that for $\mathrm{UF}_{4}$.

- This form has the lowest compatibility with reuse (of the three options listed here).

- This form was analyzed in the PEIS.

- Compacted forms of $\mathrm{UO}_{2}$

- These forms have the highest compatibility with long-term storage (containment).

- The LCC is somewhat higher than that for $\mathrm{U}_{3} \mathrm{O}_{8}$ (conversion, storage, and disposal) because of additional sintering/compaction costs.

- These forms have good compatibility with high-priority reuse options.

- These forms were analyzed in the PEIS. 


\section{INTRODUCTION}

The objective of this trade study was to address the following questions:

- What are the most desirable forms for extended storage of DU?

- Is R\&D needed to develop the technical basis for a DU storage standard?

- What are the most desirable forms for disposal of DU? Is the disposal of DU metal feasible, and, if so, what steps must be taken to achieve this outcome?

- What are the comparative costs for extended storage or disposal of the various forms?

- Can an overall optimal form for storage of DU be selected given current uncertainty about the endpoints (specific disposal site/technology or reuse options)?

The questions concerning the optimal forms for storage and disposal cannot be answered in isolation, ignoring the costs and consequences for producing the materials to be stored and disposed or the ultimate use or disposition. Thus, the impacts of differences in assumptions about potential conversion technologies, products, and endpoints on an overall optimal form in which to convert depleted $\mathrm{UF}_{6}$ were addressed by developing simplified life cycle costs for seven scenarios which entailed either disposal or beneficial reuse.

The results of the study are summarized in this document with detailed analyses provided in the appendixes.

\section{RESULTS}

\subsection{SIMPLIFIED LIFE-CYCLE COST ANALYSIS}

Simplified LCCs were developed for 11 combinations (options) of selected DU conversion technologies (conventional vs experimental), primary conversion products $\left(\mathrm{U}_{3} \mathrm{O}_{8}\right.$ and/or metal, or $\left.\mathrm{UF}_{4}\right)$, and long-term management options (disposal or beneficial reuse) based on the following seven scenarios (see Appendix A):

1. conversion to $\mathrm{U}_{3} \mathrm{O}_{8}$ and disposal in shallow-land burial trenches at the Nevada Test Site (NTS);

2. conversion to metal, disposal as in scenario 1 ;

3. conversion to $\mathrm{UF}_{4}$, disposal as in scenario 1 ;

4. conversion to $\mathrm{U}_{3} \mathrm{O}_{8}$, secondary conversion to $\mathrm{UO}_{2}$ and metal, and beneficial reuse in the form of either storage casks $\left(\mathrm{UO}_{2}\right)$ or multipurpose shields (metal) for spent nuclear fuel;

5. conversion to metal, secondary conversion of half of the metal to $\mathrm{UO}_{2}$, and beneficial reuse as in scenario 4;

6. conversion to $\mathrm{UF}_{4}$, secondary conversion to $\mathrm{UO}_{2}$ and metal, and beneficial reuse as in scenario 4; and

7. conversion to a mix of $\mathrm{U}_{3} \mathrm{O}_{8}$ and metal, secondary conversion of the $\mathrm{U}_{3} \mathrm{O}_{8}$ to $\mathrm{UO}_{2}$, and beneficial reuse as in scenario 4.

Options 2, 4, 5, and 7 were examined assuming that conversion to metal was accomplished with (1) conventional metallothermic conversion technology and (2) a hypothetical new conversion technology that has economics comparable to those of technologies for conversion to $\mathrm{U}_{3} \mathrm{O}_{8}$ and produces elemental 
$\mathrm{F}_{2}$ as the fluorine-containing by-product. These options have been designated as $2 \mathrm{p}, 4 \mathrm{p}, 5 \mathrm{p}$, and $7 \mathrm{p}$ in the analysis and discussion.

Although conversion forms other than oxide or metal were elimated from serious consideration in the screening of alternatives for the final Programmatic Environmental Impact Statement (PEIS) (DOE 1999), several $\mathrm{UF}_{4}$ conversion scenarios were included in the current study because recent information has suggested that conversion to $\mathrm{UF}_{4}$ could potentially decrease conversion and storage costs, as well as increase flexibility in the reuse of DU.

For the purposes of simplification, all scenarios were based on conversion of the depleted uranium hexafluoride $\left(\mathrm{DUF}_{6}\right)$ inventory - 450,000 metric tons $(\mathrm{MT})$ - at the Paducah Gaseous Diffusion Plant (PGDP) only. By considering at only this plant, existing cost data could be used directly, scaling problems could be eliminated, and the points of comparison would still be valid. These LCC values should not be construed to be those for managing the entire U.S. Department of Energy (DOE) $\mathrm{UF}_{6}$ inventory. In addition, costs common to all scenarios were omitted. A 7-year period of interim storage was incorporated into each scenario between primary conversion and disposal, secondary conversion for reuse, or reuse without secondary conversion to reflect the contemporary plans for a proposed procurement action. The beneficial reuse scenarios (3-5 and 7) assume that equal amounts of DU are used, respectively, in the fabrication of (1) concrete storage casks and (2) multipurpose shields for storage, transportation, and/or disposal of spent nuclear fuel. Revenues from such uses are used to reduce the net LCCs of these options. Potential revenues from the sale of anhydrous HF were also used to offset conversion costs in all of the scenarios considered (see Appendix A for details).

The reference cases for scenarios 2, 5, and 7 (labeled options 2, 5, and 7), which require primary conversion to metal, were based on the use of the commercial two-step reduction process utilizing magnesium. The analysis was then repeated by incorporating assumed advantages for a hypothetical single-step conversion process (labeled options $2 \mathrm{p}, 5 \mathrm{p}$, and $7 \mathrm{p}$, respectively). In option $4 \mathrm{p}$, it was assumed that secondary conversion of half of the $\mathrm{U}_{3} \mathrm{O}_{8}$ product for reuse as metal would be performed by substituting the plasma process for the conventional process used in option 4.

Simplified LCC comparisons based on the existing state-of-the-art processes for converting DUF $\mathrm{D}_{6}$ to oxide, $\mathrm{UF}_{4}$, or metal (Table 1; also see Appendix A) lead to the following observations:

- Option 3 (conversion to $\mathrm{UF}_{4}$, storage, and disposal) had the lowest total LCC $(\$ 514 \mathrm{M})$ of the 11 options considered because it (and option 6) had the lowest primary conversion cost (\$207M)—about one-third of that for option 1. The low costs result from the elimination of more rigorous and costly pyrohydrolysis or metallothermic reduction steps from the initial conversion activity. The LCC for option 3 is about $56 \%$ of that for option 1 (conversion to $\mathrm{U}_{3} \mathrm{O}_{8}$ ).

- Modifying option 3 to eliminate the 7-year interim storage step before disposal reduces the LCC of option 3 by $\$ 140 \mathrm{M}$ (or $27 \%$ ).

- The LCC for option 1 is about half that for option 2 (conversion to uranium metal), reflecting the high metal conversion costs using conventional technology.

- Primary conversion to $\mathrm{UO}_{2}$ rather than $\mathrm{U}_{3} \mathrm{O}_{8}$ is estimated to increase the LCC of option 1 by $\$ 151 \mathrm{M}$, or $17 \%$ (see costs for secondary conversion of $\mathrm{U}_{3} \mathrm{O}_{8}$ to $\mathrm{UO}_{2}$ in Table 6 of Appendix A).

- Converting $\mathrm{DUF}_{6}$ to $\mathrm{U}_{3} \mathrm{O}_{8}$, uranium metal, or a combination of the two, followed by storage and beneficial reuse in casks or shields for spent fuel (options 4-7), is two to three times more costly ( $\$ 2214 \mathrm{M}-\$ 2629 \mathrm{M})$ than option 1, leading to disposal of $\mathrm{U}_{3} \mathrm{O}_{8}$. 
- Option 7, in which $\mathrm{DUF}_{6}$ is directly converted to the assumed form of use $\left(\mathrm{U}_{3} \mathrm{O}_{8}\right.$ and uranium metal), has the lowest LCC of the "beneficial reuse" options that utilize conventional conversion technologies. This illustrates the value of knowing the final disposition before initiating conversion.

- The simplified LCC estimate for beneficial reuse option $6(\$ 2274 \mathrm{M})$ is higher than the LCCs for the corresponding advanced metal conversion options (\$1610M-\$2015M) but falls within the range those $(\$ 2214 \mathrm{M}-\$ 2629 \mathrm{M})$ for beneficial reuse options based on conventional technologies for conversion to metal/oxide. The simplified LCC for option 6 is only $\$ 60 \mathrm{M}$ greater than that for option 7 (two half-size plants producing $\mathrm{U}_{3} \mathrm{O}_{8}$ and uranium metal by conventional processes, followed by storage and beneficial use), although it is $\$ 570 \mathrm{M}$ higher than that for option $7 \mathrm{p}$ (in which DUF $_{6}$ is assumed to be converted to metal via the hypothetical process, followed by interim storage and subsequent reuse).

- The LCC for beneficial reuse in option 6 (Table 1) reflects residual costs for secondary conversion that are higher than those for any other alternative considered (see Appendix A). This situation occurs because more rigorous and costly steps needed to complete the conversion to an oxide or metal were deferred from the initial conversion activity to the beneficial reuse activity. However, the difference between overall LCCs for option 6 and option 7 is small, indicating only a small penalty for selecting $\mathrm{UF}_{4}$ as an intermediate conversion product even if other final-use products are selected.

Assuming the feasibility of a new process to produce metal and incorporating its assumed advantages into the simplified LCC analysis yielded the following results (Table 1; also see Appendix A):

- Option 2p, in which $\mathrm{DUF}_{6}$ is converted to uranium metal via the new process, has a simplified LCC $(\$ 763 \mathrm{M})$ that is intermediate between that for option $1(\$ 915 \mathrm{M})$, conversion to $\mathrm{U}_{3} \mathrm{O}_{8}$ via conventional means, and option $3(\$ 514 \mathrm{M})$, conversion to $\mathrm{UF}_{4}$. The simplified LCC for option $2 \mathrm{p}$ is about $20 \%$ less than that for option 1 but nearly $50 \%$ higher than that for option 3 . The difference in the LCCs of options 1 and $2 p$ is decreased to $8 \%$ if the interim storage step is eliminated from scenario 1 (i.e., if the DU productis disposed of as it is produced).

- Conversion of $\mathrm{DUF}_{6}$ to $\mathrm{U}_{3} \mathrm{O}_{8}$, uranium metal, or some combination of the two, followed by storage and beneficial reuse in casks or shields for spent fuel (options $3 p-5 p$ ), is two to three times more costly $(\$ 1610 \mathrm{M}-\$ 2015 \mathrm{M})$ than option $2 \mathrm{p}$, leading to the disposal of uranium metal.

- Option 5p, in which $\mathrm{DUF}_{6}$ is first converted to uranium metal via a new metal process and then is partially converted to $\mathrm{UO}_{2}$ for reuse as a mix of $\mathrm{UO}_{2}$ and metal, has the lowest simplified LCC of any of the beneficial reuse options. The LCC difference between options $5 p$ and $7 p$ is principally due to storage and container savings, with a larger quantity of metal produced in option $5 \mathrm{p}$.

Conclusions that appear to apply regardless of assumptions about conversion forms or technologies (see data in Table 1) can be summarized as follows:

- The costs of primary conversion and/or of fabrication for reuse (including secondary conversion needed to permit reuse) are the largest individual contributors to LCCs. High costs for secondary conversion in the beneficial reuse options argue against selection of a single storage form for the DU product until options for reuse are better defined.

- Costs for the interim storage of $\mathrm{U}_{3} \mathrm{O}_{8}, \mathrm{UF}_{4}$, and uranium metal are three to eight times those for disposal, assuming that shallow-land burial of these materials at the NTS is feasible without the need for additional treatment.

- Storage of low-density $\mathrm{U}_{3} \mathrm{O}_{8}$ or $\mathrm{UF}_{4}$ is more costly than that for high-density uranium metal by about a factor of 3 (but see the discussion below, and in Folga et al. 1999a, 1999b). However, the cost 
Table 1. Life cycle costs $\left(\$ 10^{6}\right)$ for selected $\mathrm{DU}^{a}$ conversion forms and management options ${ }^{b}$

\begin{tabular}{|c|c|c|c|c|c|c|c|c|c|c|c|}
\hline \multirow[b]{2}{*}{ Cost category } & \multicolumn{4}{|c|}{ Disposal options $^{c}$} & \multicolumn{7}{|c|}{ Reuse (as 1:1 mixture of $\mathrm{UO}_{2}$ and metal) options ${ }^{c}$} \\
\hline & $\begin{array}{c}1 \\
\left(\mathrm{U}_{3} \mathrm{O}_{8}\right)\end{array}$ & $\begin{array}{c}2 \\
\text { (Metal) }\end{array}$ & $\begin{array}{c}2 \mathrm{p}^{d} \\
\text { (Metal) }\end{array}$ & $\begin{array}{c}3 \\
\left(\mathrm{UF}_{4}\right)\end{array}$ & $\begin{array}{c}4 \\
\left(\mathrm{U}_{3} \mathrm{O}_{8}\right)\end{array}$ & $\begin{array}{c}4 \mathrm{p}^{d} \\
\left(\mathrm{U}_{3} \mathrm{O}_{8}\right)\end{array}$ & $\begin{array}{c}5 \\
\text { (Metal) }\end{array}$ & $\begin{array}{c}5 \mathrm{p}^{d} \\
\text { (Metal) }\end{array}$ & $\begin{array}{c}6 \\
\left(\mathrm{UF}_{4}\right)\end{array}$ & $\begin{array}{c}7 \\
\left(\mathrm{U}_{3} \mathrm{O}_{8}+\right. \\
\text { metal })\end{array}$ & $\begin{array}{c}7 \mathrm{p}^{d} \\
\left(\mathrm{U}_{3} \mathrm{O}_{8}+\right. \\
\text { metal })\end{array}$ \\
\hline Conversion & 587 & 1537 & 587 & 207 & 587 & 587 & 1537 & 587 & 207 & 1062 & 587 \\
\hline \multicolumn{12}{|l|}{ Containers } \\
\hline DU & 57 & 38 & 38 & 64 & 57 & 57 & 38 & 38 & 64 & 48 & 48 \\
\hline Other & 6 & 36 & 8 & 0 & 6 & 6 & 36 & 8 & 20 & 21 & 7 \\
\hline Subtotal & 63 & 74 & 46 & 64 & 63 & 63 & 74 & 46 & 84 & $68^{e}$ & 55 \\
\hline $\begin{array}{l}\text { 7-year DU } \\
\text { product storage }\end{array}$ & 140 & 47 & 47 & 137 & 140 & 140 & 47 & 47 & 137 & 132 & 132 \\
\hline Beneficial reuse $^{f}$ & NA & NA & NA & NA & 1665 & 1190 & 896 & 896 & 1797 & 896 & 896 \\
\hline \multicolumn{12}{|l|}{ Transportation } \\
\hline DU & 54 & 43 & 43 & 59 & 0 & 0 & 0 & 0 & 0 & 0 & 0 \\
\hline Other & 31 & 52 & 28 & 6 & 31 & 31 & 52 & 28 & 36 & 42 & 41 \\
\hline Subtotal & 85 & 95 & 71 & 65 & 31 & 31 & 52 & 28 & 36 & 42 & 41 \\
\hline \multicolumn{12}{|l|}{ Disposal } \\
\hline DU & 36 & 6 & 6 & 40 & 0 & 0 & 0 & 0 & 0 & 0 & 0 \\
\hline Other & 4 & 23 & 5 & 0 & 4 & 4 & 23 & 6 & 13 & 13 & 4 \\
\hline Subtotal & 40 & 29 & $12^{e}$ & 40 & 4 & 4 & 23 & 6 & 13 & 13 & 4 \\
\hline Grand total & 915 & 1781 & 763 & 514 & 2490 & 2015 & 2629 & 1610 & 2274 & 2214 & 1704 \\
\hline
\end{tabular}

${ }^{a} \mathrm{DU}=$ depleted uranium

${ }^{b}$ Source: Appendix A (Tables 1-9).

${ }^{c}$ Conversion forms are shown in parentheses.

${ }^{d}$ Assumes that (1) a hypothetical new technology for conversion of DUF 6 to metal will be developed and implemented successfully and (2)

conversion costs will be equivalent to those for production of $\mathrm{U}_{3} \mathrm{O}_{8}$ using conventional technology (see text).

${ }^{e}$ Subtotals do not match totals of addends because of rounding errors.

${ }^{f}$ Includes costs for secondary conversion of $\mathrm{U}_{3} \mathrm{O}_{8}$ to $\mathrm{UO}_{2}$ or metal and/or uranium metal to $\mathrm{UO}_{2}$, as appropriate (see text). 
differential contributes $\leq 16 \%$ of the summed LCCs for the conversion, containers, and storage cost categories.

- Revenues provided by the beneficial reusage considered in the simplified LCC exercise were not sufficient to offset the costs of secondary conversion and/or fabrication for reuse. Subtracting the simplified LCCs for options 1, 2p, and 3 from the LCCs for the corresponding beneficial reuse options leaves residual costs that range from $\$ 1299 \mathrm{M}-\$ 1760 \mathrm{M}$ and from $\$ 847 \mathrm{M}-\$ 1252 \mathrm{M}$, respectively, for options that utilize conventional or advanced conversion technologies. If interim storage costs are eliminated from options 1,2p, and 3, the residual LCCs for the two categories of beneficial reuse options increase to $\$ 1439 \mathrm{M}-\$ 1897 \mathrm{M}$ and $\$ 894 \mathrm{M}-\$ 1299 \mathrm{M}$, respectively.

Caution should be exercised in interpreting the significance of the cost comparisons from the simplified LLC exercise because of the following considerations:

- More-detailed analyses could alter the conclusions significantly for important cost categories. Information for advanced conversion to metal, conversion to $\mathrm{UF}_{4}$, and secondary conversion, in general, was quite limited-leading to a more simplified analysis of these components of LCCs, in particular. A more-detailed preconceptual design exercise produced LCCs for long-term storage of uranium metal that were similar to those for storage of the oxides (Folga et al. 1999a, 1999b) - in direct contrast to the results from the simplified LCC analysis.

- Costs were developed for only one disposal scenario, that is, direct disposal at NTS of containerized, untreated $\mathrm{U}_{3} \mathrm{O}_{8}, \mathrm{UF}_{4}$, or uranium metal. Costs associated with other alternatives could be somewhat lower (shallow-land burial in bulk form) or very much higher (isolation of treated wastes in an engineered repository). Much higher costs for disposal could make the economics of reuse more attractive.

- Credits (offsets) for costs avoided by users who substitute DU-containing casks and shields for conventional alternatives were also not considered.

- The roadmapping activity has tentatively identified several technological options that could greatly enhance the economic advantages of reuse. The most promising candidates identified thus far (with further barrier reduction activities recommended) utilize $\mathrm{UO}_{2}$. However, additional R\&D and/or engineering evaluations will be required to assess the potential feasibility and utility of the candidates identified thus far.

\subsection{STORAGE}

The question that has been addressed in this section of the report is to determine the optimal form of depleted uranium for storage in terms of regulatory requirements, cost, and safety and health factors:

- Base analysis of a review of applicable regulations, laws, studies, standards, acceptance criteria (commerial and DOE) and plans.

- What are the possible storage forms (consider $\mathrm{U}_{3} \mathrm{O}_{8}, \mathrm{UO}_{2}$, uranium metal, and other forms)?

- What are the required storage forms?

These questions were addressed by reviewing current DOE uranium storage practice, experience, and standards emphasizing practices at the Y-12 plant.

A wide range of potential physicochemical forms could be considered for extended storage of DU. The choice of form depends, however, on consideration of many factors, which include chemical and physical 
hazards, ES\&H requirements, engineering constraints, operational experience with storage, ability to move from storage to direct reuse without secondary conversion, ability to move from storage to direct disposal without secondary conversion or waste treatment, ease of conversion to secondary forms suitable for reuse or disposal, and potential costs for primary conversion to and storage of the various forms.

Costs for storage of the various forms can be developed independently using standardized assumptions, but these are not particularly meaningful unless they are evaluated in the context of the ultimate endpoint, including overall LCCs. Thus the selection of a storage form cannot be divorced from the selection of an endpoint of the life cycle (type of reuse or disposal site/technology).

Potential forms for storage of converted $\mathrm{DUF}_{6}$ include $\mathrm{UF}_{4}$; uranium metal or its alloys; oxides $\left(\mathrm{UO}_{2}\right.$, $\mathrm{UO}_{3}$, or $\mathrm{U}_{3} \mathrm{O}_{8}$ ); hydrated oxides, silicates, or hydrated silicates (synthetic versions of natural minerals, such as schoepite, soddyite, and uranophane); encapsulated metal; and concrete or grout incorporating uranium oxides.

The consideration of ES\&H and engineering requirements for storage makes $\mathrm{UF}_{4}$ (solubility and reactivity) and $\mathrm{UO}_{3}$ (hygroscopic behavior) less desirable as forms for storage and limits the physical forms in which uranium metal and $\mathrm{UO}_{2}$ can be stored safely. The pyrophoric behavior of uranium metal powders, fines, and chips or of fine $\mathrm{UO}_{2}$ powders makes long-term storage of these forms undesirable. Most of the common alloys behave similarly to uranium metal, but alloys with niobium or zirconium become reactive when treated with nitric acid before being stored (see Appendix B).

Conversion of DUF 6 to synthetic forms of natural minerals was eliminated from formal consideration in the final PEIS because conversion processes had not been developed for these forms and their suitability for storage or disposal had not been sufficiently examined (DOE 1999). The lower densities of hydrated oxides, silicates, and hydrated silicates as compared with the oxides would result in increased storage volumes, with attendant increases in capital and operational costs for storage facilities. Although such forms might be advantageous for direct disposal under certain conditions (see, e.g., Forsberg 1997), costs for beneficial reuse would be increased because of the increased rigor involved in reconversion to a form (i.e., metal or oxide) compatible with reuse. Because it is not clear at this point whether such forms are either needed or desired for disposal, their selection at the outset would result in considerable loss of flexibility in long-term management.

Similar considerations would be invoked in arguments against the storage of converted DU as encapsulated metal or as the grouted oxides.

The questions listed at the beginning of this section ask for a preferred form for storage of depleted uranium from the point of view of the manager of a storage facility who is looking to optimize his efforts in providing storage services. Such an optimum ignores the costs and consequences for producing the materials to be stored or for the ultimate use or disposition.

In this context, in order of decreasing preference, the most desirable forms for long-term storage of DU (see Appendix B) are considered to be

- large cast billets of uranium metal or its stable alloys,

- $\mathrm{U}_{3} \mathrm{O}_{8}$ (containerized to prevent airborne dispersal), and

- $\mathrm{UO}_{2}$ that has been sintered into a ceramic form-either a monolith or a containerized aggregate. 
The consideration of primary conversion costs (Appendix A) favors storage of DU as either uranium metal billets (if plasma conversion proves to be feasible and cost effective) or containerized $\mathrm{U}_{3} \mathrm{O}_{8}$. The alloying of uranium impedes reuse as either uranium metal or $\mathrm{UO}_{2}$ because of the increased complexity and rigor associated with reconversion to the latter forms. However, if a DU metal alloy can be certified for use in shields for spent fuel--and this use proves to be cost-effective-an $11 \%$ weight reduction in storage casks could potentially be achieved (DOE 1995). Under such conditions, storage of the appropriate alloy rather than uranium metal might be considered. Based on current information, however, such a choice does not appear to be cost-effective.

Information presently available on technical feasibility and costs favors conversion to $\mathrm{U}_{3} \mathrm{O}_{8}$ when the selection is limited to those forms considered most desirable for storage. An additional premium is involved in the primary conversion of $\mathrm{DUF}_{6}$ to uranium metal or to a $\mathrm{UO}_{2}$ ceramic, when compared with the production of $\mathrm{U}_{3} \mathrm{O}_{8}$ (powder). However, paying this premium might be considered worthwhile if costs for the secondary conversion to uranium metal are decreased (assuming that there is a need for metal) or if improved stability of an oxide waste form is required (see Sect. 2.4). Conversion-cost issues aside, storage of $\mathrm{UO}_{2}$ in the form of ceramic monoliths or large aggregates (other than pellet-sized material) could increase the costs associated with some beneficial reuses or treatment for disposal. Size reduction of the larger ceramic forms would likely be needed for incorporation of $\mathrm{UO}_{2}$ into concrete for storage casks, conversion to grout formulations designed to produce an improved waste form, or use as repository waste package fill material.

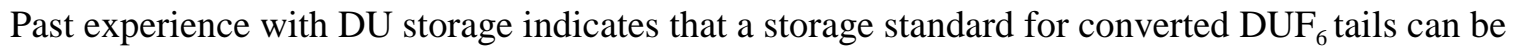
developed without a significant R\&D effort (see Appendix B). Background information useful for development of a storage standard is provided in Sects. 3.4 and 4.2 of Appendix B.

\subsection{DISPOSAL}

Although DU would be classified as a low-level radioactive waste (LLW), the DU forms considered most desirable for storage prior to beneficial reuse (oxides or uranium metal) may not be acceptable for disposal via shallow-land burial without some form of stabilization or treatment or other waste management alternative (see Appendixes $\mathrm{C}$ and D). Thus, a DU form optimal for both storage and disposal cannot be defined precisely at present.

The preceding conclusion currently applies regardless of whether a DOE site or a commercial facility is selected as the disposal location. However, disposal at a commercial facility is considered more problematic than disposal at a DOE site. Thus, a DOE site is favored.

Because of environmental impacts, a dry site, such as Hanford or NTS, is preferred for the following reasons:

- The U.S. Nuclear Regulatory Commission (NRC) has expressed reservations about shallow-land disposal in 10 CFR 61 disposal facilities of large quantities of DU in humid environments because of the potential impacts of radiological and chemical toxicity factors.

- Environmental impacts of shallow-land burial at an arid or semiarid site are expected to be minimal (see Appendix D). However, the millennial-scale analyses of radiological impacts of shallow-land burial of DU do not take into account the long-term buildup of radon from decay of ${ }^{238} \mathrm{U}$. (This factor was not included in the analyses because the equilibration of ${ }^{238} \mathrm{U}$ with its decay products 
occurs on a timescale of about $10^{6}$ years.) Of course, the approach to radiological impact assessment may necessarily become an issue because the scale of projected DU disposals (up to 480,000 MT) is unprecedented.

The facility with the highest current potential for shallow-land disposal of DU is thought to be the NTS because it has the available capacity (land area) to dispose of the entire inventory of converted DUF . $_{\text {. }}$ Moreover, based on past experience, its waste acceptance criteria (WAC) appear to provide the best opportunity for disposal without additional stabilization or treatment (Appendixes C and D).

However, none of the alternative technologies currently proposed for conversion of DUF 6 guarantee a waste form that meets all current criteria for acceptance for disposal without (1) some form of stabilization or treatment to produce an acceptable waste form or (2) development of disposal alternatives other than shallow-land burial. Development of an acceptable waste form for disposal would be difficult—and may not be practicable - for unalloyed DU metal (Appendix C).

Defining a DU form that is acceptable for disposal requires resolution of a wide range of issues associated with definition of an acceptable disposal technology and a suitable facility. All of the forms of uranium considered in this report have been disposed of directly at NTS (Thomas 1990). For instance, $5000 \mathrm{MT}$ of $\mathrm{UF}_{4}$ and $25 \mathrm{MT}$ of $\mathrm{UO}_{3}$ from Fernald have been disposed of. Although this experience indicates that disposal of DU forms is possible at NTS, the massive amounts of converted $\mathrm{DUF}_{6}$ envisioned in the $\mathrm{UF}_{6}$ Management Program will require that many issues be reexamined. Major issues related to waste acceptance at potential shallow-land burial sites such as NTS must be handled through the approval process specified in the new DOE Order 435.1.

- Technical issues include potential conflicts with existing WAC with respect to uranium concentration; density; physicochemical form (reactivity, content of fine particulates, pyrophorics); and, for commercial facilities, ${ }^{235} \mathrm{U}$ content.

- Forms of DU that were judged less desirable for extended storage because of reactivity, solubility, or pyrophoric behavior are also considered less desirable for direct disposal. These include $\mathrm{UO}_{3}$ and finely divided $\mathrm{UO}_{2}$ and uranium metal. The NRC has previously (NRC 1992) expressed a preference for $\mathrm{U}_{3} \mathrm{O}_{8}$ and rejected $\mathrm{UF}_{4}$ as a disposal form in 10 CFR 61 facilities in humid environments because of solubility and reactivity concerns and because the Environmental Impact Statement (EIS) supporting 10 CFR 61 did not envision the large quantities of DU indicated by the Louisiana Energy Services for their proposed enrichment facility in that state.

- Conversion to forms beyond those needed for safe storage (e.g., synthetic forms of natural uranium minerals, etc.) might be considered if encapsulation, stabilization, and other forms of treatment are needed. However, these could prove inadequate for disposal of the oxides or uranium metal. Such measures do not appear to be essential, based on current information.

- If DU oxide can be produced with a consistent bulk density of $\leq 2.6 \mathrm{~g} / \mathrm{cm}^{3}$ and without pyrophoric properties, it appears that the NTS WAC could be met without the need for additional treatment. Such criteria currently appear to favor $\mathrm{U}_{3} \mathrm{O}_{8}$ as a disposal form because the stable ceramic forms of $\mathrm{UO}_{2}$ exhibit higher densities. These conclusions are based on the following assumptions:

- The ${ }^{99} \mathrm{Tc},{ }^{237} \mathrm{~Np}$, and plutonium contents in DU will not affect compliance with the radiological concentration limits in the NTS WAC. However, the presence of such materials may increase waste characterization and certification costs.

- The long-term buildup of radon will not become an issue in assessing the acceptance of DU at LLW disposal sites. 
- The acceptance of DU at DOE facilities such as NTS may be limited by the outcome of pending National Environmental Policy Act (NEPA) actions and litigation related to complex-wide waste management.

- Experience has shown that acceptance by potentially affected states (particularly over "equity" issues) and other stakeholders, such as the NRC, will also be a significant concern. Stakeholder concerns are likely to be exacerbated by recent publicity about the presence of plutonium derived from recycle of reactor fuels at the Oak Ridge and Paducah sites.

- Intensive technical discussions with waste acceptance staff at LLW disposal sites and interactions with major stakeholders are needed to determine whether both the technical and the sociopolitical issues can be resolved without having to resort to waste treatment or to other disposal alternatives.

The following actions must be completed before disposal at NTS can be accomplished:

- Initiate negotiations with the Waste Management Organization at DOE/Nevada to determine whether the DU should be targeted for Area 3 or Area 5 at NTS, evaluate the need to increase NTS disposal capacity to accommodate the large quantities of DU form to be disposed of, and review the waste streams (product forms) and their characteristics and determine the ability to meet the WAC directly or develop the necessary justification for exemptions.

- Initiate the process to achieve approved shipper status to NTS.

- Complete the existing NEPA documentation for the NTS and DOE Waste Management EIS and then initiate the additional NEPA documentation required for disposal of all DUF 6 conversion alternatives.

\section{DISCUSSION}

The optimum conversion form is dependent on the assumed endpoint. A single form that is optimal for interim storage and either beneficial reuse or disposal cannot currently be defined in exact terms.

- The process for selecting new beneficial uses with greatly increased revenues or cost offsets is incomplete; thus, an optimal form for reuse cannot yet be identified. Completion of such assessments continues to be a "critical path" activity. High costs for secondary conversions needed for beneficial reuse argue against making a commitment to a single conversion form until further information is available.

- Conversion forms that can be stored safely may not be disposable without secondary confinement, stabilization, or other treatment to produce an acceptable waste form. Although $\mathrm{UF}_{4}$ can be stored adequately in suitable containers, the disposal of massive quantities of untreated $\mathrm{UF}_{4}$ in the same containers cannot currently be ensured. Some of the physical and radiological characteristics of the forms considered optimum for storage are in conflict with the WAC for existing disposal sites.

- Oxides $\left(\mathrm{U}_{3} \mathrm{O}_{8}\right.$ or sintered $\left.\mathrm{UO}_{2}\right)$ and $\mathrm{UF}_{4}$ appear to be favored over uranium metal when current information is considered collectively on (1) technical feasibility, ES\&H and engineering considerations, and costs of conversion options; (2) chemical stability and ES\&H issues associated with storage; (3) costs vs potential benefits of reuse; and (4) waste disposal options and requirements.

- Because of concerns about the feasibility of plasma-based conversion, consideration of conversion costs alone strongly favors $\mathrm{UF}_{4}, \mathrm{U}_{3} \mathrm{O}_{8}$, or $\mathrm{UO}_{2}$ over uranium metal.

- Both $\mathrm{UF}_{4}$ and $\mathrm{U}_{3} \mathrm{O}_{8}$ are favored over $\mathrm{UO}_{2}$ on the basis of lower conversion costs (Appendix A; also see Elayat et al. 1997 for additional $\mathrm{U}_{3} \mathrm{O}_{8}-\mathrm{UO}_{2}$ cost comparisons). 
- Because its lower uranium concentration, lower potential bulk density, and lack of pyrophoric behavior appear to offer a higher potential for meeting acceptance criteria of waste disposal sites such as the NTS without stabilization or other treatment, $\mathrm{U}_{3} \mathrm{O}_{8}$ is favored over $\mathrm{UO}_{2}$ or uranium metal.

- The oxide $\mathrm{U}_{3} \mathrm{O}_{8}$ has advantages over $\mathrm{UF}_{4}$ because it (1) has a lower solubility and is the most thermodynamically stable form in the environment, (2) is supported by a major stakeholder (NRC) as a preferred disposal form, and (3) thus appears to have a significantly higher potential for disposal at existing sites without stabilization or other treatment. Uranium tetrafluoride may have acceptable solubility and stability (the environmental impact has not been analyzed) and does have a distinct advantage in terms of LCCs.

- Although disposal of $\mathrm{U}_{3} \mathrm{O}_{8}$ powder may require secondary confinement (e.g., lined drums), it currently appears that stabilization or other treatment of fine particulates (e.g., via grouting) is potentially avoidable.

- Because interim storage appears to be more costly than shallow-land disposal at a DOE site such as NTS, the potential for retrievable disposal (e.g., use of a dedicated burial trench at NTS as both a storage and a disposal site) should be explored.

- Because the scale of potential DOE disposals is unprecedented, nontechnical issues (e.g., stakeholder equity concerns) or technical issues concerns not currently thought to be significant (e.g., long-term radon buildup) could tip the scales in favor of waste treatment or alternative disposal technologies.

- Expert opinion is divided over which of the preceding factors are most relevant (and which issues associated with these factors are most significant) to selection of the optimal DUF ${ }_{6}$ conversion form. However, total LLC will probably be the determining factor as long as acceptable (although not optimal) storage and disposal forms can be produced.

\section{CONCLUSIONS}

Consideration of the various components of analysis discussed in the preceding sections indicates that LCC will probably be the dominant determinant as long as the product is acceptable. Therefore, the three most promising forms of uranium to which the depleted $\mathrm{UF}_{6}$ could be converted are thought to be the following (in order of preference):

- The most promising form for conversion is $\mathrm{UF}_{4}$ (with highest expected flexibility for reuse, potentially the lowest costs, and moderate storage and disposal concerns), based on the following factors: (1) moderate stability and compatibility with long-term storage; (2) lowest estimated LCCs (for primary conversion and for the aggregate of conversion, storage, and disposal), assuming that this form can be disposed of without stabilization or treatment (potentially a significant issue); and (3) highest level of flexibility in reuse because the form is an intermediate that can be used for conversion to either $\mathrm{UO}_{2}$ or uranium metal.

- Second to $\mathrm{UF}_{4}$ is $\mathrm{U}_{3} \mathrm{O}_{8}$ (a potential compromise because of minimal storage and disposal concerns, intermediate costs, and reasonable flexibility in reuse), based on the following factors: (1) high stability and compatibility with long-term storage (even though containerization would be required); (2) highest potential for disposal (including retrievable disposal) without further treatment; (3) highest level of expected stakeholder acceptance as a disposal form; (4) relatively low estimated LCCs (conversion, storage, and disposal); and (5) moderate compatibility with reuse [although requiring single-step conversion to $\mathrm{UO}_{2}$, the form desired for uses identified in the roadmapping activity as being of highest priority for consideration (A group)]. 
- Sintered forms of $\mathrm{UO}_{2}$ rank third (as the best current fit to the form expected for high-priority beneficial reuses, coupled with minimal storage and low disposal concerns, but slightly higher overall costs), based on the following factors: (1) highest stability and compatibility with long-term storage (requiring less rigor in containerization than $\mathrm{U}_{3} \mathrm{O}_{8}$ ); (2) moderate to high potential for disposal without further treatment (e.g., assuming that a bulk density of $\leq 4 \mathrm{~g} / \mathrm{cm}^{3}$ and/or variances to NTS WAC can be achieved); (3) high expected level of stakeholder acceptance as a disposal form; (4) slightly higher (than the other two options) estimated LCCs (slightly higher than $\mathrm{U}_{3} \mathrm{O}_{8}$ for conversion (due to sintering operations) but with potentially higher costs for disposal); and (5) highest compatibility with high-priority reuse options (although manipulation of the physical form would be required to reuse material in powder form).

There appears to be a higher level of uncertainty associated with the conclusions about $\mathrm{UF}_{4}$ from the LCC analysis, due in part to (1) limited analysis of environmental impacts of UF $_{4}$ in the PEIS; (2) a higher expected level of stakeholder concerns related to (limited) reactivity and solubility, leading to a lower potential for disposal without treatment (via grouting or secondary conversion to an oxide) than either $\mathrm{U}_{3} \mathrm{O}_{8}$ or $\mathrm{UO}_{2}$; (3) limitations in current information on primary and secondary conversion costs; and (4) potentially higher residual costs for secondary conversion, needed for beneficial reuse as either $\mathrm{UO}_{2}$ or uranium metal, than for either $\mathrm{U}_{3} \mathrm{O}_{8}$ or $\mathrm{UO}_{2}$ (data for option 7 in Table 1; also see Appendix A).

\section{REFERENCES}

DOE 1995. Depleted Uranium: A DOE Management Challenge, DOE/EM-062, U.S. Department of Energy, Washington, D.C., October 1995.

DOE 1999. Programmatic Environmental Impact Statement for Alternative Strategies for the Long-Term Management and Use of Depleted Uranium Hexafluoride, DOE/EIS-029, U.S. Department of Energy, Washington, D.C., April 1999.

Elayat, H., Zoller, J., and Szytel, L. 1997. Cost Analysis Report for the Long-Term Management of Depleted Uranium Hexafluoride, UCRL-AR-127650, Lawrence Livermore National Laboratory, Livermore, Calif., May 1997.

Folga, S., Kier, P., and Thimmapuram, P. 1999a. Cost Estimate Report for the Long-Term Management of Depleted Uranium Hexafluoride: Storage of Depleted Uranium Metal, Argonne National Laboratory, Argonne, Ill., Sept. 1, 1999.

Folga, S., Kier, P., and Thimmapuram, P. 1999b. Engineering Analysis Report for the Long-Term Management of Depleted Uranium Hexafluoride: Storage of Depleted Uranium Metal, Argonne National Laboratory, Argonne, Ill., Sept. 1, 1999.

Forsberg, C.W. 1997. "Depleted Uranium Oxides and Silicate Fill Materials as Spent Nuclear Fuel Waste Package Fill Materials,” Mater. Res. Soc. Symp. Proc. 465, 615-622.

Thomas, D. 1999. Personal communication from the former manager responsible for waste management at Fernald to J. R. Hightower, October 1999. 
NRC 1992. Letter from J. W. N. Hickey, Chief Fuel Cycle Safety Branch, U.S. Nuclear Regulatory Commission to Louisiana Energy Services, L.P., Docket No. 70-3070, U.S. Nuclear Regulatory Commission, Washington, D.C., Sept. 22, 1992. 
Appendix A

SIMPLIFIED LIFE CYCLE COSTS FOR SELECTED DUF CONVERSION AND MANAGEMENT OPTIONS 


\title{
APPENDIX A. SIMPLIFIED LIFE CYCLE COSTS FOR SELECTED DUF 6 CONVERSION AND MANAGEMENT OPTIONS
}

\author{
R. Lowell Reid \\ Engineering Technology Division \\ Oak Ridge National Laboratory
}

\section{INTRODUCTION}

The final DOE Programmatic Environmental Impact Statement (PEIS) regarding the "Long-Term Management and Use of Depleted Uranium Hexafluoride"(Ref.1) considered alternatives for storage and disposal of uranium oxide, covered the uranium metal alternative for "beneficial use" options only, and did not consider options involving conversion to $\mathrm{UF}_{4}$. This present study compares storage, disposal, and use options for uranium metal, as well as uranium oxide and $\mathrm{UF}_{4}$. The conventional technology for conversion of $\mathrm{UF}_{6}$ to metal involves reduction of $\mathrm{UF}_{6}$ to $\mathrm{UF}_{4}$ with hydrogen and subsequent reduction of $\mathrm{UF}_{4}$ to metal using magnesium metal. This conventional metallothermic reduction technology is expensive and produces relatively high volumes of waste. To investigate the incentive for consideration of advanced technologies, we also considered a hypothetical new process (perhaps based on plasma processing) that would produce metal as a product with operating costs similar to those for producing $\mathrm{U}_{3} \mathrm{O}_{8}$. This hypothetical process would avoid addition of reactants (magnesium) and the associated $\mathrm{MgF}_{2}$ waste products and also produces $\mathrm{F}_{2}$ gas to maximize by-product credit.

This study determines simplified life cycle costs (LCCs) for the following seven options:

1. Conversion to $\mathrm{U}_{3} \mathrm{O}_{8}$ and disposal in shallow-land burial trenches at the Nevada Test Site (NTS).

2. Conversion to metal; disposal as in Scenario 1.

3. Conversion to $\mathrm{UF}_{4}$; disposal as in Scenario 1.

4. Conversion to $\mathrm{U}_{3} \mathrm{O}_{8}$, secondary conversion to $\mathrm{UO}_{2}$ and metal, and beneficial reuse in the form of either storage casks $\left(\mathrm{UO}_{2}\right)$ or multipurpose shields (metal) for spent nuclear fuel.

5. Conversion to metal, secondary conversion of half of the metal to $\mathrm{UO}_{2}$, and beneficial reuse as in Scenario 4.

6. Conversion to $\mathrm{UF}_{4}$, secondary conversion to $\mathrm{UO}_{2}$ and metal, and beneficial reuse as in Scenario 4.

7. Conversion to a mix of $\mathrm{U}_{3} \mathrm{O}_{8}$ and metal, secondary conversion of the $\mathrm{U}_{3} \mathrm{O}_{8}$ to $\mathrm{UO}_{2}$, and beneficial reuse as in Scenario 4.

The base LCC analysis for those options considering the conversion of the DUF $_{6}$ to a metal end-product (Options 2, 4, 5, and 7) assumed the use of commercial batch two-step reduction process utilizing chipped magnesium. In addition, the LCCs for the options employing uranium metal end products were also estimated by assuming that a hypothetical single-step process could be developed and implemented to convert $\mathrm{DUF}_{6}$ to uranium metal (Options $2 \mathrm{p}, 4 \mathrm{p}, 5 \mathrm{p}$, and $7 \mathrm{p}$ ). However, the development costs were not considered in this exercise. 


\section{SUMMARY}

A spreadsheet model was formulated to estimate simplified LCCs for conversion and disposition of approximately 450,000 $\mathrm{Mt}_{\text {of }} \mathrm{DUF}_{6}$ for candidate options comparing the costs of converting $\mathrm{DUF}_{6}$ to an oxide vs. converting it to a metal or to $\mathrm{UF}_{4}$. The major components of costs that were considered were those for conversion; storage; containers for storage and transport; transportation; beneficial use; and disposal. A detailed discussion of the cost model and assumptions are included in the next section of this report. Basically, the model assumes that costs scale with throughput for each of the reactant, product, and waste streams considered. Conversion cost for DUF 6 to an oxide is based on a recent Bechtel conceptual design (Ref. 2). The LCCs for conversion of DUF 6 to uranium metal for the commercial batch two-step reduction process are scaled from the preconceptual design and cost estimate in the Cost Analysis Report (Ref. 3), a companion report to the PEIS. The cost for converting DUF 6 to $\mathrm{UF}_{4} \mathrm{was}$ estimated from the reference costs and process flow diagram for the continuous conversion of $\mathrm{DUF}_{6}$ to uranium metal provided in Refs. 3 and 4, respectively. Secondary conversion from metal and $\mathrm{U}_{3} \mathrm{O}_{8}$ forms to an oxide form $\left(\mathrm{UO}_{2}\right)$ preferred for beneficial use is based on BNFL recommendations; secondary conversion from $\mathrm{U}_{3} \mathrm{O}_{8}$ to uranium metal is assumed to be equivalent to conversion of DUF $\mathrm{F}_{6}$ to uranium metal. Costs for secondary conversion of $\mathrm{UF}_{4}$ to $\mathrm{UO}_{2}$ or metal are estimated from information in Ref. 3. The beneficial use costs [capital and operating costs required for converting the $\mathrm{UO}_{2}$ or metal products to casks or shields for spent nuclear fuel (SNF)] are also scaled from values in Ref. 3. The cost of storing the oxide, $\mathrm{UF}_{4}$, or metal product of primary conversion for seven years is estimated as a function of required storage volume based on a Bechtel design for a $\mathrm{U}_{3} \mathrm{O}_{8}$ storage facility. Container costs for product and waste are based primarily on use of 55-gal drums. Transportation costs are based on the use of flatbed trucks for the transport of products and wastes to the Nevada Test Site (NTS) from Paducah, Kentucky. Disposal costs are estimated using a unit disposal cost of $\$ 7.50$ per $\mathrm{ft}^{3}$ at the NTS.

The minimum simplified LCC for the seven base options for conversion and disposition of approximately 450,000 Mt of $\mathrm{DUF}_{6}$ was for Option 3, \$514 M (conversion to $\mathrm{UF}_{4}$, storage for seven years, followed by disposal), followed by Option 1, \$915 M (conversion to an oxide, storage for seven years, followed by disposal). If "goal value" estimates for conversion costs are invoked for the hypothetical conversion process, then Option $2 p$ (conversion to uranium metal, stored for seven years, followed by disposal) achieves a LCC, $\$ 763 \mathrm{M}$, that is intermediate between that of Options 1 and 3. The LCCs for each of the options considered are presented in the "Results" section of this report.

The options employing "beneficial use" of the $\mathrm{DUF}_{6}$ result in high life cycle costs based on LCCs for the options and associated assumptions used in this study because potential cost savings from alternate approaches were not considered. For the base set of options, i.e., Options 1-7, the minimum LCC for "beneficial use" is Option 7 (conversion of $\mathrm{DUF}_{6}$ to a mix of metal and oxide, stored for seven years, followed by beneficial reuse of the products) with a LCC of $\$ 2214 \mathrm{M}$. This value is $\$ 1700 \mathrm{M}$ greater than the "minimum-cost" Option 3. If use of the hypothetical conversion process for metal is assumed (along with the associated "goal" conversion costs), then the minimum-cost "beneficial use" option is Option $5 \mathrm{p}$ (conversion of $\mathrm{DUF}_{6}$ to metal using a new process, storage for seven years, followed by beneficial reuse as a mix of oxide and metal) with a LCC of $\$ 1610 \mathrm{M}$. This value is some $\$ 1096 \mathrm{M}$ greater than for the previously indicated "minimum-cost" Option 3 and $\$ 847 \mathrm{M}$ greater than for Option $2 p$, which also utilizes a conversion process. For the "beneficial use" options to be economically viable, the costs avoided (if any) by the users of products containing the DUF $_{6}$ would have to compensate for the "excess" cost incurred by selecting the "beneficial use" alternative for disposition of the DUF . 


\section{MODEL \& ASSUMPTIONS}

A spreadsheet was prepared to determine LCCs for each of the five $\mathrm{DUF}_{6}$ conversion and disposition options considered in this study. The final state of the $\mathrm{DUF}_{6}$, after a seven-year post conversion storage period is either disposal or beneficial use. Some components of LCCs were omitted in this study; typically only those costs which vary among the options were accounted for. Examples of costs not

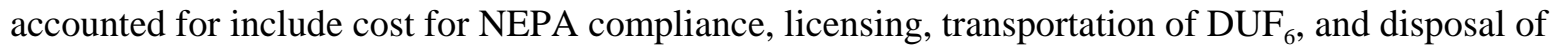
empty DUF ${ }_{6}$ cylinders. The major LCC components considered for each option included those for conversion; storage; containers for storage and transport; transportation; and disposal. The models, including assumptions used, for each of the major LCC components are described below.

\section{Conversion Models}

\section{Conversion to oxide:}

Capital costs for converting $\mathrm{DUF}_{6}$ to an oxide, $\mathrm{U}_{3} \mathrm{O}_{8}$, are linearly scaled for this study as a function of throughputs based on a conceptual design performed by Bechtel (Ref. 2). Engineering costs were estimated at $14.4 \%$ of the process equipment, process facilities, and balance of plant cost. The process flow diagram in this Bechtel report is consistent with converting 450,000 metric tons of $\mathrm{DUF}_{6}$ stored at the Paducah Gaseous Diffusion Plant into $\mathrm{U}_{3} \mathrm{O}_{8}$ and anhydrous HF. Values on the Bechtel flow diagram were modified slightly in the recent comparative study of one-site vs. two-site scenarios for DUF 6 conversion (Ref. 4). The modified values, which are contained in Fig. 3.3c of Ref. 4, were used to estimate the flows of materials in the $\mathrm{DUF}_{6}$ conversion process streams for this study, specifically, for DUF $_{6}, \mathrm{U}_{3} \mathrm{O}_{8}, \mathrm{AHF}, \mathrm{CaF}_{2}$, and grout.

O\&M staffing costs, materials costs, and costs for utilities were also scaled from Ref. 2 as a linear function of throughput. However, the costs for containers in the Bechtel materials cost category (consumables) were removed since costs of containers are computed and tabulated separately as a specific category in this study. Initial facility start-up costs were estimated to be sixty five percent of labor cost for one years' operation of the conversion facility.

Decontamination and decommissioning (D\&D) costs were estimated as $10 \%$ of the capital costs for this study, consistent with the methodology of Ref. 2.

\section{Conversion to metal: (Batch metallothermic)}

Batch metallothermic reduction of DUF $_{6}$ to uranium metal was considered in the PEIS. A breakdown of costs for this conversion option is presented in Ref. 3 . However, these costs are presented in discounted dollars. Reference 3 also provides a similar breakdown of costs, also in discounted dollars, for a process for conversion to a $\mathrm{U}_{3} \mathrm{O}_{8}$ end product. The assumption was made that the major elements of the discounted costs for these two conversion options, such as for process equipment, process facilities, balance of plant, O\&M costs, etc., could be used in combination with the corresponding constant dollar cost estimates for conversion to $\mathrm{U}_{3} \mathrm{O}_{8}$ to estimate an equivalent constant dollar cost for the metal conversion process. This was done by multiplying the ratios of discounted costs for each of the major 
cost elements of the metal and oxide conversion options from the Cost Analysis Report (Ref. 3) by the corresponding costs for $\mathrm{U}_{3} \mathrm{O}_{8}$ conversion obtained from the breakdown supplied by Bechtel in Ref. 2, i.e.,

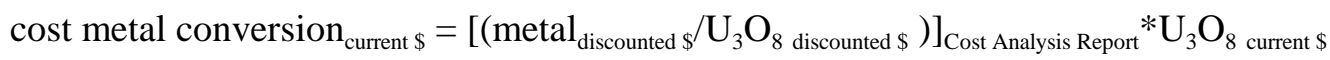

and then summing the results to obtain total costs. An implied assumption is that the spread of the dollars over time in the conversion options (metal and oxide) in the Cost Analysis Report and in the Bechtel designs is about the same, i.e., equivalent spending profiles. An input/output diagram for the batch reduction of $\mathrm{DUF}_{6}$ to metal taken from Ref. 5 was used to determine the flow rates of the various product streams for use in cost scaling.

\section{Conversion to metal: (hypothetical new process)}

No conceptual designs and cost estimates were available for a proposed evolving conversion process. However, a "goal" value for conversion costs will be assumed to be the same as the conversion to an oxide, assuming current development is successful. This common estimate for conversion cost was $\$ 4 / \mathrm{kg} \mathrm{U}$.

Thus, the costs for conversion from $\mathrm{DUF}_{6}$ to metal using the new process for this simplified study were set equal to, and scaled from, the costs for conversion of $\mathrm{DUF}_{6}$ to $\mathrm{U}_{3} \mathrm{O}_{8}$ provided by Bechtel in Ref. 2. The AHF product stream from the conventional process for conversion to $\mathrm{U}_{3} \mathrm{O}_{8}$ was also used as a surrogate for the $\mathrm{F}_{2}$ product stream from the plasma-based conversion process. For the elements of the conversion costs included in this study (including the revenue from the sale of $\mathrm{AHF}$ or $\mathrm{F}_{2}$ ), the net conversion cost was $\$ 1.9 / \mathrm{kg} \mathrm{U}$.

Since no flow diagram was available for the new process for conversion of $\mathrm{DUF}_{6}$ to metal, product and waste streams flows were based on the previously cited input/output diagram for the conventional twostep batch reduction of DUF 6 to metal taken from Ref. 5. For the plasma-based process, the $\mathrm{CaF}_{2}$ and $\mathrm{MgF}_{2}$ streams were eliminated. However, the grout waste stream was maintained as a surrogate for waste streams that are currently undefined for the plasma-based process.

\section{Conversion to $\mathrm{UF}_{4}$}

It was also necessary to make simplifying assumptions for the LCC analysis for Options 3 and 6 involving conversion to $\mathrm{UF}_{4}$ because process flow diagrams and accompanying reference cost values were not readily available. The cost for converting $\mathrm{DUF}_{6}$ to $\mathrm{UF}_{4}$ was estimated from the reference costs and process flow diagram for the continuous conversion of DUF $F_{6}$ to uranium metal provided in Refs. 3

and 5, respectively. The first step in the flow diagram shown in Ref. 5 involves conversion of DUF 6 to $\mathrm{UF}_{4}$. Based on the estimated costs of various elements of the flow diagram shown in Ref. 5, it was assumed that $25 \%$ of the total discounted cost given in Ref. 3 for conversion of DUF 6 to uranium metal was associated with the initial conversion step leading to $\mathrm{UF}_{4}$ (including processing of the AHF produced). The cost estimate for conversion to $\mathrm{UF}_{4}$ used in the current study was then derived by converting the discounted cost to a constant dollar cost as described above.

The costs associated with the waste streams (primarily grouted neutralization solids and $\mathrm{MgF}_{2}$ produced downstream of the $\mathrm{DUF}_{6}$ to $\mathrm{UF}_{4}$ conversion step) are included in the costs for secondary conversion of $\mathrm{UF}_{4}$ to metal and for secondary conversion of $\mathrm{UF}_{4}$ to $\mathrm{UO}_{2}$ for the beneficial use option. 


\section{$\underline{\text { Secondary Conversion Costs }}$}

Scenarios for Options 4 and 5 of this study require secondary conversion of the $\mathrm{U}_{3} \mathrm{O}_{8}$ and uranium metal following the initial conversion from $\mathrm{DUF}_{6}$, i.e., from the storage forms to the use forms. The cost for the secondary conversion of $\mathrm{U}_{3} \mathrm{O}_{8}$ to uranium metal was arbitrarily set to be equal to the cost for primary conversion of $\mathrm{DUF}_{6}$ to uranium metal.

The cost of the secondary conversion of one-half of the $\mathrm{UF}_{4}$ to uranium metal for beneficial use (Option 6) was obtained by taking the product of 0.5 times the net cost for converting DUF 6 to uranium metal via the batch metallothermic process (from Option 2) less the cost for primary conversion of $\mathrm{DUF}_{6}$ to $\mathrm{UF}_{4}$ (obtained as described above).

The cost of the secondary conversion for one-half of the $\mathrm{UF}_{4}$ to $\mathrm{UO}_{2}$ for beneficial use (Option 6) was obtained by taking one-half of the cost for converting of $\mathrm{DUF}_{6}$ to $\mathrm{UO}_{2}$ from Ref. 3 (i.e., the $\mathrm{DUF}_{6}$ to $\mathrm{UO}_{2}$ conversion cost was used as a partial surrogate for the $\mathrm{UF}_{4}$ to $\mathrm{UO}_{2}$ conversion cost) and then converting this cost to a constant dollar estimate using the methodology previously described. Table 1 shows the constant dollar cost for conversion of $\mathrm{DUF}_{6}$ to $\mathrm{UO}_{2}$.

\section{"Beneficial Use" Capital \& Operating Costs Model}

Conceptual designs and estimated costs for beneficial use of $\mathrm{UO}_{2}$ or uranium metal were also provided in Ref. 3. However, the costs for constructing and operating facilities to produce casks for storage of SNF from the oxide or to make shields for transporting SNF from the metal were also presented in discounted dollars. Therefore, similar assumptions and procedures were used as previously described to convert these discounted cost into constant dollars. The assumption was made that ratios of major elements of discounted cost, such as process equipment, process facilities, balance of plant, O\&M costs, etc., from the metal "beneficial use" option and the $\mathrm{U}_{3} \mathrm{O}_{8}$ conversion option from the Cost Analysis Report (both of the same vintage) could be multiplied by the recently estimated constant dollar cost breakdown for the $\mathrm{U}_{3} \mathrm{O}_{8}$ conversion supplied by Bechtel (Ref. 2) to arrive at an equivalent constant dollar cost for the metal "beneficial use" option. The same approach was also taken to estimate the constant dollar costs for the oxide "beneficial use" option. Again, an implied assumption is that there are equivalent spending profiles over time in both the $\mathrm{U}_{3} \mathrm{O}_{8}$ conversion process and the beneficial use processes.

\section{Revenue Model}

The revenue derived from the sale of anhydrous HF (AHF) is estimated based on a price of $\$ 1.51 / \mathrm{kg}$, the same as used in Ref. 5.

The constant dollar revenue from the beneficial use options, e.g., radiation shielding applications, was taken to be $\$ 200,000$ per shield application (Ref. 3). The oxide is assumed to be used to make DUCRETE for the manufacture of casks for dry storage of SNF. The metal would be used in casting multipurpose shields for storage, transportation, and disposal of SNF. The number of shields produced was scaled in the LCC spreadsheet based on 28,000 MT DUF 6 producing 480 DUCRETE casks or 453 uranium metal shields (Ref. 3). 


\section{Storage Model}

Costs for storing the metal, oxide, and fluoride forms of uranium for seven years in this simplified LCC study were scaled based on the volume of the material to be stored, which is a function of the material throughput (pounds) and the density of the material (pounds $/ \mathrm{ft}^{3}$ ). The impact of the higher density of the uranium metal (density of about $19 \mathrm{~g} / \mathrm{cm}^{3}$ ) compared to the oxide or fluoride forms $\mathrm{U}_{3} \mathrm{O}_{8}$ (estimated densities of $2.6-3.0 \mathrm{~g} / \mathrm{cm}^{3}$ ) on facility structural design and associated cost variation cannot be determined without performing a conceptual design for a uranium metal storage facility. However, a conceptual design and preliminary cost estimate for storage of $\mathrm{U}_{3} \mathrm{O}_{8}$ has been prepared by Bechtel (Ref. 6). Their cost estimate ( $\$ 20 \mathrm{M}$ for storing one year's output of a conversion facility 14,415 metric tons; see their Table 2) is assumed to be scalable to obtain a cost for a storage facility for uranium metal (or $\mathrm{UF}_{4}$ ) by using the ratio of the volumes of $\mathrm{U}$ metal ( $\mathrm{or} \mathrm{UF}_{4}$ ) and $\mathrm{U}_{3} \mathrm{O}_{8}$ produced per year (which are a function of density and facility throughput) raised to the 0.5 power, i.e.,

$$
\text { storage cost metal/ } \mathrm{UF}_{4}=\text { storage cost } \mathrm{U}_{3} \mathrm{O}_{8} *\left[\text { volume metal/ } \mathrm{UF}_{4} / \text { volume } \mathrm{U}_{3} \mathrm{O}_{8}\right]^{0.5}
$$

This type of cost algorithm has been used for comparing costs for facilities for nuclear and coal-fired power plants as a function of the variation in generating capacity in megawatts and is assumed to apply to the scaling of storage facility costs based on the variation in the volume to be stored.

\section{Container Model}

The number of required storage containers (drums) for the product streams was scaled as a function of stream throughput. The number of drums and the associated throughputs for $\mathrm{AHF}, \mathrm{CaF} 2$, and grout were taken from Fig. 3.3c in Ref. 4 (as noted earlier). The containers for $\mathrm{U}_{3} \mathrm{O}_{8}$ were assumed to be 55-gal carbon steel drums (as in Ref. 2), each of which would contain 1200 pounds of $\mathrm{U}_{3} \mathrm{O}_{8}$ (at a density of approximately $2.6 \mathrm{~g} / \mathrm{cm}^{3}$ ). These drums were estimated to cost $\$ 86.60$ each.

The assumptions for the containers for the uranium metal and the $\mathrm{MgF}_{2}$ products were taken from Ref. 7 . The containers for uranium metal are "strong tight" metal boxes, having a volume of $11 \mathrm{ft}^{3}$, and containing 8500 pounds of uranium. The estimated cost per box is $\$ 500$. The $\mathrm{MgF}_{2}$ is assumed to be stored in 55 -gal drums, packaged to $75 \%$ of theoretical density $\left(147 \mathrm{lb} / \mathrm{ft}^{3}\right)$. Each drum would thus hold $1080 \mathrm{lb}$ of $\mathrm{MgF}_{2}$.

The containers for $\mathrm{UF}_{4}$ were assumed to be 55-gal drums of the same type used for $\mathrm{U}_{3} \mathrm{O}_{8}$, each of which would contain 1200 pounds of $\mathrm{UF}_{4}$ (at a density of approximately $3 \mathrm{~g} / \mathrm{cm}^{3}$ ).

\section{Transportation Model}

The transportation costs for the AHF (assumed to be shipped from Paducah to Metropolis), $\mathrm{CaF}_{2}$, and grout (each assumed to be shipped from Paducah to the NTS for disposal) were scaled as a function of throughput from the values given in Ref. 4. The transportation costs for the $\mathrm{U}_{3} \mathrm{O}_{8}$, uranium metal, $\mathrm{UF}_{4}$, and $\mathrm{MgF}_{2}$ (each also assumed to be shipped from Paducah to the NTS) were estimated based on flatbed 
truck shipments, at a weight limit per truckload of 44,000 pounds. The shipping cost was estimated to be $\$ 1.50 / \mathrm{mi}$.

\section{Disposal Model}

The disposal costs were based on a unit disposal cost of $\$ 7.50 / \mathrm{ft}^{3}$ at the NTS. Most of the material is assumed to be disposed of in 55-gal drums, except for the uranium metal which is assumed to be in small metal boxes (11 $\mathrm{ft}^{3}$ each).

\section{RESULTS}

These results are based on conversion and disposition of approximately 450,000 metric tons (MT) of DUF $_{6}$ over a 25 -year period. This throughput was used by Bechtel in the conceptual design for a DUF 6 to $\mathrm{U}_{3} \mathrm{O}_{8}$ conversion plant to be located in Paducah, Kentucky (Ref. 2). Results are based on the models and assumptions previously described.

Tables 2,3, and 5 show the simplified LCCs for the "disposal" options involving conversion to oxide and metal, Options 1, 2, and 3, respectively. Option 1 specifies conversion of DUF $\mathrm{D}_{6}$ to an oxide $\left(\mathrm{U}_{3} \mathrm{O}_{8}\right)$, storage of the oxide for seven years, followed by disposal. Option 2 is similar, except the $\mathrm{DUF}_{6}$ is first converted to uranium metal, stored for seven years, and then disposed of. As stated in the "Model and Assumptions" section of this report, the uranium metal conversion is assumed to be achieved by the commercial, state-of-the-art batch metallothermic reduction process, which requires the addition of magnesium as a reactant. Comparing Tables 2 and 3, it is observed that this DUF $_{6}$ to uranium metal process is much more costly than the $\mathrm{DUF}_{6}$ to $\mathrm{U}_{3} \mathrm{O}_{8}$ process, by about a factor of 2.6 , or $\$ 587 \mathrm{M}$ for the oxide conversion compared to $\$ 1537 \mathrm{M}$ for the metal conversion. The metal option has a lower storage facility cost (due to the lower volume of uranium metal to be stored), but higher total container and transportation costs, primarily associated with the $\mathrm{MgF}_{2}$ waste component that is produced only in conversion to metal. The total disposal costs at NTS are somewhat lower for the metal option due to the lower volume of uranium compared to the oxide, but again the cost for disposition of the $\mathrm{MgF}_{2} \mathrm{waste}$ degrades this advantage. The LCC for the metal option is about a factor of two greater than for the oxide option, or $\$ 1781 \mathrm{M}$ for the metal compared to $\$ 915 \mathrm{M}$ for the oxide.

Table 6 shows the simplified LCC for Option 4, which specifies conversion of DUF to $\mathrm{U}_{3} \mathrm{O}_{8}$, storage for seven years, followed by beneficial reuse as a mix of oxide and metal. The scenario shown in Table 6 is based on the assumption that one-half of the $\mathrm{U}_{3} \mathrm{O}_{8}$ will be used as an oxide and one-half of the $\mathrm{U}_{3} \mathrm{O}_{8}$ will be converted to uranium metal for reuse. This option, therefore, requires secondary conversion of the $\mathrm{U}_{3} \mathrm{O}_{8}$ to $\mathrm{UO}_{2}$, as $\mathrm{UO}_{2}$ is the feed material of choice for the beneficial use plants (Refs. 1 and 3), along with secondary conversion of $\mathrm{U}_{3} \mathrm{O}_{8}$ to uranium metal. This option eliminates the need for transportation to and disposal of the $\mathrm{U}_{3} \mathrm{O}_{8}$ at the NTS. However, the costs for secondary conversion are quite high ( $\$ 151 \mathrm{M}$ for $\mathrm{U}_{3} \mathrm{O}_{8}$ to $\mathrm{UO}_{2} ; \$ 768 \mathrm{M}$ for conversion of $\mathrm{U}_{3} \mathrm{O}_{8}$ to uranium metal), as are the costs for the facility and operations to provide the beneficial use $\left(\$ 341 \mathrm{M}\right.$ for use as $\mathrm{UO}_{2} ; \$ 404 \mathrm{M}$ for use as uranium metal). The estimated simplified LCC for this option is $\$ 2490 \mathrm{M}$.

Table 8 shows the simplified LCC for Option 5, which specifies conversion of DUF 6 to uranium metal, storage for seven years, followed by beneficial reuse as a mix of oxide and metal. The scenario shown in 
Table 8 is based on the assumption that one-half of the uranium metal will be converted to an oxide for reuse and one-half will be used as the metal. This option requires secondary conversion of one-half of the metal to $\mathrm{UO}_{2}$. This option also eliminates the need for transportation to and disposal of the $\mathrm{U}_{3} \mathrm{O}_{8}$ at the NTS. However, the cost of secondary conversion of the uranium metal to $\mathrm{UO}_{2}$ is $\$ 151 \mathrm{M}$, and the cost of the facility and operations to provide the beneficial use is $\$ 341 \mathrm{M}$ for use as $\mathrm{UO}_{2}$ and $\$ 404 \mathrm{M}$ for use as metal. The estimated simplified LCC for this option is $\$ 2629 \mathrm{M}$.

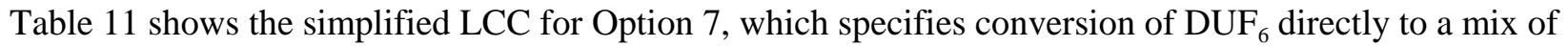
an oxide and a metal, storage for seven years as an oxide and a metal, followed by beneficial reuse of the products. This scenario avoids the secondary conversions required in Options 4 and 5 (other than the conversion of $\mathrm{U}_{3} \mathrm{O}_{8}$ to $\mathrm{UO}_{2}$ ). The scenario shown in Table 11 is for two one-half size plants, one producing oxide and the other producing metal. The estimated simplified LCC for this option is \$2214 $\mathrm{M}$, the lowest of the beneficial reuse options based on use of conventional conversion technologies.

\section{Effects of Hypothetical New Process for Conversion of DUF ${ }_{6}$ to Uranium Metal on LCCs}

Options 2, 4, 5, and 7 were reexamined assuming use of the hypothetical process for conversion of DUF 6 to metal, designated as Options 2p, 4p, 5p, and 7p, respectively. Options 1 and 3 are not affected by the selected metal conversion process; therefore, no Option $1 \mathrm{p}$ or $3 \mathrm{p}$ is necessary. As indicated in the "Model and Assumptions" section, the hypothetical new metal conversion process cost was set equal to, and scaled from, the oxide conversion process cost. Also, the hypothetical new process eliminates the required magnesium reactant stream and the $\mathrm{MgF}_{2}$ waste stream and associated costs. Using these assumptions and adjustments, the LCC of Option $2 \mathrm{p}$, shown in Table 4 , is $\$ 763 \mathrm{M}$, compared to $\$ 1781 \mathrm{M}$ for Option 2, which was based on use of the conventional $\mathrm{DUF}_{6}$ to metal conversion process. The LCC

of Option 2p (conversion to metal, storage, followed by disposal) is also $\$ 153 \mathrm{M}$ less than that for Option 1 (conversion to an oxide, storage, followed by disposal), reflecting the impact of the lower volume of the metal and of the elimination of the $\mathrm{MgF}_{2}$ waste stream on storage, containers, transportation, and disposal costs.

Results for Option $4 p$ (conversion of $\mathrm{DUF}_{6}$ to oxide, storage for seven years, followed by beneficial reuse as a mix of oxide and metal) are shown in Table 7. The LCC of Option 4p is \$2015 M, relative to \$2490 $\mathrm{M}$ for Option 4, reflecting the assumed lower cost for a new process for conversion of $\mathrm{U}_{3} \mathrm{O}_{8}$ to uranium metal (assumed to be equivalent to the cost for the new process for conversion of $\mathrm{DUF}_{6}$ to uranium metal) for this set of options and cost reductions associated with elimination of the $\mathrm{MgF}_{2}$ waste stream.

Results for Option $5 \mathrm{p}$ (conversion of $\mathrm{DUF}_{6}$ to uranium metal, storage for seven years, followed by beneficial reuse as a mix of oxide and metal) are shown in Table 9. The LCC of Option 5p is $\$ 1610 \mathrm{M}$, relative to $\$ 2629 \mathrm{M}$ for Option 5, reflecting the lower cost for the new process for conversion of $\mathrm{DUF}_{6}$ to metal and cost reductions associated with elimination of the $\mathrm{MgF}_{2}$ waste stream. Option $5 \mathrm{p}$ has the lowest LCC of the beneficial reuse options that involve use of the plasma-based DUF 6 to metal conversion process.

Results for Option $7 \mathrm{p}$ (conversion of $\mathrm{DUF}_{6}$ directly to a mix of and oxide and a metal, storage for seven years as an oxide and as a metal, followed by beneficial reuse of the products) are shown in Table 12. The LCC of Option $7 \mathrm{p}$ is $\$ 1704 \mathrm{M}$, relative to $\$ 2214 \mathrm{M}$ for Option 7 , also reflecting the assumed lower 
cost for conversion of $\mathrm{DUF}_{6}$ to metal and cost reductions associated with elimination of the $\mathrm{MgF}_{2} \mathrm{waste}$ stream.

\section{Effect of $\mathrm{UF}_{4}$ Conversion Alternative on LCCs}

Option 3, shown in Table 5 (convert $\mathrm{DUF}_{6}$ to $\mathrm{UF}_{4}$, store for seven years, followed by disposal) has the lowest simplified LCC, \$514 M, of the options considered because it (and Option 6) had the lowest primary conversion cost $(\$ 207 \mathrm{M})-$-about $1 / 3$ of that for Options 1 and $2 \mathrm{p}$. The simplified LCC value for Option 3 is $\$ 401 \mathrm{M}$ less than that for Option 1 (convert to $\mathrm{U}_{3} \mathrm{O}_{8}$, store, and dispose of) and $\$ 249 \mathrm{M}$ lower than for Option $2 p$ (plasma-based conversion to metal, storage, followed by disposal). The low costs for Option 3 result from the elimination of more rigorous and costly pyrohydrolysis or metallothermic reduction steps from the initial conversion activity.

The simplified LCC for the beneficial-reuse Option 6 is estimated to be $\$ 2274 \mathrm{M}$ (Table 10). The simplified LCC for Option 6 is only $\$ 60 \mathrm{M}$ greater than the LCC for beneficial-reuse Option 7 (which is based two half-size plants producing $\mathrm{U}_{3} \mathrm{O}_{8}$ and uranium metal by conventional processes, followed by storage and beneficial use) and $\$ 570 \mathrm{M}$ higher than for Option $7 \mathrm{p}$ (in which $\mathrm{DUF}_{6}$ is assumed to be converted to metal via the hypothetical new process, followed by interim storage, and subsequent reuse). The LCC for beneficial reuse in Option 6 (Table 10) reflects residual costs for secondary conversion that are higher than for any other alternative considered. This situation occurs because more rigorous and costly steps needed to complete the conversion to an oxide or metal were deferred from the initial conversion activity to the beneficial reuse activity. However, the difference between overall LCCs between Option 6 and Option 7 is small indicating only a small penalty for selecting $U_{4}$ as an intermediate conversion product even if other final use products are selected.

\section{REFERENCES:}

1. Programmatic Environmental Impact Statement for Alternative Strategies for the Long-Term Management and Use of Depleted Uranium Hexafluoride, DOE/EIS-029, April 1999, U.S. Department of Energy, Washington, D.C.

2. Bechtel Technology and Consulting, Preconceptual Design of a DUF ${ }_{6}$ Conversion Plant (1A), draft letter report, May 1999.

3. Elayat, H., Zoller, J., and Szytel, L., Cost Analysis Report for the Long-Term Management of Depleted Uranium Hexafluoride, UCRL-AR-127650, May 1997, Lawrence Livermore National Laboratory, Livermore, CA.

4. Comparative Evaluation of One-Site vs. Two-Sites Scenarios for Depleted Uranium Hexafluoride Conversion, Draft-Predecisional; not for Public Dissemination, June 1999.

5. Dubrin, J. W., et al., The Engineering Analysis Report for the Long-Term Management of Depleted Uranium Hexafluoride, UCRL-AR-124080, Vol. 2, Rev. 2, May 1997, Lawrence Livermore National Laboratory, Livermore, CA. 
6. Bechtel Technology and Consulting, Preconceptual Design of a DUF 6 Conversion Plant (2B), draft letter report, June 1999.

7. Hertzler,T. J., Nishimoto, D. D., and Otis, M. D., Depleted Uranium Disposal Options Evaluation, EGG-MS-11297, May 1994, EG\&G Idaho, Inc., Idaho Falls, ID. 
Table 1

$\mathrm{DUF}_{6}$ to $\mathrm{UO}_{2}$ Conversion

DUF $_{6}$ inventory, MT

447,875

Operating period, yrs

Annual Processing, MT/yr, DUF

17,915

Throughput, AHF MT/yr

Unit Revenue, AHF, $\$ / \mathrm{kg}$

Throughput, $\mathrm{UO}_{2} \mathrm{MT} / \mathrm{yr}$

Throughput, $\mathrm{CaF}_{2} \mathrm{MT} / \mathrm{yr}$

Throughput, U Metal MT/yr

Throughput, $\mathrm{MgF}_{2} \mathrm{MT} / \mathrm{yr}$

5,940

1.51

13,741

266

Throughput, Grout MT/yr

Conversion Costs

Category

$\$ M$, FY 2000

Engineering \& Design

Process Equipment

Process Facilities

36.6

34.5

Facility start-up

Subtotal, Up-Front Costs

49.7

13.2

O\&M Staffing

303.9

Materials, excluding containers $\quad 109.8$

Utilities

Revenue (AHF)

50.6

D\&D

$-224.6$

Subtotal, Other Conversion LCC

29.

470.6

TOTAL Conversion, LCC

$(\$ / \mathrm{kgU})$

774.5

2.6 
Table 2

\begin{tabular}{|c|c|}
\hline $\begin{array}{l}\text { Life Cycle Costs for Option } 1 \\
\text { (convert to } \mathrm{U}_{3} \mathrm{O}_{8} \text {, store, dispose }\end{array}$ & \\
\hline DUF $_{6}$ inventory, MT & 447,875 \\
\hline Operating period, yrs & 25 \\
\hline Annual Processing, MT/yr, DUF6 & 17,915 \\
\hline Throughput, AHF MT/yr & 5,940 \\
\hline Unit Revenue, AHF, $\$ / \mathrm{kg}$ & 1.51 \\
\hline Throughput, $\mathrm{U}_{3} \mathrm{O}_{8} \mathrm{MT} / \mathrm{yr}$ & 14,415 \\
\hline Throughput, $\mathrm{CaF}_{2} \mathrm{MT} / \mathrm{yr}$ & 266 \\
\hline Throughput, U Metal MT/yr & 0 \\
\hline Throughput, $\mathrm{MgF}_{2} \mathrm{MT} / \mathrm{yr}$ & 0 \\
\hline Throughput, Grout MT/yr & 740 \\
\hline $\begin{array}{cc}\text { Conversion Costs } \\
\end{array}$ & \\
\hline Category & $\$ M, F Y 2000$ \\
\hline Engineering \& Design & 25.4 \\
\hline Process Equipment & 42.9 \\
\hline Process Facilities & 91.6 \\
\hline Balance of Plant & 42.1 \\
\hline Facility start-up & 11.6 \\
\hline Subtotal, Up-Front Costs & 213.7 \\
\hline O\&M Staffing & 446.0 \\
\hline Materials, excluding containers & 87.5 \\
\hline Utilities & 44.6 \\
\hline Revenue (AHF) & -224.6 \\
\hline D\&D & 20.2 \\
\hline Subtotal, Other Conversion LCC & 373.7 \\
\hline TOTAL Conversion, LCC & 587.4 \\
\hline$(\$ / \mathrm{kgU})$ & 1.9 \\
\hline Product Storage Facility Costs & \\
\hline $\begin{array}{l}\mathrm{U}_{3} \mathrm{O}_{8}--7 \text { years' capacity } \\
\text { Uranium Metal--7 years' capacity }\end{array}$ & $\begin{array}{r}140.0 \\
0.0\end{array}$ \\
\hline Total Facility Storage Costs & 140.0 \\
\hline \begin{tabular}{|c|} 
Container Costs \\
\end{tabular} & \\
\hline $\mathrm{U}_{3} \mathrm{O}_{8}$ drums & 57.2 \\
\hline $\mathrm{CaF}_{2}$ drums & 1.0 \\
\hline Grout drums & 4.8 \\
\hline Uranium Metal containers & 0.0 \\
\hline $\mathrm{MgF}_{2}$ drums & 0.0 \\
\hline Total Containers Cost & 63.0 \\
\hline \begin{tabular}{|r|} 
Transportation Cost \\
\end{tabular} & \\
\hline Transportation, $\mathrm{U}_{3} \mathrm{O}_{8}$ to NTS & 53.6 \\
\hline Transportation, AHF to Metropolis & 14.9 \\
\hline Transportation, $\mathrm{CaF}_{2}$ to NTS & 2.9 \\
\hline $\begin{array}{l}\text { Transportation, Grouted Neutralization Solids to } \\
\text { NTS }\end{array}$ & 13.4 \\
\hline Transportation, Uranium Metal to NTS & 0.0 \\
\hline Transportation, $\mathrm{MgF}_{2}$ to NTS & 0.0 \\
\hline Total Transportation Costs & 84.7 \\
\hline Disposal Cost & \\
\hline $\mathrm{U}_{3} \mathrm{O}_{8}$ & 36.4 \\
\hline $\mathrm{CaF}_{2}$ & 0.7 \\
\hline Grout & 3.0 \\
\hline Uranium Metal & 0.0 \\
\hline $\mathrm{MgF}_{2}$ & 0 \\
\hline Total Disposal Costs & 40.1 \\
\hline
\end{tabular}

Grand TOTAL LCC 915.3 
Table 3

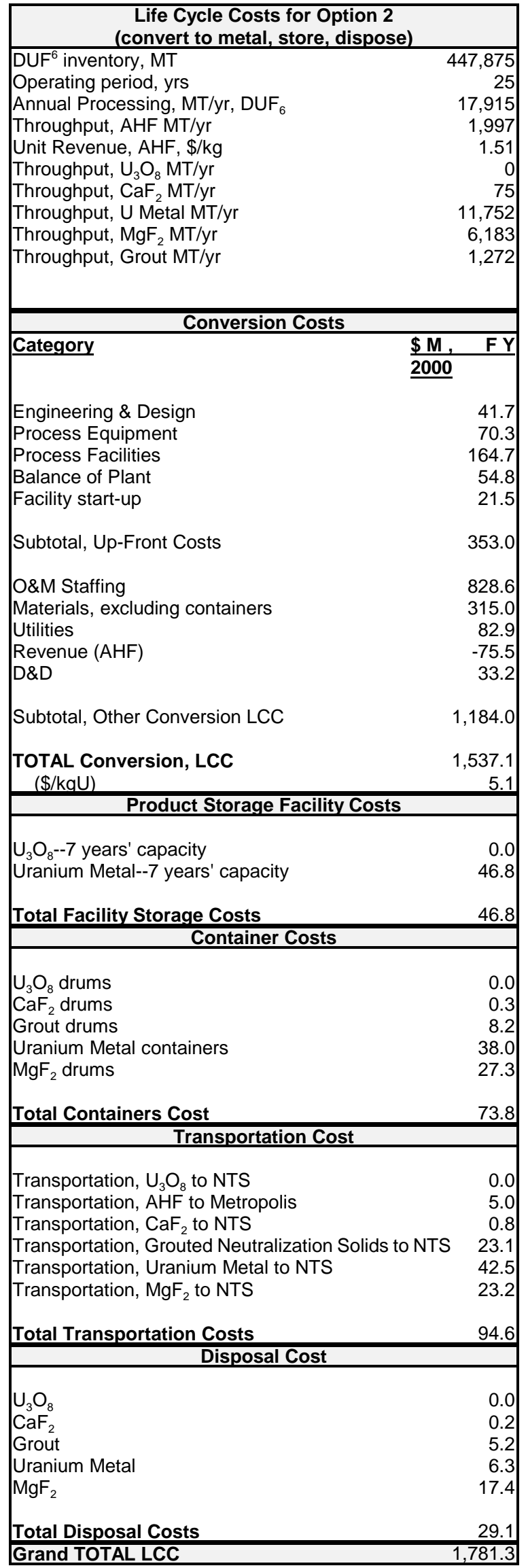


Table 4

\begin{tabular}{|lr|}
\hline \multicolumn{2}{|c|}{ Life Cycle Costs for Option 2p } \\
\hline & \\
\hline & plasma-based conversion to metal, store, dispose) \\
DUF ${ }_{6}$ inventory, MT & 447,875 \\
Operating period, yrs & 25 \\
Annual Processing, MT/yr, $\mathrm{DUF}_{6}$ & 17,915 \\
Throughput, AHF MT/yr & 1,997 \\
Unit Revenue, AHF, $\$ / k g$ & 1.51 \\
Throughput, $\mathrm{U}_{3} \mathrm{O}_{8} \mathrm{MT} / \mathrm{yr}$ & 0 \\
Throughput, $\mathrm{CaF}_{2} \mathrm{MT} / \mathrm{yr}$ & 0 \\
Throughput, $\mathrm{Metal} \mathrm{MT/yr}_{\text {Metal }}$ & 11,752 \\
Throughput, $\mathrm{MgF}_{2} \mathrm{MT} / \mathrm{yr}$ & 0 \\
Throughput, Grout MT/yr & 1,272 \\
\hline
\end{tabular}

\begin{tabular}{|c|c|}
\hline \multicolumn{2}{|c|}{ Conversion Costs } \\
\hline Category & $\$ M, F Y 2000$ \\
\hline \multicolumn{2}{|l|}{$\begin{array}{l}\text { Engineering \& Design } \\
\text { Process Equipment } \\
\text { Process Facilities } \\
\text { Balance of Plant } \\
\text { Facility start-up }\end{array}$} \\
\hline \multicolumn{2}{|l|}{ Subtotal, Up-Front Costs } \\
\hline \multicolumn{2}{|l|}{$\begin{array}{l}\text { O\&M Staffing } \\
\text { Materials, excluding containers } \\
\text { Utilities } \\
\text { Revenue (AHF) } \\
\text { D\&D }\end{array}$} \\
\hline \multicolumn{2}{|l|}{ Subtotal, Other Conversion LCC } \\
\hline $\begin{array}{l}\text { TOTAL Conversion, LCC } \\
(\$ / \mathrm{kgU})\end{array}$ & $\begin{array}{r}587.4 \text { (assumed to be same } \\
1.9 \text { as } \mathrm{U}_{3} \mathrm{O}_{8} \text { conversion) } \\
\end{array}$ \\
\hline \multicolumn{2}{|c|}{ Product Storage Facility Costs } \\
\hline $\begin{array}{l}\mathrm{U}_{3} \mathrm{O}_{8}--7 \text { years' capacity } \\
\text { Uranium Metal--7 years' capacity }\end{array}$ & $\begin{array}{r}0.0 \\
46.8\end{array}$ \\
\hline Total Facility Storage Costs & 46.8 \\
\hline
\end{tabular}

\begin{tabular}{|c|c|}
\hline \multicolumn{2}{|c|}{ Container Costs } \\
\hline $\begin{array}{l}\mathrm{U}_{3} \mathrm{O}_{8} \text { drums } \\
\mathrm{CaF}_{2} \text { drums } \\
\mathrm{Grout} \text { drums } \\
\text { Uranium Metal containers } \\
\mathrm{MgF}_{2} \text { drums }\end{array}$ & $\begin{array}{r}0.0 \\
0.0 \\
8.2 \\
38.0 \\
0.0\end{array}$ \\
\hline Total Containers Cost & 46.2 \\
\hline
\end{tabular}

\begin{tabular}{|lr|}
\hline \multicolumn{2}{|c|}{ Transportation Cost } \\
\hline & \\
Transportation, $\mathrm{U}_{3} \mathrm{O}_{8}$ to NTS & 0.0 \\
Transportation, AHF to Metropolis & 5.0 \\
Transportation, $\mathrm{CaF}_{2}$ to NTS & 0.0 \\
Transportation, Grouted Neutralization Solids to NTS & 23.1 \\
Transportation, Uranium Metal to NTS & 42.5 \\
Transportation, $\mathrm{MgF}_{2}$ to NTS & 0.0 \\
& \\
Total Transportation Costs & 70.6 \\
\hline
\end{tabular}

\begin{tabular}{|lc|}
\hline \multicolumn{2}{|c|}{ Disposal Cost } \\
\hline & \\
$\mathrm{U}_{3} \mathrm{O}_{8}$ & 0.0 \\
$\mathrm{CaF}_{2}$ & 0.0 \\
$\mathrm{Grout}$ & 5.2 \\
Uranium Metal & 6.3 \\
$\mathrm{MgF}_{2}$ & 0.0 \\
& \\
Total Disposal Costs & 11.5 \\
\hline \multicolumn{2}{|l}{} \\
\hline
\end{tabular}


Table 5

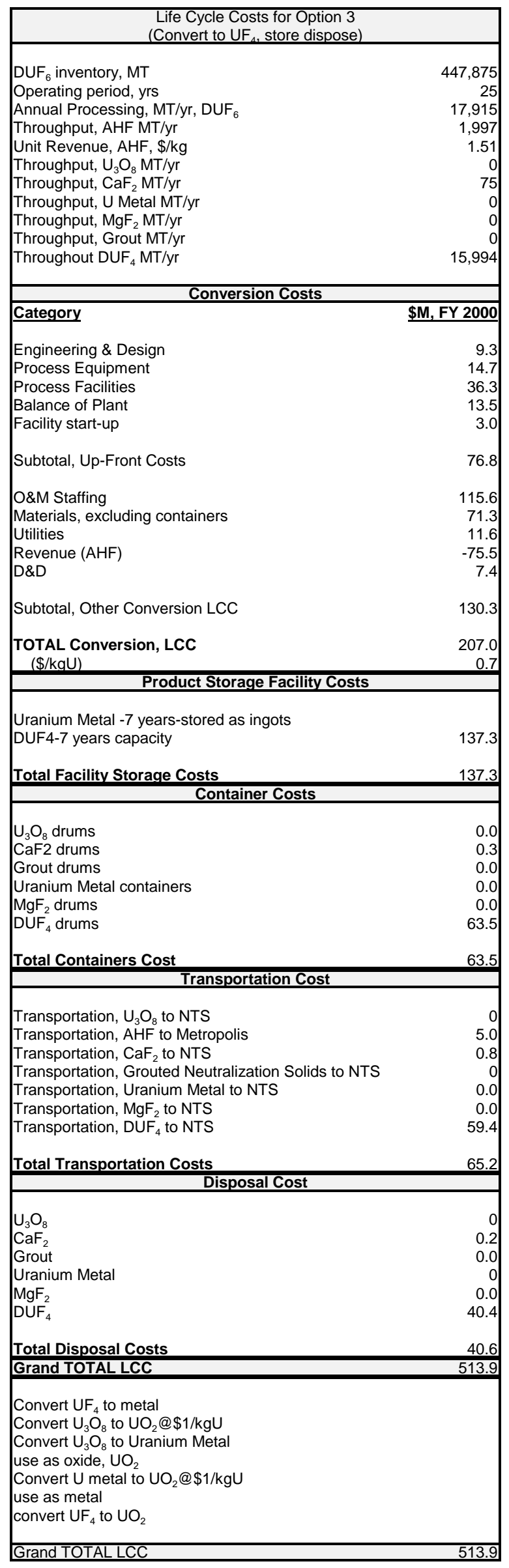




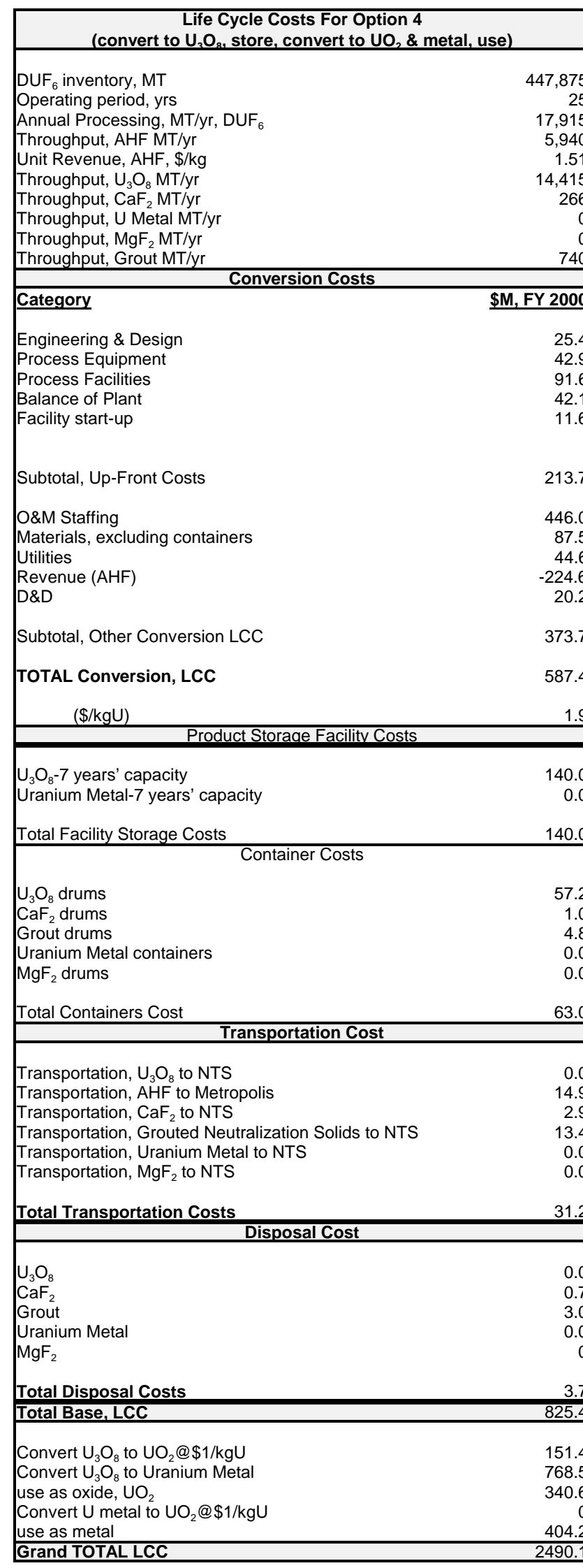




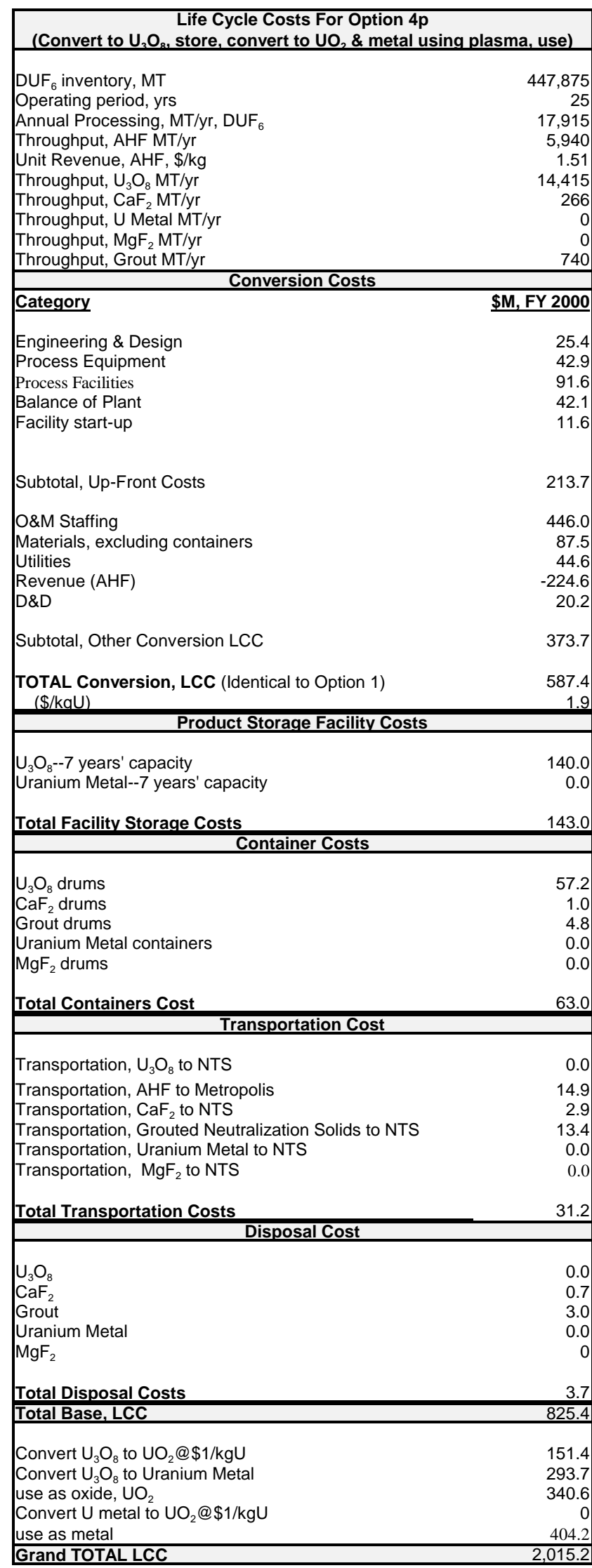

\begin{tabular}{|lrr|}
\hline \multicolumn{2}{|c|}{ Beneficial use } \\
\hline Category & \$M, FY 2000 & \$M, FY 2000 \\
\hline & $50 \%$ & $50 \%$ \\
Engineering \& Design & use as UO2 & use as metal \\
Process Equipment & 9.4 & 10.5 \\
Process Facilities & 17.8 & 18.6 \\
Balance of Plant & 31.0 & 34.5 \\
Facility start-up & 16.2 & 19.6 \\
& 17.9 & 17.9 \\
Subtotal, Up-Front Costs & & 101.0 \\
& 92.4 & 687.4 \\
O\&M Staffing & & 258.5 \\
Materials, excluding containers & 689.1 & 73.5 \\
Utilities & 245.7 & -724.6 \\
Revenue (casks) & 73.7 & 8.3 \\
D\&D & -767.8 & 303.2 \\
Subtotal, Other costs & 7.4 & 404.2 \\
TOTAL Beneficial use Cost & & \\
\hline
\end{tabular}




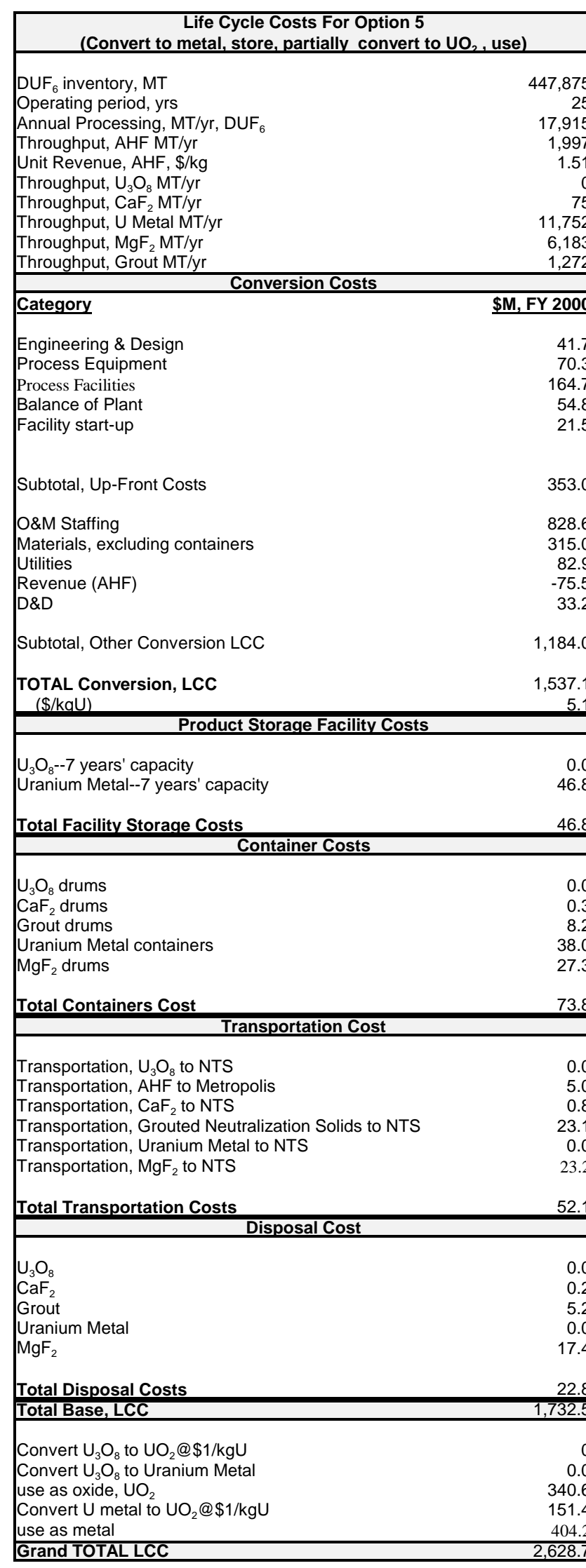




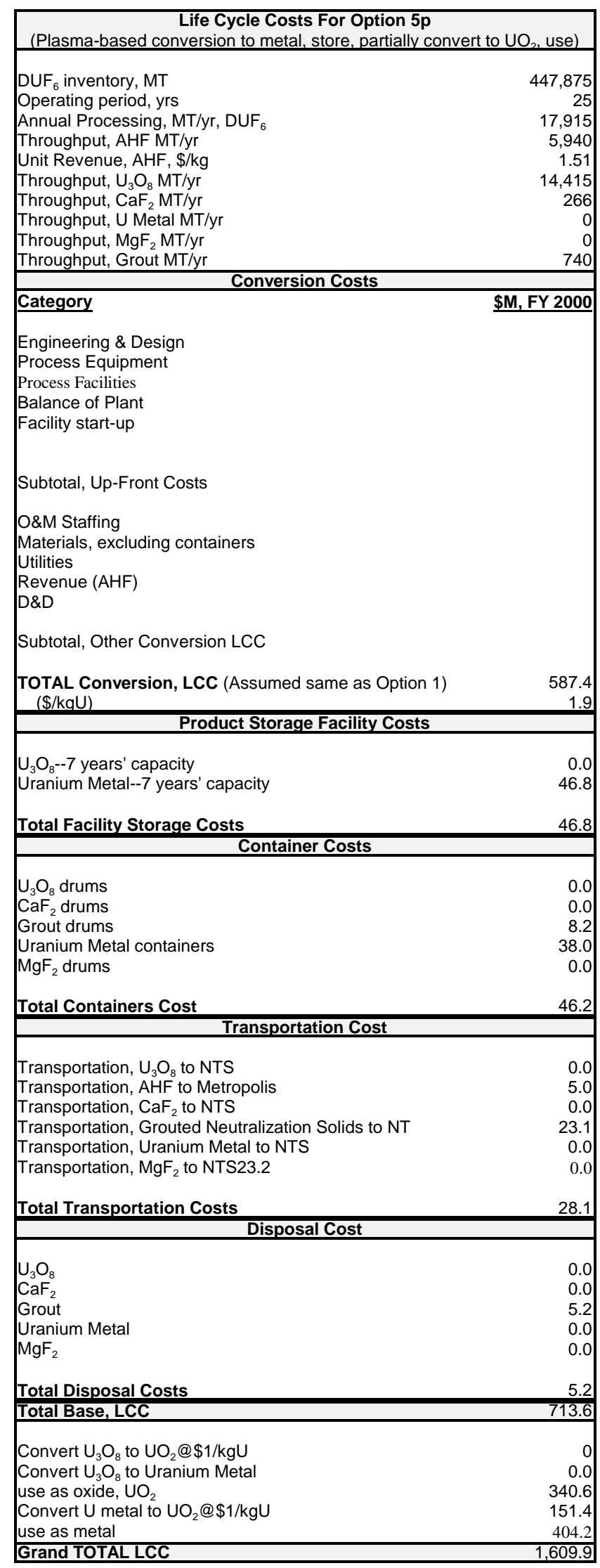

\begin{tabular}{|lrr|}
\hline \multicolumn{3}{c|}{ Beneficial use } \\
\hline Category & $\mathbf{\$ M , \text { FY 2000 }}$ & \$M, FY 2000 \\
\cline { 2 - 3 } & use as UO2 & use as metal \\
Engineering \& Design & 9.4 & 10.5 \\
Process Equipment & 17.8 & 18.6 \\
Process Facilties & 31.0 & 34.5 \\
Balance of Plant & 16.2 & 19.6 \\
Facility start-up & 17.9 & 17.9 \\
Subtotal, Up-Front Costs & & 101.0 \\
O\&M Staffing & 92.4 & \\
Materials, excluding containers & 689.1 & 687.4 \\
Utilities & 245.7 & 258.5 \\
Revenue (casks) & 73.7 & 73.5 \\
D\&D & -767.8 & -724.6 \\
Subtotal, Other costs & 7.4 & 8.3 \\
TOTAL Beneficial use Cost & 248.2 & 303.2 \\
\end{tabular}


Table 10

\begin{tabular}{|c|c|}
\hline $\begin{array}{c}\text { Life Cycle Costs for Option } 6 \\
\text { (Convert to UF } \\
\text { S store, convert to metal and } \cup \text { O }\end{array}$ & nd use) \\
\hline DUF $_{6}$ inventory, MT & 447,875 \\
\hline Operating period, yrs & 25 \\
\hline Annual Processing, MT/yr, DUF 6 & 17,915 \\
\hline Throughput, AHF MT/yr & 1,997 \\
\hline Unit Revenue, AHF, $\$ / \mathrm{kg}$ & 1.51 \\
\hline Throughput, $\mathrm{U}_{3} \mathrm{O}_{8} \mathrm{MT} / \mathrm{yr}$ & 0 \\
\hline Throughput, $\mathrm{CaF}_{2} \mathrm{MT} / \mathrm{yr}$ & 75 \\
\hline Throughput, U Metal MT/yr & 0 \\
\hline Throughput, $\mathrm{MgF}_{2} \mathrm{MT} / \mathrm{yr}$ & 0 \\
\hline Throughput, Grout MT/yr & 0 \\
\hline Throughout DUF ${ }_{4}$ MT/yr & 15,994 \\
\hline \begin{tabular}{|c|c|} 
Conversion Costs \\
\end{tabular} & \\
\hline Category & $\$ M, F Y 2000$ \\
\hline Engineering \& Design & 9.3 \\
\hline Process Equipment & 14.7 \\
\hline Process Facilities & 36.3 \\
\hline Balance of Plant & 13.5 \\
\hline Facility start-up & 3.0 \\
\hline Subtotal, Up-Front Costs & 76.8 \\
\hline O\&M Staffing & 115.6 \\
\hline Materials, excluding containers & 71.3 \\
\hline Utilities & 11.6 \\
\hline Revenue (AHF) & -75.5 \\
\hline $\mathrm{D} \& \mathrm{D}$ & 7.4 \\
\hline Subtotal, Other Conversion LCC & 130.3 \\
\hline TOTAL Conversion, LCC & 207.0 \\
\hline \begin{tabular}{|l|} 
Product Storage Facility Costs \\
\end{tabular} & 0.1 \\
\hline $\begin{array}{l}\text { Uranium Metal }-7 \text { years-stored as ingots } \\
\text { DUF }_{4-7} \text { years capacity }\end{array}$ & 137.3 \\
\hline Total Facility Storage Costs & 137.3 \\
\hline Container Costs & \\
\hline $\begin{array}{l}\mathrm{U}_{3} \mathrm{O}_{8} \text { drums } \\
\mathrm{CaF}_{2} \text { drums } \\
\mathrm{Grout}_{\text {drums }} \\
\text { Uranium Metal containers } \\
\mathrm{MgF}_{2} \text { drums } \\
\mathrm{DUF}_{4} \text { drums }\end{array}$ & $\begin{array}{r}0.0 \\
0.3 \\
6.5 \\
0.0 \\
13.6 \\
63.5\end{array}$ \\
\hline Total Containers Cost & 83.9 \\
\hline Transportation Cost & \\
\hline Transportation, $\mathrm{U}_{3} \mathrm{O}_{8}$ to NTS & 0 \\
\hline Transportation, AHF to Metropolis & 5.0 \\
\hline Transportation, $\mathrm{CaF}_{2}$ to NTS & 0.8 \\
\hline Transportation, Grouted Neutralization Solids to NTS & 18.2 \\
\hline Transportation, Uranium Metal to NTS & 0.0 \\
\hline Transportation, $\mathrm{MgF}_{2}$ to NTS & 11.6 \\
\hline Transportation, DUF $_{4}$ to NTS & 0.0 \\
\hline Total Transportation Costs & 35.7 \\
\hline Disposal Cost & \\
\hline $\begin{array}{l}\mathrm{U}_{3} \mathrm{O}_{8} \\
\mathrm{CaF}_{2} \\
\mathrm{Grout} \\
\text { Uranium Metal } \\
\mathrm{MgF}_{2} \\
\mathrm{DUF}_{4}\end{array}$ & $\begin{array}{r}0 \\
0.2 \\
4.1 \\
0 \\
8.7 \\
0\end{array}$ \\
\hline Total Disposal Costs & 13.0 \\
\hline Grand TOTAL LCC & 476.9 \\
\hline Convert $\mathrm{UF}_{4}$ to metal & 665.0 \\
\hline Convert $\mathrm{U}_{3} \mathrm{O}_{8}$ to $\mathrm{UO}_{2} @ \$ 1 / \mathrm{kgU}$ & \\
\hline Convert $\mathrm{U}_{3} \mathrm{O}_{8}$ to Uranium Metal & 340.6 \\
\hline $\begin{array}{l}\text { Use as oxide, U } 2 \\
\text { Convert U metal to UO } \mathrm{O}_{2} @ \$ 1 / \mathrm{kgU}\end{array}$ & 0 \\
\hline use as metal & 404.2 \\
\hline convert $\mathrm{UF}_{4}$ to $\mathrm{UO}_{2}$ & 387.2 \\
\hline Grand TOTAL LCC & $2,273.9$ \\
\hline
\end{tabular}


Table 11

Life Cycle Cost for Option 7

(Convert to $\mathrm{U}_{3} \mathrm{O}_{8}$ \& metal, store, use)

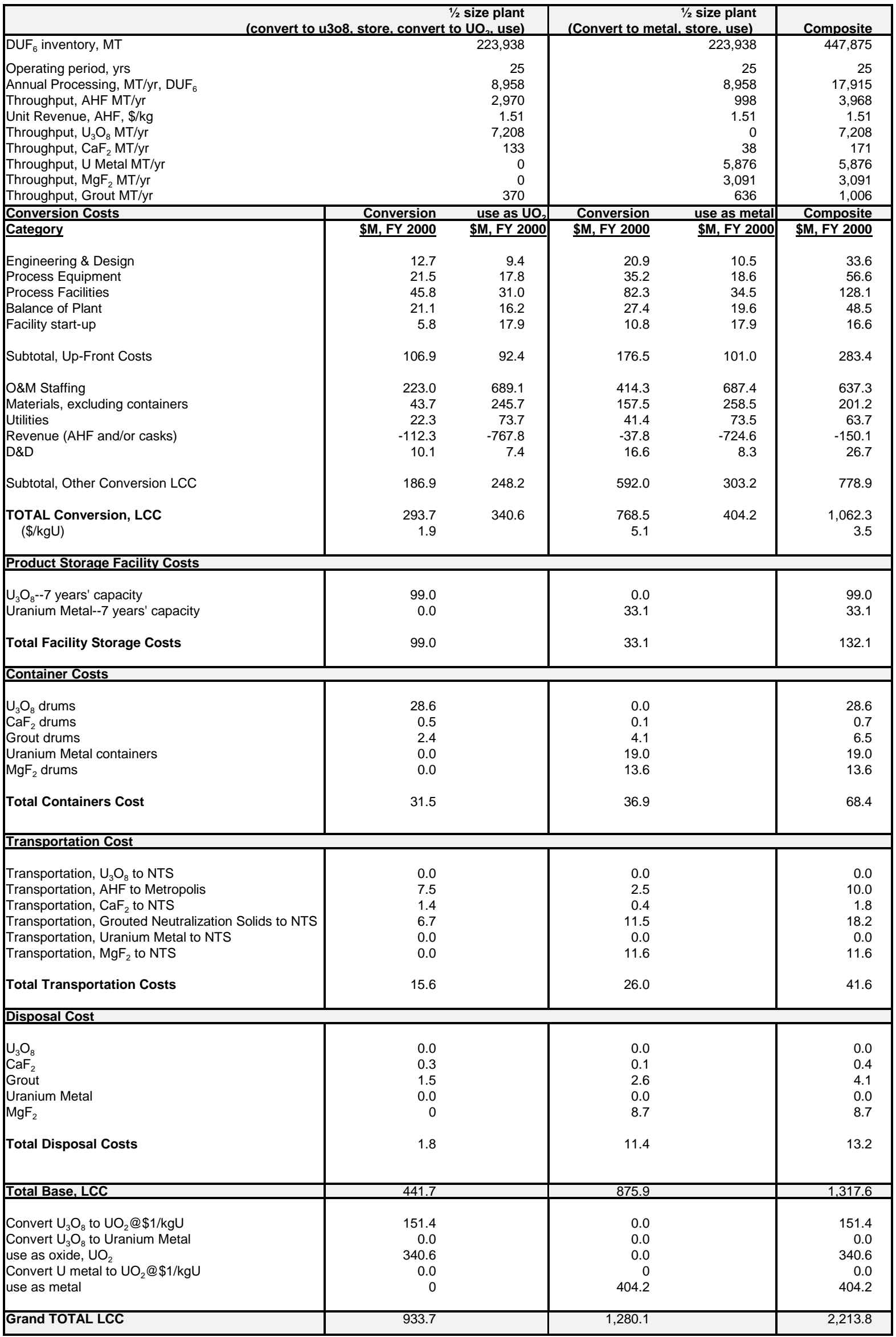


Life Cycle Cost for Option 7p

(Convert to $\mathrm{U}_{3} \mathrm{O}_{8}$, plasma-based conversion to metal, store, use)

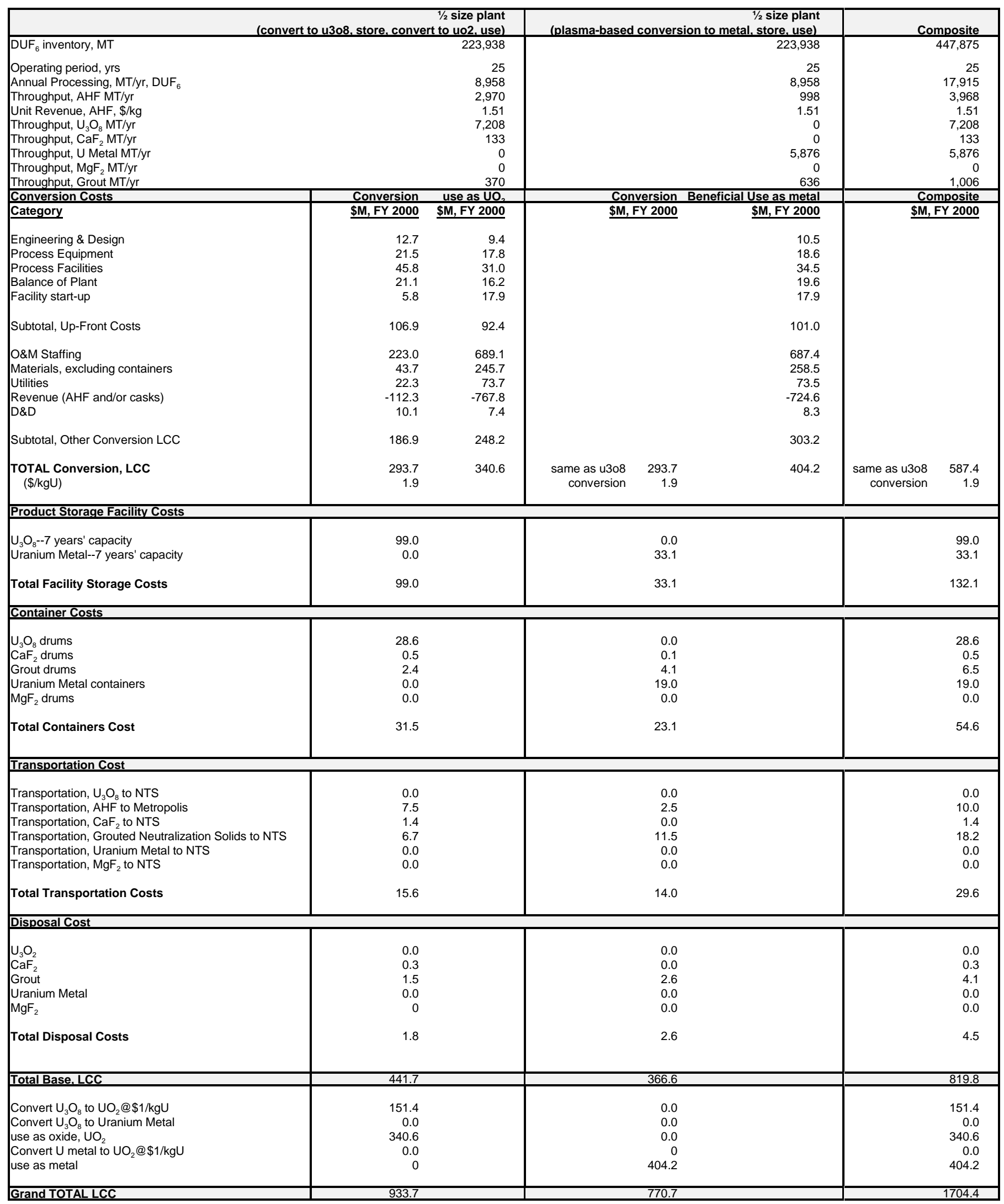


Appendix B

SELECTION OF OPTIMUM STORAGE FORMS FOR DEPLETED URANIUM 


\title{
APPENDIX B \\ SELECTION OF OPTIMUM STORAGE FORMS FOR DEPLETED URANIUM
}

September 3, 1999

\author{
Compiled by: \\ W. K. Duerksen et al. \\ Development Division \\ Oak Ridge Y-12 Plant \\ Oak Ridge, Tennessee
}

For the Trade Study on Depleted Uranium

Storage and Disposal 


\section{CONTENTS}

TABLES . . . . . . . . . . . . . . . . . . . . . . . . . . . . .

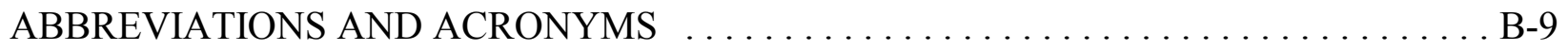

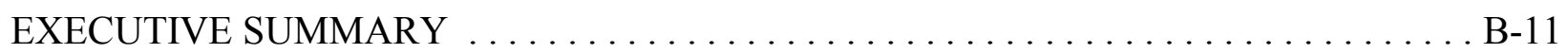



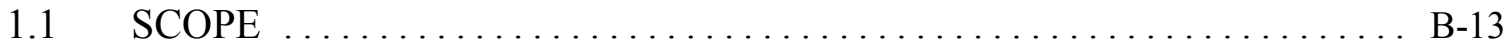

1.2 IDENTIFICATION OF APPLICABLE DOE DOCUMENTS,

ORDERS, STANDARDS, AND GUIDELINES $\ldots \ldots \ldots \ldots \ldots \ldots \ldots$ B-13

2. URANIUM PROPERTIES THAT RELATE TO STORAGE $\ldots \ldots \ldots \ldots \ldots \ldots$ B-17

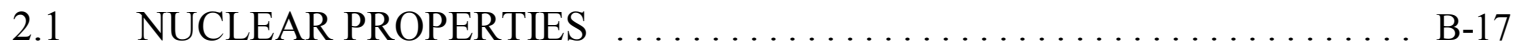

2.1.1 Natural Radioactive Decay ........................ B-17

2.1.2 Shielding and Self-Absorption $\ldots \ldots \ldots \ldots \ldots \ldots \ldots \ldots \ldots \ldots \ldots \ldots \ldots$

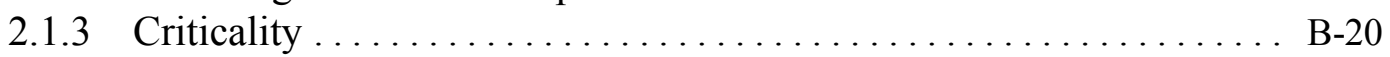

2.1.4 Radon Generation ............................ B-20

2.2 PHYSICAL AND CHEMICAL PROPERTIES OF URANIUM

AND ITS COMPOUNDS $\ldots \ldots \ldots \ldots \ldots \ldots \ldots \ldots \ldots \ldots \ldots \ldots \ldots \ldots \ldots \ldots$

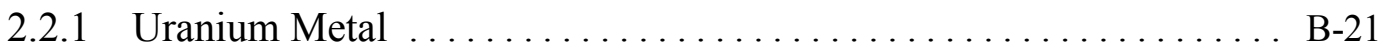

2.2.1.1 Corrosion of metal $\ldots \ldots \ldots \ldots \ldots \ldots \ldots \ldots \ldots \ldots \ldots$ B-22

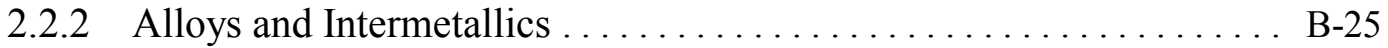

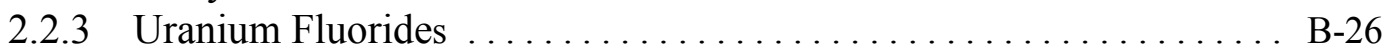

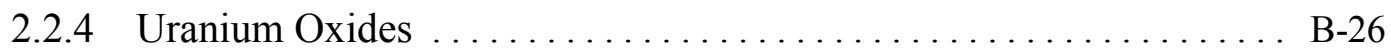

2.3 HEALTH PHYSICS AND INDUSTRIAL HYGIENE $\ldots \ldots \ldots \ldots \ldots \ldots$ B-27

2.3.1 Lung Retention Classification $\ldots \ldots \ldots \ldots \ldots \ldots \ldots \ldots \ldots \ldots \ldots \ldots \ldots \ldots$

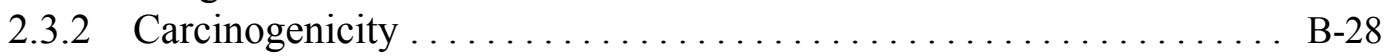

2.3.3 Relative Hazard Potential of Uranium from Radiological

Versus Chemical Toxicity ......................... B-28

2.3.4 Health Physics Considerations ...................... B-29

2.3.5 Industrial Hygiene $\ldots \ldots \ldots \ldots \ldots \ldots \ldots \ldots \ldots \ldots \ldots \ldots \ldots \ldots \ldots \ldots \ldots$

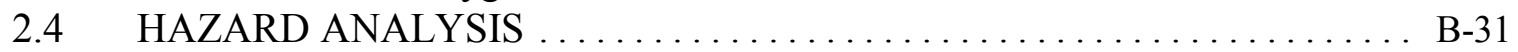

2.5 INFLUENCE OF FABRICATION TECHNOLOGY ON STORAGE FORM B-31

2.5.1 Uranium Metal and Alloy Castings $\ldots \ldots \ldots \ldots \ldots \ldots \ldots \ldots$ B-32

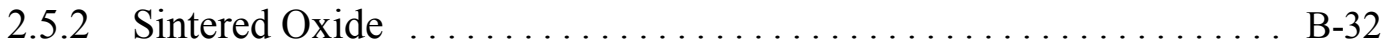

2.6 SELECTION OF THE MOST SUITABLE FORMS FOR STORAGE $\ldots . .$. B-33

3. STORAGE AND DISPOSAL PRACTICES AT DOE FACILITIES $\ldots \ldots \ldots \ldots \ldots$ B-34

3.1 DISPOSAL SITES AT THE OAK RIDGE Y-12 PLANT $\ldots \ldots \ldots \ldots \ldots$ B-34

3.2 DEPLETED URANIUM STORAGE $\ldots \ldots \ldots \ldots \ldots \ldots \ldots \ldots \ldots \ldots \ldots \ldots \ldots \ldots \ldots$

3.2.1 Guidelines for Depleted Uranium Storage Facilities $\ldots \ldots \ldots \ldots \ldots$ B-34

3.2.2 Depleted Uranium Storage Practices .................. B-34

3.2.2.1 Chestnut Ridge (Oxide) Storage Vaults at the Y-12 Plant ........ B-34 
3.2.2.2 Metal Storage Practices at the Y-12 Plant .................. B-35

3.2.2.3 Storage of Metal Derbies at the Fernald

Environmental Management Site .................... B-36

3.2.2.4 Metal Storage Practices at the Savannah River Site .............. B-36

3.2.2.5 Metal Storage Practices at Lawrence Livermore National Laboratory . . B-37

3.3.2.6 Metal Storage Practices at Los Alamos National Laboratory .......... B-37

3.3 USE OF PLASTICS IN THE STORAGE OF DEPLETED URANIUM . . . . . . B-37

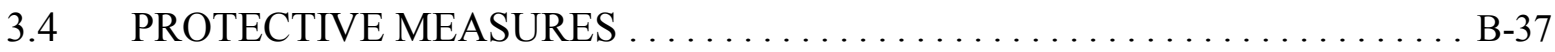

3.5 DEPLETED URANIUM ACCEPTANCE CRITERIA $\ldots \ldots \ldots \ldots \ldots \ldots$. . . 38

4. CONCLUSIONS AND RECOMMENDATIONS FOR EXTENDED STORAGE

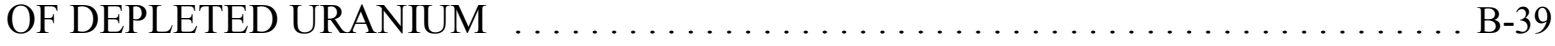

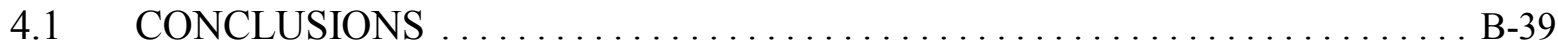

4.2 RECOMMENDATIONS ................................ B-39

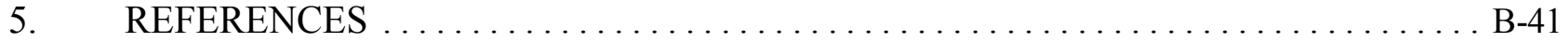

Appendix B.1. FACT SHEET FOR URANIUM METAL AND THE OXIDES $\ldots \ldots \ldots \ldots \ldots$ B-46 


\section{TABLES}

Table Page

1 Federal regulations that pertain to depleted uranium storage facilities B-14

2 U.S. Department of Energy Orders B-14

3 Applicable DOE documents and standards . .

4 Non-governmental publications $\ldots \ldots \ldots \ldots \ldots \ldots \ldots \ldots \ldots \ldots \ldots \ldots \ldots$

$5 \quad$ Initial decay sequences for the natural uranium nuclides $\ldots \ldots \ldots \ldots \ldots \ldots \ldots$ B-18

6 Specific activities of the natural uranium nuclides and selected mixtures . . . . . . B-19

7 Theoretical and bulk densities for uranium and its compounds $\ldots \ldots \ldots \ldots \ldots$ B-21

8 Fundamental properties of uranium metal $\ldots \ldots \ldots \ldots \ldots \ldots \ldots \ldots \ldots \ldots$

9 Rates of reaction of uranium with oxygen and water vapor $\ldots \ldots \ldots \ldots \ldots \ldots$ B-24

10 DACs for natural uranium nuclides $\ldots \ldots \ldots \ldots \ldots \ldots \ldots \ldots \ldots \ldots \ldots$ 


\section{ABBREVIATIONS AND ACRONYMS}

ACGIH American Conference of Governmental Industrial Hygienists

ACL

ALI

ARF

AWRE

$\mathrm{Bq}$

BR

CEDE

CFR

$\mathrm{X} / \mathrm{Q}$

$\mathrm{Ci}$

CRSP

CSMO

DAC

$\triangle \mathrm{T}$

DOE

DR

DU

EPA

HP

IAEA

ICRP

$\mathrm{IH}$

LEL

LMES

MAA

MAR

NRC

$\mathrm{RB}$

$\mathrm{RF}$

SA

SAR

STEL

TLV
Administrative Control Limit

Annual Limit of Uptake

Airborne release fraction

Atomic Energy Research Establishment

Becquerel

Breathing rate

Committed effective dose equivalent

Code of Federal Regulations

(Chi over Q) Atmospheric dilution factor

Curie

Chestnut Ridge Security Pits

Central Scrap Management Office

Derived Air Concentration

Time duration of exposure

U.S. Department of Energy

Damage ratio

Depleted Uranium

U.S. Environmental Protection Agency

Health Physics

International Atomic Energy Agency

International Commission on Radiation Protection

Industrial Hygiene

Lower Explosive Limit

Lockheed Martin Energy Systems, Inc.

Material Access Area

Material at Risk

U.S. Nuclear Regulatory Commission

Relative Kidney Burden

Respirable Fraction

Specific Activity

Safety Analysis Report

Short Term Exposure Limit

Threshold limiting value 


\section{EXECUTIVE SUMMARY}

Several chemical forms of depleted uranium (DU) are reasonably innocuous in terms of their health and safety impact. The pure metal and the triuranium octoxide, $\mathrm{U}_{3} \mathrm{O}_{8}$, are the most suitable for storage in terms of chemical stability. Most common uranium metal alloys are comparable or superior to the pure metal in terms of cohesiveness and resistance to corrosion. However, a potential hazard exists if some $\mathrm{U}-\mathrm{Nb}$ or $\mathrm{U}-\mathrm{Zr}$ alloys are prepared for storage by pickling in nitric acid. An explosive surface layer may form which can detonate even after extended storage. Finely divided uranium is very flammable and can cause serious burns if it ignites, but bulk metal oxidizes rapidly only when heated to very high temperatures. Uranium dioxide, $\mathrm{UO}_{2}$, is chemically quite suitable for long-term storage unless it is in the form of a finely divided, surface-active powder that is potentially pyrophoric. Uranium trioxide, $\mathrm{UO}_{3}$, is also reasonably stable, but tends to form hydrates readily, which could possibly create minor problems in terms of accountability and container corrosion. Uranium tetrafluoride, $\mathrm{UF}_{4}$, is slightly soluble in water and reactive, albeit less so than $\mathrm{UF}_{6}$.

Depleted uranium is not fissile, and has a specific activity that is about two orders of magnitude lower than that of enriched uranium. The external radiation hazard of depleted uranium is minimal due to the low specific activity and the high self-absorption. The primary health/safety hazard associated with the storage of uranium in any chemically non-reactive form is dispersal of the material leading to worker inhalation. Consequently, the physical state of the material in storage is often more important than its chemical state. In the case of bulk uranium metal and alloys, the only significant dispersal mechanism is via corrosion. The corrosion rates of uranium can be calculated from accepted models. For low surface/mass ratios and dry storage conditions, the corrosion rate is low [slightly over one part per million per year] but the net amount of surface oxide is sufficient to require diligence in containment. The oxides, when stored as free-flowing powders, are much more susceptible to dispersal than the metal. Thus oxide powders must be contained in reliable, tightly sealed containers. The most desirable physical form for the oxides is a sintered, full-density ceramic body. The technology for sintering $\mathrm{UO}_{2}$ to this state was developed for fuel rod fabrication. This would be the most desirable form for uranium oxide storage if the sintering process can be done in a cost-effective manner. One option would be to sinter the oxide into large monoliths to fit the available space, floor loading capacity, and material handling resources. A second option would be storage in the form of a gravel or aggregate material, suitable for eventual use in the fabrication of storage and shipping casks for spent fuel and other highly radioactive species.

An effective radiological control program is the most effective means of preventing excessive levels of uranium inhalation or ingestion, regardless of the physical and chemical state of the stored material. In any depleted uranium storage area, regular Health Physics monitoring should be conducted, flammable materials should be excluded and safety work permits should be required prior to any maintenance activity. 


\section{INTRODUCTION}

The purpose of this document is to determine the optimum storage form for depleted uranium (DU) in terms of regulatory constraints, cost, and safety and health factors. The analysis is based on a review of applicable regulations, laws, studies, standards, acceptance criteria [commercial and U.S. Department of Energy (DOE)], past experience with storage, and site plans. The possible storage forms are reviewed, and from this review the preferred storage forms are identified. Current DOE uranium metal storage practice, experience, and standards are described, emphasizing practices at the Oak RidgeY-12 Plant. Current practices for limiting and controlling corrosion of uranium (U) metal in storage are to be reviewed.

Most of the key issues to be addressed in this study have been evaluated previously in an assessment performed at the Y-12 Plant ${ }^{1}$ and in a Criteria Document based on that assessment ${ }^{2}$. Much of the material in this report was taken directly from these two prior documents.

\subsection{SCOPE}

The principal focus of the study is isotopically depleted $U$ (less than $0.72 \%{ }^{235} \mathrm{U}$; unless otherwise noted, all uranium abundance values cited in this report are in atom \%). The study addresses stored material only, and therefore in-process material and material that has been permanently discarded is not considered. All chemical and physical forms fall under the scope of material to be considered, but health and safety considerations may require that many of these be converted to alternate forms for storage. Examples of materials considered to be out-of-scope are irradiated material, isotopically enriched $U$, materials containing the isotopes ${ }^{232} \mathrm{U},{ }^{233} \mathrm{U}$, and ${ }^{236} \mathrm{U}$, and materials whose radioactivity is derived primarily from other nuclides such as fission products, transuranics, and non-naturally occurring $\mathrm{U}$ isotopes.

\subsection{IDENTIFICATION OF APPLICABLE DOE DOCUMENTS, ORDERS, STANDARDS AND GUIDELINES}

Tables 1-4 list the Federal regulations, DOE Orders, standards, applicable DOE documents, and non-governmental publications that were identified in the $\mathrm{Y}-12$ Criteria document $^{2}$ as being pertinent to DU storage. 
Table 1. Federal regulations that pertain to depleted uranium storage facilities

Regulation

Title

10 CFR 830.120

Quality Assurance Rule

10 CFR 835

Occupational Radiation Protection

29 CFR 1910

Occupational Safety and Health Standards

40 CFR 61, Subpart H

Emission Standards

40 CFR 191, Subpart A

Environmental Radiation

Table 2. U.S. Department of Energy (DOE) Orders

Regulation Title (Implementation date)

DOE O $470.1 \quad$ Safeguards and Security Program (September 1995)

DOE 5000.3B Occurrence Reporting and Processing of Operations Information (July, 1993)

DOE 5400.1 General Environmental Protection Program (June 1990)

DOE 5400.5 Radiation Protection the Public and Environment (January 1993)

DOE 5480.7A Fire Protection (February 1993)

DOE 5480.19 Conduct of Operations Requirements for DOE Facilities (May 1992)

DOE 5480.20A Personnel Selection, Qualification, Training, and Staffing at DOE Facilities (November 1994)

DOE 5480.23 Nuclear Safety Analysis Reports (March 1994)

DOE 5500.1B Emergency Management System (February 1992) 
Table 2. (Continued)

\section{Regulation}

Title (Implementation date)

DOE 5500.2B

Emergency Categories, Classes and Notification and Reporting Requirements (February 1992)

DOE 5500.3A Planning and Preparedness for Operational Emergencies (February 1992)

DOE 5500.4A Public Affairs Policy and Planning Requirements for Emergencies (June 1992)

DOE 5500.10

Emergency Readiness Assurance Program (February 1992)

DOE 5633.3B

Control and Accountability of Nuclear Materials (September 1994)

DOE 6430.1A

General Design Criteria (October 1989) ${ }^{\mathrm{a}}$

${ }^{a}$ No longer effective; see DOE Handbook-Design Considerations, DOE-HDBK-1132-99, April 1999, U.S. Department of Energy, Washington, D.C.

Table 3. Applicable DOE documents and standards

\section{Document number}

\section{Title (Implementation date)}

DOE/EH-0256T, Rev. 1 Radiological Control Manual, April 1994

DOE-STD-1071-94 Guideline to Good Practices for Material Receipt, Inspection, Handling, Storage, Retrieval, and Issuance at DOE Nuclear Facilities, June 1994 


\section{Table 4. Non-governmental publications}

Hertzler, T.J., and Nishimoto, D.D., Depleted Uranium Management Alternatives, EGG-MS-11416, Science Application International Corporation, Idaho Falls, ID, December 1993.

Lemons, T.R., et al, The Ultimate Disposition of Depleted Uranium, K/ETO-44, Martin Marietta Energy Systems, Inc., December 1990. 


\section{URANIUM PROPERTIES THAT RELATE TO STORAGE}

\subsection{NUCLEAR PROPERTIES}

Although DU is much less radioactive than some of the materials, such as transuranics and spent reactor fuels, that are also managed by the DOE, the activity level is sufficiently high that attention must be given to radiological control.

\subsubsection{NATURAL RADIOACTIVE DECAY}

Naturally occurring $U$ has an accepted isotopic composition of $99.2739 \pm .0007 \%{ }^{238} \mathrm{U}$, $0.7204 \pm .0007 \%{ }^{235} \mathrm{U}$, and $0.0057 \pm .0002 \%{ }^{234} \mathrm{U}{ }^{3 \mathbf{b}}$ The isotopic composition of depleted material can vary. Typical values for depleted material derived from the "tails" produced by gaseous diffusion are $99.75 \%{ }^{238} \mathrm{U}, 0.25 \%{ }^{235} \mathrm{U}$, and $0.0005 \%{ }^{234} \mathrm{U} .{ }^{3 \mathbf{b}}$ Table A-9 in the Appendix of Ref. 1 shows the complete nuclear decay sequences for the naturally occurring isotopes. The decay products are removed from $\mathrm{U}$ during the chemical processing that precedes metal manufacture. Because highvolume processing of $U$ has been in practice for less than fifty years, significant quantities of nuclides in the decay chains are not present in processed $U$ if they are situated below any long-lived nuclides (say $10^{4}$ or $10^{5}$ year half-lives). In the ${ }^{238} \mathrm{U}^{234} \mathrm{U}$ series, ${ }^{230} \mathrm{Th}$ with a half-life of $8.0\left(10^{4}\right)$ years blocks the buildup of subsequent decay nuclides, while in the ${ }^{235} \mathrm{U}$ series, ${ }^{231} \mathrm{~Pa}$ [half-life of $3.25\left(10^{4}\right)$ years] has this property. The truncated decay sequences shown in Table 5 are convenient for addressing the radiological properties of DU. Some clarification is appropriate regarding the entry for the excited state ${ }^{234 \mathrm{~m}} \mathrm{~Pa}$. The predominant decay mode for this nuclide involves direct decay of the excited state to ${ }^{234} \mathrm{U}$ by beta emission, but a small fraction first converts to ground state ${ }^{234} \mathrm{~Pa}$, which then undergoes beta decay. The latter process involves elevated levels of gamma emission.

The specific activity (SA) of a radionuclide is given by the formula ${ }^{4}$ :

$$
\text { S.A. }=\frac{\operatorname{Ln} 2 \cdot \mathrm{N} \cdot 1}{\tau_{1 / 2}(\mathrm{~s}) \cdot \mathrm{IW}}
$$

Where SA is the specific activity in disintegrations per second per $\mathrm{g}$ or $\mathrm{Bq} / \mathrm{g}, \tau_{1 / 2}(\mathrm{~s})$ is the half-life expressed in seconds, $\mathrm{N}$ is Avogadro's number [6.023 $\left.\left(10^{23}\right)\right]$, and IW is the isotopic weight of the nuclide. The technical literature often uses units of $\mathrm{Ci} \mathrm{(or} \mathrm{microCi)} \mathrm{instead} \mathrm{of} \mathrm{Bq}$ or disintegrations per second). The conversion factor is:

$1 \mathrm{Ci}=3.7\left(10^{10}\right) \mathrm{Bq}=3.7\left(10^{10}\right)$ disintegrations per second.

When half-lives are expressed in years, the specific activities of the radionuclides are given by:

$\mathrm{SA}=1.322\left(10^{16}\right) / \tau_{1 / 2}(\mathrm{y}) \mathrm{Bq}=3.575\left(10^{5}\right) / \tau_{1 / 2}(\mathrm{y}) \mathrm{Ci}$. 


\section{Table 5. Initial decay sequences for the natural uranium series}

Series Nuclear Transition Half-life of parent radionuclide

\begin{tabular}{|c|c|c|}
\hline${ }^{238} \mathrm{U}_{-}{ }^{234} \mathrm{U}$ & ${ }^{238} \mathrm{U} \rightarrow{ }^{234} \mathrm{Th}+{ }^{4} \alpha$ & $4.51\left(10^{9}\right) \mathrm{y}$ \\
\hline & ${ }^{234} \mathrm{Th} \rightarrow{ }^{0} \beta+{ }^{234 \mathrm{~m}} \mathrm{~Pa}$ & $24.1 \mathrm{~d}$ \\
\hline & ${ }^{234 \mathrm{~m}} \mathrm{~Pa} \rightarrow{ }^{0} \beta+{ }^{234} \mathrm{U}$ & $6.75 \mathrm{~h}^{*}$ \\
\hline & ${ }^{234} \mathrm{U} \rightarrow{ }^{4} \alpha+{ }^{230} \mathrm{Th}$ & $2.47\left(10^{5}\right) \mathrm{y}$ \\
\hline${ }^{235} \mathrm{U}$ & ${ }^{235} \mathrm{U} \rightarrow{ }^{4} \alpha+{ }^{231} \mathrm{Th}$ & $7.04\left(10^{8}\right) \mathrm{y}$ \\
\hline & ${ }^{231} \mathrm{Th} \rightarrow{ }^{0} \beta+{ }^{231} \mathrm{~Pa}$ & $25.5 \mathrm{~h}$ \\
\hline & ${ }^{231} \mathrm{~Pa} \rightarrow{ }^{4} \alpha+{ }^{227} \mathrm{Ac}$ & $3.25\left(10^{4}\right) \mathrm{y}$ \\
\hline
\end{tabular}

*A small portion of the ${ }^{234 \mathrm{~m}} \mathrm{~Pa}$ undergoes an intermediate transition to ground state ${ }^{234} \mathrm{~Pa}$. See text.

The specific activities of the three naturally occurring isotopes of $U$ calculated from these formulae are given in Table 6. Specific activities for natural $U$ and typical DU are also shown in the Table. For comparison, the specific activity of ${ }^{239} \mathrm{Pu}$ is $6.20\left(10^{-2}\right) \mathrm{Ci} / \mathrm{g}$, which is higher than the value for DU by more than five orders of magnitude.

\subsubsection{Shielding and Self-Absorption}

Much of the radiation emitted by the radioactive decay of $U$ is attenuated within the bulk of the material itself or in the air between the bulk material and personnel in the area. The magnitude of the effect of shielding can be calculated for the alpha, beta, and gamma radiation emitted by DU. Calculations of the ranges of alpha and beta particles are given in the Appendix of Ref.1. The results may be summarized as follows:

Alpha activity. The range of the alpha particles from DU in air is $3.28 \mathrm{~cm}$, while the range in the $\mathrm{U}$ source is only $4.36\left(10^{-4}\right) \mathrm{cm}$. Therefore: 
Table 6. Specific activities of the natural uranium nuclides and selected mixtures

\section{Specific Activity}

\begin{tabular}{lll} 
Nuclide & $\mathbf{C i} / \mathbf{g}$ & $\mathbf{B q} / \mathbf{g}$ \\
\hline${ }^{234} \mathrm{U}$ & $6.20\left(10^{-3}\right)$ & $2.29\left(10^{8}\right)$ \\
${ }^{235} \mathrm{U}$ & $2.16\left(10^{-6}\right)$ & $7.99\left(10^{4}\right)$ \\
${ }^{238} \mathrm{U}$ & $3.36\left(10^{-7}\right)$ & $1.24\left(10^{4}\right)$ \\
${ }_{\text {Natural } \mathrm{U}^{\mathrm{a}}}$ & $7.02\left(10^{-7}\right)$ & $2.60\left(10^{4}\right)$ \\
Depleted $\mathrm{U}^{\mathrm{b}}$ & $3.64\left(10^{-7}\right)$ & $1.35\left(10^{4}\right)$
\end{tabular}

${ }^{a}$ Calculated for $99.27 \%{ }^{238} \mathrm{U}, 0.7 \%{ }^{235} \mathrm{U}$, and $5.7\left(10^{-3}\right) \%{ }^{234} \mathrm{U}$.

${ }^{\mathrm{b}} \mathrm{Calculated}$ for $99.75 \%{ }^{238} \mathrm{U}, 0.25 \%{ }^{235} \mathrm{U}$, and $5\left(10^{-4}\right) \%{ }^{234} \mathrm{U}$.

1) Nearly all the activity from bulk $U$ is attenuated by self-absorption.

2) Virtually all the alpha activity coming from particles of $U$ that are small enough to be respirable $\left[<4\left(10^{-4}\right) \mathrm{cm}\right]$ will not be self-attenuated. This is the dominant radiological hazard associated with DU. Alternately stated, the internal radiological hazard is much greater than the external radiological hazard.

3) The range of alpha particles in air is less than 1.5 in, so workers are only exposed to alpha activity when they are within 1.5 in of a DU surface.

Beta Activity. The beta activity of $\mathrm{U}$ actually originates with the in-grown decay products ${ }^{234 \mathrm{~m}} \mathrm{~Pa}$ and ${ }^{234} \mathrm{Th}$ from ${ }^{238} \mathrm{U}$ and ${ }^{231} \mathrm{Th}$ from ${ }^{235} \mathrm{U}$. The range of the most energetic of the beta emissions is 0.06 $\mathrm{cm}$ in $\mathrm{U}$ and $926 \mathrm{~cm}$ in air. Actually, the net distance traveled by the beta particles with the highest energy is less than the calculated range because beta particles (unlike alpha particles) are deflected repeatedly during the attenuation process ${ }^{5}$.

Gamma Radiation. Gamma attenuation in a homogeneous medium follows an exponential curve. Therefore, the concept of range is not meaningful in this case. Calculations in the Appendix of Ref. 1 demonstrate that the $U$ gamma intensity decreases by a factor of two for every $7.29 \mathrm{~mm}$ of $U$ traversed, or for every $115 \mathrm{~m}$ of air. 


\subsubsection{Criticality}

The nuclides ${ }^{238} U$ and ${ }^{234} U$ are non-fissile. Because of the low concentration of ${ }^{235} U$ in natural $U$, it is possible to reach a critical configuration only under carefully engineered circumstances, such as moderation by deuterium oxide or reactor-grade graphite. Attaining this type of configuration under random accident conditions is not credible. The possibility is even more implausible when DU is involved instead of normal $\mathrm{U}$.

\subsubsection{Radon Generation}

Inhalation of naturally occurring background levels of radon gas and its decay products has been demonstrated to cause elevated levels of lung cancer. The U.S. Environmental Protection Agency (EPA) estimates that most homes contain $1-2 \mathrm{pCi} / \mathrm{L}$ of radon, and significantly higher levels exist in some homes. The source of this radon is from radioactive decay of $\mathrm{U}$, which occurs in many natural mineral deposits. The reason that radon represents a far more significant health hazard than other radionuclides is the fact that it is an inert gas, and thus is readily liberated from its host matrix at the time of its formation. Inhalation of the radon itself, or of its atomically dispersed decay products, exposes lung tissue to alpha radiation. From the point of view of this study, the question to be addressed is how the background level of radon in a residential dwelling built over typical levels of U-containing minerals compares with that in a storage facility containing many tons of DU. There are two enormous differences between the two situations: 1) there is vastly more U present in a DU storage facility than the subsoil under a typical home, and 2) the DU in storage has undergone chemical processing within the past few decades, and therefore has been isolated from the vast quantities of decay products that grew into $U$ minerals over the geologic time periods since the earth's crust solidified.

In the Appendix of Ref.1, rates of radon formation are calculated for 50-year-old U metal compared to naturally occurring mineral deposits. The results show that the purified material may have a higher rate of radon evolution per unit mass than typical naturally occurring material in the earth's crust. However, the net health impact may actually be less in the former case because of large differences in the isotopic ratios of radon evolved in the two cases.

\subsection{PHYSICAL AND CHEMICAL PROPERTIES OF URANIUM AND ITS COMPOUNDS}

Table 7 shows the theoretical and bulk densities of $U$ metal and several $U$ compounds. Values for the density of the $U$ constituent are also provided for the forms considered most suitable for storage. The theoretical density represents the maximum value obtainable for crystalline forms or for cast/sintered monoliths. The bulk densities for the production forms of $U$ compounds are typically much lower, highly variable, and heavily dependent on the mode of production. Depending on the compound, the physical forms can be microspheres, powders, pellets, or larger aggregates. 
Table 7. Theoretical and bulk densities for uranium and its compounds

\begin{tabular}{|c|c|c|c|c|c|}
\hline \multirow[b]{3}{*}{ Form } & \multirow[b]{3}{*}{ Mol. wt. } & \multicolumn{4}{|c|}{ Density $\left(\mathrm{g} / \mathrm{cm}^{3}\right)$} \\
\hline & & \multicolumn{2}{|c|}{ Theoretical } & \multicolumn{2}{|c|}{ Bulk $^{\mathrm{a}}$} \\
\hline & & Material & $\mathrm{U}^{\mathrm{b}}$ & Material & $\mathrm{U}^{\mathrm{b}}$ \\
\hline $\mathrm{U}$ & 238.03 & 19.05 & 19.05 & 19 & 19 \\
\hline $\mathrm{UF}_{4}$ & 314.02 & 6.70 & 5.08 & $2.0-4.5$ & $1.5-3.4$ \\
\hline $\mathrm{UO}_{2}$ & 270.03 & 10.96 & 9.66 & $2.0-5.0$ & $1.8-4.4$ \\
\hline $\mathrm{UO}_{3}$ & 286.07 & 7.29 & 6.07 & - & - \\
\hline $\mathrm{U}_{3} \mathrm{O}_{8}$ & 842.09 & 8.30 & 7.04 & $1.5-4.0$ & $1.3-3.4$ \\
\hline
\end{tabular}

${ }^{a}$ Bulk densities of $\mathrm{UF}_{4}$ and the oxides are variable, depending on how they are produced. The bulk density cited for $U_{b}$ metal assumes that the material is cast into a monolith that is optimum for storage.

$\mathrm{b}$ The $\mathrm{U}$ density is obtained by multiplying the theoretical density of the compound by the quotient of the atomic weight of $\mathrm{U}$ divided by the molecular weight of the compound.

\subsubsection{Uranium Metal}

Nearly all the DU metal in the DOE inventory was derived from the $\mathrm{UF}_{6}$ by-product of gaseous diffusion, which was converted to metal by sites such as the Fernald Plant near Cincinnati, Ohio. The method of conversion to metal was based on the magnesium $(\mathrm{Mg})$ reduction of "green salt", or $\mathrm{UF}_{4}$, a technology developed at Ames Laboratory in 1942. ${ }^{\mathbf{6 g}, 7,8,9}$ Because of the high temperatures generated in the exothermic reaction, the Mg vapor pressure becomes rather high (4-5 atmospheres), and thus the reduction is conducted in a sealed container. The metal products obtained from the reduction are conventionally known as "derbies".

Uranium is a very dense, lustrous metal. It undergoes two solid-solid phase transformations during heating to the melting point (Table 7). The low-temperature alpha phase is ductile and malleable, the beta phase is brittle, and the high-temperature gamma phase is very plastic ${ }^{\mathbf{1 4 , 1 7}}$. Freshly machined 
surfaces tarnish within a few days, first giving a tan-colored surface layer, later a color usually described as gun-metal blue. Compared to other metals commonly encountered in the workplace, $\mathrm{U}$ is fairly typical except for being very dense and relatively high melting and non-volatile. Table 8 lists some of the basic physical properties of pure U metal.

\subsubsection{Corrosion of Metal}

The primary reason that the corrosion of $\mathrm{U}$ metal is a consideration for storage applications is that the resulting oxide surface layer can become airborne under unfavorable circumstances, resulting in an inhalation hazard. Another reason is that hydrogen formation occurs under some conditions, raising a potential fire and explosion hazard.

The fundamental chemistry underlying $U$ corrosion has been investigated in considerable detail ${ }^{\mathbf{1 8 , 1 9}}$ and several excellent reviews have been compiled ${ }^{18,19 a, 19 g, 19 h, 20 a, 20 b, 21}$. This discussion will be based on the work of A.G. Ritchie, who compiled and correlated the results of numerous investigators ${ }^{18}$. The corrosion reaction of $\mathrm{U}$ with oxygen proceeds according to the equation:

$$
\mathrm{U}+(2+\mathrm{x}) / 2 \mathrm{O}_{2} \rightarrow \mathrm{UO}_{2+\mathrm{x}},
$$

where $\mathrm{x}$ is in the range 0.2 to 0.4 at temperatures below $200^{\circ} \mathrm{C}^{18,19 a, 21}$.

The system of equations that define the rate of corrosion of $U$ fall into four categories: 1) dry air, 2) water vapor at $100 \%$ relative humidity $(\mathrm{RH})$ with no oxygen present, 3 ) water vapor at $100 \% \mathrm{RH}$ in typical atmospheric air $\left(21 \% \mathrm{O}_{2}\right)$, and 4$)$ water vapor at $2-90 \% \mathrm{RH}$ in the presence of oxygen. The equations that pertain under these conditions are presented in Table 9. Qualitatively, the significance of the rate equations is primarily the following points:

- The rates of corrosion in dry air and in normal air (with RH below 90\%) are about the same. However, at higher temperatures, the rate in normal air is significantly higher.

- Corrosion rates at $100 \% \mathrm{RH}$ in normal air are greater than those in dry air or $<90 \% \mathrm{RH}$ air by approximately a factor of twenty.

- Corrosion rates at $100 \% \mathrm{RH}$ in the absence of $\mathrm{O}_{2}$ are about an additional factor of sixty higher.

- When U billets are stored at ambient temperatures under non-condensing humidities, the calculated corrosion rates are very low (typically parts per million).

- Temperature has a large impact on corrosion rates. Calculations for selected systems are given in the Appendix of Ref. 1.

The equations shown in Table 9 represent a very successful correlation of data obtained under carefully controlled experimental conditions by several independent investigators. Nevertheless, if the models are used to predict corrosion rates under actual field conditions, several other factors must be considered: 
Table 8. Fundamental properties of uranium metal

Property (units)

Value

Reference

Temperatures $\left({ }^{\circ} \mathrm{C}\right)$

Melting point

1132.8

$6 a$

Phase transformations
$(\alpha-$ to- $\beta)$
668
$4 \mathrm{a}, 8,12$
$(\beta-$ to- $\gamma)$
775
$4 a, 8,12$

Vapor pressure (p) (atm)
$1720-2340 \mathrm{~K}$
$\log p=-26210 / T(K)+5.92$
$6 a, 10,11$
$1480-2420 \mathrm{~K}$
$\log p=-25230 / T(K)+5.71$
$6 a, 10,12$

Density $\left(\mathrm{g} / \mathrm{cm}^{3}\right)$

$\gamma$ phase @ $25^{\circ} \mathrm{C}$

19.060

6a, 10,13

Crystal modifications
$\alpha$
orthorhombic
13,14
$\beta$
tetragonal
13,14
$\gamma$
bcc
13,14

Heat Capacity $(\mathrm{Cp})\left(\mathrm{J} \cdot \mathrm{K}^{-1} \cdot \mathrm{mol}^{-1}\right)$ 298-941K

$$
\begin{aligned}
\mathrm{Cp}= & 26.92-2.502\left(10^{-3}\right) \mathrm{T}+ \\
& 2.656\left(10^{2}\right) \mathrm{T}^{2}-7.699\left(10^{+4}\right) \mathrm{T}^{-2}
\end{aligned}
$$

14

Enthalpy (J/g)

Fusion
Vaporization

Thermal Conductivity
( $\mathrm{J} \mathrm{mol}^{-1} \mathrm{~s}^{-1} \mathrm{~K}^{-1} @ 70^{\circ} \mathrm{C}$ )
0.29
6a, 16

Electrical Conductivity

$$
\left(\Omega^{-1} \mathrm{~cm}^{-1}\right)
$$

83.4

1883

$3.4\left(10^{4}\right)$
15

15

6a, 10 


\begin{tabular}{|c|c|c|c|}
\hline Environment & Rate equation $^{a}$ & $\begin{array}{c}\text { Temperature } \\
\text { range }\left({ }^{\circ} \mathrm{C}\right)\end{array}$ & $\begin{array}{c}\text { Rate at } \\
\text { 298K }^{\mathrm{a}}\end{array}$ \\
\hline Dry Air & $6.9 \times 10^{8} \mathrm{e}^{-18,300 / \mathrm{RT}}$ & $40-300$ & $2.61\left(10^{-5}\right)$ \\
\hline \multicolumn{4}{|l|}{ Water Vapor } \\
\hline $\begin{array}{r}100 \% \mathrm{RH} \\
\left(\text { no } \mathrm{O}_{2}\right)\end{array}$ & $3.2 \times 10^{8} \mathrm{e}^{-13,800 / \mathrm{RT}}$ & $20-100$ & $2.42\left(10^{-2}\right)$ \\
\hline $\begin{array}{l}100 \% \text { RH } \\
\quad\left(\mathrm{O}_{2} \text { present }\right)\end{array}$ & $4.6 \times 10^{9} \mathrm{e}^{-17,800 / R T}$ & $25-100$ & $4.05\left(10^{-4}\right)$ \\
\hline $\begin{array}{l}\text { 2-90\% RH } \\
\quad\left(\mathrm{O}_{2} \text { present }\right)\end{array}$ & $4.8 \times 10^{13} \mathrm{e}^{-25,000 / R T}$ & $40-130$ & $2.21\left(10^{-5}\right)$ \\
\hline
\end{tabular}

Source: Reference 18.

${ }^{\mathrm{a}} \mathrm{mg}$ of $\mathrm{U}$ reacted per square centimeter of surface per hour; where $\mathrm{R}$ has units of cal $\mathrm{mol}^{-1} \mathrm{~K}^{-1}$; and temperature is measured in $\mathrm{K}$.

1) The rate equations were based on experiments run with machined coupons of metal whose true surface areas are closely approximated by the geometrical surface area. Rough or pitted surfaces will have true surface areas that are much higher than values calculated by making the geometrical approximations, and the actual corrosion rate will be correspondingly higher than the calculated value.

2) The models were developed based on pure $U$ in contact with pure gas phase and pure water vapor. Chloride ion is especially corrosive toward $U$ due to the formation of pits on the metal surface in which localized chloride concentrations drive accelerated redox cell processes. Furthermore, deliquescent salts present on the surface of U metal will significantly enhance moisture condensation. Two specific sources of chloride surface contamination in DU storage areas are fingerprints and airborne dust containing ice-chaser (calcium chloride).

3) Increased acidity accelerates corrosion and hydrogen evolution. Air pollution, such as sulfur dioxide emitted from the combustion of coal is a significant source of acidity in storage areas. 
4) Temperature effects are described by the equations, but it should be noted that the rate increases markedly with temperature. Relatively brief periods of high temperature can contribute a large portion of the net corrosion that occurs over a long time period.

5) The corrosion rate is also altered for metal that is under mechanical stress. An example is stored material that has been welded, which exhibits irregular corrosion patterns in the heataffected zone. ${ }^{20 c, 20 d}$

The corrosion reaction of $U$ with water is

$$
\mathrm{U}+(2+\mathrm{y}) \mathrm{H}_{2} \mathrm{O} \rightarrow \mathrm{UO}_{2+\mathrm{y}}+(2+\mathrm{y}) \mathrm{H}_{2}
$$

where y is between 0.0 and $0.1 .^{18,19 i, 24}$ No detectable hydrogen is formed in the presence of oxygen except under saturated conditions (saturated conditions meaning circumstances that enable water to condense on the metal surface, and thereby limit the transport of oxygen from the gas phase to the metal surface). ${ }^{18,19 b, 19 c, 19 d, 19 e, 19 f}$

Hydrogen generation is, in general, avoided by maintaining $U$ metal under conditions that preclude high temperatures (above $200^{\circ} \mathrm{C}$ ) and high humidity $(>90 \% \mathrm{RH})$. Examples of conditions that should be avoided to prevent hydrogen evolution from $U$ metal are the following:

1) Storage out of doors or in damp indoor environments that permit condensation on the metal surface to occur.

2) Storage of wet sludges and saw fines.

3) Storage of wet or submerged machine chips and turnings.

Realistically, situations are expected to arise in which interim storage of wet material is necessary. In these circumstances, the duration of wet storage should be minimized and the storage containers must be vented to prevent pressurization.

\subsubsection{Alloys and Intermetallics}

Uranium shows only limited solid solubility with most other metals. This is attributed to the fact that the crystal structures of both $\alpha$ - and $\beta$-U are significantly different than most other metals. ${ }^{\mathbf{6 b}, 22}$ Intermetallic compounds are formed with $\mathrm{Al}, \mathrm{As}, \mathrm{Au}, \mathrm{B}, \mathrm{Be}, \mathrm{Bi}, \mathrm{Cd}, \mathrm{Co}, \mathrm{Cr}, \mathrm{Cu}, \mathrm{Fe}, \mathrm{Ga}, \mathrm{Ge}, \mathrm{Hg}, \mathrm{Ir}$, $\mathrm{Mn}, \mathrm{Ni}, \mathrm{Os}, \mathrm{Pb}, \mathrm{Pd}, \mathrm{Pt}, \mathrm{Rh}, \mathrm{Ru}, \mathrm{Sb}$, and $\mathrm{Sn} .{ }^{6 \mathbf{b}, 23,24}$ Uranium alloys that have traditionally been manufactured and fabricated at the Oak RidgeY-12 Plant are those of Nb, Ti, and Nb-Zr. The utility of the alloys are: 1) pure $\mathrm{U}$ is structurally a weak metal, and alloying confers superior mechanical properties; 2) pure $U$ is highly electropositive and thus vulnerable to corrosion, and some of the alloys show superior corrosion resistance.

Properties of specific $U$ alloys are reviewed extensively in the technical literature. ${ }^{19,20}$ Preparing a homogeneous dispersion of the alloying metal in the matrix is a formidable technical challenge. ${ }^{20}$ 
Uranium alloys of technological significance can be divided into two types: 1) low alloys, such as $\mathrm{U}-0.8 \% \mathrm{Ti}$ (called U-three-quarter-Ti), which do not retain a $\gamma$-phase structure when quenched from high temperatures and 2) the higher alloys, such as U-6\% $\mathrm{Nb}$ (called binary alloy) or U-7.5\% $\mathrm{Nb}$ $0.5 \% \mathrm{Zr}$ (mulberry), which do retain a meta-stable $\gamma$-phase structure after quenching [Percentage values cited are weight percents]. ${ }^{20 f}$ The high-temperature oxidation rate of binary alloy is significantly lower than that of pure metal, while $\mathrm{U}-0.8 \% \mathrm{Ti}$ shows an oxidation rate similar to that of pure metal. ${ }^{20 b}$

In terms of most material storage safety considerations, the common alloys have properties that do not differ significantly from pure metal. A very significant exception involves the reaction with nitric acid. Explosive detonations occur when the niobium and zirconium alloys are contacted with nitric acid, while the surface of pure U metal can safely be "pickled" (cleansed of surface oxide) under controlled conditions. . $5,26,27,28$ The difference in behavior is attributed to the preferential dissolution of $\alpha$-phase $U$ metal, leaving behind a finely-divided $\gamma$ phase metal and/or carbide, both of which react violently with nitric acid. This hazard can be avoided if a $\mathrm{HNO}_{3}-\mathrm{HF}$ mixture instead of pure $\mathrm{HNO}_{3}$ is used for cleaning. This is a significant safety issue for storage as well as process operations because the reactive material may explode in either wet or dry states, and in fact dry samples were observed to explode even after being stored for several months. ${ }^{25}$

\subsubsection{Uranium Fluorides}

Uranium tetrafluoride is an important intermediate in the manufacture of uranium metal. It is readily prepared by precipitation from aqueous solutions of tetravalent uranium salts, but a product that is better suited for bomb reduction is obtained by treatment of $\mathrm{UO}_{2}$ with anhydrous hydrogen fluoride at high temperatures. ${ }^{6 e}$ The melting point of $\mathrm{UF}_{4}$ is $960^{\circ} \mathrm{C}$ and the crystal system is monoclinic with a theoretical density of $6.70 \mathrm{~g} / \mathrm{cm}^{3}$ (Table 7). It is described as being nonvolatile, non-hygroscopic, and only very slightly soluble in water. ${ }^{\text {Gh }}$ Therefore, from the point of view of chemical and physical properties, $\mathrm{UF}_{4}$ could be considered a reasonable form in which to store uranium for a long period of time. However, $\mathrm{UF}_{4}$ is observed to evolve fluoride ions, perhaps from chemisorbed hydrogen fluoride (HF), and the fluoride promotes significant corrosion. In addition, $\mathrm{UF}_{4}$ reacts slowly with moisture at ambient temperatures to form $\mathrm{UO}_{2}$ and $\mathrm{HF}$. The reactivity of $\mathrm{UF}_{4}$, although limited, is considered disadvantageous to either prolonged storage or disposal.

The fluorides $\mathrm{UF}_{3}, \mathrm{U}_{2} \mathrm{~F}_{9}, \mathrm{U}_{4} \mathrm{~F}_{17}$, and $\mathrm{UF}_{5}$ have been described in the technical literature. In addition, a large number of uranium-containing ternary fluorides have been reported. Some of these may have a combination of properties that would make them suitable for long-term storage, but none appear to be present in the DOE complex in appreciable quantities or are clearly superior to $\mathrm{UF}_{4}$ for longterm storage. 


\subsubsection{Uranium Oxides}

A wide variety of $U$ oxides have been identified in laboratory studies, ${ }^{6}{ }^{6}$ but only three are formed in significant quantities under normal processing conditions: $\mathrm{UO}_{2}, \mathrm{U}_{3} \mathrm{O}_{8}$, and $\mathrm{UO}_{3}$. The three oxides can be inter-converted by exposure to oxidizing or reducing atmospheres at elevated temperatures.

Uranium dioxide, $\mathrm{UO}_{2}$, can exist in non-stoichiometric form with variable oxygen ratios. At high temperatures $\mathrm{UO}_{2}$ shows a wide homogeneity range, from $\mathrm{UO}_{1.63}$ to $\mathrm{UO}_{2.25}$. Formation at ambient temperatures yields a range of $\mathrm{UO}_{2.00}$ to $\mathrm{UO}_{2.25}$, depending on the relative oxygen/water content of the environment. $\mathrm{UO}_{2}$ is very stable except when it is in the form of a finely divided powder which can undergo spontaneous oxidation in normal air to form the higher oxides.

Triuranium octoxide, $\mathrm{U}_{3} \mathrm{O}_{8}$, is the principal oxide formed by the corrosion of $\mathrm{U}$ metal under ambient atmospheric conditions (unrestricted access to oxygen). The higher oxides, as well as many other $\mathrm{U}$ compounds, decompose to $\mathrm{U}_{3} \mathrm{O}_{8}$ above $650^{\circ} \mathrm{C}$. ${ }^{6 \mathbf{d}, 29}$ This plus the fact that oxygen lost from $\mathrm{U}_{3} \mathrm{O}_{8}$ above $800^{\circ} \mathrm{C}$ is replaced rapidly during cooling in air are the reasons that $\mathrm{U}_{3} \mathrm{O}_{8}$ is the form chosen for the gravimetric analysis of $U^{6 d, 29}$

Uranium trioxide, $\mathrm{UO}_{3}$, can be formed by the thermal decomposition of uranyl nitrate hexahydrate or $\mathrm{U}$ peroxide. It is hygroscopic, ${ }^{\mathbf{2 6}}$ and forms a stable monohydrate. In water, complete conversion to the monohydrate takes only 24 hours. ${ }^{30}$

Uranium peroxide, $\mathrm{UO}_{4} \cdot \mathrm{nH}_{2} \mathrm{O}$, exists only in the hydrated state. Small quantities of the peroxide may be present on the surface of metal that has been cleaned by treatment with carbonate-peroxide solutions.

\subsection{HEALTH PHYSICS AND INDUSTRIAL HYGIENE}

The previous discussion (see Sect. 2.1) demonstrated that DU, even in large quantities, does not pose a major external radiation hazard to workers or the public. The more significant hazards are situations where $U$ or its chemical compounds are ingested or inhaled (internal radiation and chemical toxicity hazards).

\subsubsection{Lung Retention Classification}

The chemical form of $U$ is a major consideration in determining its hazard level both as regards its chemical toxicology and its radiological hazard. ${ }^{3 d}$ High solubility in bodily fluids such as blood and lung fluid greatly reduces the radiological hazard because the dwell time within the primary target organ is much lower than in the case of an insoluble form. On the other hand, a highly soluble form poses an enhanced chemical toxicological hazard to the kidneys, because all ingested (and inhaled) material will be transported to the kidneys within a short time following an accidental exposure. The 
methodology that has been developed to address the solubility issue involves dividing $\mathrm{U}$ compounds into three classes:

2) Class D: Soluble in body fluids within a few days, or less

3) Class W: Soluble in body fluids within weeks

4) Class Y: Soluble in body fluids only after several years.

Examples of Class D materials are $\mathrm{UF}_{6}, \mathrm{UO}_{2} \mathrm{~F}_{2}, \mathrm{UO}_{2}\left(\mathrm{NO}_{3}\right)_{2}, \mathrm{UO}_{2}\left(\mathrm{C}_{2} \mathrm{H}_{3} \mathrm{O}_{2}\right), \mathrm{UO}_{2} \mathrm{Cl}_{2}, \mathrm{UO}_{2} \mathrm{SO}_{4}$, and $\mathrm{UO}_{3}$. Class $\mathrm{W}$ materials include $\mathrm{UF}_{4}, \mathrm{U}_{3} \mathrm{O}_{8}$, unfired $\mathrm{UO}_{2}, \mathrm{UO}_{4} \cdot \mathrm{nH}_{2} \mathrm{O}$, and $\left(\mathrm{NH}_{4}\right)_{\mathrm{x}} \mathrm{U}_{\mathrm{y}} \mathrm{O}_{\mathrm{z}}$. Class $\mathrm{Y}$ materials include $\mathrm{UAl}_{\mathrm{x}}, \mathrm{UC}_{2}, \mathrm{UZr}$, and high-fired $\mathrm{UO}_{2} \cdot{ }^{3 \mathrm{~d}}$ Unfortunately, there are a few discrepancies between the published listings of classifications of the $\mathrm{U}$ compounds. $\mathrm{U}_{3} \mathrm{O}_{8}$ is designated as a Class Y material in Ref. 31 but placed in Class $\mathrm{W}$ in Ref. $3 \mathrm{~d}$. $\mathrm{UO}_{3}$ is listed as being in Class W in Ref. 31 but is assigned to Class D in Ref. 3d. Reference 3d recommends that actual dissolution rate measurements be made in cases where ambiguity exists as to the proper lung retention classification.

\subsubsection{Carcinogenicity}

The standard reference sources for chemical carcinogens ${ }^{32,33}$ categorize potentially carcinogenic materials into three classes:

- $\quad$ Class I (Confirmed Carcinogens)

- $\quad$ Class II (Suspected Carcinogens)

- $\quad$ Class III (Questionable Carcinogens)

Reference 35 lists $U$ and its soluble and insoluble compounds as confirmed human carcinogens, while reference 32 does not list $U$ or any of its compounds in any of the three classes. The Lockheed-Martin Material Safety Data Sheets (MSDSs) ${ }^{34}$ follow the guidance of Ref. 33, and list $\mathrm{U}$ as a carcinogen.

\subsubsection{Relative Hazard Potential of Uranium from Radiological Versus Chemical Toxicity}

The opening paragraphs of the Health Physics Manual of Good Practices for U Facilities ${ }^{3 a}$ states that "the half lives of most of the naturally occurring isotopes of $U$ are very long - so long in fact that chemical toxicity can predominate over the radiological hazard." ${ }^{3 a}$ The question as to whether radiological damage or chemical toxicology poses the greater personnel hazard is governed by three factors: 1) the isotopic enrichment, 2) the chemical form (Classes D, W, or Y as described in Section 2.3.1), and 3) the question as to whether acute or chronic exposures are being considered. For the case of DU having a ${ }^{235} \mathrm{U}$ assay below $0.72 \%$, the delineation is fairly straightforward: chemical toxicity is the limiting hazard for all Class D and Class W chemicals while radiological toxicity is the limiting hazard for all Class Y chemicals, without regard to whether the type of exposure being 
addressed is chronic or acute. ${ }^{3 c}$ This generalization must be applied with some caution. Bulk U metal would be considered a Class Y chemical, but the principal health threat concerns its corrosion product, the U oxide(s), which are usually classified as Class W materials when not high-fired.

\subsubsection{Health Physics Considerations}

The International Commission on Radiation Protection (ICRP) has established limits for concentrations of radionuclides in air within work areas defined in terms of the annual limit of uptake (ALI). The derived air concentration (DAC) for any radionuclide is that concentration in air, which, if breathed by reference man for a working year under conditions of light activity, would result in the uptake of one annual limit of uptake (ALI) by inhalation. ${ }^{35}$

Accepted DAC values for the three isotopes present in DU are tabulated in Table 10.

Standardized computational methods have been developed for estimating the actual radiological dosage to which workers or the public are exposed under postulated conditions. For a worker inside a facility, the radiation dose is given by: ${ }^{36 a}$

$$
\text { Dose }(\mathrm{rem})=\Sigma \mathrm{MAR}_{\mathrm{i}}(\mathrm{g}) \cdot \mathrm{DR}_{\mathrm{i}} \cdot \mathrm{ARF}_{\mathrm{i}} \cdot \mathrm{RF}_{\mathrm{i}} \cdot \mathrm{SA}_{\mathrm{i}}(\mathrm{Ci} / \mathrm{g}) \cdot \mathrm{BR}\left(\mathrm{m}^{3} / \mathrm{s}\right) \cdot \Delta \mathrm{T}(\mathrm{s}) \cdot \mathrm{CEDE}(\mathrm{Rem} / \mathrm{Ci}) / \mathrm{V}\left(\mathrm{m}^{3}\right),
$$

where the summation is taken over all radionuclides (i), and the definitions are as follows:

- $\quad$ MAR is the total mass of material at risk.

- $\quad$ DR is the damage ratio, the fraction of the MAR that is impacted by a postulated event (dimensionless).

- $\quad$ ARF is the airborne release fraction (dimensionless).

- $\quad \mathrm{RF}$ is the respirable fraction, or the fraction that is fine enough to become lodged in lung tissue (dimensionless).

- $\quad \mathrm{SA}$ is the specific activity $(\mathrm{Ci} / \mathrm{g})$; see Table 6.

- $\quad$ BR is the breathing rate (cubic meters per second).

- $\Delta \mathrm{T}$ is the time duration of the exposure (seconds).

- $\quad \mathrm{CEDE}$ is the Committed Effective Dose Equivalent in units of rem/Ci.

- $\mathrm{V}$ is the volume of the facility or of the space in which the material is dispersed.

A similar equation is used to calculate the radiation dose to a person located off-site: ${ }^{36 a}$

$$
\operatorname{Dose}(\operatorname{Rem})=\Sigma \mathrm{MAR}_{\mathrm{i}}(\mathrm{g}) \cdot \mathrm{f}_{\mathrm{i}} \cdot \mathrm{SA}_{\mathrm{i}}(\mathrm{Ci} / \mathrm{g}) \cdot \mathrm{X} / \mathrm{Q}\left(\mathrm{s} / \mathrm{m}^{3}\right) \cdot \mathrm{BR}\left(\mathrm{m}^{3} / \mathrm{s}\right) \cdot \mathrm{CEDE}(\mathrm{Rem} / \mathrm{Ci}),
$$

where, in addition to terms defined above:

- $\quad \mathrm{f}_{\mathrm{i}}$ is the assumed respirable fraction from radionuclide $\mathrm{i}$ in material at risk released outside the facility (dimensionless), and 
- $\quad \mathrm{X} / \mathrm{Q}$ (chi over $\mathrm{Q}$ ) is the assumed atmospheric dilution factor at the location of the target individual ${ }^{37}$ (units of $\mathrm{sec} / \mathrm{m}^{3}$ ).

Sample calculations are given in the Appendix to Ref.1. Values calculated from the dosimetric equations are to be compared with LMES and DOE occupational dose limits and administrative control levels. The current DOE Administrative Control Limit (ACL) is 2000 mrem per year, and the LMES ACL is 1000 mrem/year. ${ }^{38}$

Table 10. DACs for natural uranium nuclides

\begin{tabular}{lcc}
\hline \multirow{2}{*}{ Nuclide } & Retention class & DAC $(\mathrm{Ci} / \mathrm{ml})$ \\
\hline \multirow{2}{*}{${ }^{234} \mathrm{U}$} & $\mathrm{D}$ & $5\left(10^{-16}\right)$ \\
& $\mathrm{W}$ & $3\left(10^{-16}\right)$ \\
& $\mathrm{Y}$ & $2\left(10^{-17}\right)$ \\
${ }^{235} \mathrm{U}$ & $\mathrm{D}$ & $6\left(10^{-16}\right)$ \\
& $\mathrm{W}$ & $3\left(10^{-16}\right)$ \\
& $\mathrm{Y}$ & $2\left(10^{-17}\right)$ \\
${ }^{238} \mathrm{U}$ & $\mathrm{D}$ & $6\left(10^{-16}\right)$ \\
& $\mathrm{W}$ & $3\left(10^{-16}\right)$ \\
& $\mathrm{Y}$ & $2\left(10^{-17}\right)$ \\
\hline
\end{tabular}

$\mathrm{DAC}=$ derived air concentration.

Source for DACs: 10 CFR 835.209,"Concentrations of radioactive material in air," Appendices $\mathrm{A}$ and $\mathrm{C}$.

\subsubsection{Industrial Hygiene}

DOE order 440.1 requires compliance with 29 CFR 1910 and 29 CFR 1926, and with the Threshold Limit Values (TLV) developed by the American Conference of Governmental Industrial Hygienists (ACGIH). The time-weighted average air concentration for $\mathrm{U}$ and its compounds adopted by the ACGIH is $0.2 \mathrm{mg} / \mathrm{m}^{3}$, and the short term exposure limit (STEL) is $0.6 \mathrm{mg} / \mathrm{m}^{3}{ }^{33}$ The latter is the ceiling value considered acceptable for a fifteen-minute (maximum) exposure. The target organ for $\mathrm{U}$ is the kidneys. 
The equations for calculating the intake of $U$ in terms of its non-radiological toxicology are similar in form to those used for calculating the radiation dose. For a worker inside the facility,

$$
\operatorname{Intake}(\mathrm{mg})=\Sigma \mathrm{MAR}_{\mathrm{i}}(\mathrm{g}) \cdot \mathrm{DR}_{\mathrm{i}} \cdot \mathrm{ARF}_{\mathrm{i}} \cdot \mathrm{RF}_{\mathrm{i}} \cdot 1000(\mathrm{mg} / \mathrm{g}) \cdot \mathrm{BR}\left(\mathrm{m}^{3} / \mathrm{s}\right) \cdot \Delta \mathrm{T}(\mathrm{s}) \cdot \mathrm{RB} / \mathrm{V}\left(\mathrm{m}^{3}\right)
$$

where RB is the relative kidney burden. ${ }^{36 a}$ The values recommended for RB in the Highly Enriched Uranium (HEU) Vulnerability Assessment ${ }^{\mathbf{3 6}}$ were 1.0 for Class D materials, 0.2 for Class W materials, and 0.01 for Class Y materials.

In the case of material inhalation by an individual outside the facility, the equation is ${ }^{\mathbf{3 6 a}}$ :

$$
\text { Intake }(\mathrm{mg})=\Sigma \mathrm{MAR}_{\mathrm{i}}(\mathrm{g}) \cdot \mathrm{DR}_{\mathrm{i}} \cdot \mathrm{ARF}_{\mathrm{i}} \cdot \mathrm{RF}_{\mathrm{i}} \cdot 1000(\mathrm{mg} / \mathrm{g}) \cdot \mathrm{X} / \mathrm{Q} \cdot \mathrm{BR}\left(\mathrm{m}^{3} / \mathrm{s}\right) \cdot \mathrm{RB}_{\mathrm{i}}
$$

Calculated intake values may be compared with a value of $300 \mathrm{mg}$ of $U$ in adults which is the accepted LD-50 (lethal dose to 50\% of the population). ${ }^{36 \mathbf{b}}$ The criteria used by the Highly Enriched $U$ Working Group ${ }^{\mathbf{3 6 b}}$ to categorize worker intakes were as follows:1) high, for 120 milligrams or greater, 2) medium, for 12 to $120 \mathrm{mg}$, and 3) low, for 1.2 to $12 \mathrm{mg}$. Thresholds for the public were set a factor of ten lower for each classification.

\subsection{HAZARD ANALYSIS}

A formal Hazard Analysis for the storage of DU was presented in Ref.1. The basis was the TargetBarrier-Hazard methodology described in the DOE HEU Vulnerability Assessment. ${ }^{36}$ The targets were defined to be the workers, the public, and the environment. The analysis did not address general safety issues (i.e., typical industrial accidents) such as falls, electric shock, vehicular accidents, or facility fires that do not directly impact the material in storage.

The most serious hazard was identified as the inhalation or ingestion of the material. This is a valid generalization regardless of whether the dispersed material is hazardous primarily due to its radiological activity or its chemical toxicology. Circumstances that can lead to excessive inhalation include the following:

1) Poor containment of oxide powders.

2) Poor containment of corrosion layers on metals.

3) Metal fires and facility fires, especially if the $U$ is commingled with organic matter, such that $\mathrm{U}$ can become entrained in the gaseous combustion products.

4) Major external disturbances (earthquakes, tornadoes, and aircraft crashes).

In addition to inhalation hazards, other significant hazards identified include burns from U fires, hydrogen fires and/or explosions due to wet storage of $U$, excessive floor loadings where applicable, and detonations resulting from nitric acid pickling. 


\subsection{INFLUENCE OF FABRICATION TECHNOLOGY ON STORAGE FORM}

A judicious choice of the physical form of the $\mathrm{U}$ metal/alloy/oxide in storage can greatly limit its susceptibility to dispersal.

\subsubsection{Uranium Metal and Alloy Castings}

Dispersal from metals and alloys occurs primarily as a result of corrosion. Factors that minimize corrosion are 1) minimizing humidity in the atmosphere, and 2) minimizing the surface area-to-mass ratio. The latter goal is achievable by casting the metal/alloy into large billets, a mature technology. Induction heating is usually preferred. Most $U$ casting is carried out in high-quality graphite molds and dies. Contamination of the product by carbon can be minimized by coating the graphite surfaces with a refractory oxide such as zirconia or yttria. Details are given in Ref. 20. Specific choice of the mass and shape of the billets to be stored is dependent on factors such as rated floor loadings and the availability of lift trucks capable of handling multi-ton loadings.

The advantages of storing $\mathrm{U}$ metal and $\mathrm{U}$ alloys in the form of large cast billets are as follows:

1) Corrosion and dispersal are minimized.

2) Space requirements are minimized.

3) Reliance on containment vessels is minimized.

4) The fire hazard is virtually eliminated.

5) Inventories may be tracked more readily.

The two disadvantages are as follows:

1) The cost of operating the casting facility, and

2) The need to reprocess or dispose of the skull material generated during casting.

A formal cost analysis would be required to determine whether the economic gains associated with lowered storage space requirements will offset the cost of running the casting operation.

\subsubsection{Sintered Oxide}

As in the case of the metal, the physical form that is most satisfactory would be a cohesive, near fulldensity monolith. This is a readily achievable form in the case of $\mathrm{UO}_{2}$, and is attainable by sintering in a controlled atmosphere at $1400^{\circ} \mathrm{C}^{39}$ The technology for fabricating $\mathrm{UO}_{2}$ into materials of welldefined specifications was developed in support of the early nuclear power reactor program. The part would be pre-formed by pressing. A very significant allowance for shrinkage during sintering has to be made. The higher oxides do not sinter to high density ceramics because the temperatures 
that would be required decompose them to $\mathrm{UO}_{2}$. Thus $\mathrm{UO}_{3}$ begins to decompose to $\mathrm{U}_{3} \mathrm{O}_{8}$ at $610^{\circ} \mathrm{C}$ and is completely converted at $745^{\circ} \mathrm{C}$, while $\mathrm{U}_{3} \mathrm{O}_{8}$ begins decomposing to $\mathrm{UO}_{2}$ at $946^{\circ} \mathrm{C} .{ }^{40}$

Apart from storage as monoliths, $\mathrm{UO}_{2}$ might alternately be stored as a gravel or aggregate material. Two major advantages of this approach are as follows:

1) The cost involved in pressing the material to shape is avoided, and

2) $\mathrm{UO}_{2}$ aggregate is an attractive material to be used in the fabrication of shipping casks for highly radioactive materials such as spent fuel rods because of its excellent radiological attenuation properties.

\subsection{SELECTION OF THE MOST SUITABLE FORMS FOR STORAGE}

Based on the above discussion, the DU forms considered most desirable for long-term storage are as follows:

1) Uranium metal in the form of large, full density castings having a low surface area-to-mass ratio.

2) Stable U alloys of this same description. However, alloys of niobium or zirconium that have been pickled in nitric acid (not $\mathrm{HNO}_{3}$-HF) are unacceptable unless it can be shown that the surfaces have been passivated so as to be unsusceptible to detonation.

3) Uranium dioxide $\left(\mathrm{UO}_{2}\right)$ that has been sintered to nearly full density in the form of large monoliths, and

4) Uranium dioxide that has been sintered to nearly full density in the form of a gravel or aggregate.

Three other forms that are nearly as satisfactory except for the fact that they will require some containment to prevent dispersal are as follows:

1) Triuranium octoxide $\left(\mathrm{U}_{3} \mathrm{O}_{8}\right)$ as a free-flowing powder.

2) Uranium dioxide $\left(\mathrm{UO}_{2}\right)$ powder that is demonstrably not ignitable, and

3) Broken U metal and small pieces and parts of metal and the equivalent alloys.

At the present time several significant issues have not been resolved, including the following:

1) The breakdown between material that will disposed of versus utilized.

2) Most desirable chemical forms for disposal and for utilization.

3) Packaging requirements that will pertain to shipping and to acceptance criteria imposed by the receiver, including disposal sites. 


\section{STORAGE AND DISPOSAL PRACTICES AT DOE FACILITIES}

During times when the Oak Ridge Y-12 Plant was involved in high-throughput weapons manufacturing, DU was obtained from outside sources as needed, and scrap was discarded by burial. The end of the cold war and the upgrading of environmental regulations required a complete restructuring of storage and disposal practices.

\subsection{DISPOSAL SITES AT THE Y-12 PLANT}

The Chestnut Ridge Security Pits (CRSP) are located south of the main portion of the Y-12 Plant. ${ }^{41}$ During1973-1988, hazardous wastes were buried in trenches in this area. Over 4,000,000 pounds of $U$ and $U$ alloys were buried, as well as about 4,500,000 pounds of other materials, including significant amounts of thorium and beryllium. ${ }^{42}$ The discarded materials were segregated according to the type of material being disposed of. The separate burial sites can be distinguished, and records are adequate to identify those sites that were used for $U$ disposal. The site lies about 200 feet above the 100-year flood plain of the East Fork of Poplar Creek. Closure of the pits was initiated in 1988 and completed in 1989. A long-term remedial action schedule is given in Ref. 42.

\subsection{DEPLETED URANIUM STORAGE}

\subsubsection{Guidelines for Depleted Uranium Storage Facilities}

The overall principles governing the selection of acceptable sites for storing DU metal are the following:

1) DU is radioactive. Therefore, storage sites should be designated as radiation control areas.

2) DU is non-fissile. It is not necessary for it to be stored in a Material Access Area (MAA) and in fact it is preferable that it not be stored in a MAA to avoid possible crossover situations.

3) Facility fires could result in the dispersal of DU. Therefore DU should not be stored in configurations where it is commingled or collocated with flammable materials.

4) Buildings that are designated for decontamination and decommissioning are not appropriate long-term storage sites for DU.

\subsubsection{Depleted Uranium Storage Practices}

\subsubsection{Chestnut Ridge (Oxide) Storage Vaults at the Y-12 Plant}

Two building (vaults) designed for retrievable storage of $\mathrm{DU}\left(\right.$ as $\mathrm{U}_{3} \mathrm{O}_{8}$ ) are situated at the $\mathrm{Y}-12$ site. These are designated by building numbers $9825-1$ and 9825-2. The two structures are identical, 
being $20-\mathrm{ft}(6.1 \mathrm{~m})$ wide by $20-\mathrm{ft}(6.1 \mathrm{~m})$ deep by $80-\mathrm{ft}(24.4 \mathrm{~m})$ long and having a volume of 32,000 $\mathrm{ft}^{3}\left(907 \mathrm{~m}^{3}\right)$. The structures are partially underground. Material is charged to the vault through openings in the vault ceiling. The vaults are relatively empty at present. The vaults have a ventilation system which is vented for 25-30 minutes prior to a dump or stack monitoring. The stack monitoring is done on a quarterly basis. Hydrogen concentrations are measured to verify that the atmosphere within the vaults is well below the lower explosive limit (LEL).

\subsubsection{Metal Storage Practices at the Y-12 Plant}

The majority of material in storage at the Y-12 Plant is in the form of metal and metal alloys. Storage practices of DU are based on a time-related criteria similar to that used for enriched $U$ wherein storage is categorized as either "interim" or "long-term." Long-term storage covers material requiring no further processing, such as material in the metal form of billets or derbies, that is available for subsequent reuse or disposition. Interim storage includes materials requiring further processing steps such as dismantling (storage as piece parts), declassification, crush/shear, or melting. Material awaiting any of these steps may require temporary storage for an undetermined period of time.

Stored DU metal ranges in form. Derbies, ingot, billets, plate, processing scrap and products are typical. Derbies are the initial form of uranium metal generated by the reduction of $\mathrm{UF}_{4}$, while ingots and billets are forms usually made by a vacuum induction casting process. These latter three forms typically weigh several hundred pounds, but can be produced in smaller forms. Plate and processing scrap metal are a product of rolling operations usually ranging in thickness from 1-2 in down to 1/32 in. DU products include as formed parts and also machined forms. While finely divided DU metal can be pyrophoric, all the abovementioned forms have sufficient bulk such that these are not pyrophoric. DU metal machine turning are considered pyrophoric and are usually immersed in water or mineral oil when generated. However, these are not stored for long periods of time, but instead are converted to oxide or to a stabilized waste form.

The metal is susceptible to oxidization especially when subjected to heat and/or high humidity conditions. Over time, even machined components of DU metal will form an oxide layer on the surface. The oxide formed is nominally adherent. However, depending upon the severity of the oxidization, small amounts of oxide can flake away from the surface or be removed by direct handling. The containment of any loose oxide is accomplished by storing the material in strong/tight metal or wooden boxes.

The metal material is stored in several different types of containers. The container types include fiber drums, wood crates, 30 - and 55-gal steel drums, metal B-24 or B- 25 boxes, tote pans, and metal covered pallets. The greater amount of the metal is stored in drums and tote pans. Tote pans are metal boxes with approximate dimensions of 46 -in by 24 -in by 10 or 20 -in (height). These containers hold approximately $400 \mathrm{~kg}$ or $600 \mathrm{~kg}$ of material respectively. Drums are of carbon steel construction with the larger size (55-gallon) holding up to $400 \mathrm{~kg}$ of material. The metal-covered 
pallet, with approximate dimensions of 46 -in by 32 -in by 34 -in (height), is the primary container for storing the metal billets and holds up to $6000 \mathrm{~kg}$ of metal. All containers provide a degree of physical protection, environmental protection, and confinement but there are no provisions for airtight confinement.

Storage practice is consistent with sound safety, radiological management and as low as reasonably achievable (ALARA) principles. Depleted uranium is a weak alpha source and also emits penetrating beta and gamma radiation. ALARA objectives are met by minimizing personnel exposure to the penetrating beta and gamma radiation by the shielding provided by the boxes and the selection of storage sites not frequently occupied. Storage arrays allow access to the boxes to accommodate identification and annual nuclear materials inventory requirements.

Due to the high density of DU usually the boxes are quite heavy and are moved with cranes and/or fork trucks. Consideration is given to this fact when the boxes are designed, providing attachment points and/or fork truck access for safe handling. The boxes are stored outside, in sea/land containers and in warehouses. Areas currently holding large inventories of DU include Bldgs. 92044, 9201-5, 9201-5N, 9201-4, 9204, 9204-2E, 9206, 9720-5, and some small metal structures known as hutches.

Meaningful cost comparisons between storing metal versus oxide at the Y-12 Plant are not available at present. The fact that the materials are being stored as large numbers of small lots of material in diverse forms and in different facilities confounds any attempt at definitive economic analysis. In a dedicated facility, metal storage would probably be more cost effective simply because its density is greater than that of the oxide (see Table 7), and thus less floor space would be required.

\subsubsection{Storage of Metal Derbies at the Fernald Environmental Management Project}

Storage practices for DU metal in the form of derbies at the Fernald Environmental Management Project are similar to those described above for the Y-12 Plant. Derbies are usually contained in specially designed wooden containers capable of meeting DOT transportation requirements or, when inside buildings, in specifically designed derby racks.

\subsubsection{Metal Storage Practices at the Savannah River Site}

The Savannah River Site does not have a DU storage standard. ${ }^{43}$ Current standard practices evolved from earlier times when DU was temporarily stored as an interim measure. The material is packaged in a steel drum with a plastic liner. The drums are stored in corrugated metal (Butler) style buildings. Some of the drums have been over-packed due to concerns about corrosion and possible leakage. Historically, the drummed material was stored wherever space was available across the site. It is now consolidated in metal storage buildings equipped with a concrete floor that are located in the F Area. Only limited ongoing monitoring is employed. 


\subsubsection{Metal Storage Practices at Lawrence Livermore National Laboratory}

Lawrence Livermore National Laboratory (LLNL) currently maintains an inventory of DU consisting of a few metric tons. Most of the material is in ongoing programmatic use. LLNL does not have a DU storage standard. ${ }^{44}$

\subsubsection{Metal Storage Practices at Los Alamos National Laboratory}

The net inventory of DU at the Los Alamos National Laboratory (LANL) MST-6 organization plus several other areas with small holdings is approximately 50-55 metric tons. ${ }^{45}$ Most of this material is considered "in-process." They provide services to numerous customers and consequently the nature of the material in their inventory is widely varied. Examples include massive solid pieces, box electrodes (stored in piles), plate feed stock (stored in drums), bar ingots from the Rocky Flats site, intermediate parts, some finished parts, solid derby plates, plate from rolling lots, and some chips and turnings awaiting recycle or discard. LANL does not have a standard for DU storage. An additional inventory of approximately 10 tons of DU and 8 tons of natural $\mathrm{U}$ is situated at the criticality facility, nearly all of which is considered in-process material. ${ }^{45}$

\subsection{USE OF PLASTICS IN THE STORAGE OF DEPLETED URANIUM}

The suitability of readily available commercial plastics for the containment of enriched $U$ (EU) was addressed in Ref. 46. Calculations indicated that radiation damage to plastics such as polyethylene and polyvinylchloride over projected storage lifetimes is acceptably low, even when enriched $U$ is considered. ${ }^{46}$ Exposure to direct sunlight is significantly more damaging to most plastics than the radiological impact of DU (or for that matter, of EU). The use of polyethylene sheets to cover billets of DU in storage is recommended as a means of minimizing the dispersal of $U$ corrosion layers if the material is not more adequately contained by some other barrier.

\subsection{PROTECTIVE MEASURES}

The protective measures that are considered essential for a DU storage facility are the following: ${ }^{47}$

Medical Surveillance All employees should receive regularly scheduled physical examinations. The records for all active employees have been electronically scanned, thus making duplicate copies available in remote locations.

Personnel Monitoring Personnel contamination monitoring devices should be situated at the exit point from all radiation areas. Radiation dosimeters should be worn by employees who routinely handle radioactive materials. 
Radiation and Contamination Surveys Radiation and contamination areas should be isolated, clearly marked, and monitored rigorously. Surface contamination levels should be routinely measured in work areas, and results made available to the employees who work in those areas.

Air Quality Maintaining air quality in work areas should be overseen by professional health physicists and industrial hygienists. For work activity that requires use of respirators, employees should be required to complete a respirator training course. Issuance of respirators should be rigorously controlled.

Emergency Response Capability Site Fire Departments and Emergency Response Teams should be capable of responding immediately to any emergency situation that occurs in the DU storage area.

Employee Training Employees who regularly work in areas that would expose them to radiation or radioactive contamination should be required to complete Radiation Worker II training or its equivalent every two years.

General Facility Safety Safety issues at all DU storage areas should be addressed in conjunction with the SAR update program and the site response to the Price-Anderson Act.

\subsection{DEPLETED URANIUM ACCEPTANCE CRITERIA}

The Oak Ridge Y-12 Plant has been designated by the Central Scrap Management Office (CSMO) of DOE as the complex-wide storage facility for EU. Formal criteria have been issued by the Y-12 Plant for acceptance of EU from outside sources. ${ }^{48}$ Requests are often received for storage of DU at the Y-12 Plant as a result of downsizing at DOE facilities. At the present time, formal criteria have not been issued for acceptance of DU. In Ref.1, the following interim criteria for acceptance were proposed:

1) Radiologically, the alpha, beta, and gamma activity shall not be more than twice the levels for pure $\mathrm{U}$ of natural isotopic composition.

2) In terms of non-radiological issues, the basis for acceptance of DU should be taken from Ref. 48. 


\section{CONCLUSIONS AND RECOMMENDATIONS FOR EXTENDED STORAGE OF DEPLETED URANIUM}

\subsection{CONCLUSIONS}

The preceding discussion leads to the following conclusions for establishing requirements for extended of storage of DU.

1. The most desirable chemical forms of $U$ for long-term storage are the pure metal, stable alloys, $\mathrm{U}_{3} \mathrm{O}_{8}$, and $\mathrm{UO}_{2}$, if the latter is demonstrably non-ignitable.

2. The most desirable physical forms of $U$ for long-term storage are:

a) Large cast billets of metal or alloy,

b) $\mathrm{UO}_{2}$ that has been sintered into a monolith of near-theoretical density, and

c) Sintered $\mathrm{UO}_{2}$ in the form of an aggregate.

3. Free flowing $\mathrm{UO}_{2}$ or $\mathrm{U}_{3} \mathrm{O}_{8}$ powders must be contained to prevent their airborne dispersal. Small $\mathrm{U}$ pieces should also be contained to prevent the airborne dispersal of their surface corrosion layers.

4. The long term storage of finely divided $U$ metal is unacceptable.

5. Uranium alloys of niobium and/or zirconium must not be treated with nitric acid before being placed in storage.

\subsection{RECOMMENDATIONS}

The following recommendations are provided for developing an effective storage standard for safe, efficient, storage of DU.

1. All DU storage areas must be maintained as Radiation Areas.

2. Health Physics monitoring of all DU storage areas must be conducted on a routine basis.

3. All DU storage areas must be kept free of flammable materials. The areas must be inspected for possible fire loadings on a regular basis.

4. Any maintenance work in a DU storage area not explicitly covered by procedures must be controlled by a safety work permit to determine whether respirators are to be required.

5. Although radon formation rates from processed DU are demonstrably low, air monitoring should be performed in poorly ventilated DU storage areas.

6. The use of plastic sheeting to cover stored $U$ is recommended as a means of contamination control when the material is not enclosed in a container.

7. Floor loading limitations should be posted and observed in all indoor DU storage areas.

8. The size and shape of cast billets and sintered monoliths should be selected to accommodate floor loading restrictions and to minimize storage space requirements. Minimizing the surface area-to-mass ratio of metal castings lowers the net corrosion rate. 
9. The rate of corrosion of cast metal should be minimized, where practicable, by maintaining a low humidity in the facility. 


\section{REFERENCES}

1. Assessment of Depleted Uranium Storage Safety Issues at the Oak Ridge Y-12 Plant, Y/ES-243, Lockheed Martin Energy Systems, Inc., Oak Ridge, TN, December 1997.

2. Criteria for the Safe Storage of Depleted Uranium at the Oak Ridge Y-12 Plant, Y/ES-244, Lockheed Martin Energy Systems, Inc., Oak Ridge, TN, December 1997.

3. Bryce L. Rich, et al., Health Physics Manual of Good Practices for Uranium Facilities, EGG-2530, Idaho National Engineering Laboratory, Idaho Falls, ID, June 1988.
a. p. $1-1$.
b. p. $2-2$.
c. pp. 2-47 and 2-48.
d. p. 2-36.

4. Assessment of Enriched Uranium Storage Safety Issues at the Oak Ridge Y-12 Plant, Y/ES-014, Lockheed Martin Energy Systems, Inc., Oak Ridge, TN, May 1995.

5. H. Cember, Introduction to Health Physics, 2nd Ed., Pergamon Press, London, 1983.

6. J. J. Katz, G. T. Seaborg, and L. R. Morss, The Chemistry of the Actinide Elements, Second Edition, Chapman and Hall, New York, 1986; and references cited therein.
a. p. 228.
b. pp. 233-244.
c. p. 257.
d. p. 266.
e. p. 304.
f. pp. 298-335.
g. p. 224.
h. pp. 306 and 1500 .

7. H.A. Wilhelm, pp. 162-174 in Proc. 1st Int. Conf. on Peaceful Uses of Atomic Energy, Vol. 8, United Nations, Geneva, 1955.

8. J.C. Warner, Metallurgy of Uranium, Natl. Nucl. En. Ser., Div, IV, 12A, USAEC Technical Information Service, Oak Ridge, TN, 1953.

9. C.D. Herrington and A.E. Ruehle, Uranium Production Technology, Van Nostrand, Princeton, NJ, 1959.

10. F.L. Oetting, M.H. Rand, and R.J. Ackerman, The Chemical Thermodynamics of Actinide Elements and Compounds, part 1, The Actinide Elements, STI/PUB/421/1, IAEA, Vienna, 1976. 
11. A. Pattoret, J. Drowart, and S. Smoes, Trans. Farad. Soc. 65, 98 (1964).

12. R.J. Ackerman and E.G. Rauh, J. Phys. Chem.73, 769 (1967).

13. A.N. Holden, Physical Metallurgy of Uranium, Addison-Wesley Publishing Co., Inc., Reading, MA, 1958.

14. Kirk-Othmer Encyclopedia of Chemical Technology, $3^{\text {rd }}$ Ed., Vol. 23, pp. 510-547, Wiley, New York, 1985.

15. M.A. Filyand and E.I. Semenova, Handbook of the Rare Elements III, Boston Technical Publishers, Inc., Cambridge, MA, 1970.

16. J.L. Weeks, Trans. AIME, J. Metals 203,192 (1955).

17. H. Majors, Jr., et al., Materials Handbook, Part 1, "Properties of Uranium", California Research and Development Co., CA, January 1953.

18. A.G. Ritchie, "A Review of the Rates of Reaction of Uranium with Oxygen and Water Vapor at Temperatures up to $300^{\circ} \mathrm{C}$," Journal of Nuclear Materials 102, 170 (1981).

19. This reference consists of nine separate citations, as follows:

a. C.A. Colmenares, Prog. Solid State Chem. 9, 139 (1975).

b. M.McD. Baker, J.W. Bleloch, L.N. Less, and S. Orman, AWRE Report 040/64, 1964.

c. M.McD. Baker, L. N. Less, and S. Orman, Trans Farad Soc. 62, 2525 (1966).

d. V. J. Corcoran, C. Johnston, W.J. Metcalfe, and J. Thorpe, AWRE Report 042/65, 1965.

e. T. Kondo, E.D. Verink, F.H. Beck, and M.G. Fontana, Corrosion 20, 314 (1964)

f. T. Kondo, F.H. Beck, and M.G. Fontana, Corrosion 30, 330 (1974).

g. J.E. Antill, p.73 in Corrosion, Vol. 5, 2nd Ed., Ed. J.J. Shrier, Butterworths, London, 1976.

h. W.D. Wilkinson, Uranium Corrosion and Alloys, Vol. II, U Metallurgy, Wiley-Interscience, New York, 1962.

i. L.J. Weirick, The Oxidation of Uranium in Low Partial Pressures of Oxygen and Water Vapor at $100^{\circ} \mathrm{C}$, SAND83-0618, Sandia National Laboratories, Albuquerque, NM, June1984.

20. J.J. Burke, D.A. Colling, A.E. Gorum, and J. Greenspan,_Physical Metallurgy of Uranium Alloys, Brook Hill Publishing Co., Chestnut Hill, MA, 1976.

a. S.Orman, "Oxidation of Uranium and Uranium Alloys," p. 815.

b. J.V. Cathcart, "Gaseous Oxidation of Uranium Alloys," p. 775.

c. S.R. Anthony and S. Orman, "Stress Corrosion Cracking of Lean Uranium Alloys," p. 835.

d. N.J. Magnani, "Stress Corrosion Cracking of Uranium Alloys,” p. 935. 
e. J.L. Cadden, N.C. Jessen, and P.S. Lewis, Jr., "Melting and Casting of Uranium Alloys," p. 3.

f. J.F. Boland and D.J. Sandstrom, "Mechanical Fabrication, Heat Treatment, and Machining of Uranium Alloys," p. 109.

21. T.C. Totemeier, A Review of the Corrosion and Pyrophoricity Behavior of Uranium and Plutonium, ANL/ED/95-2, Argonne National Laboratory, Argonne, IL, June 1995.

22. R.W.G. Wyckoff, Crystal Structures, 2nd. Ed., Vol. 1, pp.43-45, Interscience Publishers, New York, 1963.

23. E. C. Beahm, C. A. Culpepper, and O. B. Cavin, "Laves Phases of Uranium and $3 d$ Transition Metals,” J. Less-Common Metals 50, 57-71 (1976).

24. E. C. Beahm and C. A. Culpepper, Actinide-Nickel Laves Phases, JUSAP-6, Japan/U.S. Actinide

Program, Oak Ridge National Laboratory, Oak Ridge, TN, January 1990.

25. R.J. Jackson and W.L. Johns, Explosive Nature of Uranium-Based Niobium Alloys After Immersion in Nitric Acid, RFP-1575, Dow Chemical Co., Golden, CO, December 1970.

26. H.P. Roth, Explosions Occurring During Chemical Etching or Pickling of Uranium-Zirconium Alloys, MITY-1105, Massachusetts Institute of Technology, Cambridge, MA,1952.

27. R.P. Larsen, R.S. Shor, H.M. Feder, and D.S. Flikkema, Study of the Explosive Properties of Uranium-Zirconium Alloys, ANL-5135, Argonne National Laboratory, Argonne, IL, 1954.

28. F.S. Martin and B.O. Field, Reactions of Zirconium and Zirconium-Based Alloys with Nitric and Nitric-Hydrofluoric Acids, UKAEA Report AEREC/R 2692, Atomic Energy Research Establishment, Harwell, England, 1958.

29. O.A. Vita, C.R. Walker, and E. Litteral, Anal. Chim. Acta. 64, 249-257 (1973)

30. G. Brauer, Ed., Handbook of Preparative Inorganic Chemistry, Academic Press, New York, 1965.

31. U.S. Code of Federal Regulations, Part 10, Section 835.1.

32. R.J. Lewis, Sr., Carcinogenically Active Chemicals, A Reference Guide, Van Nostrand Reinhold, New York, 1991. 
33. 1996 TLVs and BEIs (Threshold Limit Values and Biological Exposure Indices), ACGIH Worldwide (American Conference of Governmental Industrial Hygienists), Cincinnati, OH, 1996.

34. Lockheed Martin Energy Systems, Inc., Material Safety Data Sheet; and references cited therein.

35. J.J. Bevelacqua, Contemporary Health Physics, p. 390, Wiley, New York, 1995.

36. Highly Enriched Uranium Working Group Report, DOE/EH-0525, U.S. Department of Energy, Washington, D.C., December 1996.

a. Volume III, Process and Protocol, pp.28-29.

b. Volume III, Process and Protocol, p. 31.

37. Handbook on Atmospheric Diffusion, DOE/TIC-11223, U.S. Department of Energy, Washington, D.C., 1982.

38. Y-12 Radiological Control Manual, Y/DQ-61, Lockheed Martin Energy Systems, Inc., Oak Ridge, TN, September 1995.

39. J. Belle, Uranium Dioxide: Properties and Nuclear Applications, U.S. Atomic Energy Commission, Washington, D.C., 1961; see especially Sect. 7.3.

40. C. Duval, Inorganic Thermogravimetric Analysis, $2^{\text {nd }}$ Ed., Elsevier Publishing Co., Amsterdam, Holland, 1963.

41. Remedial Investigation Work Plan for Chestnut Ridge Operable Unit 1 (Chestnut Ridge Security Pits) at the Oak Ridge Y-12 Plant, Y/OR/01-1173\&D1, Martin Marietta Energy Systems, Inc., Oak Ridge, TN, September 1993.

42. Revised RCRA Closure Plan for the Chestnut Ridge Security Pits, Y/TS-391, Martin Marietta Energy Systems, Inc., Oak Ridge, TN, 1988.

43. Personal communication from Craig Martin, Savannah River Site, Aiken, SC, to Robert J. Hightower, Oak Ridge National Laboratory, Oak Ridge, TN, June 29, 1999.

44. Personal communication from Brent Ives, Lawrence Livermore National Laboratory, Livermore, CA, to W. K. Duerksen, Oak Ridge Y-12 Plant, Oak Ridge, TN, July 8, 1999.

45. Personal communication from Philip Tubesing, Los Alamos National Laboratory, Los Alamos, New Mexico, to W.K. Duerksen, Oak Ridge Y-12 Plant, Oak Ridge, TN, July 8, 1999. 
46. Position Paper: Oak Ridge Y-12 Plant Storage of Uranium in plastics, Y/LB-15,913, Lockheed Martin Energy Systems, Inc., Oak Ridge, TN, July 1995.

47. Profiles of Oak Ridge Y-12 Plant Environmental, Safety, and Health Programs, Y/TS-1341, Lockheed Martin Energy Systems, Inc., Oak Ridge, TN, May 15, 1995.

48. Criteria for Acceptance and Technical Assessment for acceptance of Enriched Uranium at the Y-12 Plant, Y/LB-15,290, Lockheed Martin Energy Systems, Inc., Oak Ridge, TN, April 25, 1996. 


\section{APPENDIX B.1: FACT SHEET FOR URANIUM METAL AND THE OXIDES}

\section{$\underline{\text { General }}$}

1. Depleted uranium is non-fissile.

2. Its specific activity is low (five orders of magnitude below that of ${ }^{239} \mathrm{Pu}$.

3. It poses virtually no external radiation hazard.

4. It is primarily an internal radiological hazard, via inhalation.

\section{Uranium Metal}

5. The density is $19.05 \mathrm{~g} / \mathrm{cm}^{3}$, about twice the atomic $\mathrm{U}$ density of $\mathrm{UO}_{2}$.

6. Melting point is $1132^{\circ} \mathrm{C}$.

7. Finely divided metal is flammable, or even pyrophoric if specific surface area is high enough.

8. Bulk metal does not ignite.

9. Clean metal corrodes slowly under dry air conditions. It corrodes much more rapidly under wet, anaerobic conditions.

10. Uranium forms several alloys with useful metallurgical properties.

11. Can be cast into large billets by well-documented procedures.

\section{The Oxides}

12. $\mathrm{U}_{3} \mathrm{O}_{8}$ is chemically a very stable storage form. $\mathrm{UO}_{2}$ is stable except when its form is a very finely divided powder, in which case it can be pyrophoric.

13. The oxides have higher molar volumes (in terms of $U$ ) than the metal.

14. $\mathrm{UO}_{2}$ can be sintered into a ceramic body of nearly theoretical density. $\mathrm{U}_{3} \mathrm{O}_{8}$ decomposes to $\mathrm{UO}_{2}$ below the sintering temperature. 
Appendix C

EVALUATION OF DEPLETED URANIUM DISPOSAL 


\title{
APPENDIX C. EVALUATION OF DEPLETED URANIUM DISPOSAL
}

\author{
D. W. Lee \\ Energy Division \\ Oak Ridge National Laboratory
}

\section{Introduction}

The feasibility of the disposal of depleted uranium (DU) waste is dependent on meeting the waste acceptance criteria (WAC) for a waste disposal facility. WAC have been developed for all radioactive waste disposal facilities currently in operation. This section considers the WAC for disposal facilities most likely to be utilized for the disposal of DU waste and compares the WAC to the characteristics of the waste forms produced by the various technology alternatives for the conversion of depleted $\mathrm{UF}_{6}\left(\mathrm{DUF}_{6}\right)$ material. Previous disposals of DU waste also are discussed. Future disposal of DU from DOE facilities will be affected by the recent approval of DOE Order 435.1. Consequently, this discussion considers the requirements of the new Order on future DU disposals.

\section{DOE Order 435.1 Requirements}

DOE Order 435.1, Radioactive Waste Management, was approved on July 9, 1999 and replaces DOE Order 5820.2A. The Order applies to all radioactive waste and mixed waste from DOE operations. DOE O 435.1 provides for DU to be managed as low-level waste (LLW). For DUF to be disposed of as LLW at a DOE disposal facility, the waste material must meet the WAC for the disposal facility. The WAC must be based on the performance assessment and composite analysis for the disposal facility. Consequently, the DU material needs to be considered as one of the wastes in the performance assessment and composite analysis. DOE disposal facilities that have considered the disposal of DU as part of the performance assessment and composite analysis and provide for the disposal of DU in the WAC for the disposal facility, and have sufficient disposal capacity to consider accepting converted DUF $_{6}$ wastes are Hanford and Nevada Test Site (NTS). The disposal of uranium waste materials at Hanford is much more restrictive than NTS, because uranium is relatively mobile in Hanford soils. For the purpose of this review, NTS is considered the most appropriate DOE disposal facility for the disposal of converted $\mathrm{DUF}_{6}$ waste.

The disposal of LLW generated by DOE at non-DOE facilities is permitted by the requirements of DOE O 435.1, providing the Field Element Manager approves an exemption for the use of non-DOE facilities. The approval of such an exemption is subject to several requirements that basically mandate the use of DOE disposal facilities unless the use of non-DOE facilities can be justified. The existing non-DOE disposal facility that is licensed for the disposal of LLW and 11e(2) byproduct material, and has been used for the disposal of LLW generated by DOE is the Envirocare of Utah, Inc. facility. For the purpose of this review, Envirocare of Utah is considered the most appropriate non-DOE disposal facility for the disposal of converted $\mathrm{DUF}_{6}$ waste. Other non-DOE facilities may be considered to be appropriate for disposal of converted DUF $_{6}$ waste in the future, but these facilities at present would be unable to accept converted $\mathrm{DUF}_{6}$ waste without additional regulatory actions and approvals for the acceptance of such wastes. 


\section{Nevada Test Site Requirements and Past DU Disposals}

Any disposal of converted DUF $_{6}$ waste at NTS presently would be controlled by the Nevada Test Site Waste Acceptance Criteria Rev. 1 (DOE-NV 1997). This WAC applies to disposal at the Area 3 and 5 disposal facilities at NTS. NTS has accepted DU waste and DU metal for disposal only. NTS cannot accept DU for storage prior to disposal. The WAC reflect the findings of the performance assessments for NTS as well as other operational considerations. The recent approval of DOE O 435.1 is not expected to affect the WAC or the acceptance procedures for NTS, because the requirements for waste acceptance and disposal are addressed by the existing version of the WAC.

Disposal of DU metal as LLW has occurred at NTS in the past. The waste was generated by the Department of the Army and was transferred to the DOE Fernald Site. As a NTS certified shipper, the waste was certified by Fernald, shipped to NTS and disposed of at NTS. The waste materials were classified as a result of their shape. To address the classified shape, the DU metal was encapsulated in concrete prior to shipment, and the waste materials were disposed of in a classified disposal cell at NTS. Coincidentally, the encapsulation of the waste addressed any concerns related to the pyrophoric nature of the waste.

Approximately three years ago, DU saw fines from Lawrence Livermore National Laboratory (LLNL) were disposed of at NTS after treatment at SEG, Inc., where the saw fines were encapsulated into a material matrix. The wastes were certified by LLNL prior to shipment and disposal at NTS. This disposal operation was coordinated with DOE HQ and included the preparation of a policy position paper for the disposal of the encapsulated saw fines. Under DOE Order 5820.2A, which controlled radioactive waste management at the time, pyrophoric wastes were not acceptable for disposal, but flammable wastes that were packaged to be non-flammable were acceptable for disposal. The policy position paper addressed this apparent contradiction and supported the disposal of radioactive wastes packaged in a manner to render the waste package non-flammable. Following this disposal action, the WAC for NTS were revised to permit the disposal of flammable wastes as long as the waste package is certified to be non-flammable.

Current disposal practices at NTS allow for the disposal of DU wastes and DU metal as long as the WAC are met. The WAC include limits on particulates, types of waste packages, waste package weights, waste loading (void space), pyrophoric wastes, and radionuclide concentration that affect the acceptability of wastes. Each of these topics influence the acceptability of converted DUF ${ }_{6}$ for disposal at NTS, and are addressed in the following discussion.

NTS WAC Requirement 3.1.4 limits the quantities of fine particulate wastes such that a waste package may contain no more than $1 \mathrm{wt} \%$ of $<10 \mathrm{~m}^{-6}$-diameter particles, or $15 \mathrm{wt} \%$ of $<200 \mathrm{~m}^{-6}$ diameter particles. Waste that is present in fine particulate form can either be immobilized or secondarily contained (i.e, through the use of over-packed or lined containers, or by encapsulation in plastic) to meet the requirement.

NTS WAC Requirement 3.2.5 specifies the use of three acceptable types of waste packages, which are a 1) 55-gal drum, 2) 4 x4 x 7-ft box, or 3) 4 x 2 x 7-ft box. Alternate packages can be considered, but consultation with NTS is required. Bulk waste can also be considered, but any contamination must be fixed, covered, or contained for safe transfer, which would also require 
consultation with NTS. This NTS WAC Requirement alone is not limiting for the disposal of converted DUF $_{6}$. However, the additional considerations of weight and loading requirements do affect the acceptability of converted $\mathrm{DUF}_{6}$ waste for disposal.

NTS WAC Requirement 3.2.6 limits the maximum weight of a box to $9000 \mathrm{lb}$ and of a drum to $1200 \mathrm{lb}$. This limit does not apply to bulk waste. As a result of specifying the waste package and weight, a waste density is prescribed for packaged wastes. The calculated density is $80.4 \mathrm{lb} / \mathrm{ft}^{3}\left(1.3 \mathrm{~g} / \mathrm{cm}^{3}\right)$ for a full box and $161 \mathrm{lb} / \mathrm{ft}^{3}\left(2.6 \mathrm{~g} / \mathrm{cm}^{3}\right)$ for a half-box or a drum. NTS WAC Requirement 3.2 .7 states that waste packages must be loaded to minimize void space to the extent practical, because of the need to reduce subsidence and enhance the long-term performance of the disposal site. The waste density limits in the NTS WAC are significantly less than the density of DU metal and less than the density of the other proposed converted DUF $_{6}$ waste forms, as shown in Table C.1. Consequently, following the conversion of $\mathrm{DUF}_{6}$, additional treatment or packaging steps would be necessary for the resulting waste form to be acceptable at NTS as packaged waste. The reduction in the overall waste density for DU metal to meet the NTS WAC as packaged waste would be the very difficult as compared to the other proposed waste forms. However, for converted $\mathrm{DUF}_{6}$ as $\mathrm{U}_{3} \mathrm{O}_{8}$, a dilution of the converted waste form by less than a factor of two, perhaps by the blending of the $\mathrm{U}_{3} \mathrm{O}_{8}$ with a stabilizing matrix such as grout or some other contaminated waste material with a lower density, would be sufficient for meeting NTS WAC

Requirements 3.2.5 - 3.2.7.

NTS WAC Requirement 3.1.11 states that waste accepted at NTS must not be pyrophoric and any pyrophoric materials in the waste shall be treated, prepared, and packaged to be non-flammable. This requirement allows that materials that are blended in a hardened concrete matrix are considered to be treated to be non-flammable. The certification of the waste being non-flammable is left to the waste generator, who is obliged to demonstrate, as part of the NTS waste acceptance process, that the waste stream is not pyrophoric. The historical disposals of DU metal and encapsulated DU saw fines at NTS clearly indicate that converted $\mathrm{DUF}_{6}$ can be demonstrated to be non-flammable. However, the waste certification program, waste profile, and sampling and analysis plan to support that demonstration would need to be developed, audited and accepted by NTS. The necessary steps to be taken to meet Requirement 3.1.11 for converted DUF $_{6}$ waste would complement the need to reduce the waste density mentioned above. For potentially pyrophoric wastes, such as DU metal, a careful review of the nonflammable characteristic of the waste stream as part of the NTS Waste Acceptance process should be anticipated. Additionally, the DOT requirements (49 CFR) for shipping converted DUF 6 waste from a DUF $_{6}$ conversion facility to NTS are likely to be more restrictive than NTS WAC Requirement 3.1.11.

Table E-1 in Appendix E of the NTS WAC identifies Radionuclide Action Levels for Waste Characterization and Reporting. Waste streams or waste packages exceeding $1 \%$ of the action levels require the greatest level of characterization and verification. The action level for DU in the NTS WAC is $1.5 \mathrm{Ci} / \mathrm{m}^{3}$. Using a specific activity for DU of $4 \mathrm{E}-7 \mathrm{Ci} / \mathrm{g}$, the activity concentration for DU metal with a bulk density of $1.9 \mathrm{E}+7 \mathrm{~g} / \mathrm{m}^{3}$ is $7.6 \mathrm{Ci} / \mathrm{m}^{3}$. The activity concentration for $\mathrm{U}_{3} \mathrm{O}_{8}$ with a bulk density of $1.5 \mathrm{E}+6$ to $4 \mathrm{E}+6 \mathrm{~g} / \mathrm{m}^{3}$ is $0.6-1.6 \mathrm{Ci} / \mathrm{m}^{3}$. The activity range for $\mathrm{UO}_{2}$ would be slightly higher $(0.8-2.0$ $\left.\mathrm{Ci} / \mathrm{m}^{3}\right)$. This result shows that the activity concentration of the converted DUF $\mathrm{F}_{6}$ material is close to or exceeds the action level for the NTS WAC. At NTS, waste packages exceeding the action levels are managed on a case-by-case basis to ensure the disposals are consistent with the performance assessment. Large volume waste streams, such as the proposed converted DUF $_{6}$ waste stream, would be reviewed in 
Table C.1. Densities of depleted uranium forms compared with limits on densities of wastes placed in containers to be disposed of at the Nevada Test Site

\section{Uranium compound Bulk density $\left(\mathrm{g} / \mathrm{cm}^{3}\right)^{\mathrm{a}}$}

\begin{tabular}{cc}
\hline $\mathrm{UF}_{6}$ & 5.1 \\
$\mathrm{UF}_{4}$ & $2.0-4.5$ \\
$\mathrm{UO}_{2}$ & $2.0-5.0$ \\
$\mathrm{U}_{3} \mathrm{O}_{8}$ & $1.5-4.0$ \\
$\mathrm{U}_{\text {metal }}$ & 19. \\
\hline
\end{tabular}

Type of container Limit on density $\left(\mathrm{g} / \mathrm{cm}^{3}\right)^{\mathrm{b}}$

$\begin{array}{lc}\text { 55-gal drum } & 2.6 \\ 4 \times 2 \times 7 \text {-ft box } & 2.6 \\ 4 \times 4 \times 7 \text {-ft box } & 1.3\end{array}$

${ }^{a}$ Source: Programmatic Environmental Impact Statement for Alternative Strategies for the LongTerm Management and Use of Depleted Uranium Hexafluoride, DOE/EIS-029, April 1999, U.S. Department of Energy, Washington, D.C.

berived from Nevada Test Site Waste Acceptance Criteria, Revision 1, August 1997, DOE/NV-325, U.S. Department of Energy, Nevada Operations Office, Las Vegas, Nevada; see text for derivation.

detail and limitations to the disposal of converted DUF 6 waste could occur. Limitations to the disposal of a DU metal waste stream would be more likely to occur, because of the high activity concentration of DU metal as compared to the NTS action level.

Shipment of converted DUF $_{6}$ waste to NTS for disposal can only occur from DOE/NV approved waste generators. Currently, there are 14 approved generators for disposal at NTS. This list of approved waste generators does not include Oak Ridge, Paducah or Portsmouth. For any of these sites to become approved generators for wastes acceptable for disposal, approval of the site as a waste generator and approval of waste streams by DOE/NV is required. Additionally, pending Records of Decision (RODs) associated with NTS and DOE Waste Management Environmental Impact Statements must be issued by DOE HQ. The dates for issuing the necessary RODs that would allow for any of the sites with current inventories of $\mathrm{DUF}_{6}$ to become approved generators of waste for disposal at NTS are uncertain. 
Given the difficulties as described above in meeting the NTS WAC with the converted DUF 6 waste forms, the significant inventories of converted $\mathrm{DUF}_{6}$ waste to be disposed of, and the limited disposals of converted DUF 6 waste at NTS in the past, a detailed review of the converted DUF $_{6}$ waste stream as part of the NTS waste acceptance process should be expected. Reviews of proposed waste streams by the Waste Acceptance Organization at DOE/NV focus on three specific concerns, which are 1) shipment of the waste, 2) handling of the waste, and 3) long-term performance of the disposed waste. Each of these concerns would need to be fully addressed prior to the disposal of converted DUF 6 waste at NTS.

Disposal of $\mathrm{DUF}_{6}$ conversion products would include the consideration of the appropriate disposal facility at NTS (i.e., Area 3 or Area 5) and the evaluation of the capacity for the selected disposal facility. Area 3 has an area of 20 acres and was constructed in Yucca Flat in two craters formed from the underground testing of nuclear weapons. Three additional craters are associated with Area 3 that have not been developed. Recently, this facility was dedicated to the disposal of uranium wastes from Fernald. One crater has been filled with waste and the second crater is being filled. Area 5 was constructed in Frenchman Flat adjacent to the testing area used for atmospheric tests of nuclear weapons. This facility has received waste from approved generators across the DOE complex. The active area in Area 5 occupies 92 acres. An additional 640 acres is within Area 5 that has not been developed.

Each disposal area has an enormous potential capacity that could be made available for the disposal of waste by developing the NTS disposal sites. The large volumes of DUF $_{6}$ conversion product would require the development of additional capacity at the NTS disposal facilities. The development of additional capacity at NTS for the disposal of $\mathrm{DUF}_{6}$ conversion products constitutes a significant Federal action affecting the environment. Consequently, NEPA documentation would be required that would necessarily involve all concerned stakeholders. Certainly, the State of Nevada would be among the concerned stakeholders, and an Environmental Impact Statement may be required for the disposal of the DUF $_{6}$ conversions products at NTS. In addition to any concerns regarding the development of additional disposal capacity, the selection of the most appropriate disposal area would need to be considered. While Area 5 has more acreage available for development, the subsurface environment at Area 5 is relatively unaffected by nuclear weapons testing. The subsurface environment at Area 3 has been significantly affected by underground nuclear testing. As a result, wastes containing long-lived radionuclides have been preferentially disposed at Area 3 to minimize the potential effects of disposal. The selection of the site for disposal of $\mathrm{DUF}_{6}$ products would be properly addressed as part of the NEPA documentation for the development of additional disposal capacity.

\section{Envirocare of Utah, Inc., Requirements}

Envirocare of Utah, Inc. has a license from the State of Utah to dispose of LLW and a license from the NRC to dispose of 11e(2) by-product material. The license for disposal of LLW includes limits on the average concentration per container of radionuclides acceptable for disposal as waste. The average concentration limit for depleted uranium is $3.7 \mathrm{E}+5 \mathrm{pCi} / \mathrm{g}$. This limit is equivalent to the specific activity of depleted uranium with below average quantities of ${ }^{234} \mathrm{U}$. For $0.2 \%{ }^{235} \mathrm{U}$ in DU material, a typical specific activity is $4 \mathrm{E}+5 \mathrm{pCi} / \mathrm{g}$.

The license for the disposal of $11 \mathrm{e}(2)$ byproduct material at Envirocare of Utah, Inc. has the following requirement for operation of the facility: "Waste with an average concentration above 
$4000 \mathrm{pCi} / \mathrm{g}$ for natural uranium, or for any radionuclide in the radium-226 series; above $60,000 \mathrm{pCi} / \mathrm{g}$ for thorium 230; or above $6,000 \mathrm{pCi} / \mathrm{g}$ for any radionuclide in the thorium series in any truck load or railcar will not be accepted." The concentration limit of $4 \mathrm{E}+3 \mathrm{pCi} / \mathrm{g}$ is two orders of magnitude less than the limit for LLW. Furthermore, disposal of converted $\mathrm{DUF}_{6}$ waste under this license would also require a determination that the converted $\mathrm{DUF}_{6}$ waste could be classified as $11 \mathrm{e}(2)$ by-product material. Consequently, disposal of converted $\mathrm{DUF}_{6}$ waste as $11 \mathrm{e}(2)$ byproduct material would likely be more difficult and restrictive than LLW disposal at Envirocare of Utah, Inc.

The NRC published an Order to Exempt Envirocare of Utah, Inc. from certain NRC licensing requirements for special nuclear material in the Federal Register (64 FR 27826-27827). This order allows Envirocare to possess limited quantities of special nuclear material (SNM). The NRC order permits Envirocare to accept waste containers with uranium enrichment below $10 \%$ and a maximum of 20 percent $\mathrm{MgO}$ having a maximum concentration of ${ }^{235} \mathrm{U}$ of $1900 \mathrm{pCi} / \mathrm{g}$. For wastes with higher enrichments and/or larger quantities of $\mathrm{MgO}$ and beryllium, the maximum concentrations of ${ }^{235} \mathrm{U}$ is more restrictive. The assay of the $\mathrm{DUF}_{6}$ ranges from $<0.2 \%$ to natural enrichment of ${ }^{235} \mathrm{U}$. Thus, the concentration of ${ }^{235} \mathrm{U}$ in converted $\mathrm{DUF}_{6}$ metal could range from $2.2 \mathrm{E}+3$ to $1.6 \mathrm{E}+4 \mathrm{pCi} / \mathrm{g}$. This range is well above the SNM limit for disposal of wastes at Envirocare of Utah, Inc. The concentration of ${ }^{235} \mathrm{U}$ in the oxidized DU waste form $\left(\mathrm{U}_{3} \mathrm{O}_{8}\right)$ would have a lower range, because of waste form, but the reduction would be on the order of 10. Consequently, the disposal of converted DUF 6 at Envirocare of Utah, Inc., would be additionally complicated by the SNM limitations to the license for the disposal of LLW.

\section{Summary and Conclusions}

In summary, although there appears no fundamental reason to prevent depleted uranium forms from being disposed at a government or commercial site, the disposal of large quantities of converted DUF $_{6}$ waste has a number of issues to be addressed before disposal can be accomplished; and the time that may be required for closure on these issues may affect the schedule for initiating disposal

Disposal of converted DUF $_{6}$ waste at DOE disposal facilities raises several issues with respect to compliance with the WAC for the disposal facility. The major issues identified in this review are the level of particulate content, density of the waste form, potential pyrophoric nature of the waste form, concentration of uranium in the waste form, the approvals required to ship converted DUF $_{6}$ waste to a DOE disposal facility, and the available disposal capacity for $\mathrm{DUF}_{6}$ conversion products at a DOE disposal facility. Of the proposed waste forms, these issues may be more difficult to resolve for DU metal. For an oxidized waste form, substantial efforts would be required to resolve these issues satisfactorily. Disposal of converted DUF 6 at non-DOE disposal facilities requires the approval of an exemption for the use of non-DOE facilities by the Field Element Manager, which is subject to several requirements, under DOE O 435.1. In addition to issues associated with the approval of such an exemption for converted $\mathrm{DUF}_{6}$ disposal, there are several issues related to the disposal of converted DUF $_{6}$ at commercial disposal facilities. The major issues for the commercial disposal of DUF $_{6}$ are the concentration of uranium in the waste form and the SNM content in the waste form. Other issues related


the pyrophoric nature of the waste form, and the necessary approvals to ship waste. These issues are substantially more difficult to resolve than the similar issues at DOE disposal facilities.

In conclusion, the disposal of converted $\mathrm{DUF}_{6}$ cannot be assured at this time, independent of the selection of the conversion products currently being considered. None of the alternative $\mathrm{DUF}_{6}$ conversion 
products produce a waste form that meets exactly the existing WAC without additional waste treatment or the development of other waste management alternatives. The following are actions that must be completed before disposal at NTS can be accomplished:

1. Initiate negotiations with the Waste Management Organization at DOE/NV to:

a. evaluate whether the DU should be targeted for Area 3 or Area 5 at NTS,

b. evaluate the need to increase NTS disposal capacity to accommodate the large quantities of DU form to be disposed, and

c. review waste streams (product forms) and characteristics and evaluate the ability to meet the WAC directly or develop the necessary justification for exemptions.

2. Initiate the process to achieve approved shipper status to NTS.

3. Complete the existing NEPA documentation for the NTS and DOE Waste Management EIS, and initiate the additional NEPA documentation required for disposal of all $\mathrm{DUF}_{6}$ conversion alternatives. 
Appendix D

DEPLETED URANIUM DISPOSAL FEASIBILITY ASSESSMENT 


\section{APPENDIX D}

\section{DEPLETED URANIUM DISPOSAL FEASIBILITY ASSESSMENT}

B.M. Biwer, N.L. Ranek, M. Goldberg, and H.I. Avci

Environmental Assessment Division

Argonne National Laboratory

Argonne, IL

August 31, 1999 


\section{TABLE OF CONTENTS}

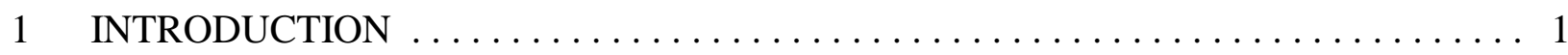

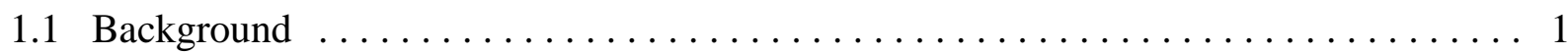

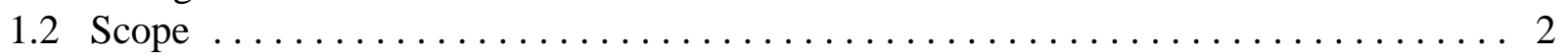

2 DEPLETED URANIUM PROPERTIES AND POTENTIAL WASTE FORMS $\ldots \ldots .4$

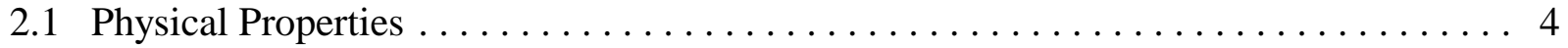

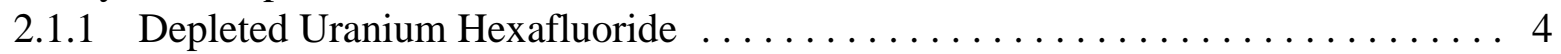

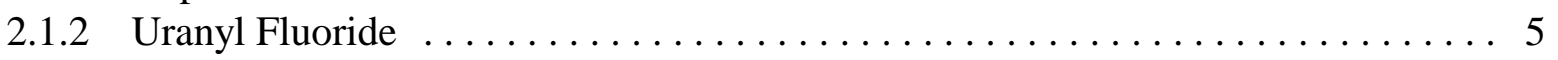

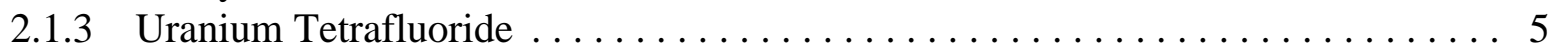

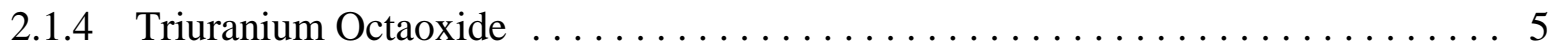

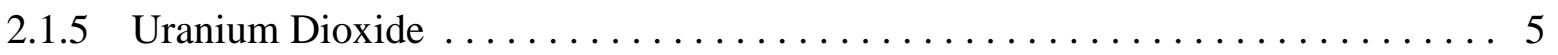

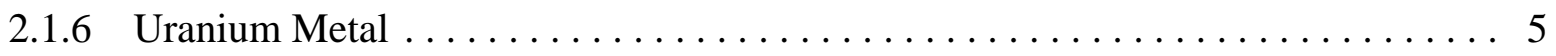

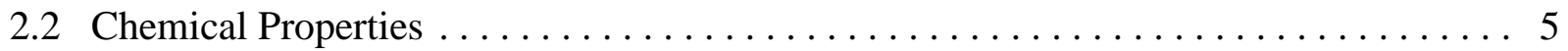

2.2 .1 Depleted Uranium Hexafluoride $\ldots \ldots \ldots \ldots \ldots \ldots \ldots \ldots \ldots \ldots \ldots \ldots \ldots \ldots \ldots \ldots \ldots \ldots$

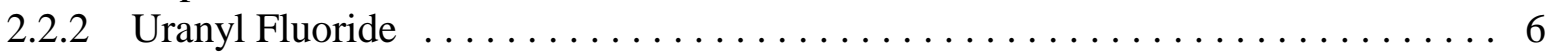

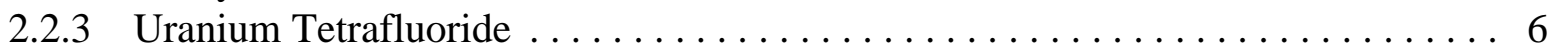

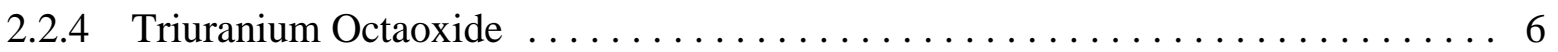

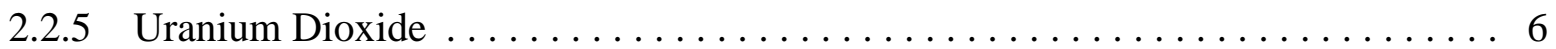



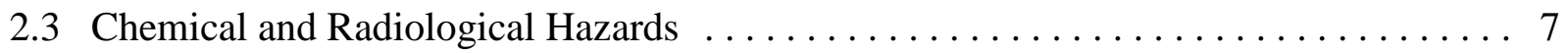

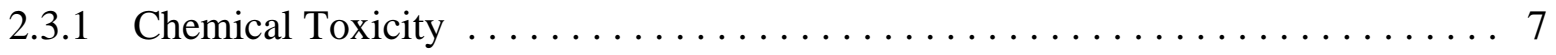

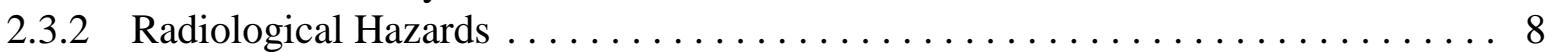

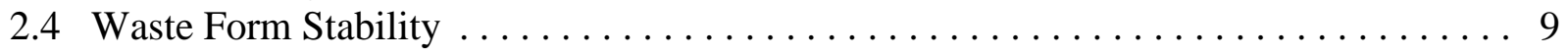

2.5 Potential Waste Forms . . . . . . . . . . . . . . . . . . . . . . . . . . . . 9

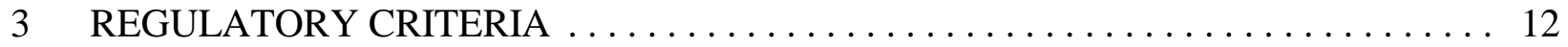

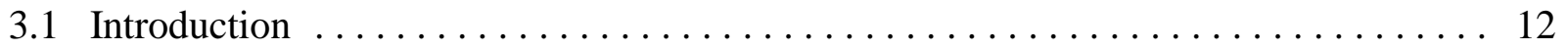

3.2 Environmental Laws and Regulations Governing Solid and Hazardous

Waste Management .................................... 13

3.3 Environmental Laws and Regulations Governing Radioactive Materials Management 13

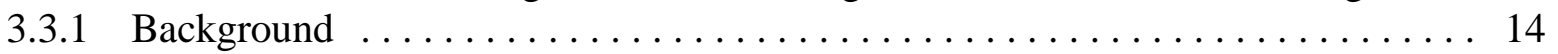

3.3.2 Requirements for Disposal of Low-Level Wastes at Non-DOE Facilities . . . . 16

3.3.3 Requirements for Disposal of Low-Level Wastes at DOE Facilities . . . . . . . . . 19

3.3.4 Clean Air Act (CAA) . . . . . . . . . . . . . . . . . . . . . . . . . . 21

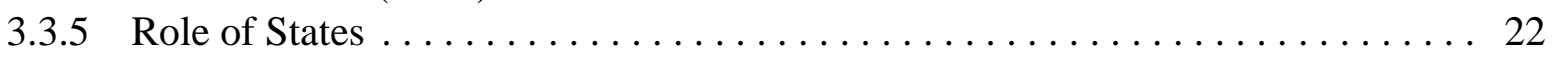

3.4 Environmental Laws and Regulations Governing Federal Agency Decisions . . . . . 22

3.4.1 National Environmental Policy Act (NEPA) . . . . . . . . . . . . . . . . 22

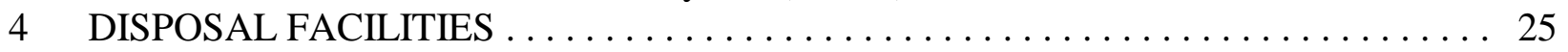

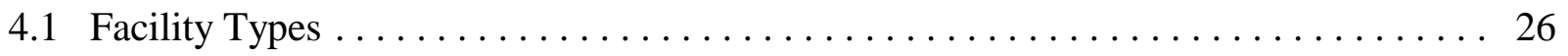

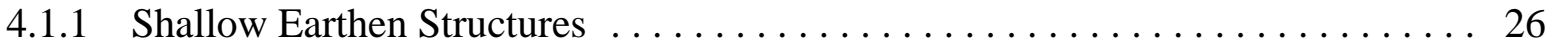

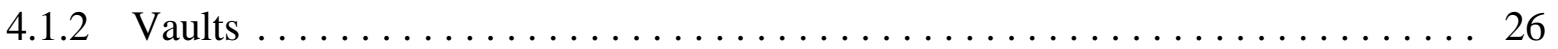




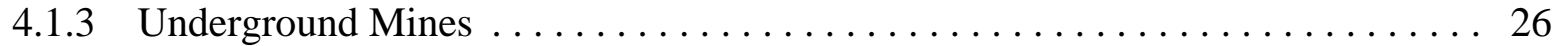

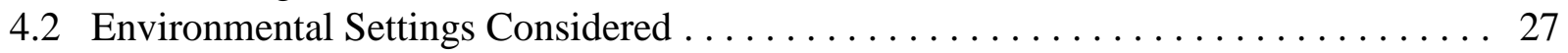

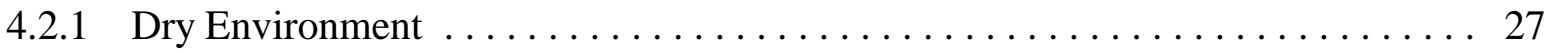

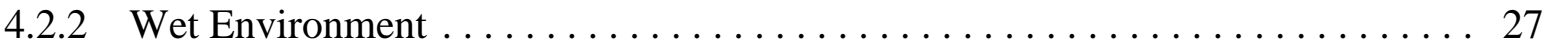

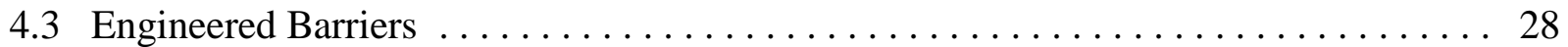

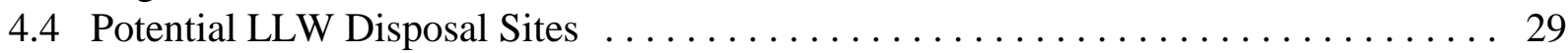

4.4 .1 Hanford Site . . . . . . . . . . . . . . . . . . . . . . . . . . 29

4.4 .2 Nevada Test Site . . . . . . . . . . . . . . . . . . . . . . . . . . . 29

4.4 .3 Barnwell . . . . . . . . . . . . . . . . . . . . . . . . . . . . 30

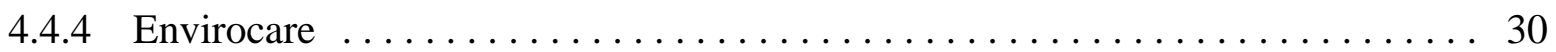

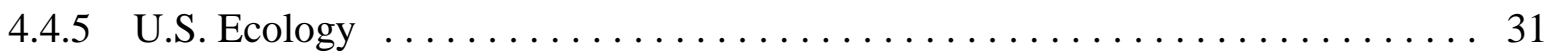

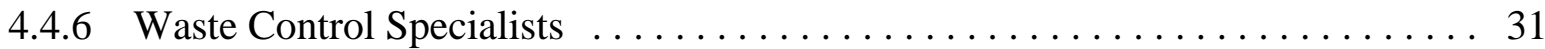

4.4 .7 Waste Acceptance Criteria . . . . . . . . . . . . . . . . . . . 31

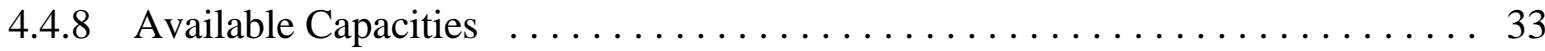

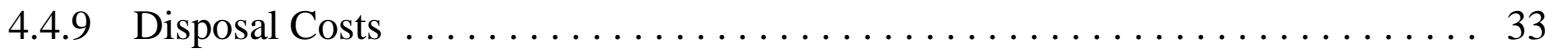



5.1 Construction Impacts for Vault or Underground Mine Disposal . . . . . . . . . . 36

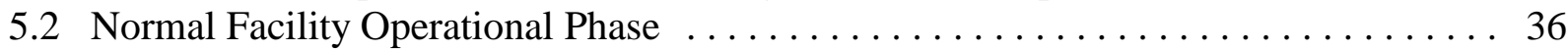

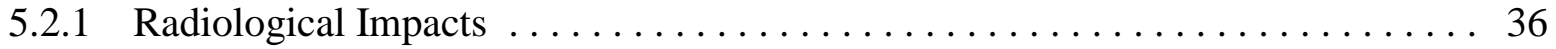

5.2 .2 Chemical Impacts . . . . . . . . . . . . . . . . . . . . . . 37

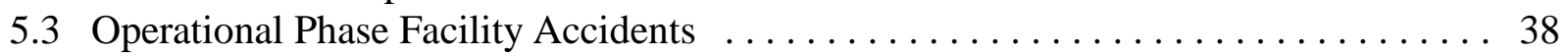

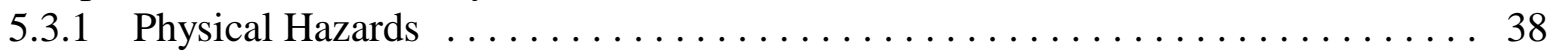

5.3 .2 Accidental Release of Depleted Uranium $\ldots \ldots \ldots \ldots \ldots \ldots \ldots \ldots \ldots \ldots$

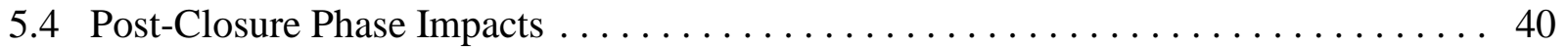

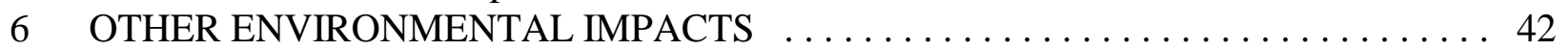

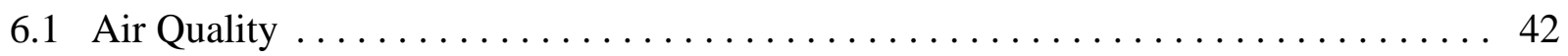

6.1.1 Construction Impacts for Vault or Underground Mine Disposal . . . . . . . . . . 42

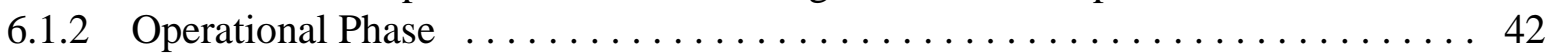

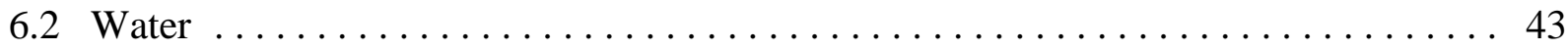

6.2.1 Construction Impacts for Vault or Underground Mine Disposal . . . . . . . . 43

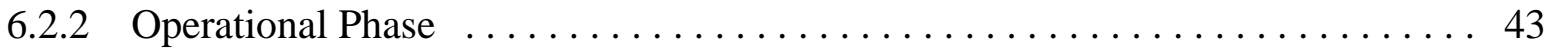

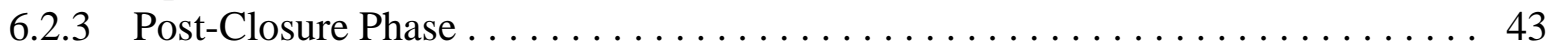

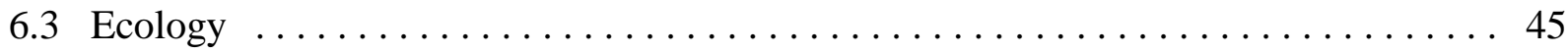

6.3.1 Construction Impacts for Vault or Underground Mine Disposal . . . . . . . . . 45

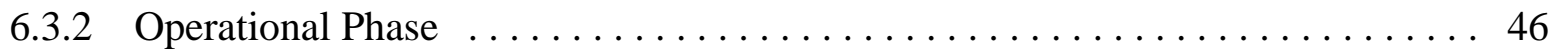

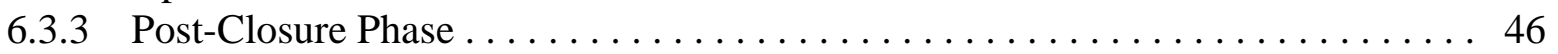

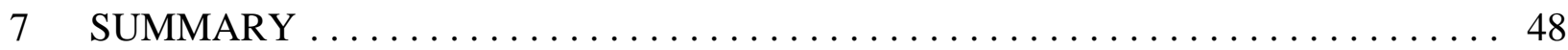

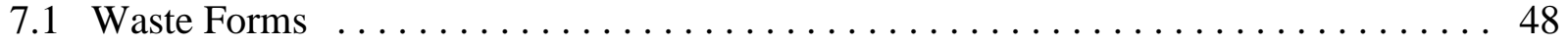

7.2 Applicable Regulations $\ldots \ldots \ldots \ldots \ldots \ldots \ldots \ldots \ldots \ldots \ldots \ldots \ldots \ldots \ldots \ldots$

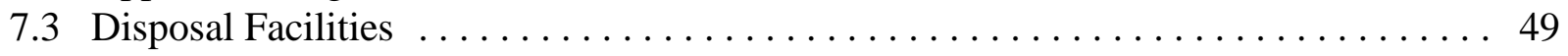

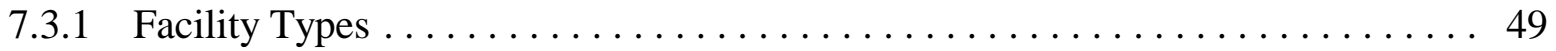

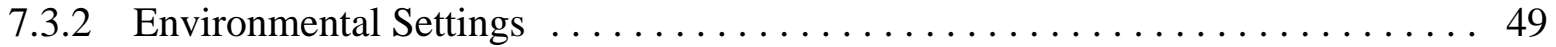

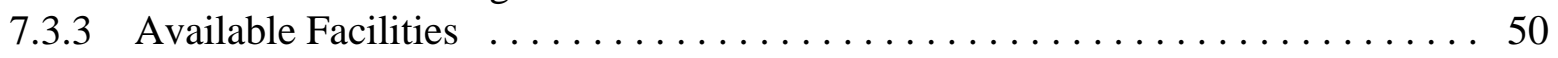

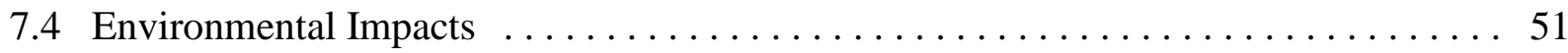

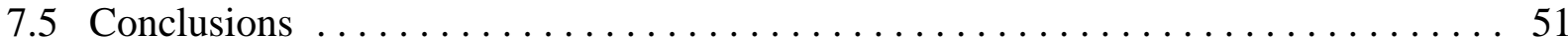

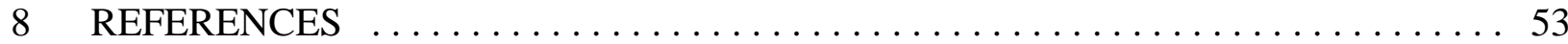




\section{APPENDIX A}

Analysis of Whether Depleted Uranium in Oxide or Metal Form Would Be Source Material, Byproduct Material or Special Nuclear Material . . . . . . . . . . . . . . . A-1

A.1 Description of DOE's Depleted Uranium Inventory $\ldots \ldots \ldots \ldots \ldots \ldots \ldots \ldots \ldots$ A-1

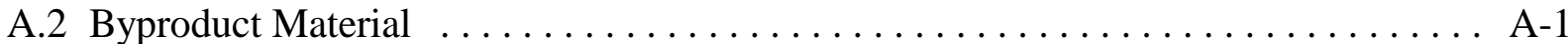

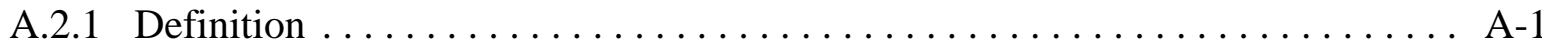

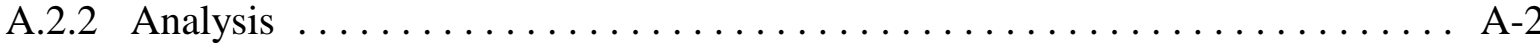

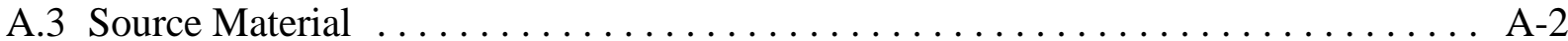

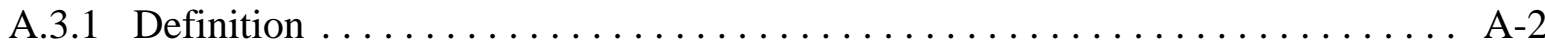

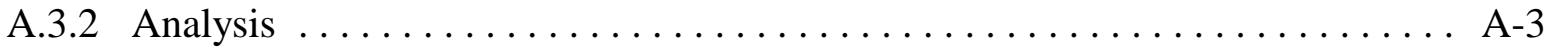

A.4 Special Nuclear Material $(\mathrm{SNM}) \ldots \ldots \ldots \ldots \ldots \ldots \ldots \ldots \ldots \ldots \ldots \ldots \ldots \ldots$

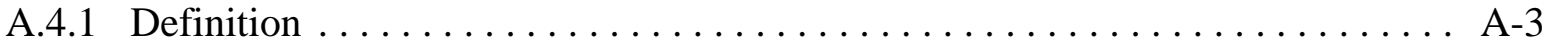

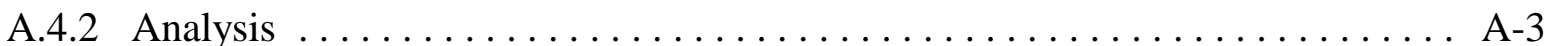

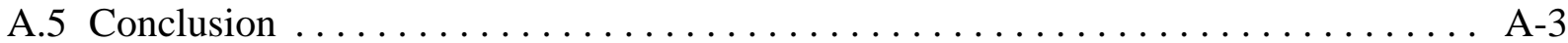

\section{APPENDIX B}

Analysis of Whether Discarded Depleted Uranium in Oxide or Metal Form Would Be High-Level Waste, Spent Nuclear Fuel, Transuranic Waste, or Low-Level Waste . . . . . . . . . . . . B-1

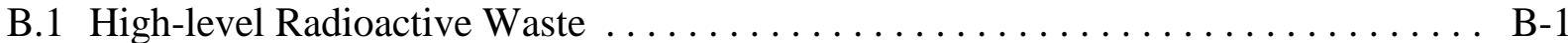

B.1.1 Definition ...............................

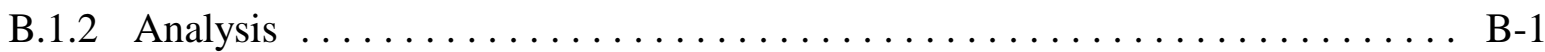

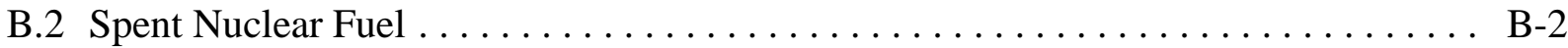

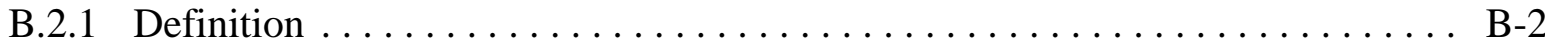

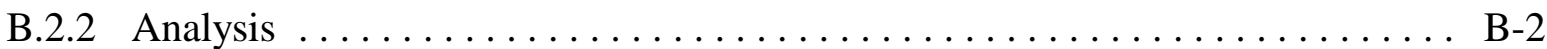

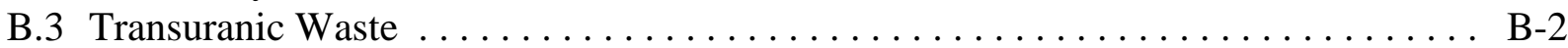

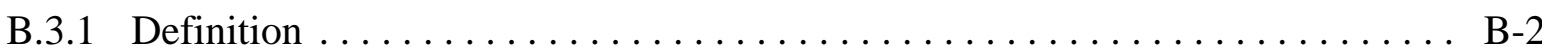

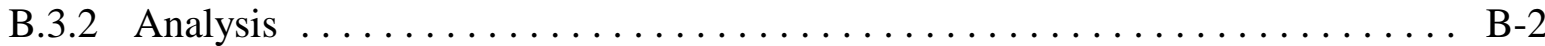

B.4 Low-level Radioactive Waste $\ldots \ldots \ldots \ldots \ldots \ldots \ldots \ldots \ldots \ldots \ldots \ldots \ldots \ldots$. . . . . . . . . . . . . . .



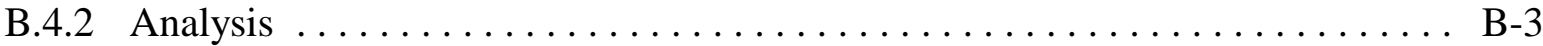

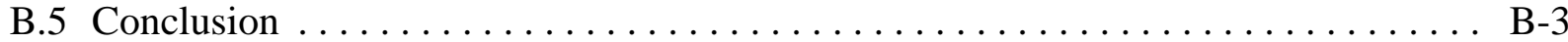

\section{APPENDIX C}

Waste Acceptance Criteria . . . . . . . . . . . . . . . . . . . . . . . C-1

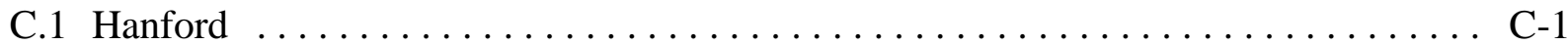

C.2 Nevada Test Site $\ldots \ldots \ldots \ldots \ldots \ldots \ldots \ldots \ldots \ldots \ldots \ldots \ldots \ldots \ldots$ C -7

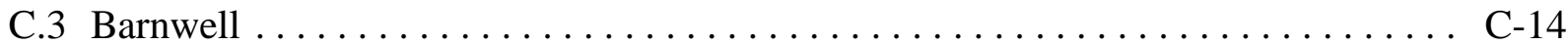

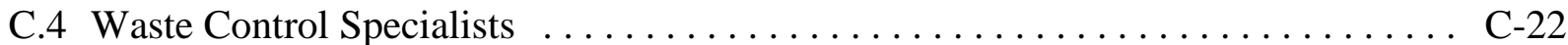

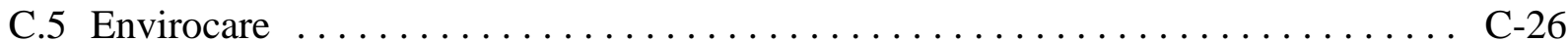

\section{APPENDIX D}

DOE Agreements with Ohio and Tennessee $\ldots \ldots \ldots \ldots \ldots \ldots \ldots \ldots \ldots \ldots \ldots \ldots \ldots \ldots$

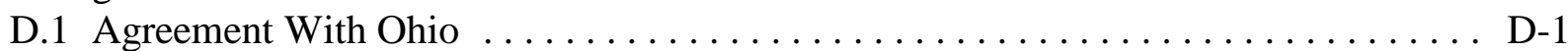

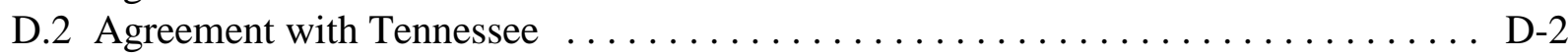

D.3 Disposal of Depleted Uranium in Ohio if Depleted $\mathrm{UF}_{6}$ is Hazardous Waste . . . . . D-2 


\section{TABLES}

Table 1.1 Inventory of Standard 48-Inch DUF Cylinders $\ldots \ldots \ldots \ldots \ldots \ldots \ldots \ldots_{\ldots} \ldots \ldots \ldots$

Table 2.1 Physical Properties of Pertinent Uranium Compounds . . . . . . . . . . . . . 57

Table 3.1 Definitions of Radioactive Waste Categories . . . . . . . . . . . . . . . . . . 59

Table 3.2 Low-Level Waste Land Disposal Facility Performance Objectives . . . . . . . . . 60

Table 3.3 Summary of Technical Requirements for Near-Surface Land Disposal Facilities . . 61

Table 3.4 Waste Characteristics and Stability Requirements . . . . . . . . . . . . 62

Table 3.5 DOE Orders and Regulations Applicable to Low-Level Waste Disposal . . . . . . . 63

Table 3.6 Components of the Radioactive Waste Management Basis for DOE Low-Level Waste Disposal Facilities . . . . . . . . . . . . . . . . . . . . . 64

Table 3.7 Minimum Topics To Be Covered In Waste Acceptance Criteria For DOE Low-Level

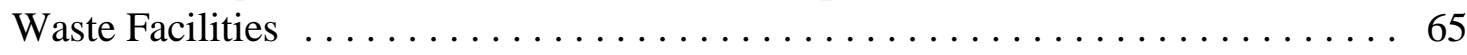

Table 3.8 Minimum Design Requirements for DOE Low-Level Waste Disposal Facilities . . 65

Table 3.9 Performance Objectives for DOE-Regulated Low-Level Waste Disposal Facilities . 66

Table 4.1 Disposal Site Capacity and Costs for the Depleted Uranium Waste Form Options . 67

Table 5.1 Annual Average Radiological Impacts to Involved Workers from Disposal Options for Normal Operations . . . . . . . . . . . . . . . . . . . 68

Table 5.2 Potential Impacts to Human Health from Physical Hazards under Accident Conditions for the Disposal Options . . . . . . . . . . . . . . . . . . . . . . . . 69

Table 5.3 Accidents Considered for the Disposal Options $\ldots \ldots \ldots \ldots \ldots \ldots \ldots \ldots \ldots$

Table 5.4 Estimated Radiological Doses per Accident Occurrence for the Disposal Options . 71

Table 5.5 Estimated Radiological Health Risks per Accident Occurrence for the Disposal

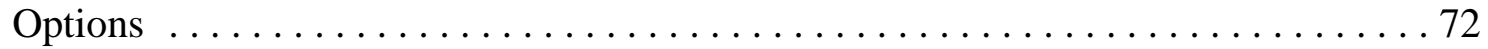

Table 5.6 Number of Persons with Potential for Adverse Effects from Accidents under the

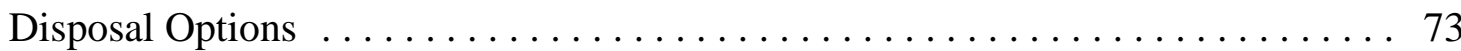

Table 5.7 Human Health Impacts for the MEI from Disposal Options: Post-Closure Phase . . 74

Table 6.1 Maximum Annual Average Uranium Concentrations in Air during Operation of the Wasteform Facility for Disposal of Grouted Uranium Oxide . . . . . . . . 75

Table 6.2 Summary of Water Parameters for the Disposal Facility During the Operational

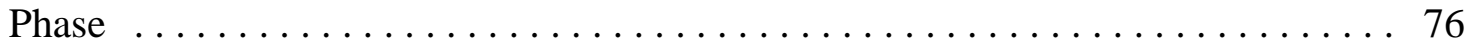

Table 6.3 Potential Radiological and Chemical Impacts to Aquatic Biota due to Failure of a






\section{INTRODUCTION}

The U.S. Department of Energy (DOE) is analyzing strategies for the long-term manage-ment of the depleted uranium hexafluoride $\left(\mathrm{UF}_{6}\right)$ inventory currently stored at three DOE sites near Paducah, Kentucky; Portsmouth, Ohio; and Oak Ridge, Tennessee. One option under consideration is the conversion of the depleted $\mathrm{UF}_{6}$ inventory to a more stable chemical form for permanent disposal (DOE 1999). This letter report further investigates potential waste forms, potential disposal sites, and the estimated environmental impacts during the operational and post-closure phases of a central disposal facility.

\subsection{Background}

Depleted $\mathrm{UF}_{6}$ results from the process of making uranium suitable for use as fuel for nuclear reactors or military applications. The use of uranium in these applications requires increasing the proportion of the uranium-235 isotope found in natural uranium, which is approximately $0.7 \%$, through an isotopic separation process called uranium enrichment. An enrichment process called gaseous diffusion is currently used in the United States. The depleted UF 6 by-product has a uranium235 proportion of approximately $0.25 \%$ of the total uranium.

Large-scale uranium enrichment in the United States began as part of atomic bomb development by the Manhattan Project during World War II. Uranium enrichment activities were subsequently continued under the U.S. Atomic Energy Commission and its successor agencies, including DOE. The K-25 plant in Oak Ridge, Tennessee was the first of three gaseous diffusion plants constructed to produce enriched uranium. The K-25 plant ceased operations in 1985, but uranium enrichment continues at the other two sites located in Paducah, Kentucky and Portsmouth, Ohio. These two plants are now operated by the United States Enrichment Corporation (USEC), created by law in 1993 to privatize the uranium enrichment program.

Since the 1950s, depleted $\mathrm{UF}_{6}$ has been stored at all three storage sites in large steel cylinders. Several different cylinder types are in use, although the vast majority of cylinders have a 14-ton (12metric-ton) capacity. The cylinders are typically $12 \mathrm{ft}(3.7 \mathrm{~m})$ long by $4 \mathrm{ft}(1.2 \mathrm{~m})$ in diameter, with most having a wall thickness of $5 / 16$ in. $(0.79 \mathrm{~cm})$ of steel. Similar, but slightly smaller, cylinders with a capacity of 10 tons ( 9 metric tons) are also in use. During storage, a cylinder contains solid $\mathrm{UF}_{6}$ in the bottom and $\mathrm{UF}_{6}$ gas at less than atmospheric pressure in the top. The depleted $\mathrm{UF}_{6}$ cylinders managed by DOE at the three sites are typically stacked two layers high in large areas called yards. Table 1.1 lists the depleted $\mathrm{UF}_{6}$ inventories at each site.

The characteristics of $\mathrm{UF}_{6}$ pose potential health risks, and the material is handled accordingly. Uranium is radioactive, and $\mathrm{UF}_{6}$ in storage emits low levels of gamma and neutron radiation. The radiation levels measured on the outside surface of filled depleted $\mathrm{UF}_{6}$ storage cylinders are typically about 2 to 3 millirem per hour ( $\mathrm{mrem} / \mathrm{h})$, decreasing to about $1 \mathrm{mrem} / \mathrm{h}$ at a distance of $1 \mathrm{ft}(0.3 \mathrm{~m})$. In addition, if $\mathrm{UF}_{6}$ is released to the atmosphere, it reacts with water vapor in the air, forming hydrogen fluoride (HF) and a uranium-fluoride compound called uranyl fluoride $\left(\mathrm{UO}_{2} \mathrm{~F}_{2}\right)$. These products are chemically toxic. Uranium is a heavy metal that, in addition to being radioactive, can 
have toxic chemical effects (primarily on the kidneys) if it enters the bloodstream by means of ingestion or inhalation. HF is an extremely corrosive gas that can damage the lungs and cause death if inhaled at high enough concentrations.

Cylinders are stored with minimum risks to workers, members of the general public, and the environment at the Paducah, Portsmouth, and K-25 sites. DOE maintains an active cylinder management program to improve storage conditions in the cylinder yards, to monitor cylinder integrity by conducting routine inspections for breaches, and to perform cylinder maintenance and repairs as needed.

Because storage began in the early 1950s, many of the cylinders now show evidence of external corrosion. Before 1998, seven cylinders (one at Paducah, two at Portsmouth, and four at K25) had been identified that had developed holes (breaches), generally around spots previously damaged by handling activities. In 1998, one additional cylinder breach occurred during the course of cylinder maintenance operations. Because the depleted $\mathrm{UF}_{6}$ is a solid at ambient temperatures and pressures, it is not readily released from a cylinder following a leak or breach. When a cylinder is breached, moist air reacts with the exposed $\mathrm{UF}_{6}$ solid and iron, resulting in the formation of a dense plug of solid uranium and iron compounds and a small amount of HF gas. This plug limits the amount of material released from a breached cylinder. When a cylinder breach is identified, the cylinder is repaired or its contents are transferred to a new cylinder.

Several alternatives are currently under consideration by DOE for the long-term management of this depleted uranium inventory (DOE 1999). One such alternative is the conversion of the depleted $\mathrm{UF}_{6}$ to a more stable form such as triuranium octaoxide $\left(\mathrm{U}_{3} \mathrm{O}_{8}\right)$, uranium dioxide $\left(\mathrm{UO}_{2}\right)$, or uranium metal for long-term storage, permanent disposal, or a combination of the two.

\subsection{Scope}

This report summarizes information currently available concerning potential disposal options for depleted uranium (DU). The feasibility of disposing the DU contained in the approximately $700,000 \mathrm{MT}$ of depleted $\mathrm{UF}_{6}$ that the DOE is currently responsible for managing is assessed. The assessment considers the disposal of $\mathrm{DU}$ in various physical and chemical forms (e.g., as $\mathrm{U}_{3} \mathrm{O}_{8}, \mathrm{UO}_{2}$, and metal, including grouted oxide forms) in different facilities (e.g., shallow earthen structures, vaults, and underground mines) and two different environmental settings (a dry and a wet environment). Potential disposal sites (both DOE owned and commercial) have been contacted and information has been gathered about their disposal practices and costs. Although the disposal of depleted uranium metal was not analyzed in detail in the PEIS (DOE 1999) because of stability concerns, a qualitative assessment of impacts for disposal of DU as metal is given in each of the following sections when possible because of recent inquiries into the matter.

In the evaluation, the following factors are considered: technical feasibility, stability of the waste form, the role of the engineered barriers, human health and safety, environmental impacts, regulatory constraints, availability of disposal capacity, and cost. The reported impacts are for the operational and post-closure phases of a disposal facility under normal operational conditions and potential accident conditions during operations. Included are impacts associated with grouting operations for enhanced stability, if applicable, for the waste form under consideration. 


\section{DEPLETED URANIUM PROPERTIES AND POTENTIAL WASTE FORMS}

Selection of a suitable wasteform for the disposition of DU is dependent upon the physical and chemical properties of applicable uranium compounds. The uranium compounds under consideration are those that are either intermediate compounds or end-products of commercially available processes. Conversion of $\mathrm{UF}_{6}$ into uranium-bearing minerals such as soddyite and uranotile for subsequent disposal were not analyzed because development of chemical conversion processes would be required, as well as examination of the suitability of such forms for disposal.

\subsection{Physical Properties}

The physical properties of the pertinent chemical forms of uranium are shown in Table 2.1.

\subsubsection{Depleted Uranium Hexafluoride}

$\mathrm{UF}_{6}$ at ambient conditions is a volatile, white, crystalline solid. Solid $\mathrm{UF}_{6}$ is readily transformed into the gaseous or liquid states by the application of heat. All three phases - solid, liquid, and gas - coexist at $147^{\circ} \mathrm{F}\left(64^{\circ} \mathrm{C}\right)$ (the triple point). Only the gaseous phase exists above $446^{\circ} \mathrm{F}\left(230^{\circ} \mathrm{C}\right)$, the critical temperature, at which the critical pressure is $45.5 \mathrm{~atm}(4.61 \mathrm{mPa})$. The vapor pressure above the solid reaches 1 atm $(0.1 \mathrm{mPa})$ at $133^{\circ} \mathrm{F}\left(56^{\circ} \mathrm{C}\right)$, the sublimation temperature.

Figure 2.1 is the phase diagram covering the range of conditions usually encountered in working with $\mathrm{UF}_{6}$. It shows the correlation of pressure and temperature with the physical state of $\mathrm{UF}_{6}$. The triple point occurs at 22 pounds per square inch, absolute (psia) and $147^{\circ} \mathrm{F}\left(64^{\circ} \mathrm{C}\right)$. These are the only conditions at which all three states - liquid, solid, and gas - can exist in equilibrium. If the temperature or pressure is greater than at the triple point, there will only be gas or liquid.

A large decrease in $\mathrm{UF}_{6}$ density occurs when $\mathrm{UF}_{6}$ changes from the solid to the liquid state, which results in a large increase in volume. The thermal expansion of the liquid with increasing temperature is also high. Therefore, it is important to maintain control of the total mass and physical state of $\mathrm{UF}_{6}$ throughout an operational cycle. To avoid hydraulic rupture, when items with restricted volumes, such as traps and containers, are filled with $\mathrm{UF}_{6}$, full allowance must be made for the volume changes that will arise over the working temperature range to which the vessels will be subjected.

For $\mathrm{UF}_{6}$ to be handled as a liquid, the pressure must be in excess of $0.15 \mathrm{mPa}(1.5 \mathrm{~atm})$ and the temperature above $147^{\circ} \mathrm{F}\left(64^{\circ} \mathrm{C}\right)$ because the sublimation temperature lies below the triple point. Thus, any process using liquid $\mathrm{UF}_{6}$ is above atmospheric pressure and is subject to a potential leakage of $\mathrm{UF}_{6}$ to the environment, with vapor loss and cooling occurring simultaneously. Solidification occurs exothermically when the pressure falls below $1.5 \mathrm{~atm}(0.15 \mathrm{mPa})$. Thus, if a cylinder heated above the triple point is breached, a rapid outflow of the $\mathrm{UF}_{6}$ occurs until the pressure drops sufficiently to start the solidification process. The rate of outflow then decreases but continues until the contents cool to about $133^{\circ} \mathrm{F}\left(56^{\circ} \mathrm{C}\right)$, which is the atmospheric sublimation 
temperature. Some release of material may continue, depending on the type and location of the breach.

$\mathrm{UF}_{6}$ is hygroscopic (i.e., moisture-retaining) and, in contact with water $\left(\mathrm{H}_{2} \mathrm{O}\right)$, will decompose immediately to uranyl fluoride $\left(\mathrm{UO}_{2} \mathrm{~F}_{2}\right)$. When heated to decomposition, $\mathrm{UF}_{6}$ emits toxic fluoride fumes.

\subsubsection{Uranyl Fluoride}

Uranyl fluoride $\left(\mathrm{UO}_{2} \mathrm{~F}_{2}\right)$ is a pale yellow crystalline solid that is highly soluble in water and decomposes at $300^{\circ} \mathrm{C}$ to form $\mathrm{U}_{3} \mathrm{O}_{8}$ and some $\mathrm{UF}_{4}$ (Katz and Rabinowitch 1951). It is a reaction product of $\mathrm{UF}_{6}$ and water.

\subsubsection{Uranium Tetrafluoride}

Uranium tetrafluoride $\left(\mathrm{UF}_{4}\right)$ is a green crystalline solid that melts at about $1,760^{\circ} \mathrm{F}\left(960^{\circ} \mathrm{C}\right)$ and has an insignificant vapor pressure. It is very slightly soluble in water. It is generally an intermediate in the conversion of $\mathrm{UF}_{6}$ to either uranium oxide $\left(\mathrm{U}_{3} \mathrm{O}_{8}\right.$ or $\left.\mathrm{UO}_{2}\right)$ or uranium metal.

\subsubsection{Triuranium Octaoxide}

Triuranium octaoxide $\left(\mathrm{U}_{3} \mathrm{O}_{8}\right)$ occurs naturally as the olive-green-colored mineral pitchblende. It is insoluble in water and decomposes to $\mathrm{UO}_{2}$ and $\mathrm{UO}_{3}$ when heated to a temperature of about $1,300^{\circ} \mathrm{C}$.

\subsubsection{Uranium Dioxide}

Uranium dioxide $\left(\mathrm{UO}_{2}\right)$ is the form in which uranium is most commonly used as a nuclear reactor fuel. It is a stable ceramic that can be heated almost to its melting point, $5,212^{\circ} \mathrm{F}\left(2,878^{\circ} \mathrm{C}\right)$, without serious mechanical deterioration. It does not react with water to any significant level. At ambient temperatures, $\mathrm{UO}_{2}$ will gradually convert to $\mathrm{U}_{3} \mathrm{O}_{8}$ in the presence of oxygen.

\subsubsection{Uranium Metal}

Uranium metal appears as a heavy, silvery white, malleable, ductile, softer-than-steel, metallic element. It is one of the densest materials known $\left(19 \mathrm{~g} / \mathrm{cm}^{3}\right)$, being 1.6 times more dense than lead. Uranium metal has a melting point of $1,132^{\circ} \mathrm{C}$.

\subsection{Chemical Properties}

A wide range of uranium compounds is possible because of the multiple valence states available to uranium $(+3,+4,+5$, or +6$)$. The chemical properties of uranium are independent of the isotope involved. Thus, the following properties are valid for all uranium enrichments.

\subsubsection{Depleted Uranium Hexafluoride}

Uranium hexafluoride $\left(\mathrm{UF}_{6}\right)$ combines with water to form the soluble reaction products $\mathrm{UO}_{2} \mathrm{~F}_{2}$ and (hydrogen fluoride) $\mathrm{HF}$. $\mathrm{UF}_{6}$ is essentially inert to clean aluminum, steel, Monel, nickel, aluminum, bronze, copper, and Teflon ${ }^{\mathrm{TM}}$. Teflon is commonly used in the packing and cap gasket for cylinders storing depleted $\mathrm{UF}_{6}$. When released to the atmosphere, gaseous $\mathrm{UF}_{6}$ combines with 
humidity to form a cloud of particulate $\mathrm{UO}_{2} \mathrm{~F}_{2}$ and $\mathrm{HF}$ fumes. The reaction is very fast and is dependent on the availability of water vapor. Following a large-scale release of $U_{6}$ in an open area, the dispersion is governed by meteorological conditions, and the plume could still contain unhydrolyzed material even after traveling a distance of several hundred meters. After hydrolysis, $\mathrm{UO}_{2} \mathrm{~F}_{2}$ can be deposited as a finely divided solid, while $\mathrm{HF}$ remains as part of the gas plume.

In enclosed situations, the reaction products form a dense fog, reducing visibility for occupants of the area and hindering evacuation and emergency response. Fog can occur in unconfined areas if the humidity is high.

In a fire, the reaction of $\mathrm{UF}_{6}$ with water is accelerated because of the increased $\mathrm{UF}_{6}$ vapor pressure and the large quantities of water formed in combustion of organic materials or hydrocarbons. Reaction of liquid $\mathrm{UF}_{6}$ with hydrocarbon vapors is extremely vigorous in flames, with formation of $\mathrm{UF}_{4}$ and low-molecular-weight fluorinated compounds. More heat is generally released in these hydrocarbon interactions with $\mathrm{UF}_{6}$ than in the corresponding reactions of hydrocarbons with oxygen.

\subsubsection{Uranyl Fluoride}

$\mathrm{UO}_{2} \mathrm{~F}_{2}$ can be formed through the reaction of $\mathrm{UF}_{6}$ with water or the reaction of uranium trioxide with $\mathrm{HF}$ at elevated temperatures. The reverse reaction, formation of $\mathrm{UF}_{6}$ from $\mathrm{UO}_{2} \mathrm{~F}_{2}$, can be accomplished in the presence of $\mathrm{F}_{2}$. Uranyl fluoride undergoes reduction with $\mathrm{H}_{2}$ at temperatures above $500^{\circ} \mathrm{C}$ to form $\mathrm{UO}_{2}$ and $\mathrm{HF}$.

\subsubsection{Uranium Tetrafluoride}

Uranium tetrafluoride $\left(\mathrm{UF}_{4}\right)$ can be prepared by the high temperature reaction of $\mathrm{UO}_{2}$ with $\mathrm{HF}$ or by the electrolytic reduction of $\mathrm{UO}_{2} \mathrm{~F}_{2}$ in aqueous $\mathrm{HF}$. It can also be formed by the reaction of $\mathrm{UF}_{6}$ with hydrogen gas in a vertical tube-type reactor. $\mathrm{UF}_{4}$ can be readily converted to either uranium metal or uranium oxide. $\mathrm{UF}_{4}$ can be converted to $\mathrm{UF}_{6}$ through either fluorination with $\mathrm{F}_{2}$ or oxidation with $\mathrm{O}_{2}$. $\mathrm{UF}_{4}$ reacts slowly with moisture at ambient temperature, forming $\mathrm{UO}_{2}$ and $\mathrm{HF}$.

\subsubsection{Triuranium Octaoxide}

$\mathrm{U}_{3} \mathrm{O}_{8}$ is readily produced from $\mathrm{UF}_{6}$ and has potential long-term stability in a geologic environment. In the presence of oxygen $\left(\mathrm{O}_{2}\right)$, uranium dioxide $\left(\mathrm{UO}_{2}\right)$ and uranium trioxide $\left(\mathrm{UO}_{3}\right)$ are oxidized to $\mathrm{U}_{3} \mathrm{O}_{8}$. $\mathrm{U}_{3} \mathrm{O}_{8}$ can be made by three primary chemical conversion processes, involving either $\mathrm{UF}_{4}$ or $\mathrm{UO}_{2} \mathrm{~F}_{2}$ as intermediates. It is generally considered to be the more attractive form for disposal purposes because, under normal environmental conditions, $\mathrm{U}_{3} \mathrm{O}_{8}$ is one of the most kinetically and thermodynamically stable forms of uranium and also because it is a form of uranium often found in nature. Triuranium octaoxide $\left(\mathrm{U}_{3} \mathrm{O}_{8}\right)$ has no hazardous chemical properties that are significant.

\subsubsection{Uranium Dioxide}

In addition to being a primary component in nuclear reactor fuel, uranium dioxide is often the starting material for production of $\mathrm{UF}_{6}$ with $\mathrm{UF}_{4}$ as an intermediate. $\mathrm{UO}_{2}$ will slowly convert to $\mathrm{U}_{3} \mathrm{O}_{8}$ in air at ambient temperature. Its stability in air can be improved by sintering the powder in hydrogen 


\subsubsection{Uranium Metal}

Uranium metal is not as stable as $\mathrm{U}_{3} \mathrm{O}_{8}$ or $\mathrm{UF}_{4}$ because it is subject to surface oxidation. It tarnishes in air, with the oxide film slowing further oxidation of massive metal at room temperature. Uranium powder or chips will ignite spontaneously in air at ambient temperature due to rapid oxidation of the metal.

Solid uranium, either as chips or dust, is a very dangerous fire hazard when exposed to heat or flame. In addition, uranium metal can react violently with chlorine $\left(\mathrm{Cl}_{2}\right)$, fluorine $\left(\mathrm{F}_{2}\right)$, nitric acid $\left(\mathrm{HNO}_{3}\right)$, selenium $(\mathrm{Se})$, sulfur $(\mathrm{S})$, ammonia $\left(\mathrm{NH}_{3}\right)$, bromine fluoride $\left(\mathrm{BrF}_{3}\right)$, trichlorethylene $(\mathrm{TCE})$, or nitryl fluoride and similar compounds.

Water reacts with bulk uranium metal slowly at room temperature and rapidly at higher temperatures causing the metal to swell and disintegrate. $\mathrm{UO}_{2}$ and hydrogen gas are formed. If the hydrogen gas is not permitted to escape, such as in a closed container, uranium hydride $\left(\mathrm{UH}_{3}\right)$ is also formed (Solbrig et al. 1994). The hydride will ignite spontaneously in the presence of oxygen. Thus, uranium ingots can form a pyrophoric surface in an oxygen depleted atmosphere during storage because of reaction with moisture.

\subsection{Chemical and Radiological Hazards}

The radioactive nature and chemical toxicity of uranium can both present exposure hazards to human health. The chemical toxicity of natural and depleted uranium has been the primary concern when establishing occupational and environmental limits. The radiological hazards of depleted uranium are generally less important than its chemical hazards.

\subsubsection{Chemical Toxicity}

The chemical toxicity of uranium is comparable to other metals such as arsenic and lead. The main chemical effect associated with exposure to uranium and its compounds is kidney toxicity. This toxicity occurs when soluble uranium compounds enter the bloodstream (either through inhalation or ingestion), are filtered by the kidneys, and the uranium ions cause damage to the kidney cells. The damage is detected by the presence of protein and dead cells in the urine; there are no other clinical symptoms unless the exposure level was very high (that is, the total uranium intake was greater than about $40 \mathrm{mg}$ ). It is reported that unless the exposure levels are quite high, when the uranium exposure has stopped, the kidney repairs itself over a period of several weeks until no damage would be detected by microscopic examination (McGuire 1991).

Chronic low-level exposure to depleted uranium compounds could occur for persons working in depleted uranium disposal facilities. Exposure to the more soluble uranium compounds such as $\mathrm{UF}_{6}, \mathrm{UF}_{4}$, and $\mathrm{UO}_{2} \mathrm{~F}_{2}$ would present the largest chemical hazard since they can easily enter the bloodstream when inhaled or ingested. The current time weighted average permissible exposure levels (PEL-TWA) for uranium air contaminants are 0.05 and $0.25 \mathrm{mg} / \mathrm{m}^{3}$ for soluble and insoluble uranium compounds, respectively, as set forth by the Occupational Safety and Health Administration (29 CFR Part 1910). These levels are similar to the Threshold Limit Values (TLVs) for uranium of 
$0.2 \mathrm{mg} / \mathrm{m}^{3}$ (for both soluble and insoluble uranium compounds) as recommended by the American Conference of Governmental Industrial Hygienists (ACGIH) (29 CFR Part 1926). A maximum concentration level (MCL) of $20 \mathrm{~g} / \mathrm{L}(30 \mathrm{pCi} / \mathrm{L})$ for uranium in drinking water has been proposed by the EPA (56 FR 33050).

\subsubsection{Radiological Hazards}

Several possible health effects are associated with human exposure to radiation. The health effects from radiation exposure depend on the level of exposure, the type of radiation (alpha, beta, or gamma radiation), the duration of the exposure, and whether the exposure was from radioactive material outside the body (external exposure) or from radioactive material ingested or inhaled (internal exposure). At the exposure levels typically associated with the handling and processing of uranium, the primary health effect of concern is an increased probability of the exposed individual developing cancer during their lifetime. Cancer cases induced by radiation are generally indistinguishable from other "naturally occurring" cancers and may occur years after the exposure takes place.

All isotopes of uranium are radioactive and decay into other radionuclides (decay products). Uranium and its decay products primarily emit alpha radiation, however, lower levels of both beta and gamma radiation are also emitted. The total activity level of uranium depends on the isotopic composition and processing history. An average isotopic composition of depleted uranium is approximately $99.75 \%$ uranium-238, $0.25 \%$ uranium-235, and $0.001 \%$ uranium-234 (LLNL 1997a), as well as a number of radioactive decay products. The corresponding specific activity (alpha) is $4 \times 10^{-7} \mathrm{Ci} / \mathrm{g}$ of depleted uranium. The most important decay products are Th- 234 and $\mathrm{Pa}-234 \mathrm{~m}$ from U-238 that are considered to be in secular equilibrium with U-238 after several months. In general, uranium-235 and uranium-234 pose a greater radiological health risk than uranium-238 because they have much shorter half-lives and thus decay more quickly. Because all uranium isotopes are primarily alpha emitters, their primary hazard is from ingestion or inhalation.

However, a slight hazard is posed by external radiation. Depleted $\mathrm{UF}_{6}$ in storage emits low levels of gamma and neutron radiation as mentioned in Section 1.1. The radiation levels measured on the outside surface of filled depleted $\mathrm{UF}_{6}$ storage cylinders are typically about 2 to 3 millirem per hour $(\mathrm{mrem} / \mathrm{h})$, decreasing to about $1 \mathrm{mrem} / \mathrm{h}$ at a distance of $1 \mathrm{ft}(0.3 \mathrm{~m})$.

As was the case for chemical toxicity, the extent of radiological exposure to a depleted uranium compound depends on the solubility of the compound and the route of exposure. In most assessments, only inhalation or ingestion are considered. Although absorption of some soluble compounds (e.g. uranyl nitrate) through the skin is possible, such dermal exposures generally are not significant in association with industrial emissions or environmental exposures. For inhalation or ingestion of soluble or moderately soluble compounds such as $\mathrm{UO}_{2} \mathrm{~F}_{2}$ or $\mathrm{UF}_{4}$, the uranium enters the bloodstream and reaches the kidney and other internal organs, so that chemical toxicity is of primary importance. For inhalation of insoluble compounds such as $\mathrm{UO}_{2}$ and $\mathrm{U}_{3} \mathrm{O}_{8}$, the uranium is generally deposited in the lungs and can remain there for long periods of time (months or years). The main concern from exposure to these insoluble compounds is increased cancer risk from the internal exposure to radioactivity. Ingested insoluble compounds are poorly absorbed from the gastrointestinal tract, and so generally have low toxicity. 


\subsection{Waste Form Stability}

The stability of the waste form must be considered for both the operational and post-closure phases of the disposal facility. During the operational phase, hazards to facility personnel during emplacement and prior to closure should be evaluated. Operational accidents and potential package failure before all engineered barriers of the facility are in place could place workers at risk depending on the waste form stability. The ultimate post-closure stability of the disposed waste form will be decided by its interaction with the environment, primarily groundwater infiltration or possibly dispersion in air, when failure of the engineered barriers of the disposal facility occurs. Once released from the facility, further consideration must be given to the mobility of the uranium in the air, soil, and groundwater. Thus, "stable" means that the waste form will maintain its physical form, be of low reactivity, and have low mobility.

The waste acceptance criteria (WAC) at LLW disposal sites are designed to ensure that only stable waste forms are disposed. WAC at commercial disposal facilities are based, in part, on NRC regulations which are discussed in Section 3.3.2.2. Specifically, the regulations mandate certain limitations on characteristics of waste that can be disposed of in NRC-licensed facilities. DOE M 435.1-1 contains similar limitations on waste characteristics (see Section 3.3.3) that apply to DOE low-level waste disposal facilities, and are reflected in the WACs for those facilities. The waste acceptance criteria (WAC) for a number of existing LLW disposal sites are discussed in Section 4.4. One objective of the waste acceptance criteria is to ensure the safety of workers involved in the transportation and disposal of the radioactive waste. For all WAC investigated, examples of unacceptable waste forms are those that react exothermically with water, are pyrophoric, or are capable of generating quantities of toxic gases or vapors. A number of potential depleted uranium waste forms are excluded by such criteria.

\subsection{Potential Waste Forms}

All six chemical forms of depleted uranium discussed in Sections 2.1 and 2.2 were considered for disposal in the PEIS. Only two chemical forms were selected for detailed analysis, $\mathrm{U}_{3} \mathrm{O}_{8}$ and $\mathrm{UO}_{2}$. Two physical forms were evaluated for each oxide, ungrouted and grouted. Ungrouted waste refers to $\mathrm{U}_{3} \mathrm{O}_{8}$ or $\mathrm{UO}_{2}$ in the powder or pellet form produced during the conversion process. This bulk material would be disposed of in drums. Grouted waste refers to the solid material obtained by mixing the uranium oxide with cement and repackaging it in drums. Grouting is intended to increase structural strength and stability of the waste and to reduce the solubility of the waste in water. However, because cement would be added to the uranium oxide, grouting would increase the total volume requiring disposal. Grouting of waste was assumed to occur at the disposal facility.

Vitrification of depleted uranium oxides prior to disposal was considered. Technologies for vitrification of depleted uranium oxides are in the early stages of development, and vitrification would likely increase the volume of the material by 100 to $400 \%$ compared with a 50 to $100 \%$ increase for grouting. Also, the capability of vitrification to reduce the already low leachability of uranium oxide compounds is unknown. For the purposes of the PEIS, grouted waste was considered 
representative of immobilized waste forms with low leach rates. The feasibility of vitrification of uranium oxides resulting from conversion of depleted $\mathrm{UF}_{6}$ is further discussed in Swanstrom et al. (1997).

Options for disposal of depleted uranium as $\mathrm{UF}_{6}, \mathrm{UO}_{2} \mathrm{~F}_{2}, \mathrm{UF}_{4}$, and uranium metal were considered but not analyzed in detail in the PEIS. Factors that are important and were analyzed in determining the preferred chemical form for disposal of depleted uranium are potential for release, physical characteristics, and toxicity in drinking water. WAC limitations (see Section 4.4.7) automatically exclude compounds such as $\mathrm{UF}_{6}, \mathrm{UF}_{4}$, and $\mathrm{UO}_{2} \mathrm{~F}_{2}$ that will react with water to form toxic gases (other uranium compounds and HF). The long-term stability of these compounds is also not suitable for the post-closure phase because their solubility in water will lead to easy release to groundwater once containment has been breached.

$\mathrm{UF}_{4}$ is slightly soluble in water and reactive, but to a lesser degree than uranium hexafluoride. In the final EIS for the Claiborne Enrichment Center (NRC 1994a), it was noted that reaction of UF with water would produce quantities of HF which could compromise the integrity of a disposal facility and significantly disturb the environment. Some waste disposal facilities use concrete lining material, and the HF can be expected to attack the concrete, degrading the impermeability and structural stability it is intended to provide. Relaxation of current waste acceptance criteria would likely be needed for disposal of fluorides to occur.

Because of its high density, uranium metal would be expected to need less disposal space than the remaining oxide forms. However, disadvantages include higher conversion cost and lower chemical stability than the oxides. Uranium metal powder is an unstable waste form excluded by existing WAC due to its pyrophoric nature. Metal fines or chips ignite spontaneously with a rapid energy release. Hydrogen is generated in the reaction between moisture and uranium metal when insufficient oxygen is present to passivate the metal, and care must be taken to avoid accumulation of hydrogen in closed containers.

Two examples of bulk metal pyrophoricity are cited by Cooper et al. (1996) where closed metal containers were opened and nuclear fuel elements inside began to burn. In both cases, oxygen had been consumed and moisture had reacted with the bulk metal. In one case, a mild explosion occurred, thought to be ignition of the uranium hydride and then hydrogen gas as atmospheric oxygen entered the container. Solbrig et al. (1994) also lists other incidents involving fire, a mild explosion, or flashing of the corroded metal. As an example, long-term storage of stainless steel clad uranium fuel plates was problematic until the fuel was placed under an ultra-dry nitrogen atmosphere with an irreversible water getter material (Solbrig et al. 1994).

Water attacks bulk uranium metal slowly at room temperature and rapidly at higher temperatures; $\mathrm{UO}_{2}$ and $\mathrm{U}_{3} \mathrm{O}_{8}$ are formed, heat is generated, and the metal swells and disintegrates. During the post-closure phase of a disposal facility, reaction of groundwater with the metal in the absence of oxygen (air) could lead to potential fire and explosion hazards with the formation of the metal hydride and $\mathrm{H}_{2}$ gas as the metal corrodes. As a result, any future attempts at retrieving the metal or inadvertent intrusion into the disposal facility could prove dangerous. 
Disposal of bulk depleted uranium ordnance by the Army at the Nevada Test Site has occurred (Hertzler et al. 1994), but the bulk uranium was encapsulated in concrete (DOE 1995). Because of its higher conversion costs and reactivity, disposal as uranium metal was considered but not analyzed in detail in the engineering analysis report (LLNL 1997a) and the PEIS (DOE 1999). 


\section{REGULATORY CRITERIA}

\subsection{Introduction}

This chapter addresses the regulatory issues related to disposal of depleted uranium either in the form of an oxide $\left(\mathrm{U}_{3} \mathrm{O}_{8}\right.$ or $\left.\mathrm{UO}_{2}\right)$ or uranium metal. The disposal facility may be a shallow earthen structure, vault, or underground mine for direct disposal. The federal laws potentially applicable to land disposal of depleted uranium oxide and metal include the following:

\section{Environmental Laws and Regulations Governing Solid and Hazardous Waste Management}

- $\quad$ Resource Conservation and Recovery Act (RCRA) [Pub. L. 94-580; 90 Stat. 2795]

Environmental Laws and Regulations Governing Radioactive Materials Management

- Atomic Energy Act of 1954 (AEA) [Pub. Law 83-703; 68 Stat. 919], as amended

- Clean Air Act (CAA) [Pub. L. 88-206, 77 Stat. 392], as amended

Environmental Laws and Regulations Governing Federal Agency Decisions

- National Environmental Policy Act (NEPA) [Pub. L. 91-190; 83 Stat. 852], as amended

In addition to complying with the federal laws listed above, it is likely that the industrial area associated with a disposal facility accepting depleted uranium would require a permit to discharge storm water, and possibly other wastewaters. The National Pollutant Discharge Elimination System (NPDES) program, which was established by section 402 of the Federal Water Pollution Control Act, as amended by the Clean Water Act of 1977 (CWA) [Pub. L. 95-217], requires such permits. EPA authorizes States that adopt requirements at least as stringent as the minimum federal program [40 CFR Part 122, "EPA Administered Permit Programs: The National Pollutant Discharge Elimination System"] to implement the program within their boundaries. Also under the CWA (section 404), if construction activity associated with a disposal facility would require dredging or placement of fill material in waters of the United States, including areas designated as wetlands, then a permit would have to be obtained from the U.S. Army Corps of Engineers [33 CFR Part 323, "Permits For Discharges Of Dredged Or Fill Material Into Waters Of The United States."].

The remainder of this chapter summarizes legal requirements that would be imposed on land placement of uranium oxides and metal by the RCRA, AEA, CAA, and NEPA statutes and their implementing regulations. Pertinent regulatory interpretations issued by responsible regulatory agencies are also reported. Legal requirements that would apply if depleted uranium were disposed directly as uranium hexafluoride $\left(\mathrm{UF}_{6}\right)$ or uranium tetrafluoride $\left(\mathrm{UF}_{4}\right)$ are not discussed because depleted uranium in such forms has characteristics unacceptable for direct disposal (see Section 2.5). 


\subsection{Environmental Laws and Regulations Governing Solid and Hazardous Waste Management}

When discussing the applicability of the Resource Conservation and Recovery Act (RCRA) to disposal of depleted uranium, it is important to understand that RCRA expressly excludes materials subject to the AEA from its definitions of solid and hazardous waste. [RCRA §1004(27); 42 U.S.C. 6903(27)] AEA materials include source material, special nuclear material, and byproduct material. Accordingly, if any form of depleted uranium falls within the AEA definitions of these materials, it should not be subject to RCRA, or any state or federal regulations that implement RCRA.

Appendix A presents the AEA definitions of source material, special nuclear material, and byproduct material, and analyzes whether chemical forms of depleted uranium included in the DOE inventory qualify as any of these materials. DOE's inventory of depleted uranium contains purified chemical forms. The vast majority (greater than 95 percent) is depleted $\mathrm{UF}_{6} \cdot \mathrm{UO}_{3}$ represents most of the non- $\mathrm{UF}_{6}$ depleted uranium, amounting to around 3 percent of the DOE inventory. About one percent is depleted uranium metal, and the remainder is $\mathrm{UF}_{4}$ (DOE 1996a). Appendix A concludes that these purified forms of depleted uranium are source material because all are uranium or chemical compounds of uranium. This means that RCRA should not apply to storage or conversion of any depleted uranium in DOE's inventory. Notwithstanding, State regulatory agencies responsible for implementing RCRA in Ohio and Tennessee have taken a contrary position regarding depleted $\mathrm{UF}_{6}$ stored at DOE sites within their State's boundaries.

Appendix D describes the Ohio and Tennessee situations. Kentucky, which also hosts a DOE depleted $\mathrm{UF}_{6}$ storage site, has expressed no official position on the issue.

As Appendix D explains, some possibility exists that DOE might end up evaluating whether depleted $\mathrm{UF}_{6}$ being stored at the Portsmouth Gaseous Diffusion Plant in Ohio is solid and hazardous waste. Presently, a lack of information makes the outcome of such an evaluation difficult to predict. Therefore, without conceding that RCRA applies to depleted $\mathrm{UF}_{6}$, Appendix D discusses how regulatory requirements applicable to disposal of depleted uranium oxides and metal generated by conversion of depleted $\mathrm{UF}_{6}$ would be affected if depleted $\mathrm{UF}_{6}$ is hazardous waste in Ohio. Importantly, the discussion in Appendix D provides information for decision-making purposes only. In no way does inclusion of Appendix D in this report imply that DOE accepts the notion that depleted uranium in any form stored at a DOE site is subject to RCRA.

\subsection{Environmental Laws and Regulations Governing Radioactive Materials Management}

The Atomic Energy Act of 1954, as amended, is the basic law governing production of, use of, ownership of, liability for, and disposal of radioactive materials in the United States. Other laws also specify radioactive waste management procedures and authorities, which supplement the AEA. Among these laws are the Nuclear Waste Policy Act of 1982 (NWPA) [Pub. L. 97-425; 96 Stat. 2201; 42 U.S.C. $\$ \$ 10101-10270]$, the Low-Level Radioactive Waste Policy Amendments Act of 


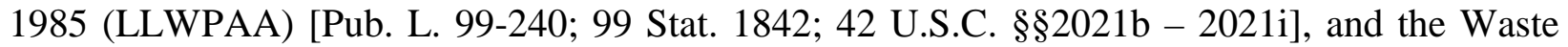
Isolation Pilot Project Land Withdrawal Act of 1992 [Pub. L. 102-579; 106 Stat. 4777].

Regulatory requirements applicable to disposal of a discarded radioactive material are dictated by the category of radioactive waste into which the material falls. The NWPA, the LLWPAA, and the WIPP Land Withdrawal Act define four categories of radioactive waste, which include high-level radioactive waste, spent nuclear fuel, transuranic waste and low-level radioactive waste. Byproduct material defined by the AEA $\$ 11(\mathrm{e})(2)$ (uranium and thorium mill tailings) is also a category of radioactive waste. The NRC regulations codify definitions of the radioactive waste categories in Code of Federal Regulations, Title 10, Parts 40, 60, 61, and 72. [see 10 CFR Part 61, "Licensing Requirements for Land Disposal of Radioactive Wastes"] DOE has adopted the definitions in DOE orders (see Section 3.3.3). ${ }^{1}$ Table 3.1 provides the statutory definitions, along with the corresponding NRC and DOE definitions. Appendix B evaluates into which category of radioactive waste shown on Table 3.1 discarded depleted uranium oxides and metal would fall.

Appendix B concludes that discarded depleted uranium oxides and metal destined for disposal would be low-level radioactive waste. Hence, if DOE decides that long term management of depleted UF6 should include permanent disposal, such disposal must be conducted according to DOE policies regarding disposal of low-level radioactive waste. DOE states this policy in the implementation manual [DOE M 435.1-1. Radioactive Waste Management Manual (1999)] to Order DOE O 435.1, Radioactive Waste Management (1999). Chapter I, section 2.F(4) of the implementation manual states that, DOE-generated low-level waste must be "disposed of at the site where the waste is generated, if practical; or at another DOE facility." However, Field Element Managers have authority to grant exemptions to this rule if DOE disposal capabilities are not practical or cost effective.

\subsubsection{Background}

Initially, the AEA gave broad powers to the Atomic Energy Commission (AEC), predecessor agency to DOE and NRC, for controlling all aspects of the use of source material, special nuclear material, and byproduct material. During the early and middle 1950s, under such authority, the AEC disposed of nuclear wastes generated by the few organizations outside the agency that were licensed to possess such nuclear materials. During the late 1950s, the AEC licensed several firms to provide ocean disposal of certain radioactive wastes. In 1960, at the urging of companies in the private sector, the AEC announced that it would license land disposal facilities, and would phase out the use of AEC facilities for disposal of commercially generated low-level radioactive wastes. (DOE 1996b).

1 The AEA, as amended, authorizes DOE to prescribe any policies, standards, criteria, procedures, rules and regulations necessary or appropriate to carry out its vested functions [Energy Reorganization Act of 1974, Pub. L. 93-438 (88 Stat. 1233), §105(a) (1974)], which include management of radioactive wastes. Pursuant to that authority, DOE has adopted a series of internal orders. These orders apply with respect to DOE facilities in a manner similar to NRC regulations with respect to commercial nuclear facilities. Through contract provisions, DOE can enforce the requirements in DOE order against contractors who operate DOE installations. 
During the 1960s and 1970s, the NRC (or its predecessor, the AEC) licensed six commercially-operated low-level waste disposal facilities under AEA authority. ${ }^{1}$ Meanwhile, under its own AEA authority, DOE regulated low-level waste disposal at DOE sites.

In the middle to late 1970 s, three of the NRC-licensed commercially-operated low-level waste disposal facilities closed prematurely for failure to perform up to expectations. Concerned that the remaining three disposal sites might alone be required to meet the national demand for disposal capacity indefinitely, the political leaders in Nevada, South Carolina, and the State of Washington urged Congress to adopt Federal legislation that would encourage states to take responsibility for their own waste. Accordingly, in 1980, Congress enacted the Low-Level Radioactive Waste Policy Act (LLWPA) [Pub. L. 96-573; 42 U.S.C. $\$ \$ 2021$ b et seq. (1980)], which assigned each State the responsibility to provide for disposal of most commercially generated low-level radioactive waste within its boundaries. To accomplish this, States were authorized to form regional compacts. Upon approval by Congress, each compact was allowed, beginning in 1993, to restrict the import into its low-level waste disposal facilities of low-level waste from states located outside the compact. Unfortunately, the creation of new low-level waste disposal sites did not progress very quickly under the LLWPA. Consequently, in 1986, Congress passed the Low-Level Radioactive Waste Policy Amendments Act of 1985 (LLWPAA) [Pub. L. 99-240; 99 Stat. 1842; 42 U.S.C. $§ 2021 b-2021$ i (1986)], which amended the LLWPA by giving the States with existing disposal sites (i.e., Washington and South Carolina) the power to add surcharges to disposal costs on wastes from States that did not meet specified deadlines. Further, the States with existing disposal facilities were empowered to eventually exclude waste from such States. The NRC's responsibility for licensing and regulating commercially-operated low-level radioactive waste disposal facilities was not changed. [42 U.S.C. §2021d(b)(3)] In addition, DOE remains responsible for regulating low-level waste disposal at DOE facilities. [42 U.S.C. §2021c(b)(1)]

The EPA, although it has no jurisdiction over specific facilities that manage radioactive materials, is responsible for protecting public health and the environment by, among other things, promulgating radiation protection standards for implementation by DOE and NRC with respect to facilities under their respective jurisdictions. [Energy Reorganization Plan No.3 of 1970 (prepared by the President and transmitted to the Senate and the House of Representatives pursuant to chapter 9 of title 5 of the United States Code) (July 9, 1970)] Additionally, EPA is responsible for promulgating standards for radioactive releases into the environment.

States may also have limited authority to regulate radioactive materials, either directly under state law, or under authority delegated by a federal agency such as the NRC or EPA.

1 The six original low-level radioactive waste disposal facilities and their operating dates were: Beatty, Nevada (1962-1992); West Valley, New York (1963-1975); Maxey Flats, Kentucky (1963-1977); Richland, Washington (1965- Present); Sheffield, Illinois (1968-1978); and Barnwell, South Carolina (1971- Present). At the times when these facilities were licensed, the AEC/NRC had no specific regulations in place governing licensing of low-level radioactive waste disposal facilities. Subsequently, the NRC promulgated 10 CFR Part 61, "Licensing Requirements for Land Disposal of Radioactive Waste"(47 FR 57446; December 27, 1982) in response to needs and requests expressed by the public, the Congress, industry, the States, the NRC Commissioners, and other Federal agencies. 
Since Congress enacted the LLWPAA in 1986, no states or compacts have successfully sited or brought online new low-level waste disposal facilities (Blake 1999). As a result, Chem-Nuclear Systems Inc.'s Barnwell, South Carolina facility (see Section 4.4.3) and U.S. Ecology's Hanford, Washington facility (see Section 4.4.5), which were both already operating in 1986, remain the only two low-level waste disposal sites in the United States developed by a state or compact under the LLWPAA. To the extent that other new commercially-operated low-level waste disposal capacity exists, it has been developed by strictly commercial ventures. One such facility is the Envirocare of Utah facility at Clive, Utah. This facility was originally authorized to accept uranium and thorium mill tailing. Over the years, it gained permission under NRC and State license to receive other kinds of radioactive waste, including naturally occurring material and various radionuclides (see Section 4.4.4). Waste Control Specialists (WCS) operates another commercial facility in Andrews County, Texas. This facility is seeking the NRC/Agreement State licenses it needs to dispose of low-level radioactive and mixed wastes. However, at present, it has approval only to treat, process, and store such wastes, not dispose of them (see Section 4.4.6).

Sections 3.3.2 and 3.3.3, below, describe the regulatory programs established under the AEA and the LLWPAA for disposal of low-level waste at non-DOE and DOE facilities, respectively. Section 3.3.4 describes standards established by EPA for radioactive releases. Section 3.3.5 describes the role of Agreement States in regulating low-level waste disposal.

\subsubsection{Requirements for Disposal of Low-Level Wastes at Non-DOE Facilities}

\subsubsection{DOE M 435.1-1, Radioactive Waste Management Manual}

As previously mentioned, DOE policy prohibits disposal of DOE-generated low-level radioactive waste in non-DOE facilities, unless DOE disposal capabilities are not practical or cost ffective, and the responsible DOE Field Element Manager approves an exemption. A DOE Field Element Manager may grant an exemption only after the following prerequisites are fulfilled [DOE M 435.1-1 at §I.2.F(4)]:

- The non-DOE facility:

- Complies with applicable Federal, State, and local requirements;

- Possesses the necessary permit(s), license(s), and approval(s) for the specific wastes; and

- Has been determined by the Field Element Manager to be acceptable based on a review conducted annually by DOE.

- The responsible DOE Field Element confirms and documents that use of the proposed nonDOE facility is cost effective and in the best interest of DOE, taking into consideration (1) the alternatives of on-site disposal, off-site disposal at other DOE sites, and off-site disposal at other non-DOE facilities; (2) life-cycle cost and potential liability; and (3) protection of public health and the environment.

- The responsible DOE Field Element sufficiently characterizes the low-level waste and certifies that it meets the waste acceptance criteria of the proposed non-DOE facility.

- DOE completes the appropriate review required by the National Environmental Policy Act NEPA). 
- The responsible DOE Field Element consults the Office of the Assistant Secretary for Environment, Safety and Health (EH-1) before executing the exemption and notifies each appropriate DOE Headquarters Office when the exemption is approved.

- The responsible DOE Field Element consults the Host State and State Compact where the non-DOE facility is located before granting the exemption, and notifies them before shipments are made.

Hence, unless DOE establishes an alternative policy for disposal of low-level waste generated by conversion of depleted $\mathrm{UF}_{6}$, the responsible DOE Field Element Manager must ensure that DOE completes the prerequisites listed above before disposal of uranium oxides or metal can move forward at a non-DOE low-level radioactive waste disposal facility.

\subsubsection{NRC Regulations (10 CFR Part 61)}

The NRC or an Agreement State typically licenses non-DOE low-level radioactive disposal facilities under 10 CFR Part 61, "Licensing Requirements for Land Disposal of Radioactive Wastes." However, in limited circumstances, DOE may regulate them. ${ }^{1}$ DOE's regulatory program is described in Section 3.3.3, below. Section 3.3.5 describes the role of Agreement States. The requirements imposed by 10 CFR Part 61 on low-level waste disposal facilities are summarized in this section. This discussion assumes that depleted uranium oxides and metal will not be regulated as mixed waste (see Section 3.2, above).

Among other things, 10 CFR Part 61, Subpart D, "Technical Requirements for Land Disposal Facilities," establishes a classification system for evaluating whether radioactive wastes are suitable for near-surface disposal, and for assigning appropriate waste form and stability requirements. [10 CFR §61.55] This classification system is based on the amount of radioactivity in waste that results from radionuclides listed in 10 CFR Part 61, Tables 1 and 2. Table 1 lists certain long-lived radionuclides and Table 2 lists certain short-lived radionuclides. Three classes of radioactive waste $(\mathrm{A}, \mathrm{B}$, and $\mathrm{C}$ ) are defined as eligible for near-surface disposal. Wastes having more radioactivity than the upper bound of Class C (i.e., "greater than Class C wastes") are generally unacceptable for near-surface disposal.

The NRC has listed no form of uranium on either Table 1 or Table 2. A radioactive waste that does not contain any radionuclide listed on Tables 1 and 2 is designated as Class A. [10 CFR $\S 61.55(a)(6)]$ Hence, under the NRC classification system, depleted uranium oxides and uranium metal are Class A low-level radioactive wastes. As such, uranium oxides and metal would be eligible for near-surface disposal, provided the disposal facility meets the performance objectives and applicable technical standards in 10 CFR Part 61.

\footnotetext{
${ }^{1}$ AEA $§ 110(a)(2)$ excludes privately owned, privately operated facilities from the requirement to obtain NRC licenses if the facilities are constructed or operated under contract with and for the account of DOE. (See Waste Control Specialists, LLC v. DOE, $141 \mathrm{~F} .3^{\text {rd }} 564\left(5^{\text {th }}\right.$ Cir. 1998) (stating that all parties agreed that DOE could lawfully regulate a privately owned, privately operated low-level waste disposal facility located on private property in Texas). Accordingly, when certain conditions are met, NRC regulations exempt the DOE prime contractor and certain subcontractors from the requirement to obtain an NRC license [10 CFR $\S \S 30.12,40.11$, and 70.11].
} 
10 CFR Part 61, Subpart C, "Performance Objectives," contains performance objectives applicable to any method of low-level waste disposal (not just near-surface disposal). Depleted uranium disposal in a non-DOE low-level waste disposal facility using any of the methods currently being considered (i.e., shallow earthen structure; engineered vault; or underground mine) would thus be required to comply with these performance objectives. Table 3.2 lists the performance objectives that apply to all low-level waste disposal facilities.

One example of an NRC evaluation of a low-level waste disposal facility's ability to meet the performance criteria in 10 CFR Part 61, Subpart C involved the Claiborne Enrichment Center, a uranium enrichment facility proposed to be located near Homer, Louisiana. (NRC 1994a). In that case, the NRC evaluated environmental impacts of disposing $\mathrm{U}_{3} \mathrm{O}_{8}$ in a near-surface disposal facility at a wet location, and in a deep disposal facility at two locations in different geological settings.

For the near-surface disposal alternative, the NRC used infiltration rate and aquifer flow rate values for a humid southeastern site location. Other assumptions in the NRC's analysis were: that the near surface disposal unit would be a tumulus with a 2-meter compacted clay cover; that the $\mathrm{U}_{3} \mathrm{O}_{8}$ particles would have a mean diameter on the order of 50 microns; and that the disposed $\mathrm{U}_{3} \mathrm{O}_{8}$ would be spread in the disposals unit so as to occupy a volume assumed to be 8 meters thick, 61 meters long and 61 meters wide. The NRC concluded that the estimated doses for release from such a nearsurface depleted $\mathrm{U}_{3} \mathrm{O}_{8}$ disposal facility would be significantly above the performance standard established in 10 CFR 61.41 for protection of the general population from releases of radioactivity. Accordingly, the final EIS concluded that disposal of depleted $\mathrm{U}_{3} \mathrm{O}_{8}$ from the Claiborne Enrichment Center would need to be in a unit other than a near-surface disposal unit (pp. 4-66 to 4-68 in NRC 1994a). The final EIS suggested a deep disposal unit would be an example of such a unit.

For deep disposal of $\mathrm{U}_{3} \mathrm{O}_{8}$ from the Claiborne Enrichment Center, the NRC calculated peak doses at two site geological settings. In the first setting, the $\mathrm{NRC}$ assumed that $\mathrm{U}_{3} \mathrm{O}_{8}$ would be placed at 290 meters below the ground surface in a granite formation intersected by vertical fractures. In the second setting, the NRC assumed that $\mathrm{U}_{3} \mathrm{O}_{8}$ would be placed at 635 meters below the ground surface at a location where local upward groundwater flow would carry water through the $\mathrm{U}_{3} \mathrm{O}_{8}$ matrix to a cemented sand and gravel strata which would intersect a river. At both sites, the final EIS found that peak doses would be less than the performance objective in 10 CFR Part 61.41. (p. A-14 in Appendix A of NRC 1994a).

The conclusion in the Claiborne Enrichment Center final EIS about near-surface disposal of depleted $\mathrm{U}_{3} \mathrm{O}_{8}$ should not be interpreted as a generic determination by the NRC that disposal of depleted $\mathrm{U}_{3} \mathrm{O}_{8}$ (or any other form of uranium) in a near-surface disposal unit is unacceptable in all circumstances. For each particular disposal facility, the final determinant of acceptability is whether compliance with the performance objectives in 10 CFR Part 61, Subpart C can be demonstrated, given the expected environmental setting.

If DOE decides to dispose of depleted uranium oxides or metal in a non-DOE facility, the NRC or Agreement State will have to evaluate the non-DOE facility's compliance with the performance objectives in 10 CFR Part 61 before issuing a license. To ensure compliance, the facility's license would specify applicable technical requirements. Typically, these would conform to 10 CFR Part 61, Subpart D, "Technical Requirements for Land Disposal Facilities." 
Alternatively, the NRC or the responsible Agreement State could exempt the facility from any technical requirements, or develop substitute requirements (10 CFR 61.54).

Table 3.3 summarizes specific technical requirements that apply only to near-surface disposal of low-level waste. ${ }^{1}$ Shallow earthen structures, and possibly engineered vaults, would qualify as near surface disposal units. Technical requirements for underground mines would be determined on a case-specific basis during the NRC or Agreement State licensing process.

In addition to the provisions summarized in Tables 3.2 and 3.3, 10 CFR Part 61 specifies that each low-level waste disposal facility must conduct environmental monitoring before, during, and after closure of the facility, and must prepare a corrective action plan (10 CFR 61.53). Minimum labeling requirements and limitations on waste characteristics for all classes of low-level waste, which are typically reflected in waste acceptance criteria for NRC/Agreement State-licensed facilities (see Section 4.4.7), are also mandated. Table 3.4 summarizes these.

The regulations prohibit NRC (and Agreement States) from issuing a license for disposal of radioactive waste to any facility that will receive such waste from other persons, unless the disposal facility is located on Federal- or State-owned land (10 CFR 61.59). After closure, the government landowner or custodial agency must carry out an institutional control program to physically control access to the disposal site. The NRC (or Agreement State) will determine the period of required institutional controls.

\subsubsection{Requirements for Disposal of Low-Level Wastes at DOE Facilities}

Under the AEA, DOE has responsibility for managing facilities within the nuclear weapons complex. This responsibility includes self-regulation to protect worker and public health and safety from radiological, chemical, and physical hazards posed by such facilities during construction, operation, and decommissioning. The DOE implements self-regulation through a system of Orders that it imposes on contractors through contract provisions and which, in many cases, are also directly applicable to DOE personnel. Unlike regulations, Orders are typically consensus documents prepared by the DOE with limited or no public involvement, other than comments received from DOE contractors. In the early 1990s, the DOE initiated a process whereby the rules contained in Orders dealing with facility safety, worker health and safety, and environmental protection are being promulgated using public notice and comment procedures as specified by the Administration Procedure Act. [5 U.S.C. $\S \S 551$ to 559] The Price-Anderson Act Amendments of 1988 [Pub. L. $100-408$ at $\$ 17 ; 102$ Stat. 1066] authorized DOE to enforce promulgated nuclear safety regulations by levying fines and referring criminal matters to the Department of Justice for prosecution.

As non-reactor nuclear facilities, DOE radioactive waste management facilities are governed by promulgated DOE regulations and a collection of DOE Orders, manuals, and guidance documents which apply pursuant to valid contracts. DOE Orders and promulgated DOE regulations that may

\footnotetext{
${ }^{1}$ Near-surface disposal involves disposal in the uppermost portion of the earth (i.e., within approximately 30 meters of the surface. It includes disposal in engineered facilities that may be built totally or partially above-grade, provided that such facilities have protective earthen covers. Near-surface disposal does not include disposal facilities that are partially or fully above-grade with no protective earthen cover. Those facilities are referred to as "above-ground disposal." [10 CFR §61.7(a)(1)]
} 
contain requirements applicable to low-level waste disposal facilities include, but are not limited to, those listed in Table 3.5. It should be noted, however, that any requirement contained in a directive listed in Table 3.5 may be waived or modified through application of a DOE-approved requirements tailoring process, or by exemption (see DOE M 435.1-1, §I.1.E).

Order DOE O 435.1, Radioactive Waste Management, forms the cornerstone of DOE's program to ensure that all DOE radioactive waste management activities protect worker and public health and safety, and the environment. DOE approved Order DOE O 435.1 on July 9, 1999. The requirements in Order DOE O 435.1 apply to all new and existing DOE radioactive waste management facilities, operations, and activities. Compliance is required by July 9, 2000, unless the responsible Program Secretarial Officer grants an extension. Until a DOE radioactive waste management facility has fully implemented Order DOE O 435.1, the facility must continue to comply with Order DOE 5820.2A, which was the predecessor of DOE O 435.1.

The issuance of Order DOE O 435.1 was accompanied by issuance of a manual, DOE M 435.1-1, that further describes the requirements of the Order and establishes specific responsibilities for implementing the Order. The manual catalogs the procedural requirements and existing practices that DOE elements and contractors must employ to ensure compliance with the Order. The new Order and manual were not intended to change the substantive requirements of DOE 5820.2A. Rather, the revisions reflected in the new Order and manual include such procedural changes as: requiring more headquarters involvement in reviewing and approving low-level waste disposal facility performance assessments; delegating additional authorities to field-level managers; requiring maintenance of operating basis procedures; and placing greater emphasis on performancebased requirements rather than prescriptive requirements.

Each DOE low-level waste generator, treatment facility, storage facility, and disposal facility must have a radioactive waste management basis. Such bases consist of physical and administrative controls to ensure the protection of workers, the public, and the environment [DOE M 435.1-1, $\S I V . D]$. The specific waste management controls that must be part of the radioactive waste management basis for a disposal facility are the performance assessment, composite analysis, disposal authorization statement, closure plan, waste acceptance requirements, and monitoring plan [DOE M 435.1-1, §IV.D(4)]. These requirements are further described in Table 3.6. Any facility that fails to establish, maintain, or operate consistent with its basis is subject to curtailment of operations or shutdown [DOE M 435.1-1, §IV.F(2)].

DOE low-level waste disposal facilities are required to specify waste acceptance criteria, and to establish a process for the disposition of non-conforming wastes. The waste acceptance criteria must address at least the topics listed in Table 3.7.

Sites for DOE low-level waste facilities must be evaluated to identify environmental characteristics, geotechnical characteristics, and human activities that could affect facility design and analyses. A site with features that would prevent the facility design from providing adequate protection must be deemed unsuitable. [DOE M 435.1-1, §IV.M(1)]

DOE low-level waste disposal facilities must be designed to meet at least the design requirements listed on Table 3.8. Siting, design, operation, maintenance, and closure of DOE low- 
level waste disposal facilities must provide a reasonable expectation that the performance objectives listed on Table 3.9 will be met for wastes placed into such facilities after September 26, 1988. Additional operating requirements imposed on each DOE-regulated low-level waste disposal facility include the following [DOE M 435.1-1, §IV.P(6)]:

- Operating procedures must be developed.

- Monitoring wells and disposal excavations must be permanently marked.

- Waste and waste containers must be placed to minimize voids.

- Voids that occur must be filled to the extent practical.

- Waste disposal activities must not adversely affect other disposal units.

- Waste location in the facility must be documented and tracked by generator.

\subsubsection{Clean Air Act (CAA)}

Section 112 (National Emission Standards for Hazardous Air Pollutants (NESHAPs)) of the Clean Air Act (CAA) of 1970 [Pub. L. 91-604; 42 U.S.C. §7401 et seq.], as amended, requires EPA to list categories and subcategories of major sources and area sources of certain hazardous air pollutants, including radionuclides, and to establish emission standards for such sources [42 U.S.C. $\$ 7412$ (c)]. Among the emission standards established by EPA pursuant to these requirements are standards for DOE facilities emitting radionuclides other than radon [40 CFR Part 61, Subpart H], and standards for DOE facilities emitting radon [40 CFR Part 61, Subpart Q]. These emission standards would apply to DOE low-level waste disposal facilities, since a "facility" is defined simply to mean "all buildings, structures and operations on one contiguous site." [40 CFR §61.91(b)]

Emissions of radionuclides other than radon from DOE facilities are limited to less than the amount that would cause any member of the public to receive in any year an effective dose equivalent of 10 mrem per year. [40 CFR §61.92] Radon emissions into the air from DOE facilities are limited to no more than $20 \mathrm{pCi} / \mathrm{m}^{2}-\mathrm{s}$ of radon-222 as an average for the entire source. [40 CFR $\S 61.192]$ DOE has adopted standards applicable to DOE low-level waste disposal facilities that are consistent with these NESHAPs. [DOE M 435.1-1, §IV.P(1)]

Any fabrication, erection or installation of a new building or structure within a DOE facility that emits radionuclides is defined as new construction. [40 CFR 61.96(a)] Before such new construction begins, approval for the construction must be obtained from EPA [40 CFR 61.07], unless the construction is exempt. Construction within an existing facility that emits radionuclides is exempt from the requirement to obtain construction approval if the effective dose equivalent, caused by all emissions from the new construction or modification, is less than an effective dose equivalent in any year of 0.1 mrem per year. [40 CFR $§ 61.96(b)]$

Regarding radionuclide emissions from facilities licensed by the NRC, the CAA allows EPA to determine, by rule, and after consultation with the NRC, that the NRC's regulatory program provides an ample margin of safety to protect the public health. [42 U.S.C. §7412(d)(9)] On December 30, 1996, EPA published in the Federal Register its determination that the NRC regulatory program for licensed facilities other than commercial nuclear power reactors protects public health with an ample margin of safety. [61 FR 68972] Therefore, NRC-regulated low-level waste disposal facilities are not subject to any NESHAPs emission standards for radionuclides. 


\subsubsection{Role of States}

\subsubsection{Atomic Energy Act of 1954}

Section 274b of the AEA (42 U.S.C. \$2021(b)) authorizes the NRC to enter into an agreement with any State governor under which the State assumes authority to regulate materials covered by the agreement. States entering into such agreements with the NRC are referred to as "Agreement States." The materials that Agreement States are allowed to regulate include byproduct materials, source materials, and special nuclear materials in quantities not sufficient to form a critical mass. The NRC regulations implementing AEA §274b are contained in 10 CFR Part 150, "Exemptions and Continued Regulatory Authority in Agreement States and in Offshore Waters Under Section 274." Under 10 CFR Part 150, persons in Agreement States are exempt from NRC licensing requirements for materials covered by the NRC/State agreement. [10 CFR $\$ 150.10]$ Instead, the licensing requirements of the Agreement State apply. Hence, non-DOE low-level waste disposal facilities would be exempt from NRC licensing requirements in Agreement States that have adopted State licensing requirements for such facilities [see 10 CFR $\$ 61$. , which indicates that the NRC licensing requirements for land disposal of radioactive waste apply to all persons in the United States, except as provided in 10 CFR Part 150].

\subsubsection{Clean Air Act}

Section 112 of the CAA, as amended, allows a State to develop and submit to EPA for approval a program for the implementation and enforcement of the NESHAPs. The program submitted by a State may provide for partial or complete delegation of EPA's authorities and responsibilities, but can not allow the State to set standards less stringent than those promulgated by EPA. Notwithstanding, the State may set standards that are more stringent than those promulgated by EPA. [40 CFR $\$ 61.17]$

DOE low-level waste disposal facilities located in States having approved State programs would be subject to any State hazardous air pollutant emission standards for radionuclide emissions that were applicable under the State programs. However, as discussed in section 3.3.4, above, nonDOE low-level waste disposal facilities licensed by the NRC or an Agreement State would not be subject to NESHAPs.

\subsection{Environmental Laws and Regulations Governing Federal Agency Decisions}

\subsubsection{National Environmental Policy Act (NEPA)}

The National Environmental Policy Act of 1969 (NEPA) [Pub. L. 91-190; 42 U.S.C. $\$ 4321$ et seq.], as amended, requires that a federal agency prepare an environmental impact statement (EIS) before taking any "major federal action significantly affecting the quality of the human environment." [NEPA $\S 102(C), 42$ U.SC. $\$ 4332(C)]$ To guide compliance, many federal agencies have adopted NEPA implementing regulations. DOE's implementing regulations are located in 10 CFR Part 1021, "National Environmental Policy Act Implementing Procedures." These regulations apply to DOE's decision to dispose of depleted uranium oxides or metal, as well as to the Department's decision to construct a particular low-level waste disposal facility. The NRC's implementing regulations are located in 10 CFR Part 51, "Environmental Protection Regulations for 
Domestic Licensing and Related Regulatory Functions." These regulations would apply to the NRC's decision to issue a license to a non-DOE low-level waste disposal facility to which DOE may decide to send depleted uranium oxides or metal for disposal.

DOE takes a tiered approach to meeting its NEPA responsibilities. In the case of depleted uranium management, first, a Programmatic EIS has been prepared to address policy issues related to managing the depleted uranium hexafluoride inventory. [Programmatic Environmental Impact Statement for Alternative Strategies for the Long-Term Management and Use of Depleted Uranium Hexafluoride (DOE 1999)]. Next, individual actions taken by DOE to implement the Record of Decision, such as construction of DOE low-level waste disposal units at specific sites, will be evaluated to determine the level of NEPA review needed for each action. Three levels of review are possible for typical individual actions: (1) categorical exclusion; (2) environmental assessment (EA); and (3) EIS. [10 CFR §1021.300(a)].

DOE has simplified the selection of the appropriate level of review for individual actions by identifying, in advance, the level usually needed for various classes of individual actions. Appendices B, C., and D to 10 CFR $\S 1021$, subpart D, "Typical Classes of Actions," list typical classes of DOE actions that, respectively, (1) are categorically excluded from any requirement to prepare either an EA or an EIS; (2) normally require an EA, but not necessarily an EIS; and (3) normally require an EIS. Construction of a new DOE low-level waste disposal unit is unlikely to fall within a categorical exclusion. Therefore, either an EA or an EIS is the likely level of NEPA review that would be required.

If an EA is prepared, there are two possible outcomes: (1) no significant impact is identified that would result from constructing the new DOE low-level waste disposal unit; or (2) the construction of the new DOE low-level waste disposal unit may significantly affect the human environment, making preparation of an EIS necessary. In either case, the public must be notified and the Finding of No Significant Impact (FONSI) or EA must be made available in accordance with 40 CFR §1506.6, "Public Involvement.” [10 CFR §1021.301(a)] If the EA concludes that an EIS would be appropriate, then an EIS must be prepared in accordance with the requirements of the Council on Environmental Quality (CEQ) regulations. ${ }^{1}$ The CEQ regulations governing preparation of an EIS are contained in 40 CFR Part 1502, "Environmental Impact Statement."

NRC's approach to meeting its NEPA responsibilities is similar to DOE's approach. NRC has classified its licensing and regulatory actions into three categories: (1) actions requiring EISs [10 CFR §51.20(b)]; (2) categorical exclusions [10 CFR §51.22(c)]; and (3) actions requiring EAs [10 CFR §51.21]. According to this system, NRC classifies issuance of a license authorizing receipt and disposal of radioactive waste from other persons pursuant to 10 CFR Part 61, "Licensing Requirements for Land Disposal of Radioactive Waste," as an action requiring an EIS. [10 CFR $\S 51.20(b)(12)]$ Hence, to support preparation of the EIS, each applicant for a license under 10 CFR Part 61 is required to submit with the application a separate document entitled "Applicant's Environmental Report - License for Land disposal of Radioactive Waste." [10 CFR §51.62(a)] The

\footnotetext{
${ }^{1}$ NEPA requires all federal agencies to identify and develop, in consultation with the Council on Environmental Quality (CEQ), methods and procedures for implementing NEPA. CEQ is a three member council appointed by the President in accordance with $\$ 202$ of NEPA [42 U.S.C. §4342].
} 
Feasibility Assessment

procedures that the NRC follows in preparing the EIS after receiving the license application are contained in 10 CFR $\$ \$ 51.70$ through 51.123 . 


\section{DISPOSAL FACILITIES}

Only $\mathrm{UO}_{2}$ and $\mathrm{U}_{3} \mathrm{O}_{8}$, ungrouted or grouted, were considered stable enough forms of uranium for disposal in the EAR (LLNL 1997a) and in the PEIS (DOE 1999) as discussed in Section 2.5. As analyzed in the PEIS for disposal of the entire depleted $\mathrm{UF}_{6}$ inventory considered (700,000 MT which includes the USEC generated DU), the $\mathrm{U}_{3} \mathrm{O}_{8}$ and $\mathrm{UO}_{2}$ would be packaged for disposal as follows:

- $\quad \mathrm{U}_{3} \mathrm{O}_{8}$ would be disposed of in 55-gal (208-L) drums. If ungrouted, approximately 945,000 drums would be required; if grouted, approximately 1,980,000 drums would be required.

- $\mathrm{UO}_{2}$ would be disposed of in 30-gal (110-L) drums. These small drums would be used because of the greater density of $\mathrm{UO}_{2}$ - a filled 30-gal (110-L) drum would weigh about 2,350 lb (1,070 $\mathrm{kg}$ ). If ungrouted, approximately 556,000 drums would be required; if grouted, approximately 836,000 drums would be required. For the engineering analysis and PEIS impacts presented in this report (Sections 4, 5, and 6), the $\mathrm{UO}_{2}$ considered is obtained from depleted $\mathrm{UF}_{6}$ using the gelation process rather than the ceramic process (LLNL 1997a), resulting in a higher packing density and thus lower volume of waste. However, the gelation process is not yet a commercial scale process as is the ceramic process. For reference, the ceramic process would result in approximately 851,000 filled 30-gal (110-L) drums of ungrouted $\mathrm{UO}_{2}$, a $50 \%$ increase compared to 556,000 drums for the gelation process.

All disposal options would include a central wasteform facility where drums of uranium oxide would be received from the conversion facility and prepared for disposal. The wasteform facility would include an administration building, a receiving warehouse, and cementing/curing/short-term storage buildings (if necessary for grouting). If separate wasteform facilities were sited at each of the two proposed conversion facilities, added impacts would be incurred for construction of a second facility and additional transportation impacts would also be incurred for transporting the larger volume grouted waste form to the disposal facility.

Grouting of waste would be performed by mechanically mixing the uranium oxide with cement and other additives in large tanks and then pouring the mixture into drums. Once prepared for disposal (if necessary), drums would be moved into disposal units. For the grouted $\mathrm{U}_{3} \mathrm{O}_{8}$ option, the area of the wasteform facility would be approximately 9 acres (3.6 ha); for the grouted $\mathrm{UO}_{2}$ option, the area would be about 6 acres (2.4 ha). For ungrouted disposal options, only about 4 acres (1.6 ha) would be required because the facilities for grouting, curing, and additional short-term storage would not be needed.

The required disposal volumes for ungrouted and grouted $\mathrm{U}_{3} \mathrm{O}_{8}$ would be about 6.9 million $\mathrm{ft}^{3}$ and 14.5 million $\mathrm{ft}^{3}$, respectively. For the ungrouted and grouted $\mathrm{UO}_{2}$, the respective disposal volumes would be 2.2 million $\mathrm{ft}^{3}$ and 3.3 million $\mathrm{ft}^{3}$. If bulk uranium metal were to be disposed without encapsulation in concrete or some other protective packaging that would significantly increase bulk, the approximate disposal volume would be about 911,000 $\mathrm{ft}^{3}$. Using the packaging assumptions in the engineering analysis report (LLNL 1997a), the metal would be contained in 
approximately 797,000 billet boxes occupying a volume of approximately 3.2 million $\mathrm{ft}^{3}$. The packaging assumptions included billet boxes with sufficient void space to accommodate the use of existing packing equipment.

\subsection{Facility Types}

Several disposal options were considered, including disposal in shallow earthen structures ("engineered trenches"), belowground vaults, and an underground mine. A brief summary of each type is given below. This information is based on preconceptual design data provided in the depleted $\mathrm{UF}_{6}$ engineering analysis report (LLNL 1997a). The unique features of each disposal option are described in Sections 4.1.1, 4.1.2, and 4.1.3.

\subsubsection{Shallow Earthen Structures}

Shallow earthen structures, commonly referred to as engineered trenches, are among the most commonly used forms of low-level waste disposal, especially in dry climates. Shallow earthen structures would be excavated to a depth of about $26 \mathrm{ft}(8 \mathrm{~m})$, with the length and width determined by site conditions and the annual volume of waste to be disposed. Disposal in shallow earthen structures would consist of placing waste on a stable structural pad with barrier walls constructed of compacted clay. Clay would be used because it prevents the walls from collapsing or caving in, and it presents a relatively impermeable barrier to waste migration. The waste containers (i.e., drums) would be tightly stacked three pallets high in the bottom of the structure with forklifts or similar equipment. Any open space between containers would be filled with earth, sand, gravel, or other similar material as each layer of drums was emplaced. After the structure was filled, a $6 \mathrm{ft}$ ( 2 $\mathrm{m})$ thick cap composed of engineered fill dirt and clay would be placed on top and compacted. The cap would be mounded at least $3 \mathrm{ft}(1 \mathrm{~m})$ above the local grade and sloped to minimize the potential for water infiltration. Disposal of ungrouted and grouted $\mathrm{U}_{3} \mathrm{O}_{8}$ would require about 60 acres and 110 acres, respectively. Disposal of ungrouted and grouted $\mathrm{UO}_{2}$ would require about 36 acres and 50 acres, respectively.

\subsubsection{Vaults}

Below-ground vaults are subsurface reinforced concrete structures. Each vault would be divided into five sections, each section approximately $66 \mathrm{ft}(20 \mathrm{~m})$ long by $26 \mathrm{ft}(8 \mathrm{~m})$ wide and 13 $\mathrm{ft}(4 \mathrm{~m})$ tall. As opposed to shallow earthen structures, the walls and floor of a vault would be constructed of reinforced concrete. A crane would be used to place drums within each section. Once a vault was full, any open space between containers would be filled with earth, sand, gravel, or other similar material. A permanent roof slab of reinforced concrete that completely covers the vault would be installed after all five sections were filled. A cap of engineered fill dirt and clay would be placed on top of the concrete cover and compacted. The cap would be mounded above the local grade and sloped to minimize the potential for water infiltration. Disposal of ungrouted and grouted $\mathrm{U}_{3} \mathrm{O}_{8}$ would require about 98 and 194 acres, respectively. Disposal of ungrouted and grouted $\mathrm{UO}_{2}$ would require about 36 and 52 acres, respectively.

\subsubsection{Underground Mines}

An underground mine disposal facility would be a repository for permanent deep geological disposal. A mined disposal facility could possibly use a previously existing mine, or be constructed for the sole purpose of waste disposal. A mine disposal facility would consist of surface facilities that 
provide space for waste receiving and inspection (the wasteform facility), and shafts and ramps for access to and ventilation of the underground portion of the repository. The underground portion would consist of tunnels (called "drifts") for the transport and disposal of waste underground. The dimensions of the drifts considered are $21 \mathrm{ft}(6.5 \mathrm{~m})$ wide $\times 330 \mathrm{ft}(100 \mathrm{~m})$ long and $18 \mathrm{ft}(5 \mathrm{~m})$ high. Waste containers would be placed in drifts and backfilled. Disposal of ungrouted and grouted $\mathrm{U}_{3} \mathrm{O}_{8}$ would require about 306 acres and 620 acres of underground disposal space, respectively. Disposal of ungrouted and grouted $\mathrm{UO}_{2}$ would require about 134 acres and 195 acres, respectively.

\subsection{Environmental Settings Considered}

The potential environmental settings for disposal of depleted uranium were based on data representing a dry setting and a wet setting. Both the dry and wet settings were assumed to be in a rural environment with an average population density of 15 persons $/ \mathrm{mi}^{2}\left(6\right.$ persons $\left./ \mathrm{km}^{2}\right)$.

\subsubsection{Dry Environment}

For the representative dry setting, a disposal facility was assumed to be located in an arid to semiarid climate. Under these conditions, annual precipitation typically would be about $10 \mathrm{in} . / \mathrm{yr}$ ( 25 $\mathrm{cm} / \mathrm{yr}$ ). Approximately $1 \%$ of the annual rainfall (Rice et al. 1989), or about $0.1 \mathrm{in.} / \mathrm{yr}(0.25 \mathrm{~cm} / \mathrm{yr}$ ), would be expected to infiltrate the ground, recharging the groundwater. The remainder of the precipitation would be lost to runoff or evapotranspiration (evaporation plus plant transpiration). No ponded waters would be expected to occur nearby, although it was assumed for assessment purposes that a nearby river could be used to supply raw water and to receive liquid waste discharges. The area would be well drained and free of flooding or frequent ponding.

The dry setting was assumed to be in a relatively flat area, overlying approximately $500 \mathrm{ft}$ $(150 \mathrm{~m})$ of unconsolidated soil. This soil material was assumed to consist of sandy gravel and gravelly sand interbedded with lenses of clay, silt, and sand that have a variable thickness from about $1 \mathrm{ft}(0.3 \mathrm{~m})$ to more than $30 \mathrm{ft}(9.1 \mathrm{~m})$. Caliche (layers cemented together by calcium carbonate and other salts), commonly formed on exposed surfaces, would further limit infiltration. The presence of clay layers would impede vertical contaminant transport to the underlying water table. Because of the arid climate, water content of the soil would generally be less than $10 \%$ by volume. The unconsolidated material was assumed to have a limited number of small, discontinuous fractures and no significant voids or flow channels.

The groundwater aquifer was assumed to be located at a depth of about $500 \mathrm{ft}(150 \mathrm{~m})$ below the surface. This aquifer was assumed to consist of $100 \mathrm{ft}(30 \mathrm{~m})$ of semiconsolidated sands, gravels, silts, and clays.

The assessment of air dispersion following potential releases to the atmosphere was based on historical meteorological conditions for five actual "dry" locations in the southwestern United States to provide a range for impact calculations.

\subsubsection{Wet Environment}

For the generic wet setting, a disposal facility was assumed to be in a modified continental climate. Under these conditions, annual precipitation would be about $40 \mathrm{in} . / \mathrm{yr}(100 \mathrm{~cm} / \mathrm{yr})$. About 
$50 \%$ of the rainfall would be expected to be lost to runoff and evapotranspiration, with the remainder, $20 \mathrm{in.} / \mathrm{yr}(51 \mathrm{~cm} / \mathrm{yr})$, infiltrating the ground and recharging the underlying groundwater aquifer (Rice et al. 1989). Because of moderate climatic conditions, nearby surface water features would likely be present; however, the setting would be above the elevation of any 100-year floodplain. It was assumed that a nearby river would be available to supply raw water and to receive liquid waste discharges. The area was assumed to be well drained and free of areas of flooding or frequent ponding.

The wet setting was assumed to be in a relatively flat area, overlying approximately $30 \mathrm{ft}$ (9 $\mathrm{m}$ ) of unconsolidated soil. This material would consist of layers of sand, gravel, and clay. The presence of clay layers would impede vertical contaminant transport to the underlying water table. Because of frequent rainfall events, the water content of the soil would be high. The unconsolidated material was assumed to have a limited number of small, discontinuous fractures and no significant voids or flow channels. Frost penetration of the uppermost layer of soil would be less than $3 \mathrm{ft}(0.9$ $\mathrm{m})$.

The groundwater aquifer was assumed to be located at a depth of about $30 \mathrm{ft}(9 \mathrm{~m})$ below the surface. This aquifer was assumed to consist of $20 \mathrm{ft}(6.1 \mathrm{~m})$ of semiconsolidated sands, gravels, silts, and clays.

The assessment of air dispersion following potential releases to the atmosphere was based on historical meteorological conditions for five actual "wet" locations in the central and southeastern United States to provide a range for impact calculations.

\subsection{Engineered Barriers}

LLW disposal facilities must be able to isolate the disposed waste from the environment. Sites must be located in geologically stable areas away from large population centers. Disposal sites are located in areas that are not prone to flooding and are situated above the water table. The primary concern for maintaining confinement is prevention of surface water and groundwater infiltration.

Direct infiltration of rainwater into a disposal cell is typically avoided by capping the cell with a multiple layer barrier. Such a barrier includes at least one impermeable layer (such as natural clay materials, concrete, plastic sheeting or some combination) in conjunction with a layer(s) designed to provide a conduit off and away from the cell and a surface layer designed to prevent erosion of the cover material. Surface water runoff is directed away from disposal areas. Intrusion of groundwater is sometimes prevented by lining the sides and bottom of a disposal cell with an impermeable lining such as mentioned above for capping the cell (generally used for RCRA wastes). Internal drainage is often provided to direct water that has breached the cell confinement away from the waste packages.

The next barrier to water contact with the waste form once water has infiltrated a disposal cell is the waste packaging. Following failure of the packaging, the stability of the waste form in an aqueous environment (Section 2.4) is the final barrier to release of radioactive species within the cell. 
Release of contamination to the environment outside of the disposal cell can be further inhibited by the use of backfill material within the cell that has high contaminant absorption capacities.

This type of multiple barrier design, with the exception of possible sumps to aid in pumping internal drainage systems, is a passive system, ensuring confinement of disposed material such as DU for many years beyond site closure. Post-closure impacts (Sections 5 and 6) conservatively assumed failure of containment after 100 years. However, although not directly quantifiable with the currently available preliminary designs (LLNL 1997a), release of any waste to the surrounding environment would not be expected for several hundred years or more following closure because of the multiple barriers to release and dispersal discussed here.

\subsection{Potential LLW Disposal Sites}

Both commercial and DOE-owned LLW sites are available that could potentially dispose of the DU stockpile. Only currently operating sites were considered.

\subsubsection{Hanford Site}

The Hanford Site, managed by DOE, occupies approximately 560 square miles of semi-arid desert land in southeastern Washington State, of which 21,498 acres (6\%) are developed. The site is approximately 119 miles southwest of Spokane and is located northwest of the City of Richland, Washington, on the Columbia plateau. The site employs approximately 14,000 people. The site was acquired by the Federal Government in 1943. Plutonium production and storage and disposal of the resulting waste products occurred for almost 50 years. Over the years, programs at Hanford have diversified and now concentrate on research and development, waste disposal technologies, and cleanup of site contamination. Both the Waste Management program and the Environmental Restoration program operate disposal facilities at the Hanford Site. Hanford has both truck and rail access for waste shipments.

The 200 Area Low-Level Burial Ground is a shallow landfill disposal facility covering approximately 1,500 acres. The facility is located in two geographically distinct areas, the 200-East and 200-West Areas. Two burial grounds are located in the 200 East Area and one planned and 5 existing burial grounds are located in the 200 West Area. Disposal of LLW occurs in unlined, sloped (approximately 45 degrees) trenches that are about 6 to $7 \mathrm{~m}$ deep and range in length up to approximately $500 \mathrm{~m}$ (DOE 1998a). The trenches are either wide-bottomed (about $8 \mathrm{~m}$ wide) or $\mathrm{V}$-shaped (about $3 \mathrm{~m}$ wide). Based on this standard trench design, capacity of the 200-East and -West facilities is approximately 2 million $\mathrm{m}^{3}$ (DOE 1998a). 240,000 $\mathrm{m}^{3}$ of LLW has been disposed at the burial grounds through 1997, and another 280,000 $\mathrm{m}^{3}$ estimated for disposal from 1998 through 2070 (DOE 1998a). An alternative, deep trench design, would have unlined, sloped trenches about $26 \mathrm{~m}$ deep. If implemented, the disposal facility would have a disposal capacity of approximately 12.8 million $\mathrm{m}^{3}$. The site has an annual average precipitation rate of 6 inches and the underlying aquifer is about $236 \mathrm{ft}$ below the surface (DOE 1998b).

\subsubsection{Nevada Test Site}

The Nevada Test Site (NTS) occupies 1,350 square miles (864,000 acres) of desert valley and

Great Basin mountain terrain in southern Nevada, 65 miles northwest of Las Vegas. Land 
surrounding the site is also predominantly federally owned. The site is bordered to the west, north, and east by the Nellis Air Force Base Bombing and Gunnery Range and the Tonopah Test Range. The NTS has been the primary location for testing the Nation's nuclear explosive devices since 1951. Radioactive waste disposal began at the site in 1961. Other activities on site include environmental restoration efforts throughout the NTS. The site is only accessible to shipments by truck and not rail.

The DOE NTS facility currently serves as a disposal site for LLW generated by DOE and DOE-approved generators. Presently, Areas 3 and 5 are the two operating disposal areas. Area 3 accepts packaged and bulk LLW for disposal in subsidence craters, and Area 5 accepts LLW for disposal in pits and trenches and transuranic and mixed waste for storage (DOE 1996c). Area 3 is located on Yucca Flat and covers an area of approximately 50 acres. Area 5 is located on Frenchman Flat, occupying an area of 732 acres. However, only 92 acres in the southeast corner are currently developed (DOE 1998a). The site experiences an average annual rainfall rate of 7 inches and lies about $787 \mathrm{ft}$ above the water table (DOE 1998b).

The NTS has a total available LLW disposal capacity of 3,150,000 $\mathrm{m}^{3}$ (DOE 1998a). Approximately $670,000 \mathrm{~m}^{3}$ is estimated for disposal, with 190,000 $\mathrm{m}^{3}$ disposed from 1988 to 1997 and an estimated $480,000 \mathrm{~m}^{3}$ projected to be disposed from 1998 to 2070 . Also, given the small developed area within Area 5, the NTS has the capability of significantly increasing its disposal capacity to accommodate larger volumes of LLW.

\subsubsection{Barnwell}

The Barnwell waste management facility is owned by the State of South Carolina and leased to Chem-Nuclear Systems. The 235 acre site located by Barnwell, SC has used 75 percent of the available space for disposal in its 25 years of operation. The method of disposal for LLW at Barnwell is emplacement of LLW containers in concrete vaults. The vaults may be stacked two or three high in engineered trenches. The trenches are back-filled and covered with a multiple layer barrier cap including layers of clay and polyethylene.

Barnwell has an existing available capacity of $91,000 \mathrm{~m}^{3}\left(3.2\right.$ million $\left.\mathrm{ft}^{3}\right)$, but the newly elected governor ran on a platform to close the facility to at least customers outside of the regional compact states (Still 1999).

\subsubsection{Envirocare}

Envirocare of Utah is located in an arid West Desert region in Clive, Utah. The site was originally selected from among 29 candidate sites for disposal of uranium mill tailings from an abandoned uranium mill site. Located approximately 80 miles west of Salt Lake City, the site has an average annual precipitation rate less than 7 inches and an evapotranspiration rate of greater than 60 inches. The site is located 45 miles from the nearest significant population center and is situated above non-potable groundwater. The site has direct truck and rail access.

Envirocare uses an above-ground engineered disposal cell design approved by the U.S. NRC and expected to maintain its integrity for at least 1,000 years. Indigenous low-permeability clays are used to line the bottom of the disposal cell and a 7 foot clay layer is used as part of a multi-layer cell cap. Current available capacity is 10.7 million $\mathrm{m}^{3}$ (380 million $\mathrm{ft}^{3}$ ) (Loveland 1999b). 


\subsubsection{U.S. Ecology}

The U.S. Ecology disposal site in Richland, Washington is located on 100 acres of land within the Hanford Site (between the 200-West and 200-East areas) that are leased to the state of Washington (Hertzler et al. 1994). The site has been in operation since 1965 and has an available capacity of approximately 1.3 million $\mathrm{m}^{3}\left(45\right.$ million $\left.\mathrm{ft}^{3}\right)$. Because this site can only accept wastes from states in the Northwest LLW Compact (Alaska, Idaho, Montana, Oregon, Utah, Washington, and Wyoming) (Ault 1999), it was dropped from further consideration.

\subsubsection{Waste Control Specialists}

The Waste Control Specialists (WCS) site is located near the Texas-New Mexico border in Andrews County Texas, approximately 30 miles east of the Waste Isolation Pilot Plant. The 1,338 acre treatment, storage, and disposal facility is buffered within a 16,073 acre site owned by WCS. The nearest town (Eunice, N.M., pop. 2,700) is six miles from the site. No surface water exists on the site, and the water table lies about $800 \mathrm{ft}$. down through red clay where the water is non-potable. Annual averages for rainfall and evapotranspiration in the region are 11 and greater than 100 inches, respectively.

WCS is currently permitted for treatment and storage of LLW and mixed waste and is attempting to obtain a LLW disposal permit from the state of Texas which so far has been denied. WCS has a disposal permit for RCRA and TSCA wastes for which it has a disposal capacity of 8.4 million $\mathrm{m}^{3}$ (297 million $\left.\mathrm{ft}^{3}\right)$. Additional capacity for LLW disposal could easily be developed. WCS is retained for further consideration, but unless it obtains a LLW disposal permit from the state of Texas, WCS will not be able to accept the DU for disposal. Texas, which is an Agreement State, has so far denied the WCS permit application because the facility is not located on State or federal land, which is required by 10 CFR 61.59 (see Section 3.3.2.2). This regulation may be a significant hurdle to WCS obtaining a disposal permit.

\subsubsection{Waste Acceptance Criteria}

The waste acceptance criteria (WAC) for all LLW disposal sites considered are very much like one another because NRC-licensed facilities and DOE disposal facilities must adhere to similar requirements. NRC-licensed disposal facilities must comply with the waste characteristics listed in 10 CFR 61.56 as summarized in Table 3.4 (see Section 3.3.2.2) and DOE disposal facilities must adhere to the characteristics listed in DOE M 435.1-1 as summarized in Table 3.7 (see Section 3.3.3). The primary objective is to ensure the emplacement of waste forms that do not endanger workers at the facility, the general public, and the present and future integrity of the facility. Since stable waste forms are desired, reactive materials are excluded. In general, all WAC exclude bulk liquids, water reactive materials, explosives, pyrophoric materials, materials capable of generating gases that would result in over pressurization of disposal containers, and materials that are capable of generating toxic gases, vapors, or fumes. The relevant portion of the WAC for each site that pertains to the chemical and physical properties of the waste forms is reproduced in Appendix C.

As identified in Section 3.2, the depleted uranium waste form is considered to be source material. The depleted uranium forms of bulk $\mathrm{UO}_{2}, \mathrm{U}_{3} \mathrm{O}_{8}$, and uranium metal have total uranium activities of 355,341 , and $402 \mathrm{nCi} / \mathrm{g}$, respectively, corresponding to depleted uranium with an enrichment of $0.25 \%$ U-235 (LLNL 1997a). 
With respect to radioactive material limits, NTS and Barnwell do not have explicit limits on uranium concentrations, activities, or amounts in the WAC, but NTS does place a limit of $544 \mathrm{~kg}$ per 55-gallon drum (Section 3.26 of the NTS WAC) which exceeds the $600+\mathrm{kg} /$ drum assumptions used for the $\mathrm{U}_{3} \mathrm{O}_{8}$ packaging in the PEIS. Also, the NTS WAC specifies shipment in either standard waste boxes or 55-gallon drums. The PEIS assumed shipment of the $\mathrm{UO}_{2}$ in 30 -gallon drums. Either a package redesign or exemption would be required for disposal of the oxides at the NTS using the PEIS packaging assumptions.

The radiological concentration of $\mathrm{U}-238$ in either the $\mathrm{UO}_{2}\left(2.7 \mathrm{Ci} / \mathrm{m}^{3}\right)$ or bulk metal $\left(6.4 \mathrm{Ci} / \mathrm{m}^{3}\right)$ wasteforms exceeds the limits identified for Category 3 wastes in the Hanford WAC for U-238 (1.2 Ci/m³ $\mathrm{m}^{3}$ Appendix A of the Hanford WAC). U-234 and U-235 concentrations are within the Category 3 limits. At Hanford, Category 3 identifies waste with a specific activity high enough to warrant special packaging and stabilization requirements. In addition, the Hanford WAC specify that waste "shall not exceed Category 3, except with an analysis coordinated by the [Waste Management Federal Services of Hanford, Inc. (WMH)] acceptance organization demonstrating that the [low-level burial grounds] Performance Assessment conditions are met" (HNF-EP-0063, Rev. 5, Sec. 3.4.2). Notwithstanding, discussions with Hanford site personnel indicated that this does not necessarily preclude disposal of these DU waste forms at Hanford. On the contrary, site personnel seemed confident that proper packaging and/or stabilization would prepare either $\mathrm{UO}_{2}$ or uranium metal in a manner that could be demonstrated to meet the burial ground performance assessment conditions (Blanchard 1999). For example, such a solution may include stabilization in concrete. Another alternative may be disposal in high integrity containers (HICs). HICs are designed to maintain their integrity for over 300 years (WHC 1996) and are used often at Hanford. One example of a HIC that Hanford maintains in its inventory is a vault type concrete HIC (10.5 ft long by $7 \mathrm{ft}$ wide by $9.5 \mathrm{ft}$ high).

Depleted $\mathrm{U}_{3} \mathrm{O}_{8}$ would be classified as a Category 3 waste according to the Hanford WAC and, as stated in the WAC, would be required to 1) be disposed in a suitable HIC, or 2) be stabilized in concrete or another stabilization agent, or 3) meet requirements as an inherently stable waste that meets the stability requirements of 10 CFR 61.56 and the NRC Technical Position Paper on Waste Form. In addition, the DU uranium concentrations in all forms exceed the total uranium concentration limit for mobile radionuclides in Appendix A of the WAC $\left(1.4 \times 10^{-5} \mathrm{Ci} / \mathrm{m}^{3}\right)$. Such an exceedance requires stabilization, usually in a HIC. Thus, disposal of DU at Hanford would require detailed analysis by site personnel to determine the proper treatment and packaging for any of the oxide or metal wasteforms under consideration.

For radioactive activity limits, the Envirocare WAC references its Radioactive Material License from the Utah Department of Environmental Quality (License Number UT 2300249, Amendment \#4). The average concentration per container on receipt for depleted uranium is limited to $370 \mathrm{nCi} / \mathrm{g}$ which is higher and lower than those estimated above for the oxides and the metal, respectively. Thus, Envirocare's current Radioactive Material License appears to exclude the pure depleted uranium metal form from disposal. However, future amendments to the radioactive material license could increase the concentration limit as they have in the past (Loveland 1999a). Stabilization of the metal by mixing with or encapsulating in another material could also be a solution. 
The WAC for WCS explicitly includes uranium source material as acceptable, but does not have the required disposal license as previously discussed in Section 4.4.6. If interim storage limits are used, the WAC limits on the amount of uranium on site $(20,000 \mathrm{Ci}$ for natural U, U-235, or U238) would only account for approximately one-tenth of the DU inventory.

Disposal of depleted uranium in the $\mathrm{UO}_{2}$ and $\mathrm{U}_{3} \mathrm{O}_{8}$ oxide forms would be acceptable under current WAC at the NTS, Envirocare, and Barnwell LLW disposal sites. Disposal of $\mathrm{UO}_{2}$ at Hanford may require repackaging or stabilization and a performance assessment by site personnel while $\mathrm{U}_{3} \mathrm{O}_{8}$ might require additional packaging. As discussed in Section 2.5, the reactivity of the other candidate waste forms $\left(\mathrm{UF}_{6}, \mathrm{UO}_{2} \mathrm{~F}_{2}\right.$, and $\left.\mathrm{UF}_{4}\right)$ make these options unsuitable under current WAC. Disposal of uranium as metal is not explicitly prohibited by federal, state, or DOE regulations (see Section 3). Initial discussions with disposal site personnel indicated that acceptance of uranium as metal would not be a problem so long as the waste form complies with existing WAC, which, as discussed in Section 2.5, would have to be critically examined by site personnel. Disposal of uranium metal at Hanford may require repackaging or stabilization and a performance assessment by site personnel. The NTS has disposed of uranium metal in the past from Army sources (Hertzler et al. 1994), but it was encapsulated in concrete (DOE 1995).

\subsubsection{Available Capacities}

Table 4.1 lists the available disposal capacities at the sites under consideration. Included in the table are the required disposal volumes for the DU under consideration for each waste form. A factor of 15 to 16 is the difference between the smallest and largest volumes estimated. The largest disposal volume, approximately 14.5 million $\mathrm{ft}^{3}$, is required for grouted $\mathrm{U}_{3} \mathrm{O}_{8}$, while the smallest disposal volume, approximately $911,000 \mathrm{ft}^{3}$, is required for uranium metal if the metal is packaged in standard boxes without void spaces and not encapsulated in concrete or placed in a more robust package design to delay eventual reaction with moisture.

Four facilities, Hanford, NTS, Envirocare, and WCS, have enough projected excess capacity to comfortably handle the projected volumes of DU disposal volumes. The lowest capacity of this group, 52.3 million $\mathrm{ft}^{3}$ at Hanford, is a factor of 3 to 4 times larger than the largest possible disposal volume required (14.5 million $\mathrm{ft}^{3}$ for grouted $\mathrm{U}_{3} \mathrm{O}_{8}$ ). A proposed alternative to go to a deep trench design at Hanford as discussed in Section 4.4.1 would expand Hanford's available capacity further by more than a factor of five. Envirocare has the largest available capacity, 380 million $\mathrm{ft}^{3}$, that is 26 times the capacity required to dispose of the largest potential volume of DU as grouted $\mathrm{U}_{3} \mathrm{O}_{8}$.

Barnwell's existing capacity of 3.2 million $\mathrm{ft}^{3}$ is insufficient to meet the needs for disposal as grouted $\mathrm{UO}_{2}$ or either ungrouted or grouted $\mathrm{U}_{3} \mathrm{O}_{8}$. Disposal as ungrouted $\mathrm{UO}_{2}$ would require twothirds or more of its limited available capacity while disposal as uranium metal would require approximately one-third of its available capacity.

\subsubsection{Disposal Costs}

Current disposal costs are estimated to range from approximately $\$ 7$ (Hanford) to more than $\$ 325$ per cubic foot (Barnwell). Table 4.1 summarizes these rates and, using these rates, presents estimated costs for disposal of the entire inventory of each different waste form considered. If disposal in a HIC at Hanford is required for the selected DU wasteform, disposal costs would be 
approximately $\$ 31$ per cubic foot based on a disposal volume of 100,000 to 200,000 $\mathrm{ft}^{3}$ (Blanchard 1999), an increase of about a factor of 4 . Future increases in disposal costs were not considered. Material conversion, packaging, and transportation are not included. Also not included are regulatory compliance and wasteform facility construction and operation costs. The rates are subject to some variability depending in part on the annual volume of waste to be disposed. The rates for Envirocare are based on a contract with DOE through the Ohio Field Office that is available to all DOE facilities.

Hanford and NTS have the lowest estimated costs, ranging from approximately \$6.5 million for disposal of uranium as bulk metal to about $\$ 110$ million for disposal of grouted $\mathrm{U}_{3} \mathrm{O}_{8}$. Highest costs were at Barnwell. The cost for disposal of ungrouted $\mathrm{UO}_{2}$ was estimated to be approximately $\$ 700$ million as shown in Table 4.1.

Currently, there are no underground mined disposal facilities that can readily accept depleted uranium materials for disposal. It is possible that some former or currently operating uranium mine can be used for this purpose. This study has not made any special effort to identify such mines. It is also possible that a new mined underground disposal facility could be constructed for the purpose of disposing the depleted uranium contained in DOE's depleted UF $_{6}$ inventory. In the PEIS, it was assumed that such a facility would be constructed. Impacts associated with the construction as well as the operation of such a facility were analyzed and are discussed in Sections 5 and 6.

Barnwell is the only LLW disposal facility considered in this study that employs disposal in vaults. The PEIS also considered and analyzed disposal in vaults. Because of Barnwell's limited capacity, the impacts of constructing as well as operating such a facility were also considered in Sections 5 and 6.

The facility construction costs for vaults and an underground mine were estimated for disposal of $\mathrm{U}_{3} \mathrm{O}_{8}$ and $\mathrm{UO}_{2}$ in ungrouted and grouted waste forms (LLNL 1997b). These costs were based on disposal of the 560,000 metric tons of DOE-generated depleted $\mathrm{UF}_{6}$, and do not include the additional costs associated with the larger facilities required to contain the additional volume generated by USEC. Site preparation and facility construction costs ranged from approximately $\$ 28$ million for disposal of ungrouted $\mathrm{UO}_{2}$ in a vault facility to approximately $\$ 580$ million for disposal of grouted $\mathrm{U}_{3} \mathrm{O}_{8}$ in an underground mined cavity. Because complete construction of an underground mine facility was assumed, lower costs might be achieved if an existing mine facility were modified for the purpose of DU disposal. 


\section{HUMAN HEALTH AND SAFETY}

This section summarizes the human health and safety impacts estimated for the disposal of depleted uranium (Chapters 5 and 6 and Appendix I in DOE 1999). Potential disposal impacts were evaluated for two different uranium oxides, $\mathrm{U}_{3} \mathrm{O}_{8}$ and $\mathrm{UO}_{2}$. Both oxide forms have very low solubility in water and are relatively stable over a wide range of environmental conditions (see Section 2). For each form, several disposal options were considered, including disposal in shallow earthen structures, belowground vaults, and an underground mine. Although the disposal of depleted uranium metal was not analyzed in detail in the PEIS, a qualitative assessment of impacts for disposal of DU as metal is given in each of the following sections when possible because of recent inquiries into the matter.

Two physical waste forms were considered in the PEIS analysis, ungrouted and grouted uranium oxide. Ungrouted waste refers to $\mathrm{U}_{3} \mathrm{O}_{8}$ or $\mathrm{UO}_{2}$ in the powder or pellet form produced during the conversion process. This bulk material would be disposed of in either 55-gal (208-L) drums for $\mathrm{U}_{3} \mathrm{O}_{8}$ or 30-gal (110-L) drums for $\mathrm{UO}_{2}$. Grouted waste refers to the solid material obtained by mixing the uranium oxide with cement and repackaging it in drums. Grouting is intended to increase structural strength and stability of the waste and to reduce the solubility of the waste in water. However, because cement is added to the uranium oxide, grouting would increase the total volume requiring disposal. Grouting of waste was assumed to occur at the disposal facility.

The potential impacts from disposal were estimated for two phases: (1) the operational phase, which is the period during which drums would be actively placed into disposal units, and (2) the post-closure phase, which extends up to 1,000 years in the future after the assumed failure of the disposal units. Minimal construction impacts for disposal in shallow earthen structures are expected because the existing LLW disposal sites, which are primarily shallow earthen structures, have ample disposal capacity for the DU (Section 4.4.8). A brief summary of the impacts related to construction of vault or mine disposal facilities as evaluated in the PEIS (Appendix I in DOE 1999) are briefly discussed in this summary (Section 5.1).

No matter how well designed, all disposal facilities would be expected to release material to the environment (or "fail") eventually. In general, shallow earthen structures would be expected to contain waste material for at least several hundred years before failure, and vaults and mines would be expected to last even longer. For purposes of the analysis, failure of all three types of disposal facilities was assumed to occur at the end of a period of institutional control, 100 years after closure. Because of the infiltration of water, uranium could ultimately migrate through the soil and eventually contaminate the groundwater. The potential impacts during the post-closure phase would result from using contaminated groundwater that could affect members of the general public.

The estimated impacts associated with the disposal alternative are subject to a great deal of uncertainty - especially during the post-closure phase. In general, the degree of uncertainty associated with potential post-closure impacts is greater than that for the other impacts considered. The analysis of post-closure impacts considered an extremely long period of time and was based on predicting the behavior of the uranium material after disposal as it interacts with soil and water in a complex and changing environment. Consequently, the estimated impacts are very dependent on 
the assessment assumptions. Key assumptions included such factors as soil characteristics, water infiltration rates, depth to the underlying groundwater table, chemistry of different uranium compounds in the soil, and locations of future human receptors. These factors could vary widely, depending on site-specific conditions. In response, the assumptions used in the PEIS (DOE 1999) were generally selected in a manner intended to produce conservative estimates of impacts, that is, the assumptions tend to overestimate the potential impacts.

\subsection{Construction Impacts for Vault or Underground Mine Disposal}

The physical hazards for construction of a disposal facility would be greatest for an underground mine for disposal of grouted $\mathrm{U}_{3} \mathrm{O}_{8}$ with approximately 1 fatality, about twice the comparable risk for any other option. The lowest fatality risk, approximately 0.1 , estimated was for disposal of $\mathrm{UO}_{2}$ in vaults. Estimated worker injuries during construction ranged from approximately 40 (vault for disposal of ungrouted $\mathrm{UO}_{2}$ ) to 300 (mine for disposal of grouted $\mathrm{U}_{3} \mathrm{O}_{8}$ ).

\subsection{Normal Facility Operational Phase}

\subsubsection{Radiological Impacts}

Radiological impacts during normal operations of the facility were estimated for involved workers, noninvolved workers, and members of the general public.

\subsubsection{Workers}

Table 5.1 summarizes impacts to involved workers. External radiation resulting from the handling of uranium materials would be the major source of exposure for involved workers, primarily during the placement of drums of uranium oxide into the disposal areas or during the grouting of waste. The impacts to involved workers would be similar for the disposal of $\mathrm{U}_{3} \mathrm{O}_{8}$ and $\mathrm{UO}_{2}$, with estimated collective worker doses approximately twice as high for the disposal of grouted waste compared to ungrouted waste because of the additional worker activities required by grouting.

Variations in exposures for the three disposal types considered (shallow earthen structures, vaults, or mine) would be caused by different practices for different technologies. Disposal in a mine would require transport of waste containers from the ground surface to the underground cavities, whereas disposal in shallow earthen structures and vaults would require filling and capping efforts to cover the waste containers with dirt, cement, and/or other engineering materials. In general, average radiation exposure of involved workers would be less than $630 \mathrm{mrem} / \mathrm{yr}$.

Within a given disposal type, worker exposure resulting from disposal of metal is expected to be approximately the same as for disposal as $\mathrm{UO}_{2}$. The primary difference, as seen when comparing the ungrouted $\mathrm{U}_{3} \mathrm{O}_{8}$ and $\mathrm{UO}_{2}$ options, is a result of the number of waste packages that require handling. If the packaging assumptions in the PEIS (DOE 1999) for storage of DU as metal are used, the worker exposure could be approximately $40 \%$ greater for the metal option versus the ungrouted $\mathrm{UO}_{2}$ option (approximately 797,000 billet boxes versus approximately 556,000 30 gallon drums) or about $5 \%$ less than the grouted $\mathrm{UO}_{2}$ option (836,000 30 gallon drums). However, these 
impacts for metal might be slightly less compared to the oxide because more self-shielding is expected for the metal.

No variation in exposure is expected when comparing involved worker doses at facilities in dry and wet environmental settings. At all facilities, radiation exposure of workers would be maintained in accordance with ALARA practices.

Exposure of noninvolved workers to both airborne and waterborne pathways would result from releases of uranium compounds from the grouting facility. Exposure was small; collective doses for noninvolved workers were estimated to range between approximately $2 \times 10^{-5}$ and $2 \times 10^{-4}$ person-rem/yr, with MEI doses less than $0.02 \mathrm{mrem} / \mathrm{yr}$.

\subsubsection{General Public}

Exposure of the general public to both airborne and waterborne pathways would result from releases of uranium compounds from the grouting facility. Estimated collective radiation doses to members of the general public ranged from approximately 0.002 to 0.01 person-rem/yr. For all options considered, MEI doses were less than $0.05 \mathrm{mrem} / \mathrm{yr}$ and tended to be similar between dry and wet environmental settings.

\subsubsection{Chemical Impacts}

Potential chemical impacts to human health from normal operations at the disposal facilities would result primarily from exposure to the insoluble uranium compounds, $\mathrm{UO}_{2}$ and $\mathrm{U}_{3} \mathrm{O}_{8}$. Risks from normal operations were quantified on the basis of calculated hazard indices.

Impacts to involved workers from exposure to chemicals during normal operations would not be expected. The workplace would be monitored to ensure that airborne chemical concentrations were within applicable health standards that are protective of human health and safety. If planned work activities were likely to expose involved workers to chemicals, they would be provided with appropriate protective equipment as necessary.

Chemical impacts during the operational phase of the disposal facilities were calculated for noninvolved workers and the general public. Exposures of noninvolved workers and the general public to low levels of airborne emissions could occur from mixing uranium with cement and other grouting materials in the wasteform facility. Three disposal types (shallow earthen structures, vaults, and mines) were considered for $\mathrm{U}_{3} \mathrm{O}_{8}$ and $\mathrm{UO}_{2}$ as both grouted and ungrouted wastes in generic dry and wet environmental settings. The hazard indices for all disposal options were four orders of magnitude less than 1, the level for which potential adverse health effects could occur from normal operations. No impacts would occur for disposal of ungrouted $\mathrm{U}_{3} \mathrm{O}_{8}$ or $\mathrm{UO}_{2}$ because airborne emissions would not be expected (LLNL 1997a). Airborne emissions would also not be expected for disposal of uranium metal, unless the metal billets are repackaged and/or grouted at the disposal facility, in which case the releases and impacts would be expected to be comparable to the grouted $\mathrm{UO}_{2}$ case. 


\subsection{Operational Phase Facility Accidents}

\subsubsection{Physical Hazards}

The risk of on-the-job fatalities and injuries to all disposal facility workers was calculated using industry-specific statistics from the Bureau of Labor Statistics, as reported by the National Safety Council (1995). Manufacturing annual fatality and injury rates were used for the operational component of the disposal facility activities.

Estimated fatalities range from 0.06 to 0.19 , and injury incidences range from 73 to 250 (see Table 5.2). The options are fairly comparable with respect to predicted fatalities and injuries due to physical trauma. In general, the ungrouted $\mathrm{UO}_{2}$ option had the minimum number of impacts because of the smaller number of packages that required handling. Thus, disposal of uranium metal is expected to have slightly higher impacts than the ungrouted $\mathrm{UO}_{2}$ option for the same reason.

\subsubsection{Accidental Release of Depleted Uranium}

A range of accidents covering the spectrum of high-frequency/low-consequence accidents to low-frequency/high-consequence accidents was analyzed for the oxide disposal options. Table 5.3 provides a description of the accidents considered. The impacts presented here were obtained by assuming that the accidents would occur. The probability of occurrence for each accident is indicated by the frequency category to which it belongs. For example, accidents in the extremely unlikely category have a probability of occurrence between 1 in 10,000 and 1 in 1 million in any 1 year.

\subsubsection{Radiological Impacts}

The radiological doses to various receptors for the accidents that give the highest dose from each frequency category are listed in Table 5.4. The LCF risks for these accidents are given in Table 5.4. The doses and the risks are presented as ranges (maximum and minimum) because two different meteorological conditions (F stability and D stability) were evaluated for each disposal option. The following conclusions may be drawn from the radiological health impact results:

- No cancer fatalities would be predicted from any of the accidents.

- Except for the impacts to a noninvolved worker MEI from an earthquake accident, the maximum radiological dose to noninvolved worker and general public MEIs (assuming an accident occurred) would be $1.1 \mathrm{rem}$. This dose is less than the 25 -rem dose recommended for assessing the adequacy of protection of public health and safety from potential accidents by the U.S. Nuclear Regulatory Commission (NRC 1994b).

- For an earthquake accident, the potential dose to the noninvolved worker MEI would range from 0.22 to $140 \mathrm{rem}$, depending on the option implemented for uranium disposal. The NRC recommendations are not directly applicable to workers but are used in this instance as a guideline to indicate potential for health effects. A dose of 140 rem could result in temporary adverse health effects to the MEI worker. 
- The overall radiological risk to worker and general public MEI receptors (estimated by multiplying the risk per occurrence [Table 5.5] by the annual probability of occurrence by the number of years of operations) would be less than 1 for all of the disposal accidents.

\subsubsection{Chemical Impacts}

The accidents assessed in this section are listed in Table 5.3. The results of the accident consequence modeling in terms of chemical impacts are presented in Table 5.6 as the number of people with the potential for adverse effects. Only one accident, an earthquake involving grouted $\mathrm{U}_{3} \mathrm{O}_{8}$, would have the potential for irreversible adverse effects. In this latter case, only one individual in the MEI location might experience irreversible adverse effects. For potential adverse effects, Table 5.6 presents the results for the accident within each frequency category that would affect the largest number of people (total of noninvolved workers and off-site population) (Policastro et al. 1997). The number of workers and members of the off-site public represent the impacts if the associated accident was assumed to occur. These impacts may be summarized as follows:

- If the accidents identified in Table 5.3 did occur, the number of persons in the off-site population with potential for adverse effects and irreversible adverse effects would range from 0 to 1 (MEI), the maximum corresponding to an earthquake accident. The number of workers with potential for adverse effects and irreversible adverse effects would range from 0 to 1 , the maximum also corresponding to the earthquake accident.

- The largest impacts would be caused by an earthquake in the product receiving and cement mixing areas. Accidents involving stack emissions would have very small impacts compared with accidents involving releases at ground level due to the large dilution (and lower source terms) involved with the stack emissions.

- For the earthquake accident, the noninvolved worker and the public MEIs could experience potential for both adverse effects and irreversible adverse effects. For all other accidents, the worker and general public MEIs would experience neither potential adverse effects nor potential irreversible adverse effects.

- The maximum risk was computed as the product of the consequence (number of people) times the frequency of occurrence (per year) times the number of years of operations (26 years). The results indicated that the maximum risk values would be less than 1 for all accidents. These risk values are conservative because the numbers of people affected were based on assuming (1) meteorological conditions that would result in the maximum reasonably foreseeable plume size (i.e., F stability and $1 \mathrm{~m} / \mathrm{s}$ wind speed) and (2) wind in the direction that would lead to maximum numbers of individuals exposed for workers or for the general population.

To aid in the interpretation of accident analysis results, the number of fatalities potentially associated with the estimated potential irreversible adverse effects was estimated. The bounding case accidents shown in Table 5.3 would involve releases of uranium oxide and potential exposure to uranium compounds. If the accident occurred, exposures are estimated to result in death for $1 \%$ or fewer of the persons experiencing irreversible adverse effects (Policastro et al. 1997). Thus, for noninvolved workers and members of the general public experiencing a range of 0 to 1 irreversible adverse effects, 0 deaths would be expected. 


\subsection{Post-Closure Phase Impacts}

This section provides a summary of the potential environmental impacts associated with the post-closure phase of the disposal options. The post-closure phase considers the potential environmental impacts that could occur in the future, well beyond the time that any engineered disposal facility would be expected to function as designed. Post-closure impacts are evaluated because, no matter how well designed, all disposal facilities would be expected to release material to the environment eventually, a condition referred to as "failure."

Disposal facility failure would generally occur hundreds to thousands of years in the future (assuming no sustained effort to maintain the facility). This failure would be caused by natural degradation of the disposal structures over time, primarily from physical processes such as the intrusion of water. Following failure, the release of uranium from the facility would occur very slowly as water moved through the disposed material. This water would carry dissolved uranium through the soil under the facility, eventually contaminating the groundwater. This process could continue for thousands to millions of years because of the large amount of uranium in the disposal facility and low solubility of that uranium.

In general, shallow earthen structures would be expected to contain the waste material for a period of at least several hundred years before failure. Vaults and a mine would be expected to last even longer, from many hundreds to thousands of years before failure. However, the exact time that a disposal facility would be expected to fail is extremely difficult to predict and would depend on the detailed facility design and site-specific conditions. Because of this difficulty, failure was assumed to occur at the end of a period of institutional control, 100 years after closure. The postclosure impacts were evaluated at 1,000 years after failure for all three disposal facility options.

The estimated impacts associated with the post-closure phase are subject to a great deal of uncertainty because the assessment considers an extremely long period of time and depends on predicting the behavior of the waste material as it interacts with soil and water in a complex and changing environment. Consequently, the estimated impacts are very dependent on the assessment assumptions. Key assumptions include such factors as soil characteristics, water infiltration rates, depth to the underlying groundwater table, chemistry of different uranium compounds, and the locations of future human receptors. These factors can vary widely depending on site-specific conditions. Because of these uncertainties, the assumptions were generally selected in a manner intended to produce conservative estimates of impact, that is, the assumptions tend to overestimate the expected impact. Changes in key disposal assumptions could yield significantly different estimates of impact.

The potential effects on human health in the future were estimated by assuming that a person lived at the edge of the disposal site and used groundwater for drinking, irrigating plant foods and fodder, and feeding livestock. In addition, it was assumed that, at some point in the future, the engineered barriers of the disposal facility would fail, allowing uranium to be released into the soil. To address uncertainties related to the disposal site properties, the facility was assumed to be located at either a dry setting (typical of the western United States) or a wet setting (typical of the eastern United States). In addition, it was assumed that the site had soil properties that permitted uranium 
to either move rapidly through the soil (mobile situation) or slowly through the soil (immobile situation). The potential radiation doses from future groundwater contamination were based on the estimated groundwater concentrations discussed in Section 6.2.3.

In a dry setting, the groundwater analysis indicated that measurable groundwater contamination would not occur until more than 1,000 years after failure of the disposal facility, even if the uranium were assumed to move rapidly through the soil. Groundwater contamination would not occur within 1,000 years because of the small amount of rainfall typical of a dry setting and the resulting small amount of water that would infiltrate the disposal facility. In addition, a large distance to the groundwater table would be expected in a dry environment. Therefore, no radiation or chemical exposures of members of the general public from contaminated groundwater would be expected within 1,000 years following failure of a disposal facility in a dry environment.

In a typical wet setting, groundwater contamination was estimated to occur within 1,000 years after failure of the disposal facility for shallow earthen structures, vaults, and mines. The maximum radiation dose to an individual assumed to use contaminated groundwater was estimated to be about $120 \mathrm{mrem} / \mathrm{yr}$ if the soil properties were such that the uranium moved rapidly through the soil (Table 5.7). If the depleted uranium was classified as LLW, the radiation doses from using contaminated groundwater would exceed the dose limit of $25 \mathrm{mrem} / \mathrm{yr}$ specified in 10 CFR Part 61 and DOE Order 5820.2A. In addition, the groundwater concentrations would be great enough to cause potential adverse effects from chemical exposures. The chemical hazard indices were calculated to range up to 10 , indicating the potential for chemically induced adverse effects. However, impacts from using contaminated groundwater could be reduced or eliminated by treating the water or by using an alternative source of water.

In addition to possible exposures resulting from the use of contaminated groundwater, health impacts could result if a person inadvertently intruded or if the cover material (i.e., soil) above the disposal facility eroded away. The radiation dose was estimated to be as high as $10 \mathrm{rem} / \mathrm{yr}$ for a hypothetical future resident living on the disposal site in such a case. Chemical health effects from uranium exposure could also be possible. Erosion of the cover material would probably not occur until several thousands of years after closure of a shallow earthen structure or vault disposal facility and would probably not occur at all for a mine disposal facility. If cover materials were to erode away, radiation exposures could be easily mitigated by adding new cover material. 


\section{OTHER ENVIRONMENTAL IMPACTS}

The operational phase of a depleted uranium disposal facility would require water resources and generate air and water emissions. The primary impact to the environment during the post-closure phase of a disposal facility would be to the groundwater following failure of containment. The extent of these emissions and their impact on ecological resources is summarized in this section.

\subsection{Air Quality}

\subsubsection{Construction Impacts for Vault or Underground Mine Disposal}

Estimated air concentrations for criteria pollutants for construction of the wasteform facility and vaults for disposal were estimated to be lower than those estimated for facility operations. Thus, as discussed in the following section, all emissions were estimated to be within standards and guidelines.

\subsubsection{Operational Phase}

Air quality impacts from operation of a disposal facility would depend on the actual facility location. Based on analyses for a generic setting of typical size for this type of facility, the concentrations of criteria pollutants (carbon monoxide (CO), hydrocarbons (HC), nitrogen oxides $\left(\mathrm{NO}_{\mathrm{x}}\right)$, sulfur oxides $\left(\mathrm{SO}_{\mathrm{x}}\right)$, and particulate matter $\left(\mathrm{PM}_{10}\right)$, with a mean diameter of $10 \mathrm{~m}$ or less) were estimated to be within applicable standards. The criteria pollutant with the highest potential emissions would be $\mathrm{NO}_{\mathrm{x}}$; concentrations of $\mathrm{NO}_{\mathrm{x}}$ were estimated to be within standards and guidelines.

For disposal options that include grouting the waste, operation of a waste form facility would emit about $0.6 \mathrm{lb} / \mathrm{yr}(0.3 \mathrm{~kg} / \mathrm{yr})$ or $1.1 \mathrm{lb} / \mathrm{yr}(0.5 \mathrm{~kg} / \mathrm{yr})$ of uranium for grouted $\mathrm{U}_{3} \mathrm{O}_{8}$ and grouted $\mathrm{UO}_{2}$ options, respectively. NESHAPs, 40 CFR Part 61, Subpart H (see the discussion in Section 3.3.4), limits emissions of radionuclides other than radon from DOE facilities to less than the amount that would cause any member of the public to receive in any year an effective dose equivalent of 10 mrem/yr. Potential health impacts of these emissions were evaluated in Section 5.2, with MEI doses less than $0.02 \mathrm{mrem} / \mathrm{yr}$, well within the $10 \mathrm{mrem} / \mathrm{yr}$ limit.

The impacts of uranium oxides emitted during operation of the wasteform facility for grouted disposal options are shown in Table 6.1. Comparing the ranges of concentrations for the wet and dry settings indicates that the uranium emissions from the central point source would produce a slightly wider range of impacts for the dry setting than for the wet setting.

No quantitative estimate was made of the impacts on the ozone conditions. Ozone formation is a regional issue that would be affected by emissions for the entire area around a proposed disposal site. The pollutants most relevant to ozone formation that would result from the disposal of depleted uranium oxide are $\mathrm{HC}$ and $\mathrm{NO}_{\mathrm{x}}$. However, the small additional contributions to the regional totals would be unlikely to alter the ozone attainment status of the selected region. 


\subsection{Water}

\subsubsection{Construction Impacts for Vault or Underground Mine Disposal}

Estimated water requirements ranged from 0.2 to 1.1 million gallons per year for construction of a waste form facility for ungrouted $\mathrm{UO}_{2}$ and grouted $\mathrm{U}_{3} \mathrm{O}_{8}$, respectively. Water requirement estimates for construction of the disposal facility ranged from 0.2 to 1.7 million gallons per year for vaults for ungrouted $\mathrm{UO}_{2}$ and grouted $\mathrm{U}_{3} \mathrm{O}_{8}$, respectively. Intermediate values were estimated for mine construction. Wastewater requirements ranged from 0.005 to 0.2 million gallons per year for construction of vaults for ungrouted $\mathrm{UO}_{2}$ disposal or construction of a mine for grouted $\mathrm{U}_{3} \mathrm{O}_{8}$ (or grouted $\mathrm{UO}_{2}$ ), respectively.

\subsubsection{Operational Phase}

Table 6.2 summarizes the water resource requirements for operation of the wasteform facility, shallow earthen structure disposal facility, vault disposal facility, and mine disposal facility, respectively. Examination of these data indicates that the ranking of facilities (largest to smallest) on the basis of resource requirements would be as follows: mine, vault, shallow earthen structure, and wasteform facility. For each facility, a secondary ranking indicates that the resource requirements would be consistently larger for disposal of $\mathrm{U}_{3} \mathrm{O}_{8}$, and grouted forms would require more resources than ungrouted.

Because the disposal analysis is based on a generic site without a specified location and detailed description, impacts could not be assessed on a site-specific basis; however, the impacts to surface water and groundwater would follow the same ranking as that for resource needs. For example, operation of a mine disposal facility for $\mathrm{U}_{3} \mathrm{O}_{8}$ in a grouted form would produce the greatest impacts to the environment; fewest impacts would result from operation of the shallow earthen structure for disposal of grouted or ungrouted $\mathrm{UO}_{2}$.

If the disposal facility were located near a river having a minimum flow that was large compared with annual water use and wastewater discharge, impacts to surface water and groundwater would be negligible. Negligible impacts would occur because a large river could provide sufficient resource buffering to mitigate the effects produced by operation of the facility.

On the other hand, if the minimum flow in the river were small relative to the resource requirements, impacts would be larger. For example, if the minimum flow in the river was 500 gpm, the net annual water withdrawal for operation of the wasteform facility for disposing of grouted $\mathrm{U}_{3} \mathrm{O}_{8}$ would be about $10 \%$ of the flow. The impact of this relative withdrawal could produce moderate impacts to existing floodplains.

\subsubsection{Post-Closure Phase}

For disposal, impacts on groundwater in the distant future would depend on the location of the facility. If the disposal facility were located in a dry environment typical of the western United States, groundwater impacts in the form of elevated uranium concentrations (i.e., concentrations greater than the proposed drinking water standard of $20 \mathrm{~g} / \mathrm{L}$ ) would not occur for at least 1,000 years after failure of the facility. However, for a disposal facility in a wet environment, typical of the 
eastern United States, groundwater quality could be affected by contamination migrating from the disposal facility within 1,000 years after failure of the engineered barriers.

For purposes of analysis, if no sustained effort were made to maintain a disposal facility, failure of the facility (defined as the release of uranium material to the surrounding soil) was assumed to occur 100 years after closure. This failure could be caused by natural degradation of the disposal structures over time, primarily from physical processes such as the intrusion of water. With good engineering, disposal facilities would actually be unlikely to fail for several hundred years or more.

Following failure, the release of uranium from the facility would occur very slowly as water moved through the disposed material. The amount of groundwater contamination, as well as the length of time it would take for the groundwater to become contaminated, would depend on the integrity of the drums and the engineered barriers, whether or not the waste was grouted, and sitespecific properties of the soil surrounding the disposal facility. Without more precise information concerning the expected duration of effectiveness for the containers and engineered barriers in the specific disposal facility environment, as well as site-specific soil and hydrological properties, the potential groundwater concentrations are subject to a large degree of uncertainty.

For a generic wet setting, if the soil properties were such that the uranium moved relatively rapidly through the soil, the uranium concentration in the groundwater beneath the facility 1,000 years after facility failure was estimated to range from about 280 to $510 \mathrm{pCi} / \mathrm{L}$ (1,100 to 2,000 g/L) for disposal of $\mathrm{U}_{3} \mathrm{O}_{8}$ and from about 230 to $380 \mathrm{pCi} / \mathrm{L}\left(910\right.$ to $1,600 \mathrm{~g} / \mathrm{L}$ ) for disposal of $\mathrm{UO}_{2}$. These uranium concentrations would exceed the guideline of $20 \mathrm{~g} / \mathrm{L}$ used for comparison. If the uranium moved less rapidly through the soil surrounding the disposal facility, uranium concentrations in the groundwater beneath the facility after 1,000 years could be much less than the guideline value. However, the concentrations would increase with time, ultimately approaching the concentrations discussed for the mobile situation, and exceeding the guideline.

For both $\mathrm{U}_{3} \mathrm{O}_{8}$ and $\mathrm{UO}_{2}$, larger groundwater concentrations were estimated over the long term for disposal of grouted waste compared with ungrouted waste because grouting would increase the waste volume, essentially exposing a larger cross section of material to infiltrating water. However, further studies using site-specific soil characteristics would be necessary to determine the effect of grouting on long-term waste mobility. Grouting might reduce the dissolution of the waste and subsequent leaching of uranium into the groundwater in the first several hundred years after failure. However, over longer periods, the grouted form would be expected to deteriorate and, because of the long half-life of uranium, the performance of grouted and ungrouted waste would be essentially the same. Depending on soil properties, it is also possible that grouting could increase the solubility of the uranium material, resulting in more rapid groundwater contamination.

The potential impacts on groundwater would be essentially similar for disposal in shallow earthen structures, vaults, and or a mine because of the long time periods considered and the fact that the calculations were performed for 1,000 years after each facility was assumed to fail. However, shallow earthen structures would be expected to contain the waste material for a period of several hundred years before failure, and vaults and a mine would be expected to last even longer. Therefore, vault and mine disposal would provide greater protection in a wet environment. In addition, a vault 
or a mine would be expected to provide additional protection against erosion of the cover material (and possible exposure of the waste material) compared with shallow earthen structures. The exact time that any disposal facility would perform as designed would depend on the specific facility design and site characteristics.

\subsection{Ecology}

\subsubsection{Construction Impacts for Vault or Underground Mine Disposal}

Moderate to large impacts to ecological resources could result from construction of a facility for disposal of $\mathrm{U}_{3} \mathrm{O}_{8}$ or $\mathrm{UO}_{2}$. Impacts could include mortality of individual organisms, habitat loss, or changes in biotic communities. Existing vegetation would be destroyed during land clearing activities. The vegetative communities that would be eliminated by site preparation would depend on the actual location of the facility. Although herbaceous vegetation could be reestablished relatively rapidly in a wet setting (with at least $40 \mathrm{in} . / \mathrm{yr}[100 \mathrm{~cm} / \mathrm{yr}]$ precipitation), such as in the eastern United States, a considerable period of time might be required in a dry setting (less than 10 in./yr [25 cm/yr] precipitation), such as in the western United States.

Wildlife would be disturbed by land clearing, noise, and human presence. Wildlife with restricted mobility, such as burrowing species or juveniles of nesting species, would be destroyed during land clearing activities. Mobile individuals would relocate to adjacent available areas with suitable habitat. Population densities and competition would increase in these areas, potentially reducing the chances of survival or reproductive capacity of displaced individuals. Some wildlife species would be expected to recolonize replanted areas near the disposal facility following completion of construction. However, habitat use in the vicinity of the facility might be reduced for some species due to the construction of a perimeter fence.

Wetlands could potentially be impacted by filling or draining during construction. In addition, impacts to wetlands and aquatic habitats due to alteration of surface water runoff patterns, soil compaction, or groundwater flow could occur if the disposal facility was located adjacent to wetland or aquatic areas. However, impacts would be minimized by maintaining a buffer area around wetlands and aquatic habitats during construction of the facility. Unavoidable impacts to wetlands would require a Clean Water Act Section 404 permit, which might stipulate mitigative measures. Additional permitting might be required by state agencies. Depending on the facility location, water withdrawal from surface waters or groundwater, as well as wastewater discharge, could potentially alter water levels, which could in turn affect aquatic ecosystems, including wetlands, especially those located along the periphery of these surface water bodies.

Prior to construction of a disposal facility, a survey for state and federally listed threatened, endangered, or candidate species, or species of special concern would be conducted so that, if possible, impacts to these species could be avoided. Where impacts were unavoidable, appropriate mitigation could be developed. 


\subsubsection{Operational Phase}

Ecological resources in the vicinity of the wasteform facility would be exposed to atmospheric emissions from facility operation; however, emission levels would be expected to be extremely low (Section 5.2). At $750 \mathrm{ft}(230 \mathrm{~m})$ away, the highest annual average air concentration of $\mathrm{U}_{3} \mathrm{O}_{8}$ or $\mathrm{UO}_{2}$ due to operation of the facility would be $1.6 \times 10^{-5}$ or $3 \times 10^{-5} \mathrm{~g} / \mathrm{m}^{3}$, respectively. Resulting impacts to biota would be negligible.

Facility accidents, as discussed in Section 5.3, could result in adverse impacts to ecological resources. The affected species and degree of impact would depend on a number of factors, such as location of the accident, season, and meteorological conditions.

\subsubsection{Post-Closure Phase}

Potential impacts to aquatic biota could occur in the future if the disposal facility were to fail. Failure of facility integrity could result in contamination of groundwater at a wet setting within 1,000 years, as described in Section 6.2.3. Groundwater could discharge to the surface (such as in wetland areas) near the facility, thus exposing biota to contaminants. Groundwater concentrations of uranium calculated for 1,000 years after facility failure would range up to about $510 \mathrm{pCi} / \mathrm{L}$ (includes impact of USEC-generated DU). Adverse impacts to aquatic biota could result from exposure to soluble uranium compounds within this concentration range, although the resulting dose rates to maximally exposed organisms would be considerably less than the dose limit of $1 \mathrm{rad} / \mathrm{d}$ for aquatic organisms, as specified in DOE Order 5400.5. These potential ecological impacts, which correspond to the groundwater concentration estimated for 1,000 years after failure of the disposal facility, are highly uncertain and would depend on site-specific characteristics and on whether aquatic biota would actually contact contaminants. A summary of impacts is given in Table 6.3.

The impacts presented in the remainder of this section are associated with disposal of only the DOE-generated depleted uranium. Inclusion of the USEC-generated depleted uranium would increase impacts by approximately 20\% (DOE 1999).

\subsubsection{Disposal as $\mathrm{U}_{3} \mathrm{O}_{8}$}

The disposal facilities considered would be expected to adequately prevent the release of their contents for considerable periods of time. Impacts to ecological resources due to the presence of the facility would not be expected to occur prior to facility failure. Failure of facility integrity would result in contamination of groundwater if the facility was located in a wet environmental setting (typical of the eastern United States, with at least 40 in./yr [100 cm/yr] precipitation). Groundwater could discharge to the surface (such as in wetland areas) near the facility, thus exposing biota to contaminants. Groundwater concentrations of schoepite $\left(\mathrm{UO}_{3} 2 \mathrm{H}_{2} \mathrm{O}\right)$ were calculated for 1,000 years after facility failure. Schoepite concentrations would be nearly zero throughout the time period analyzed for a disposal facility located in a dry environmental setting (typical of the western United States, with less than $10 \mathrm{in} . / \mathrm{yr}$ [25 cm/yr] precipitation). Ecological impacts are summarized in Table 6.3.

Failure of a shallow earthen structure disposal facility would result in groundwater concentrations of schoepite near the facility ranging from $3.1 \times 10^{-6}$ to $1.1 \times 10^{-3} \mathrm{~g} / \mathrm{L}(0.003$ to 1.5 $\mathrm{ppm})$. Soluble uranium compounds can produce toxic effects in aquatic biota at concentrations as 
low as $1.5 \times 10^{-4} \mathrm{~g} / \mathrm{L}(0.15 \mathrm{ppm})$. An organism continuously exposed to the undiluted groundwater could therefore be adversely impacted by the toxic effects of uranium. Uranium activity would range from 2.0 to $270 \mathrm{pCi} / \mathrm{L}$. Resulting dose rates to maximally exposed organisms would be considerably lower than the dose limit of $1 \mathrm{rad} / \mathrm{d}$ for aquatic organisms specified in DOE Order 5400.5.

Failure of a facility for disposal in vaults would result in groundwater concentrations of schoepite ranging from $9.7 \times 10^{-6}$ to $1.3 \times 10^{-3} \mathrm{~g} / \mathrm{L}(0.01$ to $1.3 \mathrm{ppm})$. Therefore an organism continuously exposed to this undiluted groundwater could be adversely impacted by the toxic effects of uranium. Uranium activity would range from 2.4 to $315 \mathrm{pCi} / \mathrm{L}$. Resulting dose rates to maximally exposed organisms would be considerably lower than the dose limit of $1 \mathrm{rad} / \mathrm{d}$.

Failure of a mine disposal facility would result in groundwater concentrations ranging from 0 to $1.7 \times 10^{-3} \mathrm{~g} / \mathrm{L}(1.7 \mathrm{ppm})$. Adverse impacts to aquatic biota could result from exposure to soluble uranium compounds within this concentration range. Uranium activity would range from 0 to 425 $\mathrm{pCi} / \mathrm{L}$. Resulting dose rates to maximally exposed organisms would be considerably lower than the dose limit of $1 \mathrm{rad} / \mathrm{d}$.

\subsubsection{Disposal as $\mathrm{UO}_{2}$}

Groundwater schoepite concentrations resulting from the failure of a facility for disposal of $\mathrm{UO}_{2}$ would also be nearly zero at 1,000 years for a facility in a dry environmental setting. Groundwater concentrations for disposal of $\mathrm{UO}_{2}$ in a wet environmental setting would be similar to those for disposal of $\mathrm{U}_{3} \mathrm{O}_{8}$.

Failure of a shallow earthen structure facility would result in groundwater concentrations of schoepite near the facility ranging from $6.9 \times 10^{-6}$ to $8.2 \times 10^{-4} \mathrm{~g} / \mathrm{L}(0.007$ to $0.82 \mathrm{ppm})$. Soluble uranium compounds can produce toxic effects in aquatic biota at concentrations as low as $1.5 \times 10^{-4}$ $\mathrm{g} / \mathrm{L}(0.15 \mathrm{ppm})$. An organism continuously exposed to the undiluted groundwater could be adversely impacted by the toxic effects of uranium. Uranium activity would range from 1.7 to $204 \mathrm{pCi} / \mathrm{L}$. Resulting dose rates to maximally exposed organisms would be considerably lower than the dose limit of $1 \mathrm{rad} / \mathrm{d}$.

Failure of a facility for disposal in vaults would result in groundwater concentrations of schoepite ranging from $6.9 \times 10^{-6}$ to $8.4 \times 10^{-4} \mathrm{~g} / \mathrm{L}(0.007$ to $0.84 \mathrm{ppm})$. Therefore, an organism continuously exposed to this undiluted groundwater could be adversely impacted by the toxic effects of uranium. Uranium activity would range from 1.7 to $209 \mathrm{pCi} / \mathrm{L}$. Resulting dose rates to maximally exposed organisms would be considerably lower than the dose limit of $1 \mathrm{rad} / \mathrm{d}$.

Failure of a mined cavity disposal facility would result in groundwater schoepite concentrations ranging from 0 to $1.3 \times 10-3 \mathrm{~g} / \mathrm{L}(1.3 \mathrm{ppm})$. Adverse impacts to aquatic biota could result from exposure to soluble uranium compounds within this concentration range. Uranium activity would range from 0 to $316 \mathrm{pCi} / \mathrm{L}$. Resulting dose rates to maximally exposed organisms would be considerably lower than the dose limit of $1 \mathrm{rad} / \mathrm{d}$. 


\section{SUMMARY}

\subsection{Waste Forms}

The most suitable waste form for disposal of depleted uranium is $\mathrm{U}_{3} \mathrm{O}_{8}$, followed by $\mathrm{UO}_{2}$, either grouted or ungrouted. As discussed in Section 2.5, these forms would be the most stable under disposal repository conditions when exposed to ground water after containment is eventually breached. With the exception of Hanford, the oxides considered in this report meet the WAC of the existing low-level waste disposal facilities described in Section 4.4 and can be found in natural deposits in the environment. At Hanford, the oxides may require stabilization or repackaging. The other DU forms considered were less stable than the oxides. The fluorides considered, $\mathrm{UF}_{6}, \mathrm{UF}_{4}$, and $\mathrm{UO}_{2} \mathrm{~F}_{2}$, either react violently with water to produce toxic fumes $\left(\mathrm{UF}_{6}\right.$ and $\left.\mathrm{UF}_{4}\right)$ or are at least partially soluble in water $\left(\mathrm{UF}_{4}\right.$ and $\left.\mathrm{UO}_{2} \mathrm{~F}_{2}\right)$. The pyrophoric nature of uranium metal powder makes it an unacceptable waste form under any WAC. Disposal as bulk metal in its pure form may be excluded by the current Envirocare and Hanford WACs because of its specific activity. A change in the current WAC or another solution that would reduce the activity concentration in the wasteform may be required. For all disposal sites, some type of special packaging or pre-treatment of the metal to prevent eventual reaction with groundwater may be required.

Using estimates from the PEIS that include both the DOE- and USEC-generated DU, approximately 945,000 55-gallon drums would be required for disposal of ungrouted $\mathrm{U}_{3} \mathrm{O}_{8}$; if grouted, approximately 1,980,000 drums. Disposal of ungrouted $\mathrm{UO}_{2}$ would require approximately 556,000 30-gallon drums or approximately 834,000 drums if grouted. If in bulk metal form, approximately 797,000 billet boxes would require disposal.

\subsection{Applicable Regulations}

The purified forms of depleted uranium that are in the DOE inventory are "source material" as defined by the AEA. RCRA excludes source material from the definitions of solid and hazardous waste. Therefore, RCRA should not apply to management of depleted uranium when destined for disposal, as long as it is not mixed with other materials that would be governed by RCRA (i.e., as long as it is not a component of mixed waste). Only the legal requirements applicable to disposal of radioactive materials should apply.

Depleted uranium destined for disposal would be classified in the category of low-level radioactive waste under DOE Orders and NRC regulations. As such, the depleted uranium has characteristics that would allow its disposal in either a DOE low-level waste disposal facility meeting the requirements of Order DOE O 435.1, or in a non-DOE low-level waste disposal facility that is licensed by NRC or an Agreement State under 10 CFR Part 61. To receive depleted uranium in oxide or metal form for disposal, the radioactive waste management basis for a DOE low-level waste disposal facility would have to address such material. In addition, the depleted uranium would have to meet the DOE facility's waste acceptance criteria. Regarding non-DOE facilities, DOE policy prohibits disposal of DOE-generated low-level waste in non-DOE facilities, unless DOE disposal 
capabilities are not practical or cost effective, and the responsible DOE Field Element Manager approves an exception. Therefore, before DOE could choose a non-DOE disposal facility to receive depleted uranium, the Department would have to either change its existing low-level waste disposal policy or the necessary exemptions would have to be approved. Assuming one of these events occurs, NRC regulations would allow disposal of depleted uranium oxides or metal in a low-level waste disposal facility using any of the methods being considered by DOE, provided that the facility meets mandated performance criteria and technical requirements.

\subsection{Disposal Facilities}

Three different types of disposal facilities were investigated for the permanent disposal of the depleted uranium inventory. Operational and post-closure phase environmental impacts were estimated for each type of facility operating in two different environmental settings. Current LLW disposal sites were investigated and their available capacities and costs determined.

\subsubsection{Facility Types}

Three disposal options were considered, including disposal in shallow earthen structures, belowground vaults, and an underground mine. Shallow earthen structures, commonly referred to as engineered trenches, are among the most commonly used forms of low-level waste disposal, especially in dry climates. Disposal in shallow earthen structures would consist of placing waste on a stable structural pad with barrier walls typically constructed of compacted clay. The waste containers would be tightly stacked and any open space between containers would be filled with earth, sand, gravel, or other similar material as each layer of drums was emplaced. After the structure was filled, a thick cap composed of engineered fill dirt and clay would be placed on top and compacted.

Belowground vaults are subsurface reinforced concrete structures. As opposed to shallow earthen structures, the walls and floor of a vault would be constructed of reinforced concrete. Once a vault was full, any open space between containers would be filled with earth, sand, gravel, or other similar material. A permanent roof slab of reinforced concrete that completely covers the vault would be installed after the vault was filled. A cap of engineered fill dirt and clay would be placed on top of the concrete cover and compacted.

An underground mine disposal facility would be a repository for permanent deep geological disposal. A mined disposal facility could possibly use a previously existing mine, or be constructed for the sole purpose of waste disposal. Waste containers would be placed in drifts (underground tunnels) and backfilled.

\subsubsection{Environmental Settings}

The potential environmental settings for disposal of depleted uranium were based on data representing a dry setting and a wet setting. Both the dry and wet settings were assumed to be in a rural environment with an average population density of 15 persons $/ \mathrm{mi}^{2}\left(6\right.$ persons $\left./ \mathrm{km}^{2}\right)$.

For the representative dry setting, a disposal facility was assumed to be located in an arid to semiarid climate. Under these conditions, annual precipitation typically would be about $10 \mathrm{in} . / \mathrm{yr}$ 
(25 cm/yr). Approximately $1 \%$ of the annual rainfall, or about $0.1 \mathrm{in} . / \mathrm{yr}(0.25 \mathrm{~cm} / \mathrm{yr})$, would be expected to infiltrate the ground, recharging the groundwater. The remainder of the precipitation would be lost to runoff or evapotranspiration (evaporation plus plant transpiration). The groundwater aquifer was assumed to be located at a depth of about $500 \mathrm{ft}(150 \mathrm{~m})$ below the surface. This aquifer was assumed to consist of $100 \mathrm{ft}(30 \mathrm{~m})$ of semiconsolidated sands, gravels, silts, and clays.

For the generic wet setting, a disposal facility was assumed to be in a modified continental climate. Under these conditions, annual precipitation would be about 40 in./yr $(100 \mathrm{~cm} / \mathrm{yr})$. About $50 \%$ of the rainfall would be expected to be lost to runoff and evapotranspiration, with the remainder, $20 \mathrm{in.} / \mathrm{yr}(51 \mathrm{~cm} / \mathrm{yr})$, infiltrating the ground and recharging the underlying groundwater aquifer. The groundwater aquifer was assumed to be located at a depth of about $30 \mathrm{ft}(9 \mathrm{~m})$ below the surface. This aquifer was assumed to consist of $20 \mathrm{ft}(6.1 \mathrm{~m})$ of semiconsolidated sands, gravels, silts, and clays.

The impacts analyses performed for the PEIS and summarized here would suggest that the preferred setting for a disposal facility for DU would be in a dry environmental setting, as opposed to a wet environmental setting as discussed below.

\subsubsection{Available Facilities}

Five currently operating LLW sites, 2 DOE and 3 commercial, were identified as potential disposal sites for depleted uranium. The 2 DOE operated sites, the Hanford Site and the NTS, and two commercial sites, Envirocare and WCS, are located in a dry environmental setting. The third commercial site, Barnwell, is located in a wet environmental setting. WCS currently has only a license to treat and store LLW. The site was included for analysis because it is in the process of attempting to obtain a license for LLW disposal from the state of Texas. With the exception of Barnwell, all sites dispose of waste in shallow earthen structures. Barnwell disposes of wastes in vaults.

\subsubsection{Capacity}

Hanford, NTS, and Envirocare all have sufficient capacity for the entire amount of DU considered in any form (see Section 4.4.8, Table 4.1) in addition to future projections of waste from other sources. In the case of WCS, it potentially has sufficient capacity, but its interim storage license would only allow for receiving approximately one-tenth of the DU inventory under consideration. Barnwell has limited capacity that is not large enough to accommodate the entire amount of the DU if disposed as grouted $\mathrm{UO}_{2}$ or ungrouted or grouted $\mathrm{U}_{3} \mathrm{O}_{8}$. Barnwell is also unlikely to have enough capacity for the entire amount of the DU in addition to its other commitments.

\subsubsection{Cost}

Hanford and NTS have the lowest disposal rates at approximately $\$ 7$ to $\$ 8$ per cubic foot, approximately half the cost of the nearest competitor, Envirocare (see Section 4.4.9, Table 4.1). Disposal costs at the DOE sites ranged from approximately $\$ 15$ million to $\$ 116$ million for disposal of DU as ungrouted $\mathrm{UO}_{2}$ and grouted $\mathrm{U}_{3} \mathrm{O}_{8}$, respectively. These costs are for disposal only and do not include costs for wasteform or disposal facility construction, conversion of $\mathrm{UF}_{6}$, transportation of the waste forms to the disposal location, and regulatory compliance costs. In addition, disposal costs at Hanford may increase by a factor of approximately 4 if the preferred DU wasteform requires 
disposal in a high integrity container in order to meet performance criteria at the site. Disposal costs at the other sites may also be higher if repackaging of the DU is necessary.

\subsection{Environmental Impacts}

The potential impacts from disposal were estimated for two phases: (1) the operational phase, which includes operation of facilities and is the period during which drums would be actively placed into disposal units, and (2) the post-closure phase, which extends up to 1,000 years in the future after the assumed failure of the disposal units. No matter how well designed, all disposal facilities would be expected to release material to the environment (or "fail") eventually. In general, shallow earthen structures would be expected to contain waste material for at least several hundred years before failure, and vaults and mines would be expected to last even longer. For purposes of analysis in the PEIS, failure of all three types of disposal facilities was assumed to occur at the end of a period of institutional control, 100 years after closure. Because of the infiltration of water, uranium could ultimately migrate through the soil or bedrock in the case of a mined cavity and eventually contaminate the groundwater. The potential impacts during the post-closure phase would result from using contaminated groundwater that could affect members of the general public.

Operational phase impacts to human health were found to be minimal. No fatalities were expected over the 26 years of operation (see Tables 5.1 and 5.2). Approximately 100 to 200 worker injuries might be expected over the same period (see Table 5.2). Worker impacts were proportional to the number of waste packages handled, being largest for the grouted $\mathrm{U}_{3} \mathrm{O}_{8}$ option and the lowest for the ungrouted $\mathrm{UO}_{2}$ option. Air concentrations of criteria pollutants from facility operations were estimated to be well within regulatory guidelines. Resulting impacts to biota from air and water emissions would be negligible.

Post-closure phase environmental impacts (Section 6) for disposal facilities located in a dry environment were estimated to be negligible. The same impacts for disposal facilities located in a wet environment could have adverse affects on human health and aquatic biota. For a wet environment, uranium concentrations after 1,000 years were highest for shallow earthen structures and lowest for mine disposal, and slightly higher for $\mathrm{U}_{3} \mathrm{O}_{8}$ than for $\mathrm{UO}_{2}$. Over the long-term, the grouted forms did not offer additional protection because they were assumed to eventually disintegrate and expose higher cross-sections of waste to infiltrating groundwater. The long-term calculations were highly uncertain because of such assumptions. Shallow land burial in a wet environment was also found not to comply with the performance criteria in 10 CFR 61.41 as estimated by the NRC for depleted uranium (Section 3.3.2.2).

\subsection{Conclusions}

The most suitable depleted uranium waste form for disposal appears to be ungrouted $\mathrm{U}_{3} \mathrm{O}_{8}$ when taking into consideration the stability of the potential waste forms (Section 2.5) and the potential impacts to the environment (Sections 5 and 6). Under potential repository conditions, $\mathrm{U}_{3} \mathrm{O}_{8}$ is the most stable uranium compound considered. Grouting of the oxide adds bulk but does not ensure added protection in the long-term because of uranium's long half-life. Both the National Research Council (1996) and the U.S. NRC (NRC 1994) support the disposal of DU as $\mathrm{U}_{3} \mathrm{O}_{8}$. 
The most suitable disposal site could be at either Hanford or NTS. Both sites are DOE sites, are located in dry environments, can easily accommodate the anticipated volumes of DU, and currently have the lowest disposal costs. The preferred disposal site for DOE generated waste is a DOE facility (Section 3.3). Hanford and NTS are both located in dry environments. In the PEIS, long-term impacts were estimated to be negligibly small in a facility located in a dry environment. Both Hanford and NTS have sufficient projected capacity, not including options for future expansion, to dispose of all of the DU material. Hanford and NTS also have comparable disposal costs, the lowest of the disposal sites investigated. However, $\mathrm{U}_{3} \mathrm{O}_{8}$ may require additional packaging for disposal at Hanford. Also, the $\mathrm{UO}_{2}$ and metal forms do not meet concentration limits for U-238 in the current Hanford WAC, but they may be accepted depending on the outcome of a performance assessment study. In order to be accepted, these wasteforms may require additional packaging or stabilization which would increase costs. 


\section{REFERENCES}

Ault, M. (U.S. Ecology) Private communication with M. Goldberg (ANL), July 12, 1999.

Blake, E. M., 1999, “Crossroads or Dead End: LLW Disposal in the United States,” Radwaste 6(3): 9-16.

Blanchard, V. (Hanford) Private communication with B. Biwer (ANL), August 31, 1999.

Cooper, T.D., et al., 1996, "Pyrophoricity and Ignition of Bulk Uranium Metal," in Proceedings of the International Topical Meeting on Nuclear and Hazardous Waste Management (Spectrum '96), Aug. 18-23, Seattle, WA, pp. 2448-2452.

Garcia, R. (Hanford) Private communication with M. Goldberg (ANL), July 12, 1999.

Hertzler, T.J., et al., 1994, Depleted Uranium Disposal Options Evaluation, EGG-MS-11297, prepared by Science Applications International Corporation, Idaho Falls, Idaho, for EG\&G Idaho, Inc., and the U.S. Department of Energy, Office of Environmental Restoration and Waste Management, May.

Katz, J.J., and E. Rabinowitch, 1951, The Chemistry of Uranium Part I, The Element, Its Binary and Related Compounds (McGraw-Hill, New York).

Kirk-Othmer, 1997, Encyclopedia of Chemical Technology, Vol. 24, $4^{\text {th }}$ Edition, published by John Wiley \& Sons, New York, NY.

Lawrence Livermore National Laboratory, 1997a, Depleted Uranium Hexafluoride Management Program; the Engineering Analysis Report for the Long-Term Management of Depleted Uranium Hexafluoride, UCRL-AR-124080, Volumes I and II, Revision 2, prepared by Lawrence Livermore National Laboratory, Science Applications International Corporation, Bechtel, and Lockheed Martin Energy Systems for U.S. Department of Energy, May.

Lawrence Livermore National Laboratory, 1997b, Cost Analysis Report for the Long-Term Management of Depleted Uranium Hexafluoride, UCRL-AR-127650, prepared by Lawrence Livermore National Laboratory, Lawrence, Calif., for U.S. Department of Energy, May.

Loveland, K. (Envirocare), 1999a, Private communication with B. Biwer (ANL), Aug. 23.

Loveland, K. (Envirocare), 1999b, Private communication with M. Goldberg (ANL), July 13.

McGuire, S.A., 1991, Chemical Toxicity of Uranium Hexafluoride Compared to Acute Effects of Radiation, Final Report, NUREG-1391, U.S. Nuclear Regulatory Commission, Office of Nuclear Regulatory Research, Washington, D.C., Feb. 
National Research Council, 1996, "Disposition of the DUF6," Chapter 7 in Affordable Cleanup? Opportunities for Cost Reduction in the Decontamination and Decommissioning of the Nation's Uranium Enrichment Facilities, Board on Energy and Environmental Systems, National Academy Press, Washington, D.C.

National Safety Council, 1995, Accident Facts, 1995 Edition, Itasca, Ill.

Policastro, A.J., et al., 1997, Facility Accident Impact Analyses in Support of the Depleted Uranium Hexafluoride Programmatic Environmental Impact Statement, attachment to memorandum from A.J. Policastro (Argonne National Laboratory, Argonne, Ill.) to H.I. Avci (Argonne National Laboratory, Argonne, Ill.), June 15.

Pyles, G. (NTS) Private communication with M. Goldberg (ANL), July 12, 1999.

Rice, R.C., et al., 1989, "Ionic Composition of Vadose Zone Water in an Arid Region," Ground Water 27(6):813-822.

Solbrig, C.W., et al., 1994, Pyrophoricity of Uranium in Long-Term Storage Environments, ANL/TD/CP--84441, Argonne National Laboratory, Argonne, Ill.

Still, J. (Barnwell) Private communication with M. Goldberg (ANL), July 13, 1999.

Swanstrom, C., et al., 1997, Issue Paper: Technology Impact Review - Vitrification of Uranium Oxides Resulting from Conversion of Depleted Uranium Hexafluoride, attachment to memorandum from C. Swanstrom et al. (Argonne National Laboratory, Argonne, Ill.) to H.I. Avci (Argonne National Laboratory, Argonne, Ill.), May 21.

U.S. Department of Energy, 1990, Letter from J. La Grone, Manager, Oak Ridge Operations Office, to Ohio EPA (R. Shank, Director), October 29.

U.S. Department of Energy, 1995, Depleted Uranium: A DOE Management Challenge, DOE/EM0262, Office of Environmental Management, Office of Technology Development, Washington, D.C., Oct.

U.S. Department of Energy, 1996a, Material in Inventory: Depleted Uranium Final Report, Depleted Uranium Materials In Inventory Team, January 15.

U.S. Department of Energy, 1996b, 1995 Annual Report on Low-Level Radioactive Waste Management Progress, DOE/EM-0292, June.

U.S. Department of Energy, 1996c, Final Environmental Impact Statement for the Nevada Test Site and Off-Site Locations in the State of Nevada, DOE/EIS-0243, Nevada Operations Office, Las Vegas, NV, Aug.

U.S. Department of Energy, 1998a, The Current and Planned Low-Level Waste Disposal Capacity Report, Rev. 1, Office of Environmental Management, Washington, D.C., Sept. 
U.S. Department of Energy, 1998b, Information Package on Pending Low-Level Waste and Mixed Low-Level Waste Disposal Decisions, Sept.

U.S. Department of Energy, 1999, Final Programmatic Environmental Impact Statement for Alternative Strategies for the Long-Term Management and Use of Depleted Uranium Hexafluoride, DOE/EIS-0269, Office of Nuclear Energy, Science, and Technology, Germantown, MD, Apr.

U.S. Environmental Protection Agency, 1986, Test Method 1311 in "Test Methods for Evaluating Solid Waste, Physical/Chemical Methods," EPA Publication SW-846, as incorporated by reference in 40 CFR $\$ 260.11$ (as amended).

U.S. Nuclear Regulatory Commission, 1994a, Final Environmental Impact Statement for the Construction and Operation of Claiborne Enrichment Center, Homer, Louisiana, Docket No. 703070, NUREG-1484, Volumes 1 and 2, Office of Nuclear Material Safety and Safeguards, Washington, D.C, Aug.

U.S. Nuclear Regulatory Commission, 1994b, "10 CFR Part 19, et al., Certification of Gaseous Diffusion Plants; Final Rule," discussion on Section 76.85, "Assessment of Accidents," Federal Register 59(184):48954-49855, Sept. 23.

WHC, 1996, High Integrity Container, 300 Year, WHC-S-0486, Westinghouse Hanford Company, Richland, Washington. 
Table 1.1 Inventory of Standard 48-Inch DUF ${ }_{6}$ Cylinders

\begin{tabular}{lcccc}
\hline Site & $\begin{array}{c}\text { Original } \\
\text { DOE } \\
\text { Cylinders }\end{array}$ & $\begin{array}{c}\text { Cylinders } \\
\text { from } \\
\text { USEC }^{\mathrm{a}}\end{array}$ & $\begin{array}{c}\text { Total } \\
\text { Cylinders }\end{array}$ & $\begin{array}{c}\text { Total DUF } \\
\text { (metric tons) }\end{array}$ \\
\hline Paducah & 28,351 & 8,559 & 36,910 & 450,000 \\
Portsmouth & 13,388 & 2,653 & 16,041 & 198,000 \\
K-25 & 4,683 & 0 & 4,683 & 56,000 \\
\hline Total & 46,422 & 11,212 & 57,634 & 704,000 \\
\hline
\end{tabular}

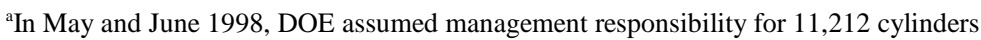
generated by USEC. For purposes of the disposal risk assessment, management of up to 15,000 USEC-generated cylinders was considered. 
Table 2.1 Physical Properties of Pertinent Uranium Compounds ${ }^{\mathrm{a}}$

\begin{tabular}{llccll}
\hline & & \multicolumn{2}{c}{ Density $\left(\mathrm{g} / \mathrm{cm}^{3}\right)$} & \\
\cline { 3 - 4 } \multicolumn{1}{c}{ Compound } & Melting Point $(\mathrm{C})$ & $\begin{array}{l}\text { Crystal/ } \\
\text { Particle }\end{array}$ & Bulk $^{\mathrm{a}}$ & & $\begin{array}{l}\text { Solubility in Water at } \\
\text { Ambient Temperature }\end{array}$ \\
\hline $\mathrm{UF}_{6}$ & 64.1 & & & \\
$\mathrm{UF}_{4}$ & $960 \pm 5$ & 5.1 & 5.1 & Decomposes to $\mathrm{UO}_{2} \mathrm{~F}_{2}$ \\
$\mathrm{UO}_{2} \mathrm{~F}_{2}$ & Decomposes to $\mathrm{U}_{3} \mathrm{O}_{8}$ at 300 & 6.37 & $\sim 2.6$ & Soluble \\
$\mathrm{U}_{3} \mathrm{O}_{8}$ & Decomposes to $\mathrm{UO}_{2}$ at 1,300 & 8.30 & $1.5-4.0$ & Insoluble \\
$\mathrm{UO}_{2}$ & $2,878 \pm 20$ & 10.96 & $2.0-5.0$ & Insoluble \\
$\mathrm{Uranium}$ & 1,132 & 19.05 & 19 & Insoluble \\
\hline
\end{tabular}

${ }^{a}$ Source: DOE (1999), Katz and Rabinowitch (1951), Kirk-Othmer (1997).

b Bulk densities of $\mathrm{UF}_{4}, \mathrm{UO}_{2} \mathrm{~F}_{2}, \mathrm{U}_{3} \mathrm{O}_{8}$, and $\mathrm{UO}_{2}$ are highly variable, depending on the production process and the properties of the starting uranium compounds.

Notation: $\mathrm{UF}_{4}=$ uranium tetrafluoride; $\mathrm{UF}_{6}=$ uranium hexafluoride; $\mathrm{UO}_{2}=$ uranium dioxide; $\mathrm{UO}_{2} \mathrm{~F}_{2}=$ uranyl fluoride; $\mathrm{U}_{3} \mathrm{O}_{8}=$ triuranium octaoxide. 




Figure 2.1 Uranium Hexafluoride Phase Diagram 
Table 3.1 Definitions of Radioactive Waste Categories

\begin{tabular}{|c|c|c|c|}
\hline Category & Statutes & NRC Regulations & DOE Orders \\
\hline $\begin{array}{l}\text { High-Level } \\
\text { Waste }\end{array}$ & $\begin{array}{l}\text { (A) The highly radioactive material resulting from } \\
\text { the reprocessing of spent nuclear fuel, including } \\
\text { liquid waste produced directly in reprocessing and } \\
\text { any solid material derived from such liquid waste } \\
\text { that contains fission products in sufficient } \\
\text { concentrations; and } \\
\text { (B) Other highly radioactive material that the [NRC], } \\
\text { consistent with existing law, determines by rule } \\
\text { requires permanent isolation.[ 42 U.S.C. \$10101(12)] }\end{array}$ & $\begin{array}{l}\text { (1) Irradiated reactor fuel, } \\
\text { (2) liquid wastes resulting from the operation of the first } \\
\text { cycle solvent extraction system, or equivalent, and the } \\
\text { concentrated wastes from subsequent extraction cycles, } \\
\text { or equivalent, in a facility for reprocessing irradiated } \\
\text { reactor fuel, and } \\
\text { (3) solids into which such liquid wastes have been } \\
\text { converted. [10 CFR §60.2] }\end{array}$ & $\begin{array}{l}\text { The highly radioactive waste material resulting from the } \\
\text { reprocessing of spent nuclear fuel, including liquid waste } \\
\text { produced directly in reprocessing and any solid material } \\
\text { derived from such liquid radioactive material that is } \\
\text { determined, consistent with existing law, to require } \\
\text { permanent isolation. [DOE M 435.1-1 at §II.A] }\end{array}$ \\
\hline $\begin{array}{l}\text { Spent } \\
\text { Nuclear Fuel }\end{array}$ & $\begin{array}{l}\text { Fuel that has been withdrawn from a nuclear reactor } \\
\text { following irradiation, the constituent elements of } \\
\text { which have not been separated by reprocessing. [ } 42 \\
\text { U.S.C. §10101(23)] }\end{array}$ & $\begin{array}{l}\text { Fuel that has been withdrawn from a nuclear reactor } \\
\text { following irradiation, has undergone at least one year's } \\
\text { decay since being used as a source of energy in a power } \\
\text { reactor, and has not been chemically separated into its } \\
\text { constituent elements by reprocessing. Spent fuel includes } \\
\text { the special nuclear material, byproduct material, source } \\
\text { material, and other radioactive materials associated with } \\
\text { fuel assemblies. [10 CFR §72.3] }\end{array}$ & $\begin{array}{l}\text { Fuel that has been withdrawn from a nuclear reactor } \\
\text { following irradiation, the constituent elements of which } \\
\text { have not been separated by reprocessing. Test } \\
\text { specimens of fissionable material irradiated for research } \\
\text { and development only, and not production of power or } \\
\text { plutonium, may be classified as waste, and managed in } \\
\text { accordance with the requirements of this Order [DOE O } \\
435.1 \text { ] when it is technically infeasible, cost prohibitive, } \\
\text { or would increase worker exposure to separate the } \\
\text { remaining test specimens from other contaminated } \\
\text { material. [DOE M 435.1-1 at Attachment 2, item 44] }\end{array}$ \\
\hline $\begin{array}{l}\text { Transuranic } \\
\text { Waste }\end{array}$ & $\begin{array}{l}\text { Waste containing more than } 100 \text { nanocuries of alpha- } \\
\text { emitting transuranic isotopes per gram of waste, with } \\
\text { half-lives greater than } 20 \text { years, except for: (1) high- } \\
\text { level radioactive waste; (2) waste that the Secretary } \\
\text { of Energy has determined, with the concurrence of } \\
\text { the Administrator [of the EPA], does not need the } \\
\text { degree of isolation required by the disposal } \\
\text { regulations; or (3) waste that the [NRC] has approved } \\
\text { for disposal on a case-by-case basis in accordance } \\
\text { with part } 61 \text { of title } 10 \text {, Code of Federal Regulations. } \\
\text { [WIPP Land Withdrawal Act of 1992, Pub. L. 102-- } \\
579,106 \text { Stat. } 4777 \text { (October 30, 1992), as amended, } \\
\text { at } \$ 2(20) \text { ] }\end{array}$ & Not defined. & $\begin{array}{l}\text { Radioactive waste containing more than } 100 \text { nanocuries } \\
\text { (3700 becquerels) of alpha-emitting transuranic isotopes } \\
\text { per gram of waste, with half-lives greater than } 20 \text { years, } \\
\text { except for: (1) High-level radioactive waste; (2) Waste } \\
\text { that the Secretary of Energy has determined, with the } \\
\text { concurrence of the Administrator of the [EPA], does not } \\
\text { need the degree of isolation required by the } 40 \text { CFR Part } \\
191 \text { disposal regulations; or (3) Waste that the [NRC] } \\
\text { has approved for disposal on a case-by-case basis in } \\
\text { accordance with } 10 \text { CFR Part 61. [DOE M 435.1-1 at } \\
\text { §III.A] }\end{array}$ \\
\hline $\begin{array}{l}\text { Low-Level } \\
\text { Waste }\end{array}$ & $\begin{array}{l}\text { Radioactive material that-(A) is not high-level } \\
\text { radioactive waste, spent nuclear fuel, or byproduct } \\
\text { material (as defined in section 11e.(2) of the Atomic } \\
\text { Energy Act of } 1954 \text { (42 U.S.C. 2014(e)(2)); and (B) } \\
\text { the [NRC], consistent with existing law and in } \\
\text { accordance with paragraph (A), classifies as low- } \\
\text { level radioactive waste. [42 U.S.C. } \$ 2021 \text { b(9)] }\end{array}$ & $\begin{array}{l}\text { Radioactive waste not classified as high-level radioactive } \\
\text { waste, transuranic waste, spent nuclear fuel, or byproduct } \\
\text { material as defined in section 11e.(2) of the Atomic } \\
\text { Energy Act (uranium or thorium tailings and waste). [10 } \\
\text { CFR §61.2] }\end{array}$ & $\begin{array}{l}\text { Radioactive waste that is not high-level radioactive } \\
\text { waste, spent nuclear fuel, transuranic waste, byproduct } \\
\text { material (as defined in section 11e.(2) of the Atomic } \\
\text { Energy Act of 1954, as amended), or naturally occurring } \\
\text { radioactive material. [DOE M 435.1-1 at §IV.A ] }\end{array}$ \\
\hline $\begin{array}{l}\text { \$11(e)(2) } \\
\text { Byproduct } \\
\text { Material }\end{array}$ & $\begin{array}{l}\text { The tailings or wastes produced by the extraction or } \\
\text { concentration of uranium or thorium from any ore } \\
\text { processed primarily for its source material content. } \\
\text { [42 U.S.C. } \$ 2014(3)(2)]\end{array}$ & $\begin{array}{l}\text { The tailings or wastes produced by the extraction or } \\
\text { concentration of uranium or thorium from any ore } \\
\text { processed primarily for its source material content, } \\
\text { including discrete surface wastes resulting from uranium } \\
\text { solution extraction processes. Underground ore bodies } \\
\text { depleted by such solution extraction operations do not } \\
\text { constitute "byproduct material" within this definition. [10 } \\
\text { CFR §40.4] }\end{array}$ & $\begin{array}{l}\text { The tailings or wastes produced by the extraction or } \\
\text { concentration of uranium or thorium from any ore } \\
\text { processed primarily for its source material content. [DOE } \\
\text { M 435.1-1 (July 9) at Attachment 2, item 2] }\end{array}$ \\
\hline
\end{tabular}


Table 3.2 Low-Level Waste Land Disposal Facility Performance Objectives

\begin{tabular}{|l|l|}
\hline 10 CFR Citation & Performance Objective \\
\hline$\S 61.40$ & $\begin{array}{l}\text { Land disposal facilities must be sited, designed, operated, closed, and controlled after } \\
\text { closure so that reasonable assurance exists that exposures to humans are within the } \\
\text { limits established in the performance objectives in §§61.41 through } 61.44 .\end{array}$ \\
\hline$\S 61.41$ & $\begin{array}{l}\text { Concentrations of radioactive material which may be released to the general } \\
\text { environment in ground water, surface water, air, soil, plants, or animals must not } \\
\text { result in an annual dose exceeding an equivalent of 25 millirems to the whole body, } 75 \\
\text { millirems to the thyroid, and } 25 \text { millirems to any other organ of any member of the } \\
\text { public. Reasonable effort should be made to maintain releases of radioactivity in } \\
\text { effluents to the general environment as low as is reasonably achievable. }\end{array}$ \\
\hline$\S 61.42$ & $\begin{array}{l}\text { Design, operation, and closure of the land disposal facility must ensure protection of } \\
\text { any individual inadvertently intruding into the disposal site and occupying the site or } \\
\text { contacting the waste at any time after active institutional controls over the disposal site } \\
\text { are removed. }\end{array}$ \\
\hline$\S 61.43$ & $\begin{array}{l}\text { Operations at the land disposal facility must be conducted in compliance with the } \\
\text { standards for radiation protection set out in 10 CFR Part 20, except for releases of } \\
\text { radioactivity in effluents from the land disposal facility, which shall be governed by } \\
10 \text { CFR } \S 61.41 . \text { Every reasonable effort shall be made to maintain radiation exposures } \\
\text { as low as is reasonably achievable. }\end{array}$ \\
\hline$\S 61.44$ & $\begin{array}{l}\text { The disposal facility must be sited, designed, used, operated, and closed to achieve } \\
\text { long-term stability of the disposal site and to eliminate to the extent practicable the } \\
\text { need for ongoing active maintenance of the disposal site following closure so that only } \\
\text { surveillance, monitoring, or minor custodial care are required. }\end{array}$ \\
\hline
\end{tabular}


Table 3.3 Summary of Technical Requirements for Near-Surface Land Disposal Facilities*

\begin{tabular}{|c|c|}
\hline 10 CFR Citation & Summary of Technical Requirements \\
\hline $\begin{array}{l}\$ 61.50(a), \text { Site } \\
\text { Suitability Requirements } \\
\text { for Near-Surface } \\
\text { Disposal }\end{array}$ & $\begin{array}{l}\text { Specifies minimum characteristics for the site of a near-surface disposal facility. } \\
\text { Prohibits near surface disposal in a 100-year floodplain, coastal high-hazard area, or } \\
\text { wetland (as defined in Executive Order } 11988 \text {, "Floodplain Management } \\
\text { Guidelines"). Prohibits waste disposal in the zone of fluctuation of the water table. } \\
\text { Prohibits waste disposal in a hydrogeologic unit that discharges ground water to the } \\
\text { surface within the disposal site. }\end{array}$ \\
\hline $\begin{array}{l}\text { \$61.51(a), Site Design } \\
\text { Requirements for Near- } \\
\text { Surface Disposal }\end{array}$ & $\begin{array}{l}\text { Specifies that site design must: } \\
\text { - } \quad \text { Isolate waste and avoid the need for continuing active maintenance after closure; } \\
\text { - } \quad \text { Complement and improve natural site characteristics, where appropriate; } \\
\text { - } \quad \text { Provide covers that minimize water infiltration, direct water away from disposed } \\
\text { waste, and resist degradation; } \\
\text { - } \quad \text { Drain surface water away from disposal units without erosion; and } \\
\text { Minimize water contact with waste to the extent practicable. }\end{array}$ \\
\hline $\begin{array}{l}\$ 61.52(a), \text { Facility } \\
\text { Operation and Site } \\
\text { Closure Requirements } \\
\text { for Near-Surface } \\
\text { Disposal }\end{array}$ & $\begin{array}{l}\text { (1) Class A wastes that do not meet the stability requirements in } 10 \text { CFR } \$ 61.56(\mathrm{~b}) \\
\text { must be placed in disposal units sufficiently separated from the disposal units } \\
\text { containing other classes of waste so that interaction between the Class A and other } \\
\text { wastes will not cause the facility's failure to meet the performance objectives. } \\
\text { (2) The top elevation of Class C wastes must be at least } 5 \text { meters below the elevation } \\
\text { of the top surface of the cover, or the unit must have intruder barriers designed to } \\
\text { protect against inadvertent intrusion for a least } 500 \text { years. } \\
\text { (3) All wastes must: } \\
\text { - Be placed in a manner that maintains the package integrity during } \\
\text { emplacement, minimizes the void spaces between packages, and permits the } \\
\text { void spaces to be filled. } \\
\text { Be placed and covered such that the radiation dose rate at the surface of the } \\
\text { closure period. } \\
\text { - Contain or be contaminated with radioactive materials. } \\
\text { (4) Void spaces between waste packages must be filled to reduce future subsidence. } \\
\text { (5) Each disposal unit must be accurately located and mapped. Markers must make } \\
\text { boundaries easy to define. Three permanent survey marker control points must be } \\
\text { established. } \\
\text { (6) A buffer zone must be maintained. } \\
\text { (7) Closure and stabilization measures must be carried out. } \\
\text { (8) Active waste disposal operations must not adversely affect completed closure and } \\
\text { stabilization measures. }\end{array}$ \\
\hline
\end{tabular}

*NOTE:The summaries provided in this table are not identical to the text in 10 CFR Part 61. Consult the regulations themselves for exact language and correct section numbers. 


\section{Table 3.4 Waste Characteristics and Stability Requirements*}

\begin{tabular}{|c|c|}
\hline 10 CFR Citation & Summary of Minimum Waste Characteristics \\
\hline $\begin{array}{l}\$ 61.56, \text { Waste } \\
\text { Characteristics }\end{array}$ & 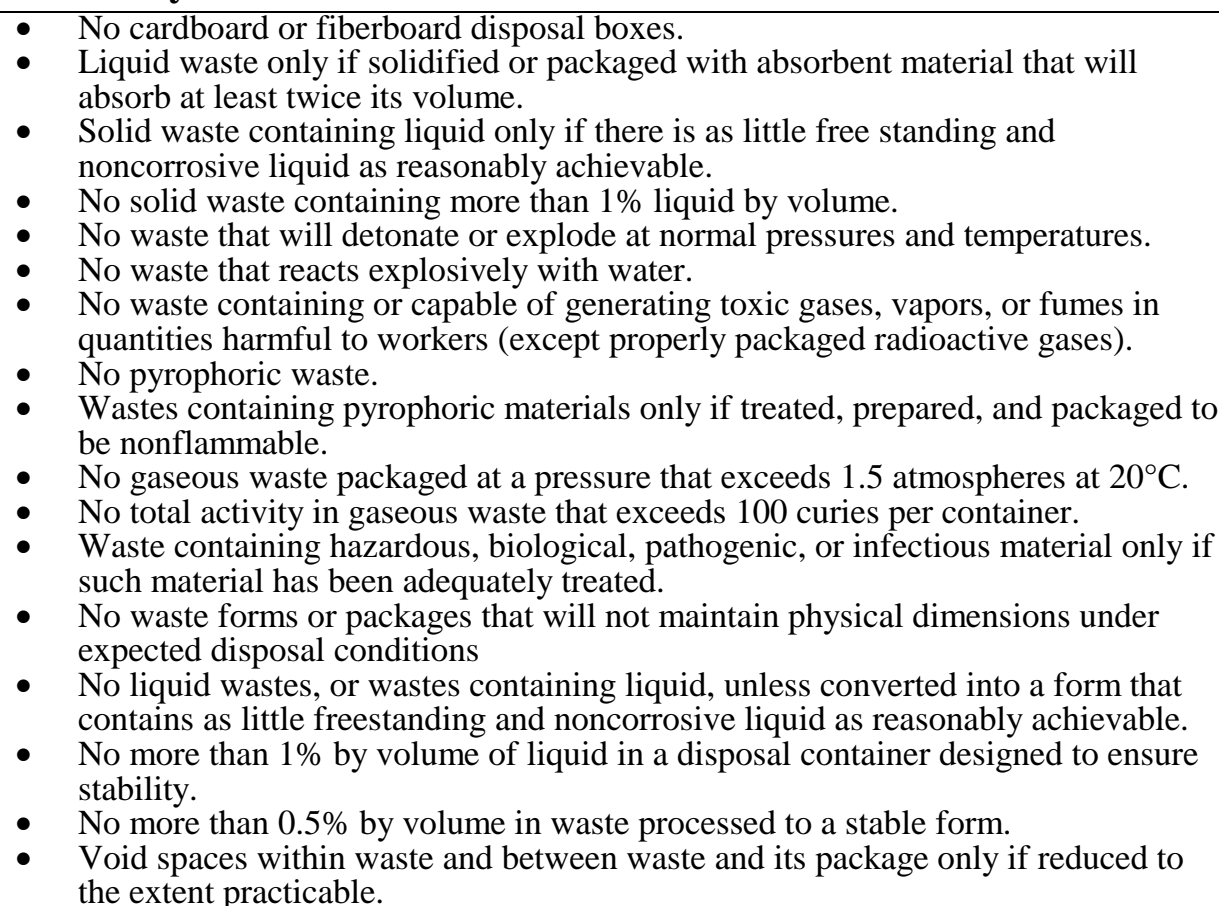 \\
\hline $\begin{array}{l}\$ 61.57 \text {, Labeling } \\
\text { Requirements }\end{array}$ & $\begin{array}{l}\text { Each package of waste must be clearly labeled to identify whether it is Class A waste, } \\
\text { Class B waste, or Class C waste. }\end{array}$ \\
\hline
\end{tabular}

*NOTE:The summaries provided in this table are not identical to the text in 10 CFR Part 61. Consult the regulations themselves for exact language and correct section numbers. 
Table 3.5 DOE Orders and Regulations Applicable to Low-Level Waste Disposal

\begin{tabular}{|c|c|}
\hline $\begin{array}{c}\text { Order Number or } \\
\text { Citation in } \\
10 \text { CFR }\end{array}$ & Title and Description \\
\hline DOE O 435.1 & $\begin{array}{l}\text { Radioactive Waste Management, which establishes requirements and responsibilities to } \\
\text { ensure that management of all DOE radioactive wastes protects the environment, worker } \\
\text { health and safety, and public health and safety. }\end{array}$ \\
\hline DOE O 210.1 & $\begin{array}{l}\text { Performance Indicators and Analysis of Operations Information, which requires } \\
\text { identification, collection and analyses of data that measure the environment, safety, and } \\
\text { health performance of radioactive waste management facilities, operations, and activities. }\end{array}$ \\
\hline DOE 5480.19 & $\begin{array}{l}\text { Conduct of Operation Requirements for DOE Facilities, which establish requirements for } \\
\text { ensuring that waste management facilities, operations, and activities consider associated } \\
\text { hazards in the conduct of their business. }\end{array}$ \\
\hline DOE 420.1 & $\begin{array}{l}\text { Facility Safety, which establishes facility safety program requirements related to nuclear } \\
\text { safety design, criticality safety, fire protection and natural phenomena hazards mitigation. }\end{array}$ \\
\hline DOE O 151.1 & $\begin{array}{l}\text { Comprehensive Emergency Management System, which requires radioactive waste } \\
\text { management facilities, operations, and activities to maintain an emergency management } \\
\text { program. }\end{array}$ \\
\hline DOE O 231.1 & $\begin{array}{l}\text { Environment, Safety and Health Reporting, and DOE O 232.1A, Occurrence Reporting } \\
\text { and Processing of Operations Information, which address reporting of information on } \\
\text { environment, safety and health. }\end{array}$ \\
\hline DOE 5400.1 & $\begin{array}{l}\text { General Environmental Protection Program, which requires radioactive waste } \\
\text { management facilities, operations, and activities to meet specified environmental } \\
\text { monitoring requirements. }\end{array}$ \\
\hline $\begin{array}{l}\text { DOE-STD-1027-92 } \\
\text { and/or DOE-EM- } \\
\text { STD-5502-94 }\end{array}$ & $\begin{array}{l}\text { Hazard Categorization and Accident Analysis Techniques for Compliance with DOE } \\
5480.23, \text { Nuclear Safety Analysis Reports, and/or DOE Limited Standard: Hazard } \\
\text { Baseline Documentation, which implement the requirement to prepare and maintain } \\
\text { hazard analysis documentation and an authorization basis in DOE O 425.1A, Startup and } \\
\text { Restart of Nuclear Facilities, DOE 5480.21, Unreviewed Safety Questions, DOE } \\
5480.22, \text { Technical Safety Requirements, and DOE 5480.23, Nuclear Safety Analysis } \\
\text { Reports. }\end{array}$ \\
\hline DOE O 430.1 & $\begin{array}{l}\text { Life Cycle Asset Management, which provides for the planning, acquisition, operation, } \\
\text { maintenance, and disposition of physical DOE assets as valuable national resources. }\end{array}$ \\
\hline DOE 4330.4B & $\begin{array}{l}\text { Maintenance Management Program, which requires implementation of a configuration } \\
\text { management process to ensure the integrity of physical assets and systems. }\end{array}$ \\
\hline DOE 460.1A & $\begin{array}{l}\text { Packaging and Transportation Safety, and DOE O } 460.2, \text { Departmental Materials } \\
\text { Transportation and Packaging Management, which establish requirements for the } \\
\text { packaging and transportation of radioactive wastes. }\end{array}$ \\
\hline 10 CFR 830.120 & $\begin{array}{l}\text { Quality Assurance Requirements, and DOE O 414.1, Quality Assurance, which require } \\
\text { development and maintenance of a quality assurance program. }\end{array}$ \\
\hline 10 CFR Part 835 & $\begin{array}{l}\text { Occupational Radiation Protection, which establishes radiation protection standards, } \\
\text { limits, and program requirements for protecting workers from exposure to ionizing } \\
\text { radiation during occupational duties associated with DOE activities. }\end{array}$ \\
\hline DOE 5400.5 & $\begin{array}{l}\text { Radiation Protection of the Public and the Environment, which establishes radiation } \\
\text { protection standards, limits, and program requirements for protecting individual members } \\
\text { of the public from exposure to ionizing radiation resulting from DOE activities. }\end{array}$ \\
\hline DOE O 200.1 & $\begin{array}{l}\text { Information Management Program, which requires radioactive waste management } \\
\text { facilities to develop and maintain a record-keeping system. }\end{array}$ \\
\hline DOE O 470.1 & $\begin{array}{l}\text { Safeguards and Security Program, which require the design and operation of nuclear } \\
\text { facilities to include features to prevent unauthorized access and operations }\end{array}$ \\
\hline
\end{tabular}




\begin{tabular}{|l|l|}
\hline $\begin{array}{c}\text { Order Number or } \\
\text { Citation in } \\
\text { 10 CFR }\end{array}$ & \multicolumn{1}{c|}{ Title and Description } \\
\hline DOE O 440.1A & $\begin{array}{l}\text { Worker Protection Management for DOE Federal and Contractor Employees, which } \\
\text { establishes the framework for an effective worker protection program that will reduce or } \\
\text { prevent injuries, illnesses, and accidental losses by providing DOE federal and contractor } \\
\text { workers with a safe and healthful workplace. }\end{array}$ \\
\hline $\begin{array}{l}\text { DOE O 360.1 and } \\
\text { DOE 5480.20A }\end{array}$ & $\begin{array}{l}\text { Training and Personnel Selection, Qualification, and Training Requirements for DOE } \\
\text { Nuclear Facilities, which require DOE facilities to implement a training and qualification } \\
\text { program for radioactive waste management program personnel. }\end{array}$ \\
\hline
\end{tabular}

\section{Table 3.6 Components of the Radioactive Waste Management Basis for DOE Low-Level Waste Disposal Facilities}

\begin{tabular}{|c|c|}
\hline $\begin{array}{l}\text { Section in } \\
\text { DOE M 435.1-1, } \\
\text { Chap. IV }\end{array}$ & Description of Component \\
\hline $\begin{array}{l}\text { Sec. P(2), } \\
\text { Performance } \\
\text { Assessment }\end{array}$ & $\begin{array}{l}\text { For wastes disposed of after September 26, 1988, the performance assessment must } \\
\text { demonstrate a reasonable expectation that operation and closure of the disposal facility will } \\
\text { not cause the performance objectives (see Table 3-9) to be exceeded during the first } 1,000 \\
\text { years after closure. The performance assessment must be maintained to evaluate changes } \\
\text { that could affect the performance, design, and operating bases for the facility, and must be } \\
\text { updated to support final facility closure. }\end{array}$ \\
\hline $\begin{array}{l}\text { Sec. } \mathrm{P}(3) \text {, } \\
\text { Composite Analysis }\end{array}$ & $\begin{array}{l}\text { For each disposal facility that receives waste after September 26, 1988, a site-specific } \\
\text { radiological composite analysis must demonstrate that the DOE standards and limits for } \\
\text { protection of the public and environment (see Order DOE 5400.5) will not be exceeded } \\
\text { during the first 1,000 years following closure of the disposal facility as a result of all } \\
\text { sources of radioactive material that may be left at the DOE site and may interact with the } \\
\text { disposal facility. The composite analysis must be maintained to evaluate changes that could } \\
\text { affect the performance, design, and operating bases for the facility. }\end{array}$ \\
\hline $\begin{array}{l}\text { Sec. P(5), Disposal } \\
\text { Authorization }\end{array}$ & $\begin{array}{l}\text { Before construction begins on any new low-level waste disposal facility, a disposal } \\
\text { authorization statement must be obtained, which specifies the limits and conditions on } \\
\text { construction, design, operations, and closure of the facility. Disposal authorization } \\
\text { statements are issued by the Deputy Assistant Secretaries for Waste Management and } \\
\text { Environmental Restoration based on a review of the facility's performance assessment, } \\
\text { composite analysis, performance assessment and composite analysis maintenance, } \\
\text { preliminary closure plan, and preliminary monitoring plan. }\end{array}$ \\
\hline $\begin{array}{l}\text { Sec. Q(1), Disposal } \\
\text { Facility Closure } \\
\text { Plan }\end{array}$ & $\begin{array}{l}\text { With the performance assessment and composite analysis, a preliminary closure plan must } \\
\text { be submitted to Headquarters. The plan must include a description of how the disposal } \\
\text { facility will be closed to achieve long-term stability and minimize the need for active } \\
\text { maintenance following closure, and an estimate of the total expected inventory of wastes to } \\
\text { be disposed over the life of the facility. }\end{array}$ \\
\hline $\begin{array}{l}\text { Sec. R(3), Disposal } \\
\text { Facility Monitoring } \\
\text { Plan }\end{array}$ & $\begin{array}{l}\text { With the performance assessment and composite analysis, a preliminary monitoring plan } \\
\text { must be submitted to Headquarters. The monitoring plan must be designed to measure and } \\
\text { evaluate releases, migration of radionuclides, disposal unit subsidence, and changes in } \\
\text { disposal facility and disposal site parameters which may affect long-term performance. }\end{array}$ \\
\hline
\end{tabular}




\section{Table 3.7 Minimum Topics To Be Covered In Waste Acceptance Criteria For DOE Low-Level Waste Facilities}

\begin{tabular}{|c|c|}
\hline $\begin{array}{c}\text { Section in } \\
\text { DOE M 435.1-1, } \\
\text { Chap. IV }\end{array}$ & Topic \\
\hline Sec. G(1)(a) & Allowable activity levels and/or concentrations of specific radionuclides. \\
\hline Sec. G(1)(b) & Acceptable waste form and/or container requirements. \\
\hline Sec. G(1)(c) & $\begin{array}{l}\text { Restrictions or prohibitions on waste, materials, or containers to prevent adverse effects on } \\
\text { workers or the facility. }\end{array}$ \\
\hline Sec. $G(1)(d)$ & $\begin{array}{l}\text { Waste specifications that: } \\
\text { - Minimize the need for long-term active maintenance; } \\
\text { - } \quad \text { Minimize contact of water with waste; } \\
\text { - } \quad \text { Reduce void spaces to the extent practical; } \\
\text { - } \quad \text { Require liquid waste or waste containing free liquid to be converted into a form } \\
\text { containing as little free standing liquid as reasonably achievable, and in no case } \\
\text { allowing liquid to exceed } 1 \text { percent of the waste volume in a disposal container, or } 0.5 \\
\text { percent of the volume of a stabilized waste. } \\
\text { - } \quad \text { Prohibit wastes capable of detonating or exploding at anticipated pressures and } \\
\text { - } \quad \text { Prohibit wastes capable of reacting explosively with water; } \\
\text { - } \quad \text { Require treatment to make pyrophoric materials nonflammable; } \\
\text { - } \quad \text { the facility, or the public; and } \\
\text { Limit pressure in gaseous waste packages to } 1.5 \text { atmospheres absolute at } 20^{\circ} \mathrm{C} \text {. }\end{array}$ \\
\hline Sec. G(1)(e) & Requirements for granting exceptions to waste acceptance criteria. \\
\hline
\end{tabular}

Table 3.8 Minimum Design Requirements for DOE Low-Level Waste Disposal Facilities

\begin{tabular}{|l|l|}
\hline $\begin{array}{c}\text { Section in } \\
\text { DOE M 435.1-1, } \\
\text { Chap. IV }\end{array}$ & \\
\hline Sec. M(3)(a) & Systems and components must confine the wastes. \\
\hline Sec. $\mathrm{M}(3)(\mathrm{b})(1)$ & $\begin{array}{l}\text { Ventilation system must filter releases to keep airborne radioactive effluents within applicable } \\
\text { limits. }\end{array}$ \\
\hline Sec. $\mathrm{M}(3)(\mathrm{b})(2)$ & Ventilation system must keep gases at non-flammable and non-explosive concentrations. \\
\hline Sec. $\mathrm{M}(3)(\mathrm{c})$ & $\begin{array}{l}\text { Structure must provide long-term stability and, to the extent practical, minimize maintenance } \\
\text { after final closure. }\end{array}$ \\
\hline Sec. $\mathrm{M}(3)(\mathrm{d})$ & To the extent practical, structure must minimize contact of waste with water. \\
\hline
\end{tabular}


Table 3.9 Performance Objectives for DOE-Regulated Low-Level Waste Disposal Facilities

\begin{tabular}{|l|l|}
\hline $\begin{array}{c}\text { Section in } \\
\text { DOE M 435.1-1, } \\
\text { Chap. IV }\end{array}$ & \multicolumn{1}{c|}{ Performance Objective } \\
\hline Sec. $\mathrm{P}(1)(\mathrm{a})$ & $\begin{array}{l}\text { Dose to representative members of the public shall not exceed } 25 \mathrm{mrem}(0.25 \mathrm{mSv}) \text { in a year } \\
\text { total effective dose equivalent from all exposure pathways, excluding the dose from radon } \\
\text { and its progeny in air. }\end{array}$ \\
\hline Sec. $\mathrm{P}(1)(\mathrm{b})$ & $\begin{array}{l}\text { Dose to representative members of the public via the air pathway shall not exceed } 10 \mathrm{mrem} \\
(0.10 \mathrm{mSv}) \text { in a year total effective dose equivalent, excluding the dose from radon and its } \\
\text { progeny. }\end{array}$ \\
\hline Sec. $\mathrm{P}(1)(\mathrm{c})$ & $\begin{array}{l}\text { Release of radon shall be less than an average flux of } 20 \mathrm{pCi} / \mathrm{m}^{2} / \mathrm{s}\left(0.74 \mathrm{~Bq} / \mathrm{m}^{2} / \mathrm{s}\right) \text { at the } \\
\text { surface of the disposal facility. Alternatively, a limit of } 0.5 \mathrm{pCi} / 1(0.0185 \mathrm{~Bq} / \mathrm{l}) \text { of air may } \\
\text { be applied at the boundary of the facility. }\end{array}$ \\
\hline
\end{tabular}


Table 4.1 Disposal Site Capacity and Costs for the Depleted Uranium Waste Form Options

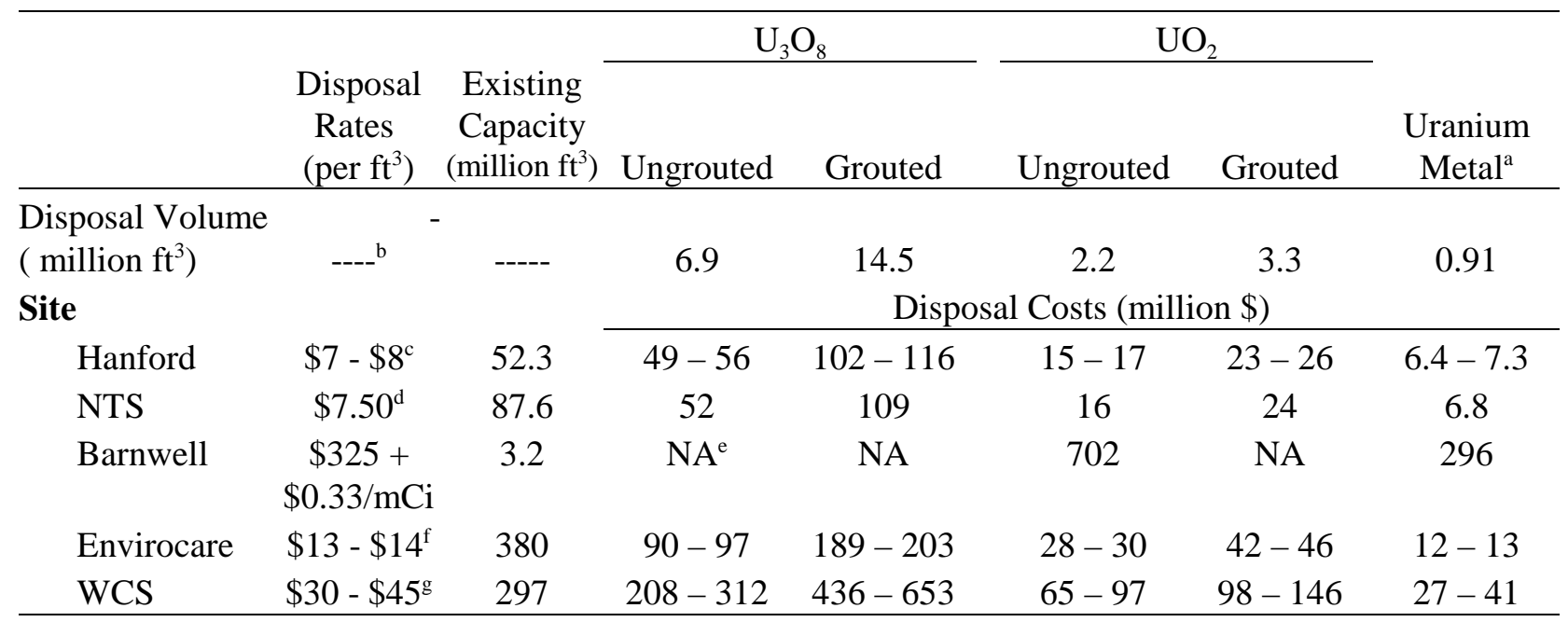

\footnotetext{
${ }^{a}$ Assumes that disposal of bulk depleted uranium metal is acceptable and thus no further treatment (e.g. grouting) is necessary. If uranium metal were packaged according to the engineering analysis report (LLNL 1997a), the disposal volume would be approximately 3.2 million $\mathrm{ft}^{3}$. In this case, disposal costs would be similar to those listed above for grouted $\mathrm{UO}_{2}$.

${ }^{\mathrm{b}}$ Not applicable.

${ }^{\mathrm{c}}$ Price is determined by the annual volume. A rough estimate for 100,000 to $200,000 \mathrm{ft}^{3}$ would be $\$ 7$ to $\$ 8$ per cubic foot (Garcia 1999). If it is determined that disposal in a HIC is necessary, a discounted price based on the same volume would be approximately $\$ 31$ per cubic foot (Blanchard 1999).

${ }^{\mathrm{d}}$ Price varies from year to year (Pyles 1999).

${ }^{\mathrm{e}}$ Not applicable, disposable volume exceeds capacity.

${ }^{\mathrm{f}}$ Loveland 1999b. Price is available to any DOE facility though a contract with the Ohio Operations Office.

${ }^{\mathrm{g}}$ Alford 1999.
} 


\section{Table 5.1 Annual Average Radiological Impacts to Involved}

\section{Workers ${ }^{\text {a }}$ from Disposal Options for Normal Operations}

\begin{tabular}{|c|c|c|c|c|}
\hline \multirow[b]{2}{*}{ Option/Location } & \multicolumn{2}{|c|}{ Dose } & \multicolumn{2}{|c|}{ Latent Cancer Risks } \\
\hline & $\begin{array}{c}\text { Average Dose } \\
(\mathrm{mrem} / \mathrm{yr})\end{array}$ & $\begin{array}{l}\text { Collective Dose } \\
\text { (person-rem/yr) }\end{array}$ & $\begin{array}{c}\text { Average Risk } \\
\text { (risk/yr) }\end{array}$ & $\begin{array}{c}\text { Collective Risk } \\
\text { (fatalities/yr) }\end{array}$ \\
\hline \multicolumn{5}{|l|}{ Disposal as Grouted $\mathrm{U}_{3} \mathrm{O}_{8}$} \\
\hline Shallow earthen structure & 290 & 24 & $1 \times 10^{-4}$ & $1 \times 10^{-2}$ \\
\hline Vault & 210 & 26 & $8 \times 10^{-5}$ & $1 \times 10^{-2}$ \\
\hline Mine & 410 & 36 & $2 \times 10^{-4}$ & $1 \times 10^{-2}$ \\
\hline \multicolumn{5}{|c|}{ Disposal as Ungrouted $\mathrm{U}_{3} \mathrm{O}_{8}$} \\
\hline Shallow earthen structure & 550 & 14 & $2 \times 10^{-4}$ & $6 \times 10^{-3}$ \\
\hline Vault & 330 & 15 & $1 \times 10^{-4}$ & $6 \times 10^{-3}$ \\
\hline Mine & 630 & 18 & $3 \times 10^{-4}$ & $7 \times 10^{-3}$ \\
\hline \multicolumn{5}{|l|}{ Disposal as Grouted $\mathrm{UO}_{2}$} \\
\hline Shallow earthen structure & 300 & 21 & $1 \times 10^{-4}$ & $8 \times 10^{-3}$ \\
\hline Vault & 300 & 22 & $1 \times 10^{-4}$ & $9 \times 10^{-3}$ \\
\hline Mine & 330 & 24 & $1 \times 10^{-4}$ & $1 \times 10^{-2}$ \\
\hline \multicolumn{5}{|l|}{ Disposal as Ungrouted $\mathrm{UO}_{2}$} \\
\hline Shallow earthen structure & 360 & 8.3 & $1 \times 10^{-4}$ & $3 \times 10^{-3}$ \\
\hline Vault & 430 & 11 & $2 \times 10^{-4}$ & $4 \times 10^{-3}$ \\
\hline Mine & 470 & 12 & $2 \times 10^{-4}$ & $5 \times 10^{-3}$ \\
\hline
\end{tabular}

a Involved workers are those workers directly involved with the handling of materials. Impacts are presented as average individual dose and collective dose for the worker population. Radiation doses to individual workers would be monitored by a dosimetry program and maintained below applicable standards, such as the DOE administrative control limit of 2,000 mrem/yr. 


\section{Table 5.2 Potential Impacts to Human Health from Physical Hazards under Accident} Conditions for the Disposal Options

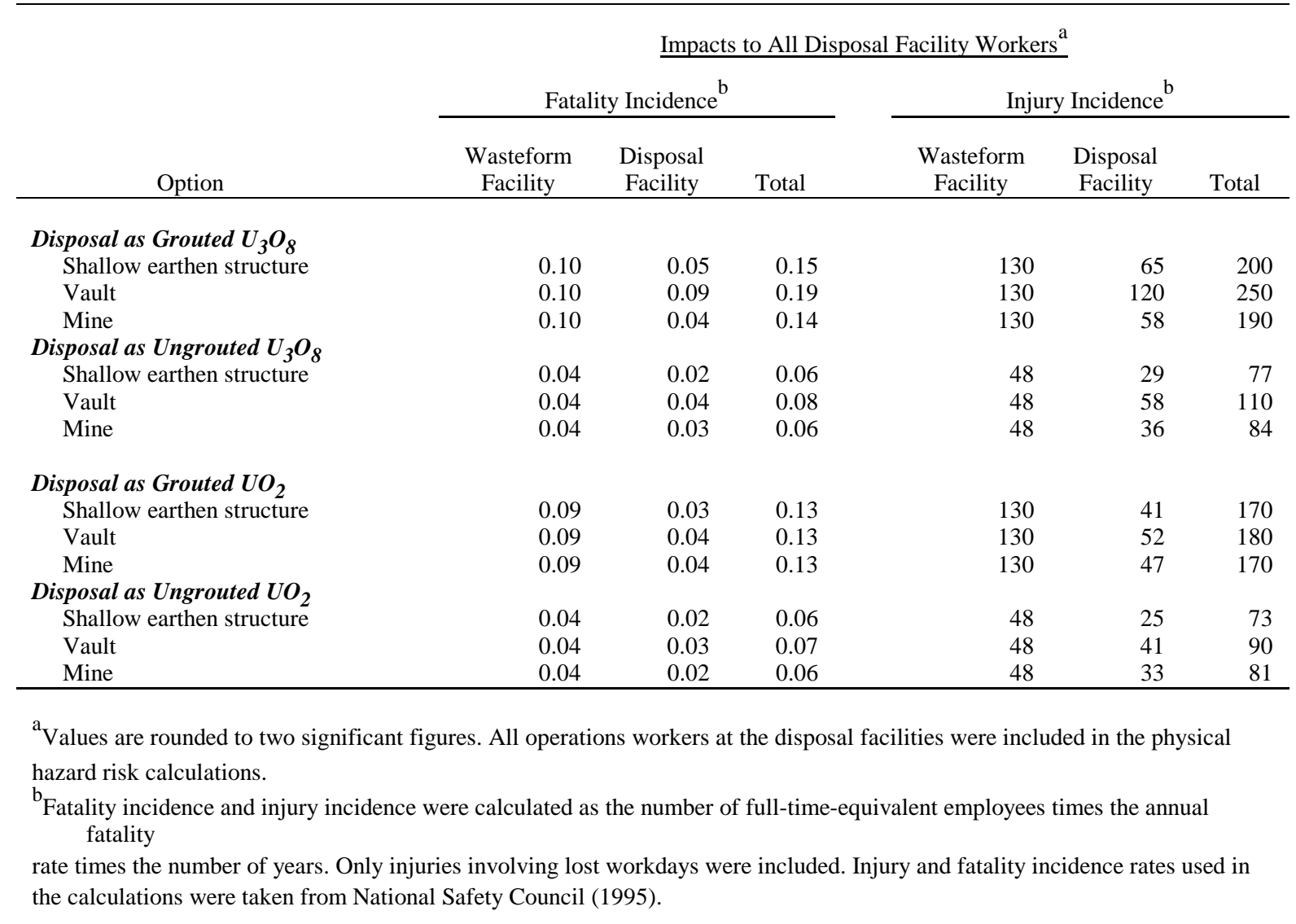


Table 5.3 Accidents Considered for the Disposal Options

\begin{tabular}{|c|c|c|c|}
\hline Option/Accident Scenario & Accident Description & $\begin{array}{c}\text { Duration } \\
(\min )\end{array}$ & $\begin{array}{l}\text { Release } \\
\text { Level }^{\mathrm{a}}\end{array}$ \\
\hline \multicolumn{4}{|c|}{ Likely Accidents (frequency: 1 or more times in 100 years) } \\
\hline $\begin{array}{l}\text { Mishandling/drop of } \\
\text { drum/billet inside the product } \\
\text { receiving area }\end{array}$ & $\begin{array}{l}\text { A single oxide drum is damaged by a forklift and spills } \\
\text { its contents onto the ground inside the product } \\
\text { receiving area. }\end{array}$ & Puff & Stack \\
\hline $\begin{array}{l}\text { Mishandling/drop of } \\
\text { drum/billet outside }\end{array}$ & $\begin{array}{l}\text { A single oxide drum is damaged by a forklift and spills } \\
\text { its contents outside without HEPA filtration. }\end{array}$ & Puff & Ground \\
\hline \multicolumn{4}{|c|}{ Unlikely Accidents (frequency: 1 in 100 years to 1 in 10,000 years) } \\
\hline Earthquake & $\begin{array}{l}\text { The product receiving area (and cement mixing area } \\
\text { for grout options) is damaged during a design-basis } \\
\text { earthquake, resulting in failure of the structure and } \\
\text { confinement systems. }\end{array}$ & Puff & Ground \\
\hline Tornado & $\begin{array}{l}\text { A major tornado and associated tornado missiles result } \\
\text { in failure of the product receiving area (and cement } \\
\text { mixing area structures for grout options) and } \\
\text { confinement systems. }\end{array}$ & Puff & Ground \\
\hline
\end{tabular}

Extremely Unlikely Accidents (frequency: 1 in 10,000 years to 1 in 1 million years), grout options only

$\begin{aligned} & \text { Fire/explosion inside the } \\ & \text { product mixing area }\end{aligned} \quad \begin{aligned} & \text { A fire or explosion within the product mixing area } \\ & \text { affects the contents of a single pallet of drums. }\end{aligned}$$\quad$ Puff $\quad$ Stack

Incredible Accidents (frequency: less than 1 in 1 million years)

Flood The facility would be located at a site that would $\quad$ NA NA preclude severe flooding.

${ }^{a}$ Ground-level releases were assumed to occur outdoors on concrete pads. To prevent contaminant migration, cleanup of residuals was assumed to begin immediately after the release was stopped.

Notation: HEPA = high-efficiency particulate air; NA = not applicable 


\section{Table 5.4 Estimated Radiological Doses per Accident Occurrence for the Disposal Options}

\begin{tabular}{|c|c|c|c|c|c|c|c|c|c|}
\hline \multirow[b]{3}{*}{ Option/Accident ${ }^{\mathrm{a}}$} & \multirow[b]{3}{*}{$\begin{array}{l}\text { Frequency } \\
\text { Category }\end{array}$} & \multicolumn{4}{|c|}{$\underline{\text { Maximum Dose }^{\mathrm{c}}}$} & \multicolumn{4}{|c|}{$\underline{\text { Minimum Dose }^{\mathrm{c}}}$} \\
\hline & & \multicolumn{2}{|c|}{ Noninvolved Workers } & \multicolumn{2}{|c|}{ General Public } & \multicolumn{2}{|c|}{ Noninvolved Workers } & \multicolumn{2}{|c|}{ General Public } \\
\hline & & $\begin{array}{l}\text { MEI } \\
(\mathrm{rem})\end{array}$ & $\begin{array}{c}\text { Population } \\
\text { (person-rem) }\end{array}$ & $\begin{array}{l}\text { MEI } \\
(\mathrm{rem})\end{array}$ & $\begin{array}{c}\text { Population } \\
\text { (person-rem) }\end{array}$ & $\begin{array}{l}\text { MEI } \\
(\mathrm{rem})\end{array}$ & $\begin{array}{c}\begin{array}{c}\text { Population } \\
\text { (person-rem) }\end{array} \\
\end{array}$ & $\begin{array}{l}\text { MEI } \\
(\mathrm{rem})\end{array}$ & $\begin{array}{c}\text { Population } \\
\text { (person-rem) }\end{array}$ \\
\hline \multicolumn{10}{|l|}{ Disposal as Grouted $U_{3} O_{8}$} \\
\hline Mishandling/drop of drum/billet outside & $\mathrm{L}$ & $4.1 \times 10^{-7}$ & $3.7 \times 10^{-8}$ & $1.3 \times 10^{-8}$ & $7.6 \times 10^{-8}$ & $4.1 \times 10^{-7}$ & $3.7 \times 10^{-8}$ & $1.0 \times 10^{-8}$ & $7.6 \times 10^{-8}$ \\
\hline Earthquake & $\mathrm{U}$ & $1.4 \times 10^{2}$ & 6.1 & 1.1 & 1.5 & $1.3 \times 10^{1}$ & 1.1 & $2.9 \times 10^{-1}$ & $8.7 \times 10^{-1}$ \\
\hline $\begin{array}{l}\text { Fire or explosion inside the product } \\
\text { Mixing area }\end{array}$ & $\mathrm{EU}$ & $5.5 \times 10^{-8}$ & $1.1 \times 10^{-7}$ & $5.7 \times 10^{-8}$ & $2.2 \times 10^{-6}$ & $1.6 \times 10^{-11}$ & $3.1 \times 10^{-11}$ & $2.8 \times 10^{-9}$ & $1.0 \times 10^{-6}$ \\
\hline $\begin{array}{l}\text { Disposal as Ungrouted } U_{3} O_{8} \\
\text { Mishandling/drop of drum inside the } \\
\text { Product receiving area }\end{array}$ & $\mathrm{L}$ & $9.0 \times 10^{-9}$ & $1.8 \times 10^{-8}$ & $9.3 \times 10^{-9}$ & $3.6 \times 10^{-7}$ & $2.7 \times 10^{-12}$ & $5.1 \times 10^{-12}$ & $4.6 \times 10^{-10}$ & $1.6 \times 10^{-7}$ \\
\hline Earthquake & $\mathrm{U}$ & $1.3 \times 10^{2}$ & 5.6 & 1.0 & 1.3 & $1.2 \times 10^{1}$ & $9.8 \times 10^{-1}$ & $2.7 \times 10^{-1}$ & $8.0 \times 10^{-1}$ \\
\hline \multicolumn{10}{|l|}{ Disposal as Grouted $\mathrm{UO}_{2}$} \\
\hline $\begin{array}{l}\text { Mishandling/drop of drum/billet outside } \\
\text { Earthquake }\end{array}$ & $\begin{array}{l}\mathrm{L} \\
\mathrm{U}\end{array}$ & $\begin{array}{l}9.8 \times 10 \\
2.7 \times 10^{-1}\end{array}$ & $\begin{array}{l}8.7 \times 10^{-2} \\
1.1 \times 10^{-2}\end{array}$ & $\begin{array}{l}3.0 \times 10^{-0} \\
2.1 \times 10^{-3}\end{array}$ & $\begin{array}{l}1.8 \times 10^{-7} \\
2.7 \times 10^{-3}\end{array}$ & $\begin{array}{l}9.8 \times 10^{-1} \\
2.4 \times 10^{-2}\end{array}$ & $\begin{array}{l}8.7 \times 10^{-0} \\
2.0 \times 10^{-3}\end{array}$ & $\begin{array}{l}2.4 \times 10^{-6} \\
5.5 \times 10^{-4}\end{array}$ & $\begin{array}{l}1.8 \times 10^{-7} \\
1.6 \times 10^{-3}\end{array}$ \\
\hline $\begin{array}{l}\text { Fire or explosion inside the product } \\
\text { Mixing area }\end{array}$ & EU & $2.3 \times 10^{-8}$ & $4.5 \times 10^{-8}$ & $2.4 \times 10^{-8}$ & $9.1 \times 10^{-7}$ & $6.8 \times 10^{-12}$ & $1.3 \times 10^{-11}$ & $1.2 \times 10^{-9}$ & $4.2 \times 10^{-7}$ \\
\hline $\begin{array}{l}\text { Disposal as Ungrouted } \mathrm{UO}_{2} \\
\text { Mishandling/drop of drum inside the } \\
\text { Product receiving area }\end{array}$ & $\mathrm{L}$ & $3.7 \times 10^{-9}$ & $7.3 \times 10^{-9}$ & $3.8 \times 10^{-9}$ & $1.5 \times 10^{-7}$ & $1.1 \times 10^{-12}$ & $2.1 \times 10^{-12}$ & $1.9 \times 10^{-10}$ & $6.7 \times 10^{-8}$ \\
\hline Earthquake & $\mathrm{U}$ & $2.2 \times 10^{-1}$ & $9.3 \times 10^{-3}$ & $1.7 \times 10^{-3}$ & $2.2 \times 10^{-3}$ & $1.9 \times 10^{-2}$ & $1.6 \times 10^{-3}$ & $4.4 \times 10^{-4}$ & $1.3 \times 10^{-3}$ \\
\hline
\end{tabular}

${ }^{\mathrm{a}}$ The bounding accident chosen to represent each frequency category is the one that would result in the highest dose to the general public MEI. Health impacts in that row represent that accident only and not the range of impacts among accidents in that category. Absence of an accident in a certain frequency category indicates that the accident would not result in a release of radioactive material.

${ }^{\mathrm{b}}$ Accident frequencies: likely (L), estimated to occur one or more times in 100 years of facility operations (> $\left.10^{-2} / \mathrm{yr}\right)$; unlikely (U), estimated to occur between once in 100 years and once in 10,000 years of facility operations $\left(10^{-2}-10^{-4} / \mathrm{yr}\right)$; extremely unlikely (EU), estimated to occur between once in 10,000 years and once in 1 million years of facility operations
$\left(10^{-4}-10^{-6} / \mathrm{yr}\right)$.

${ }^{\mathrm{c}}$ Maximum and minimum doses reflect differences in assumed sites, technologies, and meteorological conditions at the time of the accident. In general, maximum doses would occur under meteorological conditions of F stability with $1 \mathrm{~m} / \mathrm{s}$ wind speed, whereas minimum doses would occur under D stability with $4 \mathrm{~m} / \mathrm{s}$ wind speed. 


\section{Table 5.5 Estimated Radiological Health Risks per Accident Occurrence for the Disposal Options ${ }^{\mathrm{a}}$}

\begin{tabular}{|c|c|c|c|c|c|c|c|c|c|}
\hline \multirow[b]{3}{*}{ Option/Accident ${ }^{\mathrm{b}}$} & \multirow[b]{3}{*}{$\begin{array}{l}\text { Frequency } \\
\text { Category }\end{array}$} & \multicolumn{4}{|c|}{$\underline{\text { Maximum Risk }^{\mathrm{d}}(\mathrm{LCFs})}$} & \multicolumn{4}{|c|}{$\underline{\text { Minimum Risk }^{\mathrm{d}}(\mathrm{LCFs})}$} \\
\hline & & \multicolumn{2}{|c|}{ Noninvolved Workers } & \multicolumn{2}{|c|}{ General Public } & \multicolumn{2}{|c|}{ Noninvolved Workers } & \multicolumn{2}{|c|}{ General Public } \\
\hline & & MEI & Population & MEI & Population & MEI & Population & MEI & Population \\
\hline \multicolumn{10}{|l|}{ Disposal as Grouted $U_{3} O_{8}$} \\
\hline Mishandling/drop of drum/billet outside & $\mathrm{L}$ & $2 \times 10_{-2}^{-10}$ & $1 \times 10^{-11}$ & $6 \times 10^{-12}$ & $4 \times 10^{-11}$ & $2 \times 10^{-10}$ & $1 \times 10^{-11}$ & $5 \times 10^{-12}$ & $4 \times 10^{-11}$ \\
\hline Earthquake & $\mathrm{U}$ & $6 \times 10^{-2}$ & $2 \times 10^{-3}$ & $5 \times 10^{-4}$ & $7 \times 10^{-4}$ & $5 \times 10^{-3}$ & $4 \times 10^{-4}$ & $1 \times 10^{-4}$ & $4 \times 10^{-4}$ \\
\hline $\begin{array}{l}\text { Fire or explosion inside the product } \\
\text { Mixing area }\end{array}$ & $\mathrm{EU}$ & $2 \times 10^{-11}$ & $4 \times 10^{-11}$ & $3 \times 10^{-11}$ & $1 \times 10^{-9}$ & $7 \times 10^{-15}$ & $1 \times 10^{-14}$ & $1 \times 10^{-12}$ & $5 \times 10^{-10}$ \\
\hline $\begin{array}{l}\text { Disposal as Ungrouted } \mathrm{U}_{3} \mathrm{O}_{8} \\
\text { Mishandling/drop of drum inside the } \\
\text { Product receiving area }\end{array}$ & $\mathrm{L}$ & $4 \times 10^{-12}$ & $7 \times 10^{-12}$ & $5 \times 10^{-12}$ & $2 \times 10^{-10}$ & $1 \times 10^{-15}$ & $2 \times 10^{-15}$ & $2 \times 10^{-13}$ & $8 \times 10^{-11}$ \\
\hline Earthquake & $\mathrm{U}$ & $5 \times 10^{-2}$ & $2 \times 10^{-3}$ & $5 \times 10^{-4}$ & $7 \times 10^{-4}$ & $5 \times 10^{-3}$ & $4 \times 10^{-4}$ & $1 \times 10^{-4}$ & $4 \times 10^{-4}$ \\
\hline \multicolumn{10}{|l|}{ Disposal as Grouted $\mathrm{UO}_{2}$} \\
\hline $\begin{array}{l}\text { Mishandling/drop of drum/billet outside } \\
\text { Earthquake }\end{array}$ & $\begin{array}{l}\mathrm{L} \\
\mathrm{U}\end{array}$ & $\begin{array}{l}4 \times 10 \\
1 \times 10^{-4}\end{array}$ & $\begin{array}{l}3 \times 10 \\
5 \times 10^{-6}\end{array}$ & $\begin{array}{l}1 \times 10 \\
1 \times 10^{-6}\end{array}$ & $\begin{array}{l}9 \times 10 \\
1 \times 10^{-6}\end{array}$ & $\begin{array}{l}4 \times 10 \\
1 \times 10^{-5}\end{array}$ & $\begin{array}{l}3 \times 10 \\
8 \times 10^{-7}\end{array}$ & $\begin{array}{l}1 \times 10 \\
3 \times 10^{-7}\end{array}$ & $\begin{array}{l}9 \times 10 \\
8 \times 10^{-7}\end{array}$ \\
\hline $\begin{array}{l}\text { Fire or explosion inside the product } \\
\text { Mixing area }\end{array}$ & EU & $9 \times 10^{-12}$ & $2 \times 10^{-11}$ & $1 \times 10^{-11}$ & $5 \times 10^{-10}$ & $3 \times 10^{-15}$ & $5 \times 10^{-15}$ & $6 \times 10^{-13}$ & $2 \times 10^{-10}$ \\
\hline $\begin{array}{l}\text { Disposal as Ungrouted } \mathrm{UO}_{2} \\
\text { Mishandling/drop of drum inside the } \\
\text { Product receiving area }\end{array}$ & $\mathrm{L}$ & $1 \times 10^{-12}$ & $3 \times 10^{-12}$ & $2 \times 10^{-12}$ & $7 \times 10^{-11}$ & $4 \times 10^{-16}$ & $8 \times 10^{-16}$ & $9 \times 10^{-14}$ & $3 \times 10^{-11}$ \\
\hline Earthquake & $\mathrm{U}$ & $9 \times 10^{-5}$ & $4 \times 10^{-6}$ & $8 \times 10^{-7}$ & $1 \times 10^{-6}$ & $8 \times 10^{-6}$ & $7 \times 10^{-7}$ & $2 \times 10^{-7}$ & $7 \times 10^{-7}$ \\
\hline
\end{tabular}

${ }^{a}$ Values shown are the consequences if the accident did occur. The risk of an accident is the consequence (LCF) times the estimated frequency times 26 years of operations. The estimated frequencies are as follows: likely (L), 0.1; unlikely (U), 0.001; extremely unlikely (EU), 0.00001; incredible (I), 0.000001.

${ }^{b}$ The bounding accident chosen to represent each frequency category is the one that would result in the highest risk to the general public MEI. Health impacts in that row represent that accident only and not the range of impacts among accidents in that category. Absence of an accident in a certain frequency category indicates that the accident would not result in a release of radioactive material.

${ }^{\mathrm{c}}$ Accident frequencies: likely (L), estimated to occur one or more times in 100 years of facility operations (> 10-2/yr); unlikely (U), estimated to occur between once in 100 years and once in 10,000 years of facility operations $\left(10^{-2}-10^{-4} / \mathrm{yr}\right.$ ); extremely unlikely (EU), estimated to occur between once in 10,000 years and once in 1 million years of facility operations $\left(10^{-4}-10^{-6} / \mathrm{yr}\right)$.

${ }^{\mathrm{d}}$ Maximum and minimum risks reflect differences in assumed sites, technologies, and meteorological conditions at the time of the accident. In general, maximum risks would occur under meteorological conditions of F stability with $1 \mathrm{~m} / \mathrm{s}$ wind speed, whereas minimum risks would occur under D stability with $4 \mathrm{~m} / \mathrm{s}$ wind speed. 


\section{Table 5.6 Number of Persons with Potential for Adverse Effects from Accidents under the Disposal Options ${ }^{\mathrm{a}}$}

\begin{tabular}{|c|c|c|c|c|c|c|c|c|c|}
\hline \multirow[b]{3}{*}{ Option/Accident ${ }^{\mathrm{b}}$} & \multirow{3}{*}{$\begin{array}{l}\text { Frequency } \\
\text { Category }\end{array}$} & \multicolumn{4}{|c|}{$\underline{\text { Maximum Number of Persons }}{ }^{\mathrm{d}}$} & \multicolumn{4}{|c|}{$\underline{\text { Minimum Number of Persons }}{ }^{\mathrm{d}}$} \\
\hline & & \multicolumn{2}{|c|}{ Noninvolved Workers } & \multicolumn{2}{|c|}{ General Public } & \multicolumn{2}{|c|}{ Noninvolved Workers } & \multicolumn{2}{|c|}{ General Public } \\
\hline & & $\mathrm{MEI}^{\mathrm{e}}$ & Population & MEI $^{\mathrm{e}}$ & Population & $\mathrm{MEI}^{\mathrm{e}}$ & Population & $\mathrm{MEI}^{\mathrm{e}}$ & Population \\
\hline $\begin{array}{l}\text { Disposal as Grouted } U_{3} O_{8} \\
\text { Mishandle/drop of drum/billet outside } \\
\text { Earthquake } \\
\text { Fire/explosion inside }\end{array}$ & $\begin{array}{c}\mathrm{L} \\
\mathrm{U} \\
\mathrm{EU}\end{array}$ & $\begin{array}{l}\text { No } \\
\text { Yes } \\
\text { No }\end{array}$ & $\begin{array}{l}0 \\
1 \\
0\end{array}$ & $\begin{array}{l}\mathrm{No}_{\mathrm{g}} \\
\mathrm{Yes}^{\mathrm{No}}\end{array}$ & $\begin{array}{l}0 \\
0 \\
0\end{array}$ & $\begin{array}{l}\text { No } \\
\text { Yes } \\
\text { No }\end{array}$ & $\begin{array}{l}0 \\
1 \\
0\end{array}$ & $\begin{array}{l}\text { No } \\
\text { No } \\
\text { No }\end{array}$ & $\begin{array}{l}0 \\
0 \\
0\end{array}$ \\
\hline $\begin{array}{l}\text { Disposal as Grouted } \boldsymbol{U O}_{2} \\
\text { Mishandle/drop of drum/billet outside } \\
\text { Earthquake } \\
\text { Fire/explosion inside } \\
\text { f }\end{array}$ & $\begin{array}{c}\mathrm{L} \\
\mathrm{U} \\
\mathrm{EU}\end{array}$ & $\begin{array}{l}\text { No } \\
\text { No } \\
\text { No }\end{array}$ & $\begin{array}{l}0 \\
0 \\
0 \\
\end{array}$ & $\begin{array}{l}\text { No } \\
\text { No } \\
\text { No }\end{array}$ & $\begin{array}{l}0 \\
0 \\
0 \\
\end{array}$ & $\begin{array}{l}\text { No } \\
\text { No } \\
\text { No } \\
\end{array}$ & $\begin{array}{l}0 \\
0 \\
0 \\
\end{array}$ & $\begin{array}{l}\text { No } \\
\text { No } \\
\text { No } \\
\end{array}$ & $\begin{array}{l}0 \\
0 \\
0 \\
\end{array}$ \\
\hline \multicolumn{10}{|c|}{${ }^{a}$ Values shown are the consequences if the accident did occur. The risk of an accident is the consequence (number of persons) times the estimated frequency times } \\
\hline \multicolumn{10}{|c|}{$\begin{array}{l}26 \text { years of operations. The estimated frequencies are as follows: likely }(\mathrm{L}), 0.1 \text {; unlikely }(\mathrm{U}), 0.001 \text {; extremely unlikely }(\mathrm{EU}), 0.00001 ; \text { incredible (I), } 0.000001 . \\
\mathrm{b}_{\text {The bounding accident chosen to represent each frequency category is the one in which the largest number of people (noninvolved workers plus off-site people) }}\end{array}$} \\
\hline \multicolumn{10}{|c|}{ would be affected. Health impacts in that row represent that accident only and not the range of impacts among accidents in that category. } \\
\hline \multicolumn{10}{|c|}{${ }^{\mathrm{c}}$ Accident frequencies: likely (L), estimated to occur one or more times in 100 years of facility operations (> $\left.10^{-2} / \mathrm{yr}\right)$; unlikely (U), estimated to occur between once } \\
\hline \multicolumn{10}{|c|}{$\begin{array}{l}1 \text { million years of facility operations }\left(10^{-4}-10^{-6} / \mathrm{yr}\right) \text {; incredible }(\mathrm{I}) \text {, estimated to occur less than one time in } 1 \text { million years of facility operations }\left(<10^{-6} / \mathrm{yr}\right) \text {. } \\
{ }^{\mathrm{d}} \text { Maximum and minimum risks reflect different meteorological conditions at the time of the accident. In general, maximum risks would occur under }\end{array}$} \\
\hline \multicolumn{10}{|c|}{ meteorological conditions of F stability with $1 \mathrm{~m} / \mathrm{s}$ wind speed, whereas minimum risks would occur under D stability with $4 \mathrm{~m} / \mathrm{s}$ wind speed. } \\
\hline \multicolumn{10}{|c|}{ eAt the MEI location, the determination is either "Yes" or "No" for potential adverse effects to an individual. } \\
\hline \multicolumn{10}{|c|}{ f These accidents would result in the largest plume sizes, although no people would be affected. } \\
\hline
\end{tabular}


Table 5.7 Human Health Impacts for the MEI from Disposal Options: Post-Closure Phase

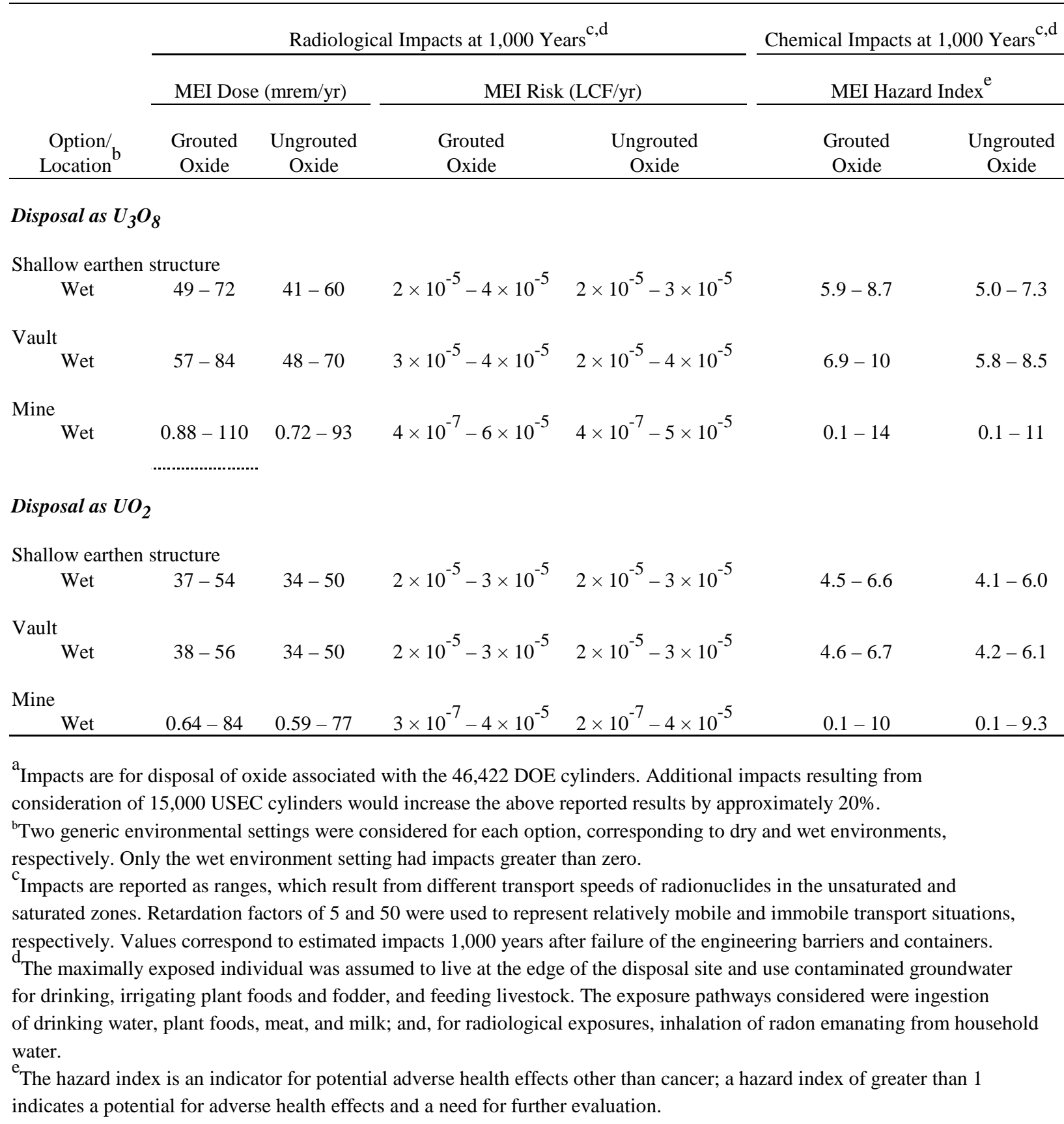


Table 6.1 Maximum Annual Average Uranium

Concentrations in Air during Operation of the

Wasteform Facility for Disposal of Grouted

Uranium Oxide

\begin{tabular}{cc}
\hline Site Environment/ & $\begin{array}{c}\text { Maximum Annual Average } \\
\text { Uranium Concentration } \\
\left(\mathrm{g} / \mathrm{m}^{3}\right)\end{array}$ \\
\hline Receptor Distance & \\
Disposal as Grouted $\boldsymbol{U O}_{2}$ & \\
Dry setting & \\
$750 \mathrm{~m}$ & $1.7 \times 10^{-5}-3.0 \times 10^{-5}$ \\
$1,000 \mathrm{~m}$ & $1.2 \times 10^{-5}-2.1 \times 10^{-5}$ \\
$1,500 \mathrm{~m}$ & $0.71 \times 10^{-5}-1.3 \times 10^{-5}$ \\
& \\
Wet setting & $1.8 \times 10^{-5}-2.7 \times 10^{-5}$ \\
$750 \mathrm{~m}$ & $1.2 \times 10^{-5}-2.0 \times 10^{-5}$ \\
$1,000 \mathrm{~m}$ & $0.76 \times 10^{-5}-1.3 \times 10^{-5}$ \\
$1,500 \mathrm{~m}$ & \\
& \\
Disposal as Grouted $\boldsymbol{U}_{3} \boldsymbol{O}_{\boldsymbol{8}}$ & \\
& \\
Dry setting & \\
$750 \mathrm{~m}$ & \\
$1,000 \mathrm{~m}$ & $0.94 \times 10^{-5}-1.6 \times 10^{-5}$ \\
$1,500 \mathrm{~m}$ & $0.66 \times 10^{-5}-1.2 \times 10^{-5}$ \\
& $0.39 \times 10^{-5}-0.72 \times 10^{-5}$ \\
Wet setting & \\
$750 \mathrm{~m}$ & \\
$1,000 \mathrm{~m}$ & $0.96 \times 10^{-5}-1.5 \times 10^{-5}$ \\
$1,500 \mathrm{~m}$ & $0.48 \times 10^{-5}-1.1 \times 10^{-5}$ \\
&
\end{tabular}


Table 6.2 Summary of Water Parameters for the Disposal Facility During the Operational Phase

\begin{tabular}{|c|c|c|c|c|c|}
\hline \multirow[b]{2}{*}{ Facility/Parameter } & \multirow[b]{2}{*}{ Unit } & \multicolumn{2}{|c|}{$\underline{\text { Disposal as U }}_{3} \underline{\mathrm{O}}_{8}$} & \multicolumn{2}{|c|}{${\underline{\text { Disposal as } \mathrm{UO}_{2}}}_{2}$} \\
\hline & & Grouted & Ungrouted & Grouted & Ungrouted \\
\hline \multicolumn{6}{|l|}{ Wasteform Facility } \\
\hline Water Use & million gal/yr & 19.4 & 0.1 & 8.2 & 0.1 \\
\hline Wastewater & million gal/yr & 1.1 & 0.1 & 0.6 & 0.1 \\
\hline \multicolumn{6}{|c|}{ Shallow Earthen Structure } \\
\hline Water Use & million gal/yr & 0.02 & 0.01 & 0.01 & 0.01 \\
\hline Wastewater & million $\mathrm{gal} / \mathrm{yr}$ & 0.005 & 0.005 & 0.003 & 0.003 \\
\hline \multicolumn{6}{|l|}{ Vault } \\
\hline Water Use & million gal/yr & 0.05 & 0.02 & 0.02 & 0.01 \\
\hline Wastewater & million $\mathrm{gal} / \mathrm{yr}$ & 0.05 & 0.02 & 0.02 & 0.01 \\
\hline \multicolumn{6}{|l|}{ Mine } \\
\hline Water Use & million gal/yr & 0.9 & 0.6 & 0.5 & 0.4 \\
\hline Wastewater & million $\mathrm{gal} / \mathrm{yr}$ & 0.2 & 0.1 & 0.08 & 0.07 \\
\hline
\end{tabular}


Table 6.3 Potential Radiological and Chemical Impacts to Aquatic Biota due to Failure of a Disposal Facility

\begin{tabular}{|c|c|c|c|}
\hline \multirow[b]{2}{*}{ Option/Contaminant } & \multirow[b]{2}{*}{ Maximum Exposure } & \multicolumn{2}{|c|}{ Effect } \\
\hline & & Radiological & Chemical \\
\hline Disposal as $U_{3} O_{8}$ & & & \\
\hline $\begin{array}{l}\text { Shallow earthen structure } \\
\text { Uranium in groundwater }\end{array}$ & $\begin{array}{l}2.0 \text { to } 270 \mathrm{pCi} / \mathrm{L} \\
\left(3.1 \times 10^{-6} \text { to } 1.1 \times 10^{-3} \mathrm{~g} / \mathrm{L}\right)\end{array}$ & Negligible & Moderate \\
\hline $\begin{array}{l}\text { Vault } \\
\text { Uranium in groundwater }\end{array}$ & $\begin{array}{l}2.4 \text { to } 315 \mathrm{pCi} / \mathrm{L} \\
\left(9.7 \times 10^{-6} \text { to } 1.3 \times 10^{-3} \mathrm{~g} / \mathrm{L}\right)\end{array}$ & Negligible & Moderate \\
\hline $\begin{array}{l}\text { Mine } \\
\text { Uranium in groundwater }\end{array}$ & $\begin{array}{l}0 \text { to } 425 \mathrm{pCi} / \mathrm{L} \\
\left(0 \text { to } 1.7 \times 10^{-3} \mathrm{~g} / \mathrm{L} \text { ) }\right.\end{array}$ & Negligible & $\begin{array}{l}\text { Negligible } \\
\text { to moderate }\end{array}$ \\
\hline
\end{tabular}

\section{Disposal as $\mathrm{UO}_{2}$}

Shallow earthen structure

Uranium in groundwater

1.7 to $204 \mathrm{pCi} / \mathrm{L}$
$\left(6.9 \times 10^{-6}\right.$ to $\left.8.2 \times 10^{-4} \mathrm{~g} / \mathrm{L}\right)$

Negligible Moderate

Vault

Uranium in groundwater

1.7 to $209 \mathrm{pCi} / \mathrm{L}$
$\left(6.9 \times 10^{-6}\right.$ to $\left.8.4 \times 10^{-4} \mathrm{~g} / \mathrm{L}\right)$

Negligible Moderate

Mine

Uranium in groundwater

0 to $316 \mathrm{pCi} / \mathrm{L}$

Negligible

Negligible

$\left(0\right.$ to $\left.1.3 \times 10^{-3} \mathrm{~g} / \mathrm{L}\right)$

to moderate

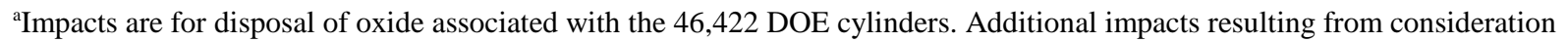
of 15,000 USEC cylinders would increase uranium concentrations approximately $20 \%$. The overall ecological impacts are expected to remain the same (DOE 1999). 


\section{APPENDIX A}

\section{Analysis of Whether DePleted UraniUm in OXIDE OR Metal Form Would Be Source MATerial, BY-Product Material or SPECIAl NuClear MATERIAL}

\section{A.1 Description of DOE's Depleted Uranium Inventory}

DOE's inventory of depleted uranium exists essentially in the form of pure chemical compounds. The majority (greater than 95 percent) is depleted $\mathrm{UF}_{6} . \mathrm{UO}_{3}$ represents most of the non$\mathrm{UF}_{6}$ depleted uranium, amounting to around 3 percent of the DOE inventory. About one percent is depleted uranium metal, and the remainder is $\mathrm{UF}_{4}$. For the purpose of this report, it is assumed that all of DOE's depleted uranium inventory will be converted either to an oxide form of uranium (i.e., $\mathrm{U}_{3} \mathrm{O}_{8}$ or $\mathrm{UO}_{2}$ ) or to uranium metal before disposal.

The analyses presented below consider whether depleted uranium would be source material, special nuclear material, or byproduct material, as defined by the Atomic Energy Act of 1954 (AEA) [Pub. L. 83-703; 68 Stat. 919], as amended.

\section{A.2 Byproduct Material}

\section{A.2.1 Definition}

The term "by-product material" has two meanings under the Atomic Energy Act:

(1) Any radioactive material (except special nuclear material) yielded in or made radioactive by exposure to the radiation incident to the process of producing or utilizing special nuclear material (referred to as $\S 11(\mathrm{e})(1)$ byproduct material) [AEA $\S 11(\mathrm{e})(1) ; 42$ U.S.C. $\S 2014(\mathrm{e})(1)]$; and

(2) The tailings or wastes produced by the extraction or concentration of uranium or thorium from any ore processed primarily for its source material content (referred to as uranium or thorium tailings and waste, or $\S 11(\mathrm{e})(2)$ byproduct material) [AEA $\S 11(\mathrm{e})(2) ; 42$ U.S.C. $\S 2014(\mathrm{e})(2)]$.

Both DOE [DOE M 435.1-1, Attachment 2, item 2] and NRC [40 CFR 30.4 and 40 CFR 40.4] have adopted these definitions of byproduct material. However, the NRC definition of $\S 11(\mathrm{e})(2)$ byproduct material clarifies that byproduct material includes discrete surface wastes resulting from uranium solution extraction processes [40 CFR 40.4]. 


\section{A.2.2 Analysis}

Based on the plain language of the definition, an argument could be made that depleted uranium should be regulated as byproduct material because it is not special nuclear material, and it is a radioactive material yielded in the process of producing uranium-235, which is special nuclear material. However, the AEC (now NRC and DOE) long ago classified depleted uranium as source material rather than byproduct material. For example, the requirement for labeling exempt counterweights to indicate they contain depleted uranium has been in 10 CFR $\$ 40.13$ (c) since at least 1969 [see 10 CFR 40.13(c)(ii), footnote 2]. Furthermore, during the licensing hearings for the Claiborne Enrichment Center, the NRC staff argued, and the Atomic Safety and Licensing Board accepted, that depleted uranium hexafluoride produced by the proposed uranium enrichment facility would be source material under the definition in 10 CFR \$40.4 [In the Matter of Louisiana Energy Services, L.P. (Claiborne Enrichment Center), 34 N.R.C. 332, LBP-91-41 (December 19, 1991)]. DOE has also adopted the AEC view that depleted uranium should be classified as source material [see DOE Oak Ridge Operations Office, Letter from J. La Grone, Manager, to Ohio EPA (R. Shank, Director) (October 29, 1990) (arguing that the cylinders of depleted uranium at the Portsmouth Gaseous Diffusion Plant are source material under the Atomic Energy Act)]. Therefore, depleted uranium should not be classified as byproduct material under the Atomic Energy Act definition because the agencies primarily responsible for interpreting the Act have concluded otherwise.

Depleted uranium also is not $\S 11(\mathrm{e})(2)$ byproduct material, because it is not waste or tailings produced by the extraction or concentration of uranium or thorium from ore. On the contrary, depleted uranium is material extracted from uranium ore. Therefore, depleted uranium does not match the definition of $\S 11(\mathrm{e})(2)$ byproduct material.

\section{A.3 Source Material}

\section{A.3.1 Definition}

The AEA defines "source material" as uranium, thorium, or ores containing these materials in concentrations to be specified in regulations promulgated by the Atomic Energy Commission [42 U.S.C. $\$ 2014(z)$ ], which was the predecessor agency of the Nuclear Regulatory Commission (NRC) and the Department of Energy (DOE). The Atomic Energy Commission adopted regulations defining the term "source material" as: (1) uranium or thorium, or any combination thereof, in any physical or chemical form, or (2) ores which contain by weight one-twentieth of one percent $(0.05 \%)$ or more of: (i) uranium, (ii) thorium, or (iii) any combination thereof. However, any material that would be special nuclear material was excluded. The NRC and DOE have adopted this definition in 10 CFR Part 40, "Domestic Licensing of Source Material" [10 CFR §40.4], and DOE M 435.1-1, "Radioactive Waste Management Manual," Attachment 2, item 42 , respectively. 


\section{A.3.2 Analysis}

As was explained in section A1.2, the AEC and its successor agencies have determined that depleted uranium and depleted uranium compounds fall within the first component of the definition of source material because such materials are chemical forms of uranium. Therefore, depleted uranium should be classified as source material.

\section{A.4 Special Nuclear Material (SNM)}

\section{A.4.1 Definition}

The AEA defines the term "special nuclear material" as: (1) plutonium, uranium enriched in the isotope 233 or in the isotope 235, and any other material which the Atomic Energy Commission determines, pursuant to section 51 of the AEA to be special nuclear material, but does not include source material; or (2) any material artificially enriched by any of the foregoing, but does not include source material. [42 U.S.C. §2014(aa)] Section 51 authorizes the Atomic Energy Commission (predecessor agency of the NRC and DOE) to name materials that meet certain criteria as special nuclear material, upon receiving the express written assent of the President. NRC and DOE have both adopted, without modification, the AEA definition of special nuclear material. [10 CFR §70.4 and DOE M 435.1-1, Attachment 2, item 43, respectively]

\section{A.4.2 Analysis}

As source material (see section A2.2, above), depleted uranium is excluded from the definition of special nuclear material. However, even if it were not excluded, depleted uranium, regardless of its chemical or physical form, is not plutonium. Further, depleted uranium contains less than the naturally occurring concentration of the isotope 235 , not more. Therefore, it is not enriched in the isotope 235. It also is not enriched in the isotope 233, which does not occur in the natural uranium feed to the uranium enrichment process, and is not produced by that process. Finally, no depleted uranium in DOE's present inventory has been processed in any way that would cause it to be artificially enriched with plutonium, U-233 or U-235. Therefore, depleted uranium, regardless of its physical or chemical form, is not special nuclear material.

\section{A.5 Conclusion}

Based on the analyses presented above, depleted uranium should be classified as source material under the Atomic Energy Act. 


\section{APPENDIX B}

\section{ANALYSIS OF WHETHER DISCARDED DEPLETED URANIUM IN Oxide Or Metal Form Would Be High-Level Waste, SPENT Nuclear Fuel, Transuranic Waste, or LoW-LEVEL WASTE}

Regulatory requirements applicable to disposal of a discarded radioactive material are dictated by the category of radioactive waste into which the material falls. The Nuclear Waste Policy Act of 1982 (NWPA) [Pub. L. 97-425; 96 Stat. 2201; 42 U.S.C. $\$ 10101-10270]$ and the Low-Level Radioactive Waste Policy Amendments Act of 1985 (LLWPAA) [Pub. L. 99-240; 99 Stat. 1842; 42 U.S.C. $\S \S 2021$ b - 2021i] define four categories of radioactive waste, which include high-level radioactive waste, spent nuclear fuel, transuranic waste and low-level radioactive waste. Byproduct material defined by the AEA $\S 11(\mathrm{e})(2)$ (i.e., uranium and thorium mill tailings) is also a category of radioactive waste. However, an analysis of whether depleted uranium oxides or metal would qualify as AEA byproduct material was presented in Appendix A. That analysis demonstrates that depleted uranium in neither oxide nor metal form qualifies as AEA $\$ 11(\mathrm{e})(2)$ byproduct material. Therefore, that analysis is not repeated in this appendix.

\section{B.1 High-level Radioactive Waste}

\section{B.1.1 Definition}

The term "high-level radioactive waste" is defined by the NWPA to mean:

(1) the highly radioactive waste material resulting from the reprocessing of spent nuclear fuel, including liquid waste produced directly in reprocessing and any solid waste derived from such liquid, that contains fission products in sufficient concentrations; and

(2) other highly radioactive material that the Nuclear Regulatory Commission, consistent with existing law, determines by rule requires permanent isolation. [42 U.S.C. §10101(12)]

The Nuclear Regulatory Commission defines high-level waste for identifying materials that are to be disposed of in a geologic repository as follows:

High-level radioactive waste means: (1) irradiated reactor fuel, (2) liquid wastes resulting from the operation of the first cycle solvent extraction system, or equivalent, and the concentrated wastes from subsequent extraction cycles, or equivalent, in a facility for reprocessing irradiated reactor fuel, and (3) solids into which such liquid wastes have been converted. [10 CFR §60.2]

DOE defines high-level waste using the definition contained in the NWPA. [DOE M 435.1-1, Attachment 2, item 22]

\section{B.1.2 Analysis}

No form of depleted uranium is irradiated reactor fuel, or results from the reprocessing of spent nuclear fuel. In addition, neither the NRC nor DOE has determined that any form of depleted 
uranium requires permanent isolation. Therefore, neither depleted uranium oxides nor depleted uranium metal should be characterized as high-level radioactive waste for disposal.

\section{B.2 Spent Nuclear Fuel}

\section{B.2.1 Definition}

The NWPA defines "spent nuclear fuel" as fuel that has been withdrawn from a nuclear reactor following irradiation, but that has not been reprocessed to remove its constituent elements. [42 U.S.C. $\S 10101(23)]$

NRC regulations include irradiated reactor fuel within the definition of high-level radioactive waste, and contain no separate definition for spent nuclear fuel. DOE defines spent nuclear fuel using the definition contained in the NWPA.” [DOE M 435.1-1, Attachment 2, item 44]

\section{B.2.2 Analysis}

No form of depleted uranium has been manufactured into nuclear fuel or irradiated in a nuclear reactor. Therefore, no form of depleted uranium should be characterized as spent nuclear fuel for disposal.

\section{B.3 Transuranic Waste}

\section{B.3.1 Definition}

The AEA defines "transuranic waste" as material contaminated with elements that have an atomic number greater than 92, including neptunium, plutonium, americium, and curium, and that are in concentrations greater than 10 nanocuries per gram, or in such other concentrations as the NRC may prescribe to protect the public health and safety. [ 42 U.S.C. $\$ 2014(\mathrm{ee})$ ]

The Waste Isolation Pilot Project Land Withdrawal Act of 1992, on the other hand, defines transuranic waste as radioactive waste containing more than 100 nanocuries (3700 becquerels) of alpha-emitting transuranic isotopes per gram of waste, with half-lives greater than 20 years, except for: (1) high-level radioactive waste; (2) waste that the Secretary of Energy has determined, with the concurrence of the Administrator of the EPA, does not need the degree of isolation required by the 40 CFR Part 191 disposal regulations; or (3) waste that the NRC has approved for disposal on a caseby-case basis in accordance with 10 CFR Part 61.

The NRC has adopted no regulations specifically defining the term "transuranic waste." DOE defines transuranic waste using the definition contained in the Waste Isolation Pilot Project Land Withdrawal Act of 1992. [DOE M 435.1-1, Attachment 2, item 49]

\section{B-3.2 Analysis}

Neither depleted uranium in oxide form nor depleted uranium metal derived from DOE's inventory of depleted uranium will contain alpha-emitting transuranic isotopes. Therefore, regardless of which 
definition stated above is used, neither depleted uranium oxides nor depleted uranium metal should be characterized as transuranic waste for disposal.

\section{B.4 Low-level Radioactive Waste}

\section{B.4.1 Definition}

The term "low-level waste" is defined by the LLWPAA as radioactive material that (A) is not highlevel radioactive waste, spent nuclear fuel, or byproduct material (as defined in section 11(e)(2) of the AEA); and (B) the NRC, consistent with existing law and in accordance with paragraph (A), classifies as low-level radioactive waste. [42 U.S.C. §2021b(9)] The NRC adopts this definition in 10 CFR Part 61, "Licensing Requirement for Land Disposal of Radioactive Waste." [10 CFR §61.2] DOE has also adopted this definition, but in addition, the DOE definition excludes naturally occurring radioactive material from the radioactive materials that are considered to be low-level waste. [DOE M 435.1-1, Attachment 2, item 25]

\section{B.4.2 Analysis}

As indicated above, depleted uranium in oxide and metal forms does not qualify as high-level waste, spent nuclear fuel, transuranic waste, or byproduct material, as defined by AEA $\S 11 \mathrm{e}(2)$. Therefore, since depleted uranium oxides and metal are radioactive materials, but would not be classified as any of the other types of radioactive wastes when disposed, they match the definition of low-level waste, and should be characterized as such for disposal.

\section{B.5 Conclusion}

Based on the above analyses, depleted uranium in the form of oxides or metal would be characterized as low-level waste for disposal. 


\section{APPENDIX C \\ Waste Acceptance Criteria}

\section{C.1 Hanford}

Excerpted from Hanford Site Solid Waste Acceptance Criteria, HNF-EP-0063, Rev. 5, Fluor Daniel Hanford, June 29, 1998.

\subsection{ACCEPTANCE CRITERIA FOR THE UNLINED PORTIONS OF THE LOW-LEVEL BURIAL GROUNDS}

The following criteria define baseline requirements to comply with the regulatory, permitting, safety, environmental, and operational requirements for the unlined portions of the LLBG. For criteria relating to the lined portions of the LLBG, refer to Chapter 4.0.

\subsection{Facility Description and Function}

The LLBG are a land disposal unit for controlled burial of low-level radioactive waste. The LLBG includes a number of unlined disposal trenches that accept only radioactive waste not regulated under 40 CFR 261, WAC 173-303, or 40 CFR 761 (TSCA PCB waste). The LLBG also include two disposal trenches (trenches 31 and 34) for disposal of mixed waste. This chapter relates only to the acceptance criteria for the unlined portions of LLBG. Acceptance criteria for trenches 31 and 34 are provided in Chapter 4.0.

\subsection{Prohibited Waste}

The following types of waste are not disposed in the unlined portions of the LLBG:

- Waste that is dangerous or extremely hazardous as defined by WAC 173-303, or as hazardous waste as defined by 40 CFR 261 (HNF-SD-EN-WAP-002)

- $\quad$ TSCA-regulated PCB waste (HNF-SD-EN-WAP-002)

- Waste generated from CERCLA cleanup activities, unless specific approval (e.g., a Record of Decision) has been granted by the EPA to manage the waste on the Hanford Site.

- Waste containing free liquids, except as allowed in Section 3.3.1 (HNF-SD-EN-WAP-002)

- Gaseous waste packaged at pressures exceeding 1.5 atmospheres (152 kilopascals absolute pressure) at $20^{\circ} \mathrm{C}\left(68^{\circ} \mathrm{F}\right)$ (DOE Order 5820.2A)

- Unstabilized organic liquids (including sorbed organic liquids) exceeding $1 \%$ of the waste by weight

- Unstabilized chelating compounds exceeding $1 \%$ of the waste by weight (DOE Order $\underline{\mathbf{5 8 2 0 . 2 A}})$

- Infectious waste

- Transuranic waste and waste that exceeds Class C, and other radiological limits of Section 3.4.1 
- Waste that might generate toxic gases, vapors, or fumes in concentrations that reasonably could be expected to exceed occupational exposure limits and/or air emission standards before disposal (DOE Order 5820.2A)

\subsection{Physical/Chemical Criteria}

The following are the physical/chemical criteria for acceptance of waste at the LLBG.

\subsubsection{Liquids and Liquid-Containing Waste}

All free liquids must be sorbed or stabilized in accordance with Appendix E, or otherwise removed from the waste, except as specifically allowed as follows (HNF-SD-EN-WAP-002).

- Containerized free liquids are allowed in the following situations, but cannot exceed $1 \%$ of the volume of the waste (HNF-SD-EN-WAP-002, DOE Order 5820.2A):

- Free liquids in a very small container, such as an ampule

- Small articles that contain free liquids required for the article to function

- For liquid-containing waste where condensate could form in inner plastic packaging (e.g., bags) subsequent to packaging, the condensate shall be eliminated to the maximum extent practical by placing sorbents within the inner plastic packaging (HNF-SD-EN-WAP-002). The type and amount of sorbent required shall be in accordance with Appendix E. In any case, the amount of liquid cannot exceed $1 \%$ of the volume of the waste or $0.5 \%$ of waste processed to a stable form (DOE Order 5820.2A).

- Residual liquids in large debris items shall be sorbed or removed. In cases where it is not practical to remove suspected liquids and it is impossible to sample to determine if liquids are present, the liquids shall be removed to the maximum extent possible by draining suspected liquids at low points and placing an adequate amount of sorbent around each item (HNF-SD-EN-WAP-002). In any case, the amount of liquid cannot exceed $1 \%$ of the volume of the waste (DOE Order 5820.2A).

\subsubsection{Land Disposal Restrictions}

Waste that is initially subject to regulation under RCRA can be disposed in the LLBG with a determination that the waste is no longer dangerous waste and the waste meets the applicable treatment standards of 40 CFR 268. These waste types include the following.

- Hazardous debris that is exempted from regulation under 40 CFR 261.3(f).

- Waste that originally was designated only with characteristic waste numbers D001 through D043 that is no longer hazardous, and that meets all of the applicable treatment standards of 40 CFR 268.

A copy of the applicable notification to the EPA Regional Administrator, as specified in 40 CFR 268.7, and data supporting this notification must be provided to the WMH acceptance organization. 3.3.3 Solidification or Stabilization of Organic Liquids and Chelating Compounds

Organic liquids and chelating compounds exceeding $1 \%$ of the waste by weight must be solidified or stabilized to a form that immobilizes the organic and chelating compounds (DOE Order 5820.2A). Selection and use of solidification and stabilization agents shall be in accordance with Appendix E. 3.3.4 Asbestos Containing Waste

Asbestos containing waste material shall be packaged in accordance with 40 CFR 61.150. Wetting with water is allowed as long as it does not exceed applicable free liquid requirements.

\subsubsection{Heat Generation}

If heat generation from radiological decay in the waste package exceeds 3.5 watts per cubic meter ( 0.1 watt per cubic foot), the package must be evaluated to ensure that the heat does not affect the 
integrity of the container or surrounding containers in the LLBG. This evaluation must be approved by the WMH acceptance organization.

\subsubsection{Gas Generation}

Gas generation from radiolytic or biological decomposition of containerized waste must be controlled to prevent pressurization exceeding 1.5 atmospheres (152 kilopascals absolute pressure), and combustible gas (e.g., hydrogen, methane) concentrations exceeding the lower explosive limit during handling before disposal. If a waste generates sufficient gas to exceed these limits, the following mitigating measures (or alternative measures approved by the WMH acceptance organization) must be used.

- Control of hydrogen from radiolytic decomposition: use a Nucfil 013는 filter or equivalent. All container liners and inner bags must be closed in a manner that allows gas to reach the vent filter (e.g., twist and tape method for bags). In addition to filtering, palladium or platinum catalyst packs could be used to control hydrogen concentrations in the container.

- Control of gases from biological decomposition: waste containing readily biodegradable organic materials (e.g., animal waste, vegetation) must be vented with a Nucfil $013_{-}^{\text {TM }}$ filter or equivalent. In addition, a mixture of $10 \%$ by weight slaked lime in $90 \%$ inorganic sorbent shall be added to the waste to reduce biological decomposition if filtering alone is not sufficient to control combustible gas concentrations.

- Packaging of animal carcasses: Radioactive animal carcasses must be packaged as follows (Ecology 1989).

- The waste must be packaged in an inner and outer metal package, where the outer package has a capacity at least 40 percent greater than that of the inner package. The outer package must be a metal container that meets applicable transportation requirements for shipment to the LLBG.

- The inner package shall be lined with a minimum 4 mil plastic liner. The animal carcass(es) in the inner package must be surrounded with a mixture of 10 parts mineral sorbent to 1 part slaked lime. The plastic liner and inner package must be sealed.

- A minimum of 7.6 centimeters ( 3 inches) of mineral sorbent must be placed in the bottom of the outer package, the inner package placed into the outer package, and the void space filled between the two packages with additional mineral sorbent.

- The outer package must be sealed.

\subsection{Radiological Criteria}

The following are the radiological criteria for acceptance of waste at the LLBG.

\subsubsection{Radiological Concentration Limits}

The methodology for classification of the radionuclide content of waste against the various limits listed in the following sections are provided in Appendix A. A waste must meet all of the following conditions to be disposed in the LLBG.

- TRU content limit - TRU content (as calculated by method A.1 of Appendix A) shall not exceed 100 nanocuries per gram of waste (DOE Order 5820.2A)

- Waste category (as calculated by methods A.4 and A.5 of Appendix A) shall not exceed Category 3, except with an analysis coordinated by the WMH acceptance organization demonstrating that the LLBG Performance Assessment conditions are met (WHC-EP-0645, WHC-SD-WM-TI-730). 
- Category 3 waste (as calculated by methods A.4 and A.5 of Appendix A) can be disposed of only if the waste meets one of the following waste form stability criteria (WHC-EP0645, WHC-SD-WM-TI-730).

- Packaging in a HIC that meets the testing requirements of the Hanford High Integrity Container, 300 Year specification (WHC-S-0486)

- Packaging in a HIC approved by the WMH acceptance organization. (Note: a list of approved $\underline{\text { HCs }}$ is available on the Hanford Site Solid Waste Acceptance Program Internet web page (http://www.hanford.gov/wastemgt/wac/index.htm).

- Stabilization in concrete or other stabilization agents. The stabilized waste must meet the leach index and compression strength criteria of the NRC Technical Position Paper on Waste Form, Section C.2 and Appendix A (NRC 1991).

- Inherently stable waste that meets the stability requirements of 10 CFR 61.56 and the NRC Technical Position Paper on Waste Form (NRC 1991).

- Mobile radionuclides - If the concentration of any mobile radionuclide exceeds the Mobile Radionuclide Reporting Limit of Appendix A, Table A-2, stabilization could be required (WHC-EP-0645, WHC-SD-WM-TI-730). WMH will perform a case-by-case evaluation against the LLBG performance assessment (WHC-EP-0645, WHC-SD-WM-TI-730) to determine whether the waste requires stabilization to meet the groundwater pathway dose criteria. Stabilization normally would consist of placement of the waste container in a HIC, but additional stabilization might be required based on a number of factors such as waste form and radionuclide content. The WMH acceptance organization will coordinate this evaluation.

- $\quad$ NRC Class C limit - Waste shall not exceed the NRC Class C limits (as calculated by method A.6 of Appendix A) (DOE Order 5820.2A).

- ISB limits - Waste must meet the applicable ISB limits for the LLBG (as calculated by method A.7 of Appendix A), with the following exception: if a combustible waste exceeds the combustible waste limit, but does not exceed the noncombustible waste limit, the WMH acceptance organization can coordinate an evaluation to determine whether segregation or stabilization can be used to mitigate the combustibility hazard (HNF-SD-WM-ISB-002).

\subsubsection{Criticality Safety Limits}

The limits for fissile and fissionable material are provided in Appendix B (CPS-SW-149-00003).

\subsubsection{Package External Contamination Limits}

Removable contamination on accessible surfaces of waste packages shall not exceed the limits of the Hanford Site Radiological Control Manual (HSRCM-1), Table 2-2.

\subsubsection{Package Dose Rate Limits}

Contact-handled waste shall not exceed 1 milliSievert per hour (100 millirem per hour) at 30 centimeters ( 1 foot) from the waste package and 2 milliSieverts per hour ( 200 millirem per hour) on the surface of the package, except that a package larger than 208 liters may have a marked point on the bottom or side with a surface dose rate of up to 10 milliSieverts per hour (1,000 millirem per hour) as long as the 30 centimeter dose rate limit is not exceeded (DOE Order 5820.2A, HSCRM$1)$.

Remote-handled waste shall meet the applicable dose rate restrictions of DOT or an approved packaging safety analysis. Remote-handled waste shall be configured for unloading such that personnel exposures are maintained as low as reasonably achievable (ALARA), and in no case shall exceed 100 millirem per hour exposure rate. 


\subsection{Packaging Criteria}

The following are the packaging criteria for acceptance at the LLBG.

\subsubsection{Outer Packages}

Outer packages that meet one of the following criteria will provide adequate containment for disposal.

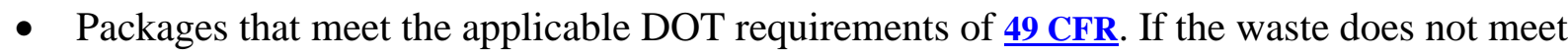
the definition of any DOT hazard class, a strong tight container is adequate.

- Packages that have been evaluated through an approved packaging safety analysis. Drums or boxes not exceeding 2.74 meters long by 1.6 meters wide by 1.7 meters high (nominally 9 feet long by 5.25 feet wide by 5.5 feet high) should be used whenever possible to facilitate receipt verification. When a larger container is required, the $\mathrm{WMH}$ acceptance organization must be notified before packaging.

\subsubsection{Package Construction}

All outer packages shall be nonflammable or constructed of fire-retardant materials. All exterior surfaces of wooden packages shall be treated with a fire-retardant material having a maximum flame-spread index of 25 when tested to ASTM Standard Test Method for Surface Burning Characteristics of Building Materials (ASTM E-84-96). Cardboard containers are not acceptable for disposal (DOE Order 5820.2A). Packages and sacrificial rigging shall not contain regulated materials, such as lead.

\subsubsection{Condition of Containers}

Outer containers shall be in good condition, with no visible cracks, holes, bulges, substantial corrosion, or other damage that could compromise integrity.

\subsubsection{Securing Waste and Shielding}

Large heavy items must be secured in containers by bracing, blocking, or other means to prevent damage to the container during handling and transportation. When shielding is used to reduce the surface dose rate of a waste container, the shielding and waste must be secured to prevent shifting during handling and transportation.

\subsubsection{Handling of Packages}

All packages must be configured for safe unloading by forklift or crane. Alternate means of unloading could be allowed with approval from the TSD unit manager or designee. Packages that must be unloaded by crane shall be equipped with a lifting system designed to safely lift the fully loaded package. All slings and lifting devices shall meet the requirements of the Hanford Site Rigging Manual (DOE-RL-92-36). For packages that have special unloading requirements, information must be provided to the WMH acceptance organization concerning the methods for unloading before the shipment is scheduled. Sacrificial rigging shall be provided for remotehandled waste packages. Rigging shall not contain regulated materials, such as lead.

\subsubsection{Minimization of Subsidence}

All waste shall be packaged in a form that minimizes settling and subsidence of the LLBG to the maximum extent feasible (DOE Order 5820.2A, WHC-EP-0645, WHC-SD-WM-TI-730). The following forms will be considered to meet these criteria.

- Inherently stable waste that will not subside in the disposal environment.

- Waste stabilized by grouting or packaging in a HIC.

- Containerized waste that fills at least $90 \%$ of the internal volume of the container. To calculate the volume of void spaces in the waste, only voids exceeding 5.1 centimeters ( 2 inches) in all dimensions need be considered. Any void fillers must be selected and used in accordance with Appendix E. 


\subsubsection{Labeling}

Waste containers shall be labeled in accordance with Appendix C. Bulk waste and remote-handled waste containers that are removed from reusable overpacks are exempt from labeling requirements at the LLBG. For unusual waste forms, special labeling provisions can be arranged with the WMH acceptance organization.

\subsubsection{Bulk (Noncontainerized) Waste}

Certain types of waste can be disposed in bulk rather than packaging in containers. This includes soil, vegetation, building rubble, and other homogeneous waste having relatively low concentrations of radionuclides and hazardous chemical constituents. The Solid Waste Burial Grounds Interim Safety Basis (HNF-SD-WM-ISB-002) identifies the radiological and chemical conditions under which bulk waste may be disposed. To avoid unnecessary conservatism, universally applicable limits have not been developed for the LLBG acceptance criteria. Instead, a case-by-case evaluation will be performed on request to determine whether a given waste stream can be disposed in bulk, including any mitigating measures required to meet the conditions of the ISB. 


\section{C.2 Nevada Test Site}

Excerpted from Nevada Test Site Waste Acceptance Criteria, DOE/NV-325, Rev. 1, August 1997.

\subsection{Waste Criteria}

Waste accepted at the NTS must be radioactive and meet the waste form criteria outlined below. ${ }^{6.13}$ These requirements facilitate handling and provide health and safety protection for personnel at the disposal site. Waste streams not meeting these basic requirements will be evaluated individually (see Section 3.7).

\subsection{General Waste Form Criteria}

These waste form criteria are based on current DOE LLW management policies and practices.

\subsubsection{Transuranics}

The concentration of alpha-emitting transuranic nuclides with half-lives greater than 20 years $\boldsymbol{m u s t}$ not exceed $100 \mathrm{nCi} / \mathrm{g} .{ }^{6.8}$ The net weight of the waste (excluding the weight of the container and shielding) must be used to calculate the specific activity of the waste in each container. ${ }^{6.7}$ The following isotopes shall ${ }^{6.6}$ be considered when making the TRU waste determination: ${ }^{236} \mathrm{~Np},{ }^{237} \mathrm{~Np}$, ${ }^{238} \mathrm{Pu},{ }^{239} \mathrm{Pu},{ }^{240} \mathrm{Pu},{ }^{242} \mathrm{Pu},{ }^{244} \mathrm{Pu},{ }^{241} \mathrm{Am},{ }^{242} \mathrm{Am},{ }^{243} \mathrm{Am},{ }^{243} \mathrm{Cm},{ }^{245} \mathrm{Cm},{ }^{246} \mathrm{Cm},{ }^{247} \mathrm{Cm},{ }^{248} \mathrm{Cm},{ }^{250} \mathrm{Cm}$, ${ }^{247} \mathrm{Bk},{ }^{249} \mathrm{Cf}$, and ${ }^{251} \mathrm{Cf}$.

\subsubsection{Hazardous Waste}

LLW offered for disposal must not exhibit characteristics of, or be listed as, hazardous waste as identified in Title 40 CFR, state of Nevada regulations, or state-of-generation hazardous waste

regulations. ${ }^{3.4 / 5.6}$ State of Nevada regulations require that waste regulated as hazardous in the state of generation must be regulated as hazardous when brought into the state of Nevada. ${ }^{5.5}$

\subsubsection{Free Liquids}

Wastes containing free liquids must be converted into a form that contains as little freestanding and noncorrosive liquid as is reasonably achievable. ${ }^{6.22}$ Liquid wastes should be solidified or packaged in sufficient absorbent to absorb twice the volume of the liquid, but liquid must not exceed 1 percent of the volume of the waste when the waste is in a disposal container; or 0.5 percent of the volume of the waste processed in stable form. ${ }^{1.1 / 6.22}$

Please note when significant temperature differences exist between the generating site and the disposal site, provisions for additional absorbent materials should be made.

\subsubsection{Particulates}

Fine particulate wastes shall be immobilized so that the waste package contains no more than 1 weight percent of less-than-10-micrometer-diameter particles, or 15 weight percent of less-than200-micrometer-diameter particles. ${ }^{7.6}$ Waste that is known to be in a fine particulate form or in a form that could mechanically or chemically be transformed to a particulate during handling and interim storage must be immobilized. ${ }^{7.6}$ 
Secure packaging may be used in place of immobilization. Examples of acceptable packaging are: overpacking (i.e., 55-gallon drum inside 85-gallon drum); steel box, and drums and wooden boxes with a minimum of a sealed 6-mil plastic liner, unless the contents are individually wrapped and sealed in plastic.

\subsubsection{Gases}

LLW gases must be packaged at a pressure that does not exceed 1.5 atmospheres at $20^{\circ} \mathrm{C} .{ }^{6.25 / 7.6}$ Compressed gases as defined by Title 49 CFR shall not be accepted. ${ }^{4.7 / 6.25}$ Examples of compliance methods include puncturing aerosol cans and removing the valve mechanism from expended gas cylinders.

\subsubsection{Stabilization}

Where practical, waste must be treated to reduce volume and provide a more stable waste form. ${ }^{6.19}$ Wastes must not react with the packaging during storage, shipping, handling, and disposal. ${ }^{6.17}$

3.1.6.1 Structural stability can be accomplished by crushing, shredding, or placing a smaller piece inside an opening of a larger piece, such as nesting pipes.

3.1.6.2 Chemical stability and compatibility must be demonstrated to ensure no reactions occur and significate quantities of harmful gases, vapors, or liquids are not generated. ${ }^{6.16 / 6.24}$ Specifically when different waste forms are combined in a single waste container.

\subsubsection{Etiologic Agents}

LLW containing pathogens, infectious wastes, or other etiologic agents as defined in Title 49 CFR shall not be accepted. ${ }^{1.3}$

\subsubsection{Chelating Agents}

LLW packages containing unbound (free) chelating or complexing agents which mobilize

radionuclides shall not be accepted greater than 1 percent by weight of the waste form..$^{6.18 / 7.6}$

\subsubsection{Polychlorinated Biphenyls (PCBs)}

PCB-contaminated LLW shall not be accepted for disposal unless the PCB concentration meets municipal solid waste disposal levels of 50 ppm. ${ }^{3.16 / 5.1}$ Refer to Title 40 CFR, state of Nevada, and state-of-generation regulations for PCB disposal requirements.

\subsubsection{Explosives}

Waste must not be readily capable of detonation or of explosive decomposition or reaction at normal pressures and temperatures, or of explosive reaction with water. ${ }^{6.23}$

\subsubsection{Pyrophorics}

Waste must not be pyrophoric. ${ }^{6.26}$ Pyrophoric materials contained in the waste shall be treated, prepared, and packaged to be nonflammable. ${ }^{6.26}$ Pyrophoric materials that are. treated, prepared, and packaged to be nonflammable. ${ }^{2.26}$ Pyrophoric materials that are blended in a hardened concrete matrix are considered to be treated to be nonflammable. 


\subsubsection{Sealed Sources}

Sealed sources shall be segregated from other waste and handled as a separate waste stream. ${ }^{7.3}$ Sealed sources shall be characterized on an individual source basis. ${ }^{7.3}$

Sources which contain TRU nuclides shall be evaluated against the TRU waste criteria individually, considering only the mass of the source itself (no packaging, extrinsic shielding, or other waste-diluting materials) ${ }^{7 \cdot 3}$ If the source is encapsulated for physical integrity or uniformly distributed throughout a media such as plastic or soil, the capsule or other matrix may be utilized as part of the mass for TRU waste calculations (assuming the source was originally manufactured in this configuration). Concentration averaging over integral components of a sealed source is acceptable.

\subsubsection{Low-Level Waste Containing Asbestos}

Asbestiform Low-Level Waste (ALLW) is defined as any LLW containing Regulated AsbestosContaining Material (RACM). ALLW must be packaged, marked, and labeled in accordance with the requirements of Title 40 CFR, state of Nevada, state of generation, and the NTS Management Plan for the Disposal of Low-Level Waste with Regulated Asbestos Waste, dated August 1996 or subsuquent revisions. ${ }^{3.1 / 5.2}$ Packages containing ALLW must meet the applicable shipping requirements for the radioactive contents of the package. ${ }^{4.6} \mathrm{ALLW}$ that is friable or otherwise capable of giving off friable asbestos dust must be wetted and packaged in a plastic bag which is not less than 6 mils in thickness, a combination of plastic bags which equal at least 6 mils in thickness, or a container which is lined with plastic. ${ }^{5.3}$

If free liquid is present, absorbent must be added to ensure compliance with the free-liquids criteria. ${ }^{6.22}$ Sharp edges and corners in the package must be padded or protected to prevent damage to the plastic bag during handling, shipping, and disposal. ${ }^{7.6}$

Each container used to dispose of ALLW must bear a label that contains one of the following statements: ${ }^{5.4}$

(1) CAUTION

CONTAINS ASBESTOS FIBERS

AVOID OPENING OR BREAKING CONTAINER

BREATHING ASBESTOS IS HAZARDOUS TO YOUR HEALTH

(2) CAUTION

CONTAINS ASBESTOS FIBERS

AVOID CREATING DUST

MAY CAUSE SERIOUS BODILY

HARM

(3) DANGER

CONTAINS ASBESTOS FIBERS

AVOID CREATING DUST

CANCER AND LUNG DISEASE

HAZARD. 
ALLW must be segregated into a separate waste stream. ${ }^{7.9}$ Due to state notification requirements and disposal cell capacity, ALLW must be packaged separately from other waste streams. ${ }^{5.27 .6}$ The NTS Management Plan for disposal of ALLW includes specific requirements for preshipment notification. Call DOE/NV WMD at (702) 295-3181 for assistance and a copy of the current NTS Management Plan.

\subsubsection{Radioactive Animal Carcasses}

Animal carcasses containing, or contained in, radioactive materials shall be packaged with the biological material layered with lime and placed in a metal container meeting applicable requirements. ${ }^{1.2 / 1.3}$ If the resultant waste matrix is capable of gas generation, the container shall be vented with a carbon composite High-Efficiency Particulate Air (HEPA)-rated filtration device. ${ }^{1.2 / 7.6} \mathrm{DOE} / \mathrm{NV}$ may require analysis of the waste decomposition gases. Animal carcasses preserved with formaldehyde shall not be accepted for disposal. ${ }^{3.5}$

\subsection{Waste Package Criteria}

Waste packages must meet applicable DOE Orders, 10 CFR, 40 CFR, and 49 CFR requirements such as: design, nuclear safety, radiation levels, external contamination, activity limits, nuclear heating, and multiple hazards.

DOE/NV has adopted the following waste package criteria to assure that the NTS RWMSs are operated safely and efficiently.

\subsubsection{Nuclear Criticality Safety}

The quantity of fissile radioactive materials shall be limited so that an infinite array of such packages will remain subcritical. ${ }^{6.2}$ This quantity shall be determined on the basis of a specific nuclear safety analysis, considering credible accident situations, and taking into account the actual materials in the waste. ${ }^{6.1}$

\subsubsection{Closure}

The package closure must be sturdy enough that it will not be breached under normal handling conditions. ${ }^{4.10}$

\subsubsection{Strength}

The disposal package (packaging and contents) must be capable of supporting a uniformly distributed load of $16,477 \mathrm{~kg} / \mathrm{m}^{2}\left(3,375 \mathrm{lbs} / \mathrm{ft}^{2}\right){ }^{7.4}$ This is required to support other waste packages and earth cover without crushing during stacking and covering operations. Actual physical testing or design engineering calculations can be used to demonstrate this requirement. This section does not apply to bulk waste, waste packaged in steel drums, or SEALAND ${ }^{\circledR}$ containers.

\subsubsection{Handling}

Waste packages $\boldsymbol{m u s t}$ be provided with cleats, offsets, rings, handles, permanently attached or removable skids, or other auxiliary lifting devices to allow handling by means of forklifts, cranes, or similar handling equipment. ${ }^{7.6}$ Removable skids are preferred to assist in meeting NTS PA objectives for reducing disposal cell subsidence. Lifting rings and other auxiliary lifting devices on the package are permissible, provided they are recessed, offset, or hinged in a manner that does not inhibit stacking the packages. The lifting devices must be designed to a 5:1 safety factor based on 
the ultimate strength of the material. ${ }^{7.1}$ All rigging devices that are not permanently attached to the waste package must have a current load test based on 125 percent of the safe working load..$^{2.1 / 2.2}$

Handling procedures and ALARA documentation must be referenced on the WP for wastes requiring remote handling. ${ }^{7.6}$ The disposal site may request this documentation. Packages exceeding $200 \mathrm{mR} / \mathrm{hr}$ dose rate on contact are usually considered for remote handling.

\subsubsection{Size}

1.2- $\times 1.2-\times 2.1-\mathrm{m}(4-\times 4-\times 7-\mathrm{ft})$ or $1.2-\times 0.6-\times 2.1-\mathrm{m}(4-\times 2-\times 7-\mathrm{ft})$ boxes $($ width $\times$ height $\times$ length, plus or minus $1 / 2$ inch) or 208 -liter (55-gallon) drums should be used. These sizes allow optimum stacking efficiency in disposal cells. Alternate packages (i.e., supersacks, burrito wraps) will be considered; however, RWMS operations personnel need to be consulted to ensure equipment compatibility.

Bulk waste generally exists in a form not suited to the conventional packaging requirements. Bulk LLW must meet the requirements of Title 49 CFR.4.11 Large items of bulk waste, such as machinery, may be considered for disposal unpackaged. For the transfer of unpackaged bulk material having external contamination, the contamination must be fixed, covered, or contained sufficiently for safe transfer. ${ }^{4.12}$

Bulk waste shipping containers may be returned to the generator after decontamination. Decontamination and return of bulk waste shipping containers will incur additional operational costs for the generator.

\subsubsection{Weight}

In addition to the weight limits for specific packaging designs, packages shall not exceed 4,082 $\mathrm{kg}$ (9,000 pounds) per box and $544 \mathrm{~kg}$ (1,200 pounds) per drum. ${ }^{2.3}$ This weight limit does not apply to bulk waste.

\subsubsection{Loading (Void Space)}

Waste packages must be loaded to ensure that the interior volume is as efficiently and compactly loaded as practical to minimize void space. ${ }^{6.21}$ More than one waste stream may be packaged in a disposal container (See Appendix C and D). High-density loading will allow efficient RWMS space utilization and provide a more stable waste form that will reduce subsidence and enhance the long-term performance of the disposal site.

\subsubsection{Package Protection}

The following are precautions to protect the waste package after closure.

Once the package certification activities have been completed, the preshipment storage environment should be controlled to prevent package deterioration.

In-process packages must have controls to prevent intrusion. ${ }^{7.5}$ After package certification activities have been completed, the waste container must be secured. ${ }^{7.5}$ Package security would ensure that the package has not been breached after certification. Packages with features such as tamper 
indicating devices, clips, or banding that are not readily breakable and that, while intact, demonstrate that the package has not been opened will satisfy this requirement.

\subsubsection{Marking and Labeling}

Each waste package must be marked and labeled according to Appendix C. ${ }^{4.2}$

\subsubsection{Bar Coding}

The shipment and package numbers must be bar coded according to the standards in Appendix C. ${ }^{7.6}$

\subsection{Radionuclide Reporting}

Reportable radionuclides shall be reported on the WP and Package Storage and Disposal Request (PSDR). ${ }^{6.10 / 7.5}$ The WP is applied at a waste stream level. The PSDR is applied at a waste package level. Any radionuclides reported on the PSDR must also be identified on the WP. ${ }^{7.5}$ (See Appendices B and D for examples of WP and PSDR.)

\subsubsection{Reportable Radionuclides}

Radionuclides known or reasonably expected to be present in a waste stream meeting the following criteria shall be reported. ${ }^{6.9 / 6.10 / 6.15}$

3.3.1.1 The activity concentration in the final waste form exceeds one percent of the Action Level (Table E-1). ${ }^{6.15 / 7.9}$ These radionuclides should require the most rigorous waste characterization.

3.3.1.2 The activity concentration in the final waste form exceeds one percent of the total activity concentration. ${ }^{6.15 / 7.9}$ The total activity concentration shall include the activity of all radionuclides except for those that are exempt form the reporting requirements as specified in Section 3.3.2. ${ }^{6.15 / 7.9}$ For these radionuclides and for those present at a level less than the detection limit of industry accepted characterization methods, Process Knowledge (PK) should be sufficient for characterization.

\subsubsection{Exempt Radionuclides}

Radionuclides meeting any of the following criteria are exempt from the reporting requirements:

3.3.2.1 Any radionuclide, as listed in Table E-2 (see page E-3), that will reach a state of transient or secular equilibrium with a parent radionuclide within the operational period of the disposal site.

3.3.2.2 Any radionuclide occurring at activity concentrations not exceeding background ranges for the region in which it was generated and material of interest.

\subsection{Greater-than-Class C Waste}

Commercial waste designated as Greater-than-Class C (GTCC), as defined in 10CFR 61.55 and DOE waste that, if commercially generated, would meet the GTCC definition, may be evaluated for disposal on a case-by-case basis depending on site-specific waste classification limits. This review may involve considering non-routine disposal options (i.e., controlling depth of disposal, 
considering other waste forms and package integrity, limiting the other types of wastes disposed nearby) or the development of a specific radiological performance assessment. 


\section{C.3 Barnwell}

The radioactive material license issued by the state of South Carolina for the Barnwell facility contains the waste acceptance criteria applied to potential waste forms for disposal. The following is taken from the radioactive material license (Barnwell Disposal Facility Radioactive Material License (Disposal), SCDHEC License Number 097, available on-line at http://www.chemnuclear.com/requests.htm

Waste Characteristics and Waste Form Conditions

31. The licensee shall not accept any radioactive waste for storage or disposal unless the shipper has marked each disposal container, as specified by the licensee, to identify its classification as either Class A, stable or unstable (S or U), Class B, or Class C waste, and certifies that the waste materials have been classified and prepared in accordance with the following waste classification table:

Waste Classification Table

\section{RADIONUCLIDES CONCENTRATION LIMITS IN CURIES/CUBIC METER*}

Table I (long-lived) Class A Class B Class C

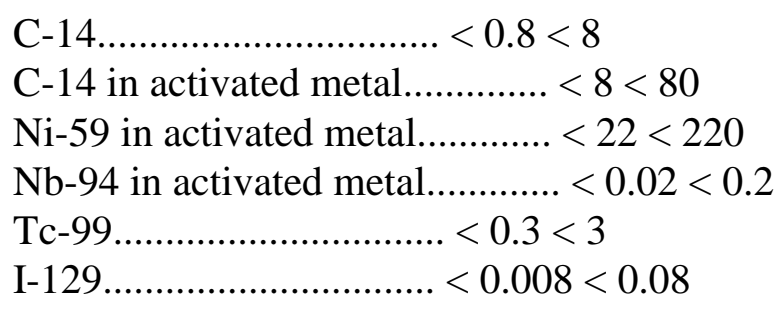

CONCENTRATION LIMITS IN

\section{NANOCURIES/GRAM}

Alpha emitting transuranics with half-life greater than 5 years... $<10<100$

Ra-226....................... $<10<100$

$\mathrm{Pu}-241 \ldots \ldots \ldots \ldots \ldots \ldots . . . . . . . . . . . .<350<3500$

$\mathrm{Cm}-242 \ldots \ldots \ldots \ldots \ldots \ldots \ldots . . . . . . . . . . . .<2000<20000$

\section{CONCENTRATION LIMITS IN}

CURIES/CUBIC METER*

Table II (short-lived) Class A Class B Class C 
Total of all with half-life less

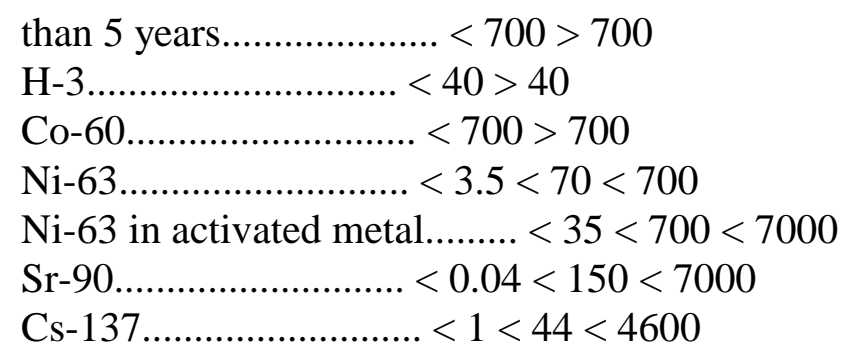

*curies/cubic meter is equivalent to microcuries/cubic centimeter

A. The concentration of a radionuclide or radionuclide mixture may be averaged over the volume of the waste and, if used, the solidification agent or matrix if the waste form is a homogenous mixture. The concentration of radionuclides in filters/sealed sources encapsulated with a solidification agent or matrix shall be averaged over the volume of the filter/sealed source not the solidification agent. The volume of packaging, containers, liners, or overpacks shall not be included in this calculation, nor shall the volume of the waste mixture be artificially increased with the addition of non-dispersible solids or objects even if considered as waste.

If expressed in units of nanocuries per gram, concentration may be averaged over the weight of the waste and, if used, the solidification agent if homogenous, except in the case of encapsulation of filters which shall be over the weight of the filter. The weight of packaging, containers, liners, or overpacks shall not be included in this calculation, nor shall the weight of the waste mixture be artificially increased by the addition of heavy, non-dispersible solids or objects even if considered as waste.

B. The waste is Class A if none of the listed radionuclides are present.

C. There are no upper limits in Class B waste for the first three radionuclides listed in Table II.

D. There are no Class B values for the first nine (9) radionuclides listed; their presence classifies the waste as either Class $\mathrm{A}$ or Class $\mathrm{C}$ according to their concentrations.

E. The waste class for mixtures of radionuclides is determined by deriving for each radionuclide the ratio between its concentration in the mixture and its concentration limit in the table and adding the resulting ratio values for each radionuclide group. All limits used in the calculation must be for the same waste class. The sum of the ratios for each group must be less than or equal to 1.0 or the waste is of a higher classification than that used for the calculation.

F. If Class $\mathrm{C}$ limits are used in the calculation and the sum of the ratios for either group is equal to or exceeds 1.0, the waste is not acceptable for disposal without prior written approval from the Department.

G. If the concentration of any single radionuclide exceeds Class $\mathrm{C}$ values in the table, the waste is not acceptable for disposal without prior written approval from the Department. 
H. Concentrations for C-14, Ni-59, Ni-63, and Nb-94 in activated metal must be evaluated for any irradiated metal component, filters and filter material associated with spent fuel pools.

I. Waste containing radium may be accepted only if the requirements of condition 44 of this license are met.

32. A. Unless otherwise specified in this license, the licensee shall not receive any liquid radioactive waste regardless of the chemical or physical form. Absorbent materials may be placed in packages of dry, solid waste to absorb unintentional and incidental amounts of liquids. Further, liquids in the interstitial spaces of transport casks and containers shall be removed to the extent practical.

B. Solidified or dewatered radioactive waste shall have no detectable free standing liquids in excess of one-half percent $(0.5 \%)$ by waste volume of non-corrosive liquids per container.

C. In lieu of the requirements of paragraph B. above, solidified or dewatered waste containing noncorrosive liquids in excess of one-half percent $(0.5 \%)$ by waste volume, and less than on percent (1\%) non-corrosive liquids by waste volume, may be received and disposed of in high integrity containers approved by the Department.

33. A. Unless otherwise specified, the licensee shall only receive aqueous liquids and other applicable waste forms which have been solidified or otherwise stabilized with one of the following solidification media:

a. Vinyl Ester Styrene

b. Cement

c. Bitumen (see Subparagraph E. below)

d. Vinyl Chloride

B. Solidification media and processes used to stabilize Class A aqueous liquids and other Class A wastes containing isotopes with greater than five (5) year half-lives having a total specific activity if all these isotopes of 1 microcurie/ cubic centimeter or greater, and all applicable Class B and C waste, shall meet and have been evaluated in accordance with the "Stability Guidance" requirements of the U.S. Nuclear Regulatory Commission's Waste Management Division, Technical Position on Waste Form, (Revision 1), dated January 1991, or other evaluation criteria or methods specifically approved by the NRC or the Department.

C. Solidified Class A aqueous liquids and other applicable waste forms with a specific activity of less than 1 microcurie/cubic centimeter, shall meet the requirements of the "Solidified Class A Waste Products" of the NRC Technical Position on Waste Form, (Revision 1) dated January 1991.

D. Other solidification media and processes shall be acceptable for which a topical report has been prepared and received approval from the U.S. Nuclear Regulatory Commission with concurrence from the Department or approval by the Department. 
E. The licensee shall only receive for disposal, full formula, oxidized bitumen (asphalt) solidified waste, which is a free standing monolith as received for disposal, and certified as such by the waste generator.

34. Except as specifically provided in this license, the licensee shall not accept liquid radioactive waste packaged in absorbent materials, or where absorbent materials have been used to absorb liquids rather than properly solidified with an approved media.

35. Regardless of the waste classification of Condition 31, and unless otherwise authorized by the Department, the licensee shall not receive evaporator bottoms or concentrates, residues, sludges, or other waste which may contain free standing liquids, unless they are solidified in accordance with Condition 33, and meet the requirements as specified in Condition 32. Evaporator bottoms or concentrates which contain no free standing water and are not free flowing are acceptable for disposal when processed by a method specifically approved by the Department.

36. The licensee may receive resins and filter media in a dewatered form provided that the free standing liquid requirements of Condition 32 and the requirements of Condition 38 are met.

37. The licensee shall not receive containers of ion exchange resins or filter media (dewatered or solidified) unless records of complete radiological analyses (quantitative and qualitative) are provided. The records must specify the specific activity of each radionuclide expressed in microcuries/cubic centimeter and transuranic radionuclides in nanocuries/gram.

38. Regardless of the waste classification of Condition 31, ion exchange resins and filter media containing isotopes with greater than five (5) year half-lives having a specific activity of all these isotopes of 1 microcurie/cubic centimeter or greater must be stabilized by solidification in accordance with Condition 33 and meet the free standing liquid requirements of Condition 32.B. However, in lieu of solidification, the Department will authorize disposal of these waste forms meeting the free standing liquid requirements of Condition 32.C. in approved high integrity containers or other approved methods of stabilization.

39. Unless specifically provided otherwise, the licensee shall dispose of all classes of wastes in concrete overpacks or vaults which are approved by the Department and provided by the site operator. Void spaces within the waste and between the waste and its packaging shall be reduced to the extent practicable, but in no case shall less than eighty-five percent (85\%) of the capacity of the containers be filled for all waste classes unless placed in a High Integrity Container. The licensee may allow a variance from this condition in certain instances, but only after receiving a written justification from the waste generator prior to receiving the waste shipment. Variance justifications and approvals shall be maintained for review by the Department.

40. Radioactive waste containing transuranic radionuclides within the limits specified in Condition 31 are acceptable provided that the transuranic radionuclides are evenly distributed within a homogeneous waste form and are incidental to the total radioactivity. Incidental in this condition is defined as not more than one percent $(1 \%)$ of the total activity. This license does not authorize the receipt of disposal of components or equipment primarily contaminated with transuranic 
radionuclides on vehicles, equipment, or components, with contamination limits in excess of those specified in Condition 55.

41. Household or industrial smoke or gas detectors containing Americium-241 foils which may exceed the transuranic radionuclide limit specified in Condition 31 of this license may be accepted for disposal provided the entire detector is received for disposal.

42. The licensee shall not receive or dispose of sealed sources or special form radioactive materials containing more than 5 curies of radioactive material with half-lives greater than 5 years except in a container which provides long term containment. Such containers are subject to approval by the Department. Irradiated metal components which have similar characteristics of special form radioactive materials are subject to Department review for disposal container requirements.

The licensee may accept the following sealed sources and maximum total activities provided that the sources are encapsulated with a minimum of four (4) inches of cement on all sides having a minimum compressive strength of 2,500 pounds per square inch.

Radionuclide Maximum Total Activity

(microcuries)

C-14 100

$\mathrm{Ni}-59100$

$\mathrm{Nb}-940.01$

Tc-99 10

I-129 0.01

Radionuclides

in Condition 31. Table II 107

43. The licensee shall not receive toluene, xylene, dioxane, scintillation liquids which exhibit hazardous properties or other organic liquids or solids with similar chemical properties except as specified below:

A. Containers which have contained any of the liquids mentioned above are acceptable for disposal after treatment as specifically authorized by the Department.

B. The ash and/or residue from the incineration of these wastes are acceptable in accordance with Condition 45 of this license.

44. Unless otherwise authorized by the Department the licensee shall not receive any radioactive waste containing Radium except for:

A. Radium contained in solid homogeneous waste forms in which the Radium activity is incidental (incidental is defined as not more that one percent of the total activity) and the concentration of Radium has not been technologically enhanced or, 
B. Radium contained in the following devices: self-luminous dials, hands of dials, timepieces, compasses, and electron tubes provided that the entire device is received and buried, or

C. Radium contained in biological research waste, or

D. Radium sources specifically approved by the Department.

45. The licensee shall not receive radioactive waste in the forms of incinerator ash or powder which may be dispersible unless solidified with a media specified in Condition 33 of this license, or packaged to prevent dispersion as specifically approved by the Department. In lieu of solidification, these waste forms may be received in high integrity containers approved by the Department, provided the waste is rendered nondispersable with a binding matrix.

46. Radioactive waste containing chelating agents between 0.1 percent and 8 percent by weight in the waste as received for disposal shall be in High Integrity Containers or shall be stabilized by solidification with a media specified in Condition 33 of this license or an alternative method specifically approved by the Department.

47. The licensee may only receive gaseous radioactive materials of Krypton 85, Xenon 133, and Tritium for burial provided they meet the following criteria:

\section{A. For Krypton 85 and Xenon 133:}

a. Burial containers must be U.S. Department of Transportation specification cylinders or U.S. Nuclear Regulatory Commission approved sealed sources.

b. Internal pressure of containers may not exceed 1.5 atmospheres.

c. Total activity of containers shall not exceed 100 curies each.

B. For Tritium:

a. Only sources approved by the U.S. Nuclear Regulatory Commission or an Agreement State may be received for disposal.

b. The source/device must be received intact.

c. The internal pressure of the source/device shall not exceed 1.5 atmospheres.

d. Sources/devices must be packaged to prevent breakage.

e. The maximum activity per disposal container shall not exceed 1000 curies.

f. Devices requiring stabilization based on waste classification (using the volume of the source/device only) must be placed in a high integrity container or encapsulated with an appropriate stabilization media. 
48. A. Unless otherwise authorized, the licensee shall not receive for storage nor disposal any mixed low-level radioactive waste defined as waste that satisfies the definition of low-level radioactive waste specified in the Low-Level Radioactive Waste Policy Amendments Act of 1985 (P.L. 99-240), and contains waste that either (1) is listed as hazardous waste in Subpart D, 40 CFR 261 , or (2) causes the waste to exhibit any of the hazardous waste characteristics identified in Subpart C, 40 CFR Part 261.

B. The licensee may however receive waste that has been treated by acceptable methods to render it nonhazardous and therefore not subject to the jurisdiction of the Resource Conservation and Recovery Act (RCRA). Waste which may contain discrete quantities of hazardous or toxic materials may be evaluated for disposal by the licensee and such evaluations provided to the Department for consideration of approval.

49. The licensee shall not receive radioactive waste that is readily capable of detonation or of explosive decomposition or reaction at normal pressures and temperature, or of explosive or exothermic reaction with water.

50. The licensee shall not receive radioactive waste which contains or is capable of generating quantities of toxic gases, vapors, or fumes harmful to persons transporting, handling or disposing of the waste. This does not apply to radioactive gaseous waste packaged in accordance with Condition 47 of this license.

51. The license shall not receive or dispose of any pyrophoric material or flammable solids. These materials contained in waste shall be treated, prepared and packaged to be nonflammable and the final waste form rendered nonpyrophoric and nonflammable prior to transportation and receipt.

52. The licensee shall not receive or bury oil or petroleum based materials in any physical form. However, this does not prohibit the receipt and disposal of waste containing incidental or trace amounts of oil or petroleum based materials which have been absorbed, provided that the amount of absorbed oil and petroleum based materials does not exceed one percent (1\%) by waste volume in a container.

53. The licensee shall not receive radioactive waste containing hazardous biological, pathogenic, or infectious material unless treated to reduce to maximum extent practicable the potential hazard from the materials. In addition, radioactive waste containing biological, pathogenic, or infectious material shall be doubly packaged in new or properly recertified containers which meet the general packaging requirements of DOT as follows:

A. First, the inner container having a capacity of 55-gallon or less shall have a water tight liner at least 4 mils thick hermetically sealed after filling.

B. The biological material shall be thoroughly layered in the inner container in a ratio of thirty (30) parts biological material to at least one (1) part slaked lime and ten (10) parts absorbent, which shall be agricultural grade 4 vermiculite or medium grade diatomaceous earth, or other adsorbents that have received approval from the Department by volume. The addition of formaldehyde is strictly prohibited. 
C. The closure on the inner container shall be a standard lid with securely attached ring and bolt. Lever locks are not acceptable.

D. Unless otherwise authorized by the Department, the outer container, which shall have a volume of at least 1.5 times the inner container shall be filled initially with at least 4 inches of absorbent material, specified in B., the inner container in an upright position, and the remaining volume filled with the absorbent material, then securely closed and properly sealed.

54. Unless otherwise authorized by the Department, the licensee shall receive Special Nuclear Material (SNM) as authorized in Conditions 5, 6, 7, and 8 of this license in 55 gallon or larger containers only. Any SNM shipment in which there is evidence that SNM is missing or that the waste packages have been tampered with in transport shall be received by the licensee and safely stored pending notification to the Department. The licensee shall not dispose of such packages unless authorized by the Department. 


\section{C.4 Waste Control Specialists}

Excerpted from the WCS waste acceptance criteria document, Rev. 0, issued 9/3/98 by their Radiation Safety Department. Available on-line at: http://www.wcstexas.com/html/wcs_wac.html

\section{Section 1 - Purpose and Scope}

These Radioactive Waste Acceptance Criteria establish the basis for acceptance of low-level and mixed radioactive waste materials at the Waste Control Specialists, LLC (WCS) Andrews Facility in Andrews County, Texas. The following types of radioactive waste may be accepted at the WCS facility for processing and interim storage, and, in some cases, disposal at exempt levels:

Low-Level RadioactiveWaste (LLRW). Radioactive waste material not classified as high-level waste, spent nuclear fuel, transuranic (TRU) waste, uranium mill tailings, or mixed waste. LLRW can include byproduct, source, and special nuclear material, natural occurring and accelerator produced radioactive material (NARM), or sealed sources.

Mixed Waste (MW). LLRW containing both radioactive and hazardous or toxic components as defined by the Atomic Energy Act (AEA), the Resource Conservation and Recovery Act (RCRA), and the Toxic Substances Control Act (TSCA). Non-AEA radioactive material mixed with RCRA or TSCA waste can also be accepted at WCS.

Natural Occurring Radioactive Material (NORM). Radioactive material resulting from natural sources that contain any nuclide that is radioactive in its natural physical state (i.e., not manmade). This includes NORM which may have been technologically enhanced (the chemical properties or physical state of natural sources of radiation have been altered or the potential exposure pathways to humans have been altered).

Source material. Uranium or thorium, or any combination thereof, in any physical or chemical form; or ores that contain by weight $0.05 \%$ or more of uranium, thorium, or any combination thereof.

Special Nuclear Materials (SNM). Fissionable radioactive material in quantities not sufficient to form a critical mass as defined in TRCR Part 11.2.

Non-radioactive hazardous waste (regulated under RCRA and TSCA) can also be accepted from approved generators for processing, storage and disposal at the WCS Facility; however, the criteria and procedures for acceptance of non radioactive hazardous waste is not within the scope of this document. Contact the Facility Manager at 1-888-789-2783 for additional information.

For questions regarding this waste acceptance criteria document or any other questions regarding WCS radioactive waste management capabilities, contact William Dornsife (Vice President - Nuclear Affairs) at 888-492-7552 or 717540-5220 or other designated WCS staff at 1-888-789-2783.

These criteria have been established to ensure that State of Texas, U.S. Department of Transportation (DOT), U.S. Nuclear Regulatory Commission (NRC), U.S. Environmental Protection Agency (EPA) and local government requirements are met, and to satisfy operational requirements at the WCS facility.

\section{Section 2 - Procedures for Shipping Waste to the WCS Andrews Facility}

The WCS waste acceptance criteria, characterization, and certification requirements apply to all generators and waste collectors shipping radioactive waste to the WCS Andrews Facility. All packages will be evaluated for compliance with the acceptance criteria, and any additional requirements established by WCS and its regulators. Waste may not be shipped to the WCS Facility until the shipment has been authorized by WCS. The steps involved in this process include:

1. Contact the WCS Nuclear Department at 1-888-492-7552, to discuss contract and pricing topics.

2. Submit a waste profile sheet to WCS providing information about the generator, the waste to be shipped, and assurances that the requirements in this document will be satisfied. This waste profile (Appendix A attached) must be submitted for WCS approval prior to shipment of waste.

3. WCS will review this information, may conduct generator/broker site visits as needed to verify characterization and certification processes, and approve or reject the generator/collectors radioactive waste based on the information submitted and provide an authorization to ship letter.

4. Shipment should be scheduled at least 72 hours before arrival at the site with at 1-888-789-2783. 


\section{Section 3 - Radioactive and Mixed Waste Acceptance Criteria}

This section identifies acceptance criteria for contaminant levels, waste packaging and form restrictions for all radioactive and mixed waste accepted at the WCS facility for processing, interim storage, disposal, and for waste resulting from WCS processing operations.

\section{1 - General Packaging and Waste Form Acceptance Criteria for All Radioactive and Mixed Waste}

1. Waste packages will not be accepted at the WCS facility without the generator and shipper's certification that the shipment has been packaged, loaded, and transported in accordance with all applicable provisions of USDOT regulations in 49 CFR Parts 170-178 and USNRC regulations in 10 CFR 71. Applicable State of Texas regulations for waste receipt, notification, labeling and manifesting include Texas Regulations for Control of Radiation (TRCR) Part11 and TRCR Part 21, Appendices D and E.

2. Mixed waste (MW) shall meet applicable USDOT and USEPA regulatory requirements for the hazardous and/or toxic components in addition to meeting regulatory requirements for radioactive materials. Limited quantity MW must be classified according to requirements for hazardous material as defined by Title 49 CFR 173.2.

3. Waste containing multiple hazards shall be packaged according to the level of hazard as defined in Title 49 CFR 173.2, "Classification of Material Having More than One Hazard." Incompatible MW shall be packaged in accordance with Title 40 CFR 264.177, "Special Requirements for Incompatible Wastes." Incompatible wastes may not be packaged together.

4. Waste packages shall be provided with lifting devices. Acceptable devices include pallets, skids, cleats, offsets, rings, handles, or other auxiliary lifting devices to allow handling by means of forklifts, cranes, or similar handling equipment. Lifting rings and other auxiliary lifting devices on the package are permissible, provided they are recessed, offset, or hinged in a manner that does not inhibit stacking the packages or they may be sheared/destroyed during transfer by WCS. The lifting devices must be designed to a 5:1 safety factor based on the ultimate strength of the material. All rigging devices that are not permanently attached to the waste package must have a current load test based on 125 percent of the safe working load. This does not apply to shipments of bulk material.

5. All DOT packages should include a closure device that is sturdy enough so that it will not be breached under normal handling conditions and will not serve as a weak point for package failure.

6. All waste packages shall be loaded as efficiently and compactly as practical to maximize utilization of interior volume. With the agreement of the generator, WCS can consolidate and repackage waste that is not optimally loaded prior to placing into interim storage.

7. Waste containing pathogens, infectious wastes, explosives, organic peroxide, or other etiologic agents as defined in Title 49 CFR 173.386 will not be accepted.

8. The generator shall take the following precautions to protect the waste package after closure prior to shipment:

- The preshipment storage environment shall be controlled to avoid adverse influence from weather or other factors on the containment capability of the waste packaging during handling, storage, and transport. The generator preparing waste in preshipment storage shall preclude the accumulation of moisture on or in packages prior to their arrival at the WCS facility.

- A form of Tamper Indicating Device (TID) shall be applied to each container once certification actions have been completed.

- Each waste package shall be prepared for shipment so as to minimize damage during transit. Damage or contamination incurred during transit will be the responsibility of the generator, and will have to be suitably repaired prior to acceptance.

- The requirements of Title 40 CFR 264, Subpart I, "Use and Management of Containers," shall be met for all MW packages.

\section{2 - Radionuclide Acceptance Criteria for Exempt Level Radioactive Material Disposal at WCS}

Disposal may require NRC or Agreement State approval if the material has been licensed under the Atomic Energy Act. Contact William Dornsife (Vice President Nuclear Affairs) at 717-540-5220 or 888-492-7552 for details and assistance.

1. Source material (uranium or thorium) in any physical or chemical form, solution or alloy in which the source material is $<0.05 \%$ by weight. This translates to the following concentrations: Th- $232=54.5 \mathrm{pCi} / \mathrm{g}, \mathrm{U}-238=$ $166.5 \mathrm{pCi} / \mathrm{g}, \mathrm{U}($ nat $)=355 \mathrm{pCi} / \mathrm{g}, \mathrm{Th}($ nat $)=110 \mathrm{pCi} / \mathrm{g}$, and $\mathrm{U}($ depleted $)=250 \mathrm{pCi} / \mathrm{g}$.

2. Unrefined or unprocessed ores containing source material (U or Th).

3. Rare earth metals, compounds, mixtures, or products containing less than $0.25 \%$ by weight $\mathrm{Th}$ or $\mathrm{U}$ or any combination thereof.

4. Any finished product, part, or scrap containing metal thorium alloys with $\mathrm{Th}<4 \%$ by weight. 
5. Depleted U in counterweights installed in aircraft, rockets, projectiles, or missiles or used as a shielding material constituting part of any shipping container.

6. Self luminous products containing $\mathrm{H}^{3}, \mathrm{Kr}^{85}, \mathrm{Pr}^{147}$ manufactured under a specific license which authorizes the transfer to exempt persons.

7. Any other specific items exempted from licensing under TRCR Part 40.3 or 40.4 .

8. Naturally Occurring Radioactive Materials (NORM) containing any NORM radionuclide less than $150 \mathrm{pCi} / \mathrm{gm}$ (this includes any Uranium and Thorium radionuclides if not licensed or classified by the generator as source material) or technologically enhanced radium 226 or radium 228 at less than $30 \mathrm{pCi} / \mathrm{gm}$, averaged over any 100 square meters in the first 15 centimeters of soil below the surface, provided the radon emanation rate is less than 20 picocuries per square meter per second. If containerized, the average concentration for the shipment must meet these same limits.

3.3 Additional packaging and waste form acceptance criteria for disposal of radioactive and mixed waste at WCS 1. Wastes shall not be packaged for disposal in cardboard or fiberboard boxes.

2. Liquid waste shall be packaged in sufficient absorbent material to absorb twice the volume of the liquid.

3. Solid waste containing liquid shall contain as little free-standing and non-corrosive liquid as is reasonably achievable, but in no case shall the liquid exceed 1 percent of the volume.

4. Waste shall not be readily capable of detonation or of explosive decomposition or reaction at normal pressures and temperatures, or of explosive reaction with water.

5. Waste shall not contain, or be capable of generating, quantities of toxic gases, vapors, or fumes harmful to persons transporting, handling, or disposing of the waste.

6. Waste must not be pyrophoric. Pyrophoric materials contained in wastes shall be treated, prepared, and packaged to be nonflammable.

7. Wastes in a gaseous form shall be packaged at an absolute pressure that does not exceed 1.5 atmospheres at $20^{\circ} \mathrm{C}$. Total activity shall not exceed 100 curies (3.7 terabecquerels) per container. 8. Wastes containing biological, pathogenic, or infectious material shall be treated to reduce to the maximum extent practicable the potential hazard from the non-radiological materials.

9. Waste containing hazardous or toxic substances must be treated in accordance with all applicable State of Texas and USEPA requirements prior to disposal. WCS can perform these necessary treatment services as described in Section 3.9.

\subsection{Acceptance Criteria for Interim Storage of LLRW at WCS}

LLRW classified as Class A, B, C, or greater than C can be accepted for interim storage at WCS. NORM, TRU, sealed sources, and mixed waste will also be accepted on a case by case basis for interim storage. All LLRW must meet all of the criteria in Section 3.1 and 3.3 as well as the following to be accepted for interim storage at WCS. License inventory limits for various radionuclides are shown in Table 2.

1. Packages: All waste for interim storage shall be shipped in USDOT approved packages. Preferred containers include the following: $4 \times 4 \times 7 \mathrm{ft}(1.2 \times 1.2 \times 2.1-\mathrm{m})$ or $4 \times 2 \times 7 \mathrm{ft}(1.2 \times 0.6 \times 2.1 \mathrm{~m})$ (WHL) boxes, 55-gallon (208-liter) drums, 85 gallon overpacks, B-25 boxes, and 195/215 liners. Other dimensions may be pre-approved by the WCS Facility Manager. Cardboard or fiberboard boxes will not be accepted for interim storage.

2. Strength: Except for bulk waste, waste packaged in steel drums, or SEALANDTM containers, the waste package (packaging and contents) shall be capable of supporting a uniformly distributed load of $4,000 \mathrm{lbs} / \mathrm{ft} 2(19528 \mathrm{~kg} / \mathrm{rn} 2)$. This is required to support other waste packages during stacking operations.

3. LLRW accepted for storage at WCS's Facility shall not exhibit any characteristics of, or be listed as, hazardous waste as identified in Title 40 CFR 261 "Identification and Listing of Hazardous Waste." For information on hazardous waste storage services, contact the facility manager.

4. LLRW shall contain no free-standing or corrosive liquids. Waste containing liquids shall be processed to solidify the liquid using a sufficient quantity of absorbent materials to contain twice the volume of the liquid.

5. LLRW containing discrete radium ( $>2 \mathrm{nCi} / \mathrm{gm}$ ) shall be in the form of sealed sources and packaged in a $2 \mathrm{R}$ container, or its equivalent. The $2 \mathrm{R}$ container must be immobilized in concrete in the center of a second container. The second container must be a DOT approved container.

6. Compressed gases as defined by Title 49 CFR 173.300, including unpunctured aerosol cans, will not be accepted for interim storage at the WCS facility. 
7. Where practical, LLRW shall be treated to reduce volume and provide a high degree of physically and chemically stability. Wastes shall not significantly react with the packaging during normal storage, shipping, and handling. Void spaces within the waste and between waste and its package shall be minimized to the extent practicable.

8. Waste containing chelating or complexing agents at concentrations greater than eight percent by weight will not be accepted at the WCS facility without special WCS approval.

9. Waste must be received in a form that meets all acceptance criteria for interim storage or can be treated by WCS to achieve an acceptable waste form. 


\section{C.5 Envirocare}

Copied from Waste Acceptance Guidelines, Rev. 1, Envirocare of Utah, Inc., 46 West Broadway, Suite 116, Salt Lake City, UT, July 28, 1999.

The Envirocare WAC is not available in electronic format suitable for inclusion in this report. Hardcopies of this report have Section 3 (Acceptable Waste Materials), pp. 11-23, attached.

A pdf version of the Envirocare WAC is available at: http://www.envirocareutah.com/pages/wac/index.html 


\section{APPENDIX D}

\section{DOE Agreements with Ohio and Tennessee}

\section{D.1 Agreement With Ohio}

The Ohio Environmental Protection Agency (Ohio EPA), to which the EPA has delegated authority to implement the Resource Conservation and Recovery Act (RCRA) within Ohio, issued a notice of violation (NOV) in 1992, which declared that depleted $\mathrm{UF}_{6}$ being stored at the DOE Portsmouth Gaseous Diffusion Plant is "waste," as defined by the Ohio Administrative Code (OAC) [OAC §3745-51-02]. "Waste," under the OAC, must be characterized to determine if it is "hazardous waste." Therefore, the NOV reasoned that because the depleted $\mathrm{UF}_{6}$ stored at the Portsmouth Plant is "waste," DOE is violating OAC $\$ 3745-52-11$ by not evaluating whether the depleted $\mathrm{UF}_{6}$ being stored at the Portsmouth plant is hazardous waste.

In 1998, DOE and the Ohio EPA reached a settlement regarding management of the depleted $\mathrm{UF}_{6}$ at the Portsmouth Plant. The settlement took the form of an agreed order, which was entered into the Ohio EPA Director's Journal and became effective on February 24, 1998. [Ohio EPA 1998]. The agreed order sets aside disagreements over whether the depleted $\mathrm{UF}_{6}$ stored at the Portsmouth Plant constitutes source material (as maintained by DOE) or is a waste that requires characterization (as argued by Ohio EPA). In fact, the order expressly reserves the respective positions of both parties, and exempts DOE for a specified time from the requirement to evaluate whether depleted $\mathrm{UF}_{6}$ stored at the Portsmouth Plant is hazardous waste. ${ }^{1}$ The exemption is contingent on DOE complying with a depleted $\mathrm{UF}_{6}$ Management Plan and making good faith efforts to evaluate potential use or reuse of the $\mathrm{UF}_{6}$. The exemption expires when any of the following events occurs:

- Depleted $\mathrm{UF}_{6}$ is no longer stored at the Portsmouth Plant.

- Ten years pass from February 24, 1998.

- DOE evaluates whether depleted $\mathrm{UF}_{6}$ is a hazardous waste.

- The Ohio EPA revokes the exemption.

If the exemption expires before DOE stops storing depleted $\mathrm{UF}_{6}$ at the Portsmouth Plant, DOE may end up evaluating whether depleted $\mathrm{UF}_{6}$ is a hazardous waste in Ohio. For this reason, section D.3, below, discusses how regulatory requirements applicable to disposal of depleted uranium oxides and metal generated by conversion of depleted $\mathrm{UF}_{6}$ would be affected if depleted $\mathrm{UF}_{6}$ were hazardous waste in Ohio. In no way, however, does inclusion of section D.3 in this report imply that DOE accepts the notion that depleted uranium in any form stored at a DOE site is subject to RCRA.

${ }^{1}$ ORC $\$ 3734.02(\mathrm{G})$ allows the Director of Ohio EPA to exempt by order any person generating, storing, treating, transporting, or disposing of hazardous waste in such quantities or under such circumstances determined by the Director as unlikely to adversely affect public health or safety or the environment, from any requirement to obtain a registration certificate, permit, or license or comply with the manifest system or other requirements of the solid and hazardous waste laws of Ohio. 


\section{D.2 Agreement with Tennessee}

In July 1998, the Tennessee Department of Environment and Conservation (TDEC), to which the EPA has delegated authority to implement RCRA within Tennessee, communicated a draft RCRA NOV to DOE. According to the draft, DOE's failure to determine whether depleted $\mathrm{UF}_{6}$ stored at the East Tennessee Technology Park (ETTP) (formerly the Oak Ridge K-25 Gaseous Diffusion Plant) is hazardous waste violates Tennessee solid and hazardous waste laws and regulations. To resolve this and other matters, DOE signed an agreement with TDEC on February 2, 1999. In the agreement, DOE promised to manage depleted, enriched, and natural $\mathrm{UF}_{6}$ cylinders stored at the ETTP in accordance with a specified management plan. The management plan makes it an enforceable provision of the Order that DOE must issue a Record of Decision (ROD) by July 31, 1999 for the final Programmatic Environmental Impact Statement (PEIS) for Alternative Strategies for the Long-Term Management and Use of Depleted Uranium Hexafluoride. Further, unless the ROD selects the no action alternative, DOE must either move all known depleted $\mathrm{UF}_{6}$ cylinders off the ETTP site, or convert the depleted $\mathrm{UF}_{6}$ to another form by December 31, 2009. Unlike the Ohio Order described above, the Tennessee Order does not mention characterizing depleted $\mathrm{UF}_{6}$ to determine whether it is hazardous waste under RCRA.

\section{D.3 Disposal of Depleted Uranium in Ohio if Depleted UF 6 is Hazardous Waste}

As previously stated, this section discusses how regulatory requirements applicable to disposal of depleted uranium oxides and metal generated by conversion of depleted $\mathrm{UF}_{6}$ would be affected if depleted $\mathrm{UF}_{6}$ is hazardous waste in Ohio. The discussion provides information for decision-making purposes only. In no way does including this section in the report imply that DOE accepts the notion that depleted uranium in any form stored at a DOE site is subject to RCRA.

Since the Ohio hazardous waste regulations do not list depleted $\mathrm{UF}_{6}$ as a hazardous waste (see OAC $\S \S 3745-51-30$ through 3745-51-33) and the Ohio EPA does not claim it to be mixed waste, evaluating whether depleted $\mathrm{UF}_{6}$ is hazardous waste in Ohio would involve determining whether depleted $\mathrm{UF}_{6}$ exhibits any of the four hazardous waste characteristics (i.e., ignitability, corrosivity, reactivity, and toxicity, as defined in OAC $\S \S 3745-51-21$ through $3745-51-24)$. A waste containing more than 0.5 percent filterable solids exhibits the toxicity characteristic if an extract from a representative sample of the waste is obtained using the Toxicity Characteristic Leaching Procedure (TCLP), (EPA 1986, as amended) and the extract contains one or more of the contaminants listed on table 1 in OAC $\$ 3745-51-24^{1}$ at concentrations equal to or greater than the respective values on table

\footnotetext{
${ }^{1}$ Contaminants listed on table 1 in OAC $\$ 3745-51-24$ are: arsenic; barium; benzene; cadmium; carbon tetrachloride; chlordane; chlorobenzene; chloroform; chromium; o-cresol; m-cresol; p-cresol; cresol; 2,4-D; 1,4-dichlorobenzene; 1,2-dichloroethane; 1,1-dichloroethylene; 2,4-dinitrotoluene; endrin; heptachlor (and its epoxide); hexachlorobenzene; hexachlorobutadiene; hexachloroethane; lead; lindane; mercury; methoxychlor; methyl ethyl ketone; nitrobenzene; pentrachlorophenol; pyridine; selenium; silver; tetrachloroethylene; toxaphene; trichloroethylene; $2,4,5$ trichlorophenol; 2,4,6-trichlorophenol; 2,4,5-TP (silvex); and vinyl chloride.
} 
1. It is unlikely that depleted $\mathrm{UF}_{6}$ in DOE's inventory would exhibit the RCRA toxicity characteristic defined in OAC $\$ 3745-51-24$. DOE's depleted $\mathrm{UF}_{6}$ does not contain, or have as derivatives, any of the contaminants listed on table 1 in OAC $\$ 3745-51-24$. Therefore, to be hazardous waste in Ohio, depleted $\mathrm{UF}_{6}$ would have to exhibit one of the other three hazardous waste characteristics.

Presently, insufficient information is available to predict the possible outcome of evaluating whether depleted $\mathrm{UF}_{6}$ may exhibit ignitability, corrosivity, or reactivity. However, for this discussion, it is unnecessary to make such a prediction. Instead, this section conservatively assumes that depleted $\mathrm{UF}_{6}$, if evaluated, would display at least one of these hazardous waste characteristics.

If depleted $\mathrm{UF}_{6}$ were found to be ignitable, reactive, or corrosive, in Ohio, depleted $\mathrm{UF}_{6}$ storage, transportation, and conversion would be subject to Ohio hazardous waste regulations. In addition, direct disposal in Ohio of depleted uranium oxide or metal generated by conversion of $\mathrm{UF}_{6}$, (whether or not the conversion occurred in Ohio) would be subject to the Ohio hazardous waste regulations. Ohio regulations governing disposal in Ohio of depleted uranium oxides or metal from converting depleted $\mathrm{UF}_{6}$ that is hazardous waste are summarized below. The requirements governing storage, transportation, and conversion of depleted uranium that is hazardous waste in Ohio is beyond the scope of this report.

It should be noted that even if depleted $\mathrm{UF}_{6}$ were determined to be hazardous waste in Ohio, it would not necessarily be hazardous waste in other States. Hence, if depleted $\mathrm{UF}_{6}$ becomes hazardous waste in Ohio, the requirements discussed below would apply only to disposal of $\mathrm{UF}_{6}$ conversion products in Ohio. Requirements applicable to disposal in other states would depend on whether depleted $\mathrm{UF}_{6}$ would be hazardous waste under the laws and regulations of such other states.

When a waste to be disposed in Ohio exhibits the hazardous characteristic of ignitability, corrosivity, or reactivity at its point of generation, it must be treated to meet the applicable treatment standard under the Ohio land disposal restrictions (LDR) program. Currently, such standards are specified in 40 CFR $\$ 268.40$, rather than in the Ohio hazardous waste regulations. ${ }^{1}$ EPA has determined that wastes exhibiting the hazardous characteristics of ignitability, reactivity, and corrosivity may contain "underlying hazardous constituents" (UHCs). The UHCs for a particular ignitable, reactive, or corrosive waste are constituents for which a universal treatment standard (UTS) has been established (see 40 CFR \$268.48) and which are reasonably expected to be present at the point of generation in concentrations above UTS levels (except fluoride, selenium, sulfides, vanadium, and zinc). The federal LDR treatment standards for reactive and corrosive hazardous wastes are identical, and consist of removing the hazardous characteristic, plus additional treatment, if necessary,

$1 \quad$ OAC $\$ \S 3745-59-40$ to $3745-59-44$ specify the LDR treatment standards that have been adopted by the Ohio EPA. However, the existing Ohio LDR treatment standards for ignitable, corrosive, and reactive hazardous wastes are different from and are less stringent than the Federal LDR treatment standards for ignitable, reactive, and corrosive wastes. When more stringent Federal LDR treatment standards are adopted by EPA pursuant to the Hazardous and Solid Waste Amendments of 1984 (HSWA) [Pub. L. 98-616, November 8, 1984], in an authorized State, the Federal standards are implemented by EPA (or the authorized State under an agreement with EPA) unless and until the State adopts them. 
to reduce UHCs to UTS levels. [40 CFR 268.40] The federal LDR treatment standard for ignitable wastes is similar to the treatment standards for reactive and corrosive wastes. The only difference is that ignitable wastes also have the option of using combustion or organic recovery technologies. The Ohio EPA is required to adopt the more stringent federal LDR treatment standards.

Once treated residues for an ignitable, reactive, or corrosive waste meet the applicable LDR treatment standard, land disposal is allowed in any appropriate licensed disposal facility, provided that LDR notification and certification requirements are met. [OAC \$3745-59-09(D)] It is not required that the disposal facility meets the RCRA requirements for design and operation of a hazardous waste landfill.

Little information is currently available concerning whether converting depleted $\mathrm{UF}_{6}$ either to uranium oxides or to metal would remove ignitability, corrosivity, or reactivity (assuming that depleted $\mathrm{UF}_{6}$ exhibits one of these characteristics in the first place). Nevertheless, an examination of the chemical and physical characteristics of depleted uranium oxides suggests that they would not exhibit ignitability, corrosivity, or reactivity (see Section 2). For this reason, it seems reasonable to assume that converting depleted $\mathrm{UF}_{6}$ to uranium oxides would deactivate the depleted $\mathrm{UF}_{6}$ as required by $\mathrm{LDR}$ treatment standards. However, to comply fully with the LDR treatment standard for an ignitable, reactive or corrosive waste, UHCs (e.g., fluorine [Davis and Wang 1999]), which may be present in the uranium oxides, also must be below the UTS. ${ }^{1}$ If UHCs in the as-produced uranium oxides would not be below the UTS, then the uranium oxides would require treatment to reduce UHC concentrations further. The UTS for fluorine in nonwastewaters is $3.4 \mathrm{mg} / \mathrm{kg}$. It should be noted, however, that some physical forms of uranium metal might not achieve the "deactivation" requirement in the LDR treatment standard for ignitable, reactive, and corrosive wastes.

If a conversion process is used that would meet the applicable treatment standard in Ohio, then the conversion residue (depleted uranium oxides or metal) could be disposed in any appropriate nonhazardous waste disposal facility. Such a landfill would have to comply with applicable requirements for land disposal of radioactive materials, but would not be governed by requirements applicable to hazardous or mixed waste landfills.

${ }^{1}$ If residual fluorine in uranium oxides occurs in fluoride form, then it would not be an UHC. Fluorides are excluded from the list of UHCs for characteristic hazardous wastes (40 CFR 268.2(i)). 


\section{References for Appendix D}

Davis, G.D. and J. Wang, 1999, “An Integrated Solution for Long-Term Management of Depleted Uranium Hexafluoride," presented at NEI Fuel Cycle 99, Austin Texas (11- 14 April) (reporting that conversion of depleted UF6 to depleted U3O8 may leave fluorine in the oxide at levels ranging from $300 \mathrm{ppm}(6.8 \mathrm{mg} / \mathrm{kg})$ to $700 \mathrm{ppm}(15.8 \mathrm{mg} / \mathrm{kg})$ soluble fluorine $)$.

Ohio Environmental Protection Agency, 1998, Director's Final Findings and Orders in the Matter of United States Department of Energy Portsmouth Gaseous Diffusion Plant, February 24. 


\section{INTERNAL DISTRIBUTION}

\author{
1. J. M. Begovich \\ 2. J. B. Clendenen \\ 3. A. G. Croff \\ 4. W. K. Duerksen \\ 5. J. J. Ferrada \\ 6-10. J. R. Hightower, Jr. \\ 11. H. Wayne Hayden \\ 12. G. T. Mays
}

$\begin{array}{ll}\text { 13. } & \text { G. E. Michaels } \\ \text { 14. } & \text { D. W. Lee } \\ \text { 15. } & \text { R. L. Reid } \\ \text { 16. } & \text { J. R. Trabalka } \\ \text { 17. } & \text { K. A. Williams } \\ \text { 18. } & \text { Central Research Library } \\ \text { 19. } & \text { ORNL Laboratory Records-RC } \\ \text { 20. } & \text { ORNL Laboratory Records-OSTI }\end{array}$

\section{EXTERNAL DISTRIBUTION}

21. H. I. Avci, Environmental Assessment Division, EA 900 C29, Argonne National Laboratory, 9700 South Cass Avenue, Argonne, IL 60439

22. G. W. Benedict, DOE, Oak Ridge Operations Office, 200 Administration Road, Oak Ridge, TN 37831

23. N. P. Buschman, U.S. Department of Energy, Office of Depleted Uranium Hexafluoride, NE-30, Room E-469, 19901 Germantown Road, Germantown, MD 20874-1290

24. B. M. Biwer, Environmental Assessment Division, Argonne National Laboratory, EA 900 C10, 9700 South Cass Avenue, Argonne, IL 60439

25-29. J. R. Gasper, Environmental Assessment Division, Argonne National Laboratory, Suite 6000, 955 L'Enfant Plaza S.W., Washington, DC 20024

30. M. S. Goldberg, Environmental Assessment Division, Argonne National Laboratory, Suite 6000, 955 L'Enfant Plaza S.W., Washington, DC 20024

31. R. M. Knipp, U.S. Department of Energy, Immediate Office of the Director, NE-1, Room 5A157, 1000 Independence Avenue, S.W., Washington, DC 20585

32. S. R. Martin, DOE, Oak Ridge Operations, P.O. Box 2008, Oak Ridge, TN 37831-6269

33. N. L. Ranek, Environmental Assessment Division, Argonne National Laboratory, Suite 6000, 955 L'Enfant Plaza S.W., Washington, DC 20024

34. Robert R. Price, U.S. Department of Energy, Office of Depleted Uranium Hexafluoride, NE-30, Room E-461, 19901 Germantown Road, Germantown, MD 20874-1290

35. P. I. Stumbo, DOE, Oak Ridge Operations Office, 200 Administration Road, Oak Ridge, TN 37831

36. A. F. Tavares, U.S. Department of Energy, Office of Depleted Uranium Hexafluoride, NE-30, Room 1I-062, 1000 Independence Avenue, S.W., Washington, DC 20585

37. D. K. Wierville, DOE, Oak Ridge Operations Office, Room G 126-3, Federal Office Building, 200 Administration Road, Oak Ridge, TN 37831 